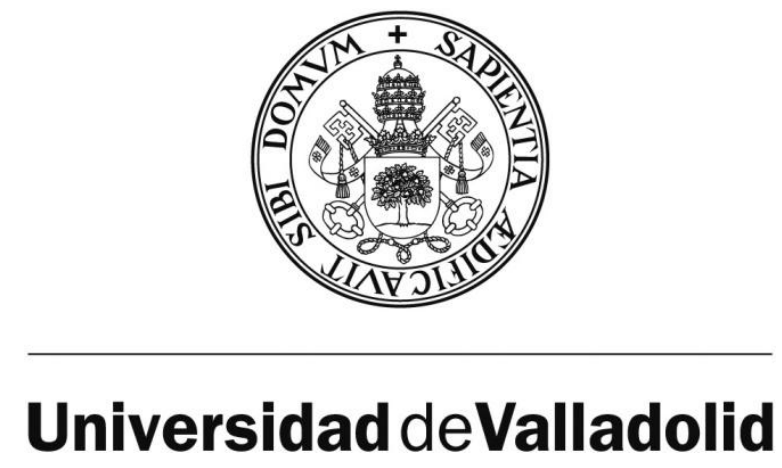

\author{
FACULTAD DE FILOSOFÍA Y LETRAS
}

Filología francesa y alemana

\title{
TESIS DOCTORAL: \\ ESTUDIO TEMÁTICO DEL AMOR Y LA GUERRA EN EL ROMAN D'ENÉAS Y EL ROMAN DE TROIE: DEL MODELO CLÁSICO AL TEXTO MEDIEVAL.
}

Presentada por Cristina Suárez Vega para optar al grado de

Doctora por la Universidad de Valladolid

Dirigida por:

Catherine Desprès-Caubrière 
"A todos aquellos que han hecho posible esta Tesis Doctoral" 


\section{AGRADECIMIENTOS:}

Quiero mostrar mi agradecimiento a todos aquellos que de una manera u otra han contribuido a realizar esta Tesis Doctoral y, especialmente, a Catherine DesprèsCaubrière, mi Directora, por haberme ofrecido la posibilidad de trabajar con ella y por su inmensa paciencia a la hora de realizar las correcciones, a Francine Mora por su esfuerzo desinteresado, su apoyo y su confianza. 


\section{INTRODUCCIÓN}

Este trabajo de investigación tiene como propósito el análisis de dos temas tradicionales en la literatura medieval francesa, como son el amor y la guerra; ambos temas esenciales en dos obras literarias fundamentales en la historia de la literatura francesa, consideradas como los ancestros del género novelesco. Se trata de dos textos del siglo XII: Enéas y Troie, que forman parte de lo que se ha denominado novela o trilogía antigua: traducciones/adaptaciones de obras de la Antigüedad clásica elaboradas en la segunda mitad del siglo XII, constituida por el Roman de Thèbes, de autor anónimo y que se inspira de la Tebaida de Estacio, el Roman d'Enéas, de autor también anónimo que toma como modelo clásico la Eneida de Virgilio y el Roman de Troie, cuyo autor Benoît de Sainte-Maure, expone en los primeros versos de su novela sus dos fuentes: De excidio Trojae de Dares Frigio y Ephemeris belli de Dictis Cretense, ambos autores, testigos presenciales de la guerra de Troya. En cuanto a la datación de las obras objeto de nuestro estudio, nos hemos guiado por la efectuada por E. Faral 1 , que sitúa a Enéas hacia el año 1150 y a Troie entre los años 1165 y 1170.

Los textos que he escogido para realizar el estudio son los siguientes: en cuanto al Roman d'Enéas, la edición de J. J. Salverda de $\mathrm{Grave}_{2}$ que reproduce el manuscrito A considerado como el más fiel al original. Para el Roman de Troie la edición que he utilizado es la de Emmanuèle Baumgartner y Françoise Vielliard 3 , que toma como base el manuscrito D55 de la Bibliothèque ambrosienne de Milán (M2), el más antiguo de los manuscritos completos del Roman de Troie.

Una vez establecido y delimitado el corpus, se fija el objetivo de este trabajo en un estudio comparativo que pretende ofrecer un examen de los dos temas seleccionados

1. Faral, E., Recherches sur les sources latines des contes et romans courtois du Moyen Âge, Genève, Slatkine Reprints, 1983, p. $169-187$.

2. Salverda de Grave, J.J., Enéas roman du XIIe siècle, París, Librairie Honoré Champion, 1973.

3. Sainte-Maure, B., Le roman de Troie, Paris, Librairie Générale Française, 1998. 
por su presencia relevante en ambas obras: el amor y la guerra. Para articular mi línea de trabajo, he estructurado el estudio en tres partes: un primer capítulo centrado en las tramas amorosas presentes en ambas novelas, en las que se analiza la pervivencia de elementos mitológicos. Un segundo capítulo dedicado al análisis comparativo, con relación al tema de la guerra, de Enéas y Troie y sus fuentes clásicas, y un tercer capítulo en el que se aborda el tratamiento del amor y la guerra a través de las miniaturas del manuscrito $\mathrm{BN}$ fr 60 datado del siglo XIV y conservado en la BNF de Paris, que recoge las dos novelas estudiadas. Tengo que decir que la línea de este último capítulo surge de un estudio realizado por la investigadora Laurence Harf-Lancner, leído y estudiado en el contexto de una beca de investigación concedida por la universidad de Valladolid, durante los meses de mayo, junio y julio del 2013 en el laboratorio ESR de la Universidad de Saint-Quentin-en-Yvelines, que me ha dado la posibilidad de consultar el manuscrito donde se encuentran las miniaturas estudiadas. El contacto directo con el manuscrito me ha permitido desarrollar un estudio personal ya que he adaptado su temática general a la selección de un corpus de miniaturas, en aras de completar y finalizar el estudio llevado a cabo en los dos capítulos precedentes.

Desde el punto de vista metodológico, me he basado en métodos comparativos, descriptivos y cuantitativos. Para la contextualización de las obras y su época he utilizado, libros de autores como Badel, P.Y, Introduction à la vie littéraire du Moyen Age $_{5}$, o Le Goff, J., La civilisation de l'Occident médiéval 6 . Para el estudio específico de la novela antigua hemos contado con los libros de Huchet, J-Ch, Le roman médiéval 7 , y Petit, A., L'anachronisme dans les romans antiques $d u$ XII siècle 8.

También, aparte de las obras de consulta que me han ayudado a plantear la metodología de este trabajo, para consolidar el marco teórico del estudio, especialmente

\footnotetext{
4. Harf-Lancner, Laurence, «L'élaboration d'un cycle romanesque antique au XIIe siècle et sa mise en images: Le roman de Thèbes, Le roman de Troie et le Roman d'Énéas dans le manuscrit $\mathrm{BN}$ français 60 », Le monde du roman grec. Actes du colloque international tenu à l'École normale supérieure, Paris 17-19 décembre 1987, éd. Marie-Françoise Baslez, Philippe Hoffmann et Monique Trédé, Paris, Presses de l'École normale supérieure (Études de littérature ancienne, 4), 1992, p. 291-306.

5. Badel, P.Y, Introduction à la vie littéraire du Moyen Age, Paris, Bordas, 1984.

6. Le Goff, J., La civilisation de l'Occident médiéval, Paris, Arthaud, 1977.

7. Huchet J-Ch, Le roman médiéval, Paris, Presses Universitaires de France, 1984.

8. Petit, A., L'anachronisme dans les romans antiques du XII siècle, Paris, Honoré Champion, 2002.
} 
el del primer capítulo, he recurrido a lecturas específicas que me han guiado en cuanto a la presencia de elementos mitológicos dentro del corpus estudiado. Por ello me parece importante incluir en esta introducción un resumen de las consideraciones sobre el mito y su transmisión en la literatura, y más concretamente en la literatura medieval, que he aplicado directamente a lo largo de un trabajo dedicado a textos en los que aflora la pervivencia de los mitos.

\section{APROXIMACIÓN DEFINITORIA DEL MITO}

La definición literaria de mitología medieval aborda el mito como "un conjunto de elementos textuales transmitidos por la tradición y puestos en la literatura con fines culturales9". Una de las definiciones más extendidas es la que ofrece Mircea Eliade, que concibe el mito como "una historia sagrada, es decir, un acontecimiento primordial que tuvo lugar en el comienzo del Tiempo, ab initio. El mito es, pues, la historia de lo acontecido in illo tempore, el relato de lo que los dioses o los seres divinos hicieron al principio del tiempo 10 ". Estas dos definiciones bastan para exponer las características fundamentales del relato mitológico, así como su transmisión en la época que nos ocupa.

Observando una pluralidad de definiciones, constatamos que la palabra mito es una de las que posee una práctica más extendida en lo que se refiere a su uso y significado. Su estudio nos permite observar, a través del relato de una historia sagrada, un contexto social dado, realizando una lectura antropológica como manifestación de las creencias de una comunidad específica. En este sentido, examinando las reutilizaciones en la literatura del mito a lo largo de los años, no podemos olvidar uno de sus rasgos fundamentales: su valor ejemplar, propiedad más explotada en la literatura medieval y más concretamente en las dos obras literarias estudiadas. En la narración mítica, los autores medievales ven algo que merece ser recordado como muestra de sus costumbres, como explicación del mundo a través de su mentalidad, como algo que confiere un sentido a ciertas ceremonias propias de una sociedad determinada. El mito tiene una función social elemental y ésta va a ser la aplicación más desarrollada en la literatura medieval.

\footnotetext{
9. Vicensini, J.J., Pensée mythique et narrations médiévales, Paris, Honoré Champion, 1996, p. 43.

10. Eliade, M., Lo sagrado y lo profano, Madrid, Ediciones Guadarrama, 1973, p. 84-85.
} 
Por otra parte y siguiendo con la concepción del mito como modelo de conducta, podemos observar que todos los personajes que aparecen en dichos relatos, adquieren un valor ejemplar, convirtiéndose en representantes de ciertas actitudes y comportamientos que pueden repetirse con las mismas consecuencias, con los que el público puede identificarse viendo en ellos un modelo de conducta o una imagen de cómo no se debe actuar, prestando atención al castigo o la recompensa de sus actos.

Es que el mito ofrece una dimensión atemporal que le concede un carácter repetible y en consecuencia adaptable a nuevos contextos y situaciones. Así su reinterpretación ofrece al público un simbolismo, una manera de percibir la problemática social o moral, relacionada con la sociedad de la época. De esta manera, podemos ver en todas las reescrituras que se han llevado a cabo obras literarias particulares en las que el autor reformula el entramado narrativo del relato mítico presente en el modelo clásico, creando una nueva obra sin variar la temática general.

De esta forma, y siguiendo a Marc Eigeldinger, podemos ver en el mito un relato “qui parle à l'homme de sa destinée, de ses activités, de ses croyances et de ses passions; il est comparable à un soleil autour duquel gravitent les phénomènes de la vie psychique et qui, pour les inscrire dans la durée, fait irradier alentour la lumière du langage $11 "$. En este sentido, el mito intenta explicar el destino del hombre, reinterpretando, según la época, ciertos comportamientos humanos que perviven a lo largo de los años. El apoyo en el carácter universal del mito hace que sus reescrituras tengan un valor de verdad universal.

El estudio del mito ha sido abordado a través de varias perspectivas: una de ellas es la que aborda el mito desde el punto de vista de la antigüedad clásica en oposición con el logos (palabra razonada), entendiendo el primero como el concepto prelógico antecedente de la concepción racional. El sentido platónico del mito se aproxima mucho a una dimensión ideal, es decir, como modelo arquetípico de una realidad que solo es imitación de otra única, inmortal e imperturbable.

Así, según lo que afirma Jean Brun en su libro Platón y la Academia: "El mito es el medio por el cual lo intemporal se torna narración en la boca de los hombres y lo Uno viene a ubicarse en los límites del discurso. Por este recurso, lo invisible deviene 
inteligible para el hombre y, si no perfectamente visible, por lo menos perceptible. Gracias al mito, lo inefable puede relatarse y lo incomunicable se comunica. El mito es una vía analógica que trata de suscitar en nosotros la anamnesis capaz de conducirnos nuevamente al lugar donde se encuentra el origen que hemos olvidado. El mito es una ascensión por medio del $\log _{12}$ ”. Platón recurría al mito como una práctica común, él va a ser el primero que atribuye al mito un valor importante ya que para él es una imagen de la verdad. El mensaje del mito constituye un elemento esencial y auténtico.

Siguiendo la idea de mito como hecho relevante y verdadero vemos que los mitos a los ojos de Schelling "sont nés à l'intérieur de la conscience des peuples. Ils sont le produit d'un processus indépendant de la pensée et de la volonté 13 ”.

Con el paso del tiempo, esta concepción de mito como explicación racional va disipándose poco a poco; así, el siglo XIX vio estas narraciones como simples relatos ficticios, fuente de la ignorancia y la superstición de una humanidad carente de estudios científicos. Sin embargo, a partir del primer cuarto de siglo XX las investigaciones antropológicas dan una nueva visión al mito calificándolo como "verdad" como manifestación de la experiencia humana y cuya existencia tiene un objetivo concreto. Mediante el mito el hombre antiguo conseguía dar una explicación a los distintos acontecimientos de su vida. Era una forma de dominar el mundo, ser dueño de sus actos y de la vida social de acuerdo con sus propios intereses.

Diferentes teorías sobre el mito han llamado nuestra atención respecto a sus orientaciones, y nos han ayudado en el análisis, dado que las hipótesis gravitan sobre el estudio del mito, tal y como lo vamos a abordar en este trabajo de investigación; es decir, entendiendo el mito en su función social.

La primera teoría que vamos a exponer es la de los funcionalistas fu. Los $_{14}$ funcionalistas realizan un estudio del mito en el contexto social y cultural en el que se produce. El mito se estudia en conexión con la vida social, es abordado como parte de un conjunto más vasto: la vida social como sistema complejo de instituciones, de

12. Brun, J., Platón y La Academia, Buenos Aires, Eudeba, 1965, p. 34 ss.

13. Le mythe: son langage et son message: actes du colloque de Liège et Louvain-La-Neuve / édités par H. Limet et J. Ries Louvain-La-Neuve: Centre d'Histoire des Religions, 1983, p. 28.

14. Malinowski, B., Myth in primitive psychology, London, Norton, 1926, p. 95 ss. 
valores, de creencias y de comportamientos. Desde esta perspectiva, el mito está en íntima conexión con la vida real de los hombres, él mismo pertenece plenamente a la realidad.

Los funcionalistas no ven en el mito una explicación que satisfaga un interés científico, sino que más bien a través de su relato pretende satisfacer unas necesidades profundas de todo ser humano: encontrar sentido al mundo, dar respuesta a las necesidades religiosas, aspiraciones morales, convenciones sociales y exigencias prácticas. El mito tiene para ellos una función social dentro de la sociedad en la que se produce. Su función es la de reforzar las pautas de cohesión social y unidad funcional del grupo donde se desarrolla.

Para ellos, el mito supone una especie de codificación del orden tradicional de las instituciones y de las pautas morales que rigen la conducta de los pueblos. Gracias a esta codificación, narraciones que consideramos míticas permiten transmitir de generación en generación ese saber colectivo que constituye la garantía de continuidad del orden cultural propio. El mito es un elemento más de esa abstracción que es la sociedad y cuya finalidad última sería la de garantizar el equilibrio y el buen funcionamiento social.

Así es como entienden el mito los funcionalistas, sin embargo existe otra teoría destacada, la de la Escuela Estructural. La antropología Estructural o Escuela Estructural, cuyo representante es el antropólogo Claude Lévi-Strauss, aborda el análisis del mito en sí y por sí mismo, no lo considera como mera carta de relaciones sociales efectivas o como "superestructuras" que reflejan la estructura social o diferentes modos institucionalizados del comportamiento o las condiciones reales de existencia de un pueblo. El análisis descansa, ahora, en la especificidad del discurso mítico. Aborda su estudio desde el interior del mismo, considerándolo como un universo que es necesario entender como tal.

Para Claude Lévi-Strauss el mito está formado por unidades constitutivas; las unidades constitutivas mayores, que son los elementos mínimos dotados de significación del discurso mítico, son denominadas mitemas ${ }_{15}$.Lo propio del mito es que, al reescribirlo en una época distinta a la que se escribió, se actualiza, dándole una 
característica atemporal.

Otro de los estudios mitológicos destacados es el de Jung ${ }_{16}$, integrante de la Escuela de Zurich y seguidor de la psicología analítica; expone este autor que el mito en su reescritura pasa de ser un símbolo natural a convertirse en uno cultural; dicho de otro modo, supondría el paso de un imaginario individual a un imaginario antropológico de una determinada región.

Para Jung y su escuela de Zurich los mitos son manifestaciones del inconsciente colectivo por las canalizaciones de sus arquetipos, que exclusivamente se refieren al proceso de individuación o integración armónica y total de los componentes psíquicos del ser humano, cuya falta ocasiona los complejos, la neurosis e incluso algunas formas de psicosis y de otros trastornos mentales ${ }_{17}$.Para él, la narración mítica es la forma global que expresa la relación funcional con el entorno, con otros seres humanos y consigo mismo, y se convierte en el inicio de un estilo de vida que le permite a un grupo humano organizarse para sobrevivir y desarrollarse.

Poco a poco, y pasados los años, vemos cómo el mito aparece como un simple soporte y pierde una parte importante de su significado original para adaptarse a la época en la que se reescribe; así el mito nunca será un relato cerrado sino que sus variantes serán múltiples y dependerán en gran medida de la época en la que se reelabore y de la intención del narrador. El mito aparece como un mero soporte para el desarrollo del lenguaje sin tener en cuenta sus características propias. En definitiva, el mito muestra los arquetipos clásicos reformulados y adaptados.

A medida que las reescrituras lo despojan de su carácter mítico, el mito se va convirtiendo cada vez en un relato realista que ofrece una imagen del mundo o la época en la que ha sido reescrito, uniendo tradición y modernidad en una misma narración. El estudio de los mitos sigue interesando a nuestros contemporáneos y así podemos comprobarlo en esta afirmación de Jung citado por Jaffé: «Ninguna ciencia sustituirá jamás al mito, y no se puede crear un mito a partir de ninguna ciencia. Porque no es que «Dios» sea un mito sino que el mito está en la revelación de una vida divina en el

16. Martínez-Falero, L. M., Narciso en España de los orígenes a la desmitificación del mito, Madrid, Ediciones clásicas, 2011, p. 15 .

17. Cencillo, L., Mito, semántica y realidad, Madrid, Biblioteca de autores cristianos, 1970, p. 294. 
hombre. No somos nosotros quienes inventamos el mito, sino que éste nos habla como una Palabra de Dios ${ }_{18}{ }^{»}$. Sin duda alguna, el mito ocupa un lugar muy destacado en la realidad de la actividad humana.

De esta manera, en la trasposición del mito clásico, los dioses no operan las decisiones de los mortales como en la antigüedad clásica, sino que son los propios hombres los que castigan a los culpables reponiendo el orden social perdido. Así la guerra de Troya es una decisión humana que intenta reconstituir el estado inicial con el retorno de Helena a su patria y que culmina con la destrucción de una ciudad.

Como síntesis a esta representación recapitulativa de las teorías sobre el mito, podemos decir como Barthes, que "le mythe est un système de communications, c'est un message, c'est l'histoire humaine qui fait passer le réel à l'état de parole, c'est elle et elle seule qui règle la vie et la mort du langage mythique. Lointaine ou non, la mythologie ne peut avoir qu'un fondement historique, car le mythe est une parole choisie par l'histoire: il ne saurait surgir de la "nature" des choses 19 ".

\section{LAS REESCRITURAS DEL MITO EN EL TEXTO MEDIEVAL}

Tras el esbozo de las principales teorías sobre el mito, vamos a orientarnos hacia las reescrituras mitológicas en la literatura medieval. Las narraciones míticas, y toda presencia de los dioses paganos en un texto medieval, no tienen como misión instruir al lector en el culto de los dioses de la antigüedad sino instruir moralmente al hombre medieval y enseñarle una forma de comportamiento, acercándolo así con sutileza a la cultura clásica de acuerdo con la intención educativa de la literatura en la Edad Media.

De esta forma, el mito, al presentarnos unos personajes tipo y desarrollar una situación concreta, nos ayuda a entender los comportamientos humanos y las consecuencias de sus actos, dando así una serie de directrices que se convierten en pautas de conducta que varían según la época en la que se reescriba el mito.

El motivo por el que un autor medieval reelabora un mito clásico se justifica por el hecho de que el mito presenta una narración cuya historia "ejemplar" ha ocurrido en el "tiempo de los orígenes" o en un pasado remoto, y cuyo significado remite a lo eterno

18. Jaffé, A., The mythe of meaning, Baltimore, Daimon, 1975, p. 373.

19. Barthes, R., Mythologies, Paris, Seuil, 1957, p.193. 
humano, en el sentido del mito según Lévi-Strauss, que "hace referencia simultáneamente al pasado al presente y al futuro $20 "$

En este sentido, los autores medievales se sirven de la cultura clásica adecuando los personajes y la historia a la época en la que se encuentran. Así, convierten a los héroes clásicos en caballeros medievales propiciando el anacronismo que refleja l'impossibilité pour l'homme d'accomplir parfaitement la synthèse du passé et du présent, il représente en même temps une tentative pour échapper aux temps, mais c'est aussi l'objet d'une ingénieuse technique 21.

Los autores de ambas novelas, objeto de este trabajo, no intentan transmitir la religión pagana sino dar a conocer los héroes clásicos y sus hazañas situándolos en la época medieval, de ahí que el anacronismo se multiplique y esté muy presente en las descripciones de los héroes y de las ciudades. Acorde con esta concepción sintética, el espacio y el tiempo están proyectados en una totalidad circular que es la del eterno retorno, puesta en evidencia en Enéas, con la creación de una nueva Troya, y en la novela de Benoît de Sainte-Maure por el regreso de Helena a su ciudad natal. Su ejemplaridad y su valor universal evidencia otra de sus características: un carácter de $\operatorname{arquetipo}_{22}$.

Otra perspectiva complementaria respecto a la reescritura de los mitos clásicos en estas obras, es la de Faral, que expone que «ces écrivains ont abordé l'étude des poètes anciens avec une autre âme, une autre sensibilité et une autre imagination et c'est dans la nouveauté de l'interprétation qu'a consisté leur véritable originalité $23{ }^{»}$. Así el

20. Lévi-Strauss, Cl., Mito y significado, Madrid, Alianza, 1987, p. 189.

21. Petit, A., L'Anachronisme dans les romans antiques du XII siècle, Paris, Honoré Champion, 2002, p. 286.

22. Arquetipo: Según Jung, los arquetipos o imágenes primordiales son "formas o imágenes colectivas que se dan en toda la tierra como elementos constitutivos de los mitos y, al mismo tiempo, como productos autóctonos e individuales de origen inconciente". Son patrones de formación de símbolos que se repiten a lo largo de la historia y las culturas, en la humanidad entera, y a través de ellos buscan expresión las energías psíquicas. Los arquetipos en sí mismos son inaccesibles: los llegamos a conocer, y nunca totalmente, porque se materializan en símbolos concretos. Su carácter primordial no alude solo a que son muy antiguas en la historia del hombre, sino que pueden generarse en cualquier otro periodo histórico, incluso en el actual. Los arquetipos no son ideas innatas heredadas tal cual, sino formas, tendencias, patrones que subyacen a la formación de símbolos. Progoff, I., La psicología de Jung y su significación social, Buenos Aires, Paidós, 1967, p. 93 ss.

23. Faral, E., Recherches sur les sources latines des contes et romans courtois du Moyen Âge, Paris, Slatkine Reprints, 1983 , p. 8. 
proceso de reescritura crea un universo propio en el cual se refleja no sólo lo "eterno" y "circunstancial" del mito antiguo sino que también nos da a conocer una visión personal de la vida y del mundo en el que se escribe.

De hecho, lo que pretende nuestro trabajo es analizar esta dimensión atemporal y reversible de los mitos que, a pesar de ser historias realizadas hace tiempo, se actualizan en las diferentes adaptaciones de los mitos a lo largo de la historia en la literatura y más concretamente en la literatura medieval. En este sentido, el objeto de nuestro estudio, centrado en los dos grandes temas de la novela antigua, el amor y la guerra, es analizar la reescritura de los diferentes mitos cuyo tema principal sea uno de los dos citados. Mientras el tema del amor abre una nueva vía para el desarrollo de la novela, el de la guerra hace referencia a la literatura anterior y más concretamente a la "chanson de geste", creándose así al mismo tiempo un lazo entre esta literatura épica y la literatura cortés que se desarrollará posteriormente.

Como comprobaremos en el análisis de los mitos en ambas novelas, los dos autores prescinden de la vertiente religiosa de esos mitos. A pesar de esto, incluso despojados de su carga mitológica, nos son familiares dado que descubrimos en ellos las pasiones e impulsos que son los nuestros y, en sus personajes arquetipo, destinos que podrían servirnos de paradigma.

La reescritura de un mito está condicionada por hechos históricos y sociales y así la reelaboración de los mitos está sujeta a razones sociales y al deseo de engrandecer al monarca dotándole de parentescos con los héroes clásicos fundadores de grandes estirpes y ciudades gloriosas en el caso de la literatura de la Edad Media francesa.

Mediante el proceso de deformación consciente llevado a cabo por los autores medievales, vamos a ver cómo los elementos que participan en el acto de la creación literaria son susceptibles de consolidarse en el imaginario cultural. Los mitos tratados en la época medieval son los mismos que han pervivido en la sociedad moderna estableciendo varios cambios. La literatura, por tanto, alimenta de esta manera el mito que es utilizado y reutilizado. Tradicionalmente oral, encuentra en la literatura una forma nueva de transmisión y consolidación en el imaginario humano perviviendo así durante años: "La fonction du mythe est symbolique et analogique, elle consiste à découvrir et à dire les similitudes entre le contenu du récit et l'existence humaine. Le 
mythe dispose d'une puissance d'incarnation, il comporte une valeur religieuse et initiatique, de telle sorte qu'il peut être considéré comme un logos sacré 24 ".

Por otra parte, el mito propone una imagen ejemplar de la condición humana desde una perspectiva tanto ontológica como cosmológica. Así, "le mythe littéraire ne se maintient en vie et ne recrée sa signification que par la transmutation, par la force de renaître et de se dépasser grâce aux pouvoirs de l'imagination, qui est la faculté de la métamorphose. Le langage établit la cohérence du mythe littéraire et il est la condition de sa résurrection permanente $25 \%$.

Al realizar una lectura superficial de los mitos presentes en las dos novelas, observamos que, salvo el de la fundación de la nueva Troya con la unión de Eneas y Lavinia, son mitos trágicos. Como dice Nietzsche, "dans la mesure où il relève de l'art le mythe tragique participe des fins propres de l'art et travaille à cette transfiguration métaphysique du réel qui est la fin de tout $\operatorname{art}_{26}$ ”.En esta medida, el mito contribuye en gran medida al avance de la literatura como arte humano.

Por otro lado, la importancia de la reescritura de los mitos clásicos no reside en la transmisión de la religión sino en el triunfo de la obra literaria sobre la creencia ancestral. De este modo "nous connaissons les mythes à l'état de "documents" littéraires et artistiques, et non pas en tant que sources ou expressions d'une expérience religieuse solidaire d'un rite $_{27}$ ".

También así, la introducción de los mitos tiene otras funciones dentro del texto medieval: la primera, actuar como una digresión, una pausa en la acción y, la segunda, ofrecer al mismo tiempo un dispositivo que entrelace las acciones sucesivas. Se desarrollan ambas funciones en cada uno de los episodios mitológicos analizados en las novelas de nuestro estudio.

De este modo, observando precisamente la presencia del mito de Troya, es como hemos distinguido la anticipación de dos temas centrales que aparecen en las dos

\footnotetext{
24. Eigeldinger, M., Lumières du mythe, Paris, PUF, 1983, p. 8.

25. Ibid., p. 15 .

26. Nietzsche, op. cit. p. 120.

27. Eliade, M., Aspects du mythe, Paris, Gallimard, 1963, p. 193.
} 
novelas de la triada clásica: el amor y la guerra. Además, el mito troyano no sirve sólo para dar a conocer los arquetipos de hombres clásicos, transformados en caballeros medievales sino para justificar las raíces del pueblo francés con la tradición heróica clásica. Tal y como lo expone Colette Beaume en su libro Naissance de la nation France, «l'histoire de France a un sens et l'acquis de tous les siècles converge pour former la nation, fruit inéluctable du temps. Si l'on s'en tient aux méthodes de l'histoire politique classique, on se borne donc à raconter les événements ou à privilégier tel ou tel facteur de cohésion. Mais on écrit toujours une histoire des faits, on tente de cerner ce qu'est la France médiévale. La France n'est plus fille de l'événement, mais reste fille des faits $22^{»}$. El mito sirve para otorgar un pasado prestigioso a la nación Francia que en el siglo XII empieza a germinar.

Tenemos que tener en cuenta que es durante el siglo XII cuando aparecen de manera explícita los primeros intentos por definir la nación francesa y a través de la translatio studii, se encuentran en los héroes clásicos personajes que contribuyen a transmitir el origen glorioso de una nación en progreso. Así, difundiendo el saber clásico, se crean una serie de símbolos y leyendas que servirán para aumentar la gloria de la nación naciente.

De esta forma, «l'histoire de la France telle qu'on la conçoit au Moyen Âge écarte presque l'histoire du présent insaisissable et multiforme. C'est surtout une histoire du passé, car l'avenir est l'affaire des prophètes et non des historiens. La nation, comme tout homme, a besoin de racines. Seul ce qui a été a valeur de référence. Le passé est clair, connu, articulé logiquement, il a le poids de l'être, il rassure et il enseigne. C'est un ensemble d'exemples moraux propres à guider l'action des générations présentes 29 ». Así, con la translatio los autores dan un pasado a una nación que carecía de él, un pasado glorioso que hace que sus dirigentes desciendan de los guerreros troyanos, nobles caballeros fundadores de grandes ciudades.

Los personajes que aparecen en estas novelas son ejemplos morales de caballeros; al exponerse la leyenda troyana, se intenta transmitir la gloria de un pueblo luchador y fundador, y no, como hemos dicho su religión ligada a ritos paganos que

28. Beaume, C., Naissance de la nation France, Paris, Gallimard Collection Folio/Histoire, 1985, p. 12.

29. Ibid., p. 21. 
chocan con la religión cristiana: «Les origines de la France commencent pourtant paradoxalement par une légende païenne. Les origines troyennes des Francs ont été créées au VII siècle sur le modèle antique de la fondation de Rome par les exilés troyens conduits par Enée. Comme les Romains qui gouvernèrent le monde, les Francs ou Français sont issus de la race la plus ancienne et la plus noble $30^{»}$.

Así, se justifica de forma racional la preexistencia de la leyenda troyana en la época medieval y su explicación coherente para unirla a los orígenes y el pasado de la nación Francia, que se quiere comparar con la imagen de la fundación de Roma. En esto mismo, podemos ver una de las funciones del mito, la función social: mediante el mito los orígenes franceses adquieren una gloria legada por el pasado troyano de sus dirigentes.

Directamente relacionada con la presencia del mito, se halla claramente la trifuncionalidad. Dentro de las dos novelas analizadas, sirve como marco de la distribución ideal de los hombres y como instrumento de clasificación que se emplea para celebrar a tal jefe, guerrero o tal soberano ${ }_{31}$. Recordemos que desde el origen la sociedad indoeuropea estaba dividida en tres: los oradores, los guerreros y los labradores. Los estudios de G. Dumézil ${ }_{32}$, descubrieron una tripartición aparente en la India y en Irlanda a través del análisis de múltiples hechos culturales (mitos, ritos, tradiciones...), distinguiendo tres grandes clases jerarquizadas que colaboran entre sí en la vida de conjunto del grupo; estas tres funciones corresponden a los que se dedican a orar, los que se dedican a pelear y los que se dedican a suministrar los alimentos. Adaptadas a la sociedad medieval, estas tres funciones aparecen formuladas como impuestas por Dios desde el comienzo: oratores, bellatores y laboratores, para garantizar el equilibrio de la sociedad y cumplir con la voluntad de Dios.

La creación de estas obras está justificada, como dice A. Petit, en el contexto de la época: "ce souci de faire acquérir au public romanesque des connaissances précises s'inscrit nettement dans la perspective de l'humanisme du XII siècle 33 ”. Así las obras

30. Ibid., p. 22.

31. Duby, G., Los tres órdenes o lo imaginario del feudalismo, Barcelona, Petrel, 1980, p. 13.

32. Dumézil, G., Mythe et épopée, París, Gallimard, 1986", 251-271; cf. una prolongación medieval de estos temas en J. H. Grisward, Archéologie de l'épopée médiévale, Paris, Payot, 1981, p. 20.

33. Petit, A., Naissance du roman.Les techniques littéraires dans les romans du XII siècle. T.II, Paris, Champion, $1985, \mathrm{p} .824$. 
analizadas se inscriben en esta perspectiva humanista del siglo XII, que utiliza obras clásicas como fuentes de transmisión de la cultura, y en el contexto literario marcado por la gesta. "Le lieu commun entre romans et chansons de geste se vérifie chaque fois que l'on aborde la narration des combats, même dans l'Enéas, l'oeuvre pourtant la moins marquée, aux dires d'A. Petit”. Esta cita de F. Mora 34 es la que justifica el segundo capítulo de nuestro estudio en el que estudiaremos la guerra y los cambios que ha sufrido el tema desde la chanson de geste hasta las novelas analizadas. La influencia de la literatura anterior se verifica en la descripción de los numerosos combates presentes en ambas novelas, así su estudio nos permitirá ver la evolución en el tratamiento de los combates y luchas, tan presentes en la mentalidad medieval.

A pesar de los modelos literarios con los que se cuenta para la realización de la amplificación de los episodios presentes en su novela, entre ellos, la canción de gesta que se utiliza para la narración de combates y enfrentamientos, opta por variar ciertos comportamientos, dándoles una importancia esencial dentro de la novela e introduciendo una nueva forma de tratamiento del mito y del personaje femenino, abriendo así una nueva vía a la literatura, que se desarrollará plenamente en el "fín $\operatorname{amor}_{35} "$

Ha sido teniendo en cuenta todos estos aspectos teóricos como he podido adentrarme en los dos temas seleccionados como objeto de reflexión y análisis. Así, el primer capítulo versará sobre los elementos mitológicos representados en el Roman de Troie y en el Roman d'Enéas, partiendo del análisis de las tramas amorosas presentes en ambas novelas. Estudiando los episodios y los sub-episodios amorosos más importantes, consideraremos lo que los autores de ambas obras han conservado de su hipotexto, es decir qué mitos están desarrollados y cuáles ausentes o modificados y cómo se refieren a los episodios mitológicos dentro del hipertexto 36 .

34. Mora, F., «De l'Énéide à l'Énéas: le traducteur médiéval à la recherche d'une nouvelle stylistique», in Bien Dire et Bien Aprandre Revue de Médiévistique nº13, Lille, CEMD, 1997, p. 31.

35. Badel, P.Y., op. cit., p. 79 ss.

36. Utilizamos la terminología genetiana: «J'ai délibérément différé la notion du quatrième type de transtextualité. J'entends par là toute relation unissant un texte A (que j'appellerai hypertexte) à un texte B (que j'appellerai bien sûr hypotexte "). "J'appelle donc hypertexte tout texte dérivé d'un texte antérieur par transformation simple (nous dirons désormais transformation tout court) ou par transformation indirecte: nous dirons imitation.” Genette, G., Palimpsestes, Paris, Seuil, 1982, p. 11-14. 
El segundo capítulo centrado, como ya he dicho, en uno de los temas más comunes en la literatura medieval, la guerra, revela igualmente elementos mitológicos mediante el anacronismo, no sólo en los personajes sino también en el escenario de las batallas, tanto en Enéas como en Troie. En este apartado la reflexión se centra en los cambios realizados por los autores medievales, con relación a sus fuentes, como en el caso de la trayectoria de Eneas, no sólo en la obra medieval sino también en su propio modelo clásico: la Eneida. En cuanto a Troie analizaremos dos hipotextos clásicos, obras de dos autores testigos presenciales: Dictis Cretense y Dares Frigio, observando ciertas variaciones que efectúa el autor medieval frente a sus modelos para comprender el proceso de reinterpretación. El estudio de este tema evidencia valores morales y sociales de la época, convirtiendo en el caso del Roman d'Enéas, a Eneas como modelo de caballero. El análisis de su viaje iniciático nos descubre los valores inherentes al ideal caballeresco. El punto de vista se amplía en este apartado con la comparación de ciertos episodios bélicos con los modelos clásicos y la observación de variaciones provocadas por la mentalidad medieval de los autores.

El marco del tercer capítulo es el manuscrito BN fr60, datado del s. XV, que evidencia la importancia y la trasmisión de dichas novelas a lo largo del tiempo. Para realizar este último estudio, he efectuado un examen comparativo de los dos temas tratados a lo largo de este trabajo de investigación, a partir de la observación de las miniaturas relacionadas con estos temas, presentes en el manuscrito BN fr60. Para el estudio de la imagen me he servido del libro de F. Garnier, Le langage de l'image 37 , en el que se realizan también numerosas descripciones de miniaturas de otros manuscritos. El análisis de las miniaturas me ha permitido reencontrar los fragmentos más destacados de la obra y sobre todo los que resultaban más significativos para el miniaturista, dejando patente la importancia concedida al tema de la Guerra.

El análisis pretende destacar las diferencias operadas por el miniaturista frente a la obra escrita, tomando como punto de partida descriptivo las obras de la investigadora Laurence Harf-Lancner. Este apartado, que cierra mi trabajo, se centra no sólo en la permanencia de la mitología en las miniaturas sino también el grado de fidelidad de la representación de ciertos episodios de la novela. De este modo, he querido destacar que, 
al igual que las novelas medievales estudiadas (Troie y Enéas) sirven como primer eslabón de lo que hoy conocemos como novela, las miniaturas presentes en los manuscritos son el germen de la pintura ilustrativa tal y como la conocemos hoy en día. Este último capítulo se cierra con el análisis de dos miniaturas en las que se observa de forma explícita la presencia de lo maravilloso que ha estado presente de forma directa o indirecta a lo largo de todos los capítulos de este trabajo. Lo maravilloso desempeña un papel de primer orden en la reescritura del texto antiguo, modificando la lectura al crear una atmósfera diferente, propicia para transmitir los valores estéticos e ideológicos que el autor medieval ha plasmado en el texto de su translatio, así lo maravilloso se hace reflejo y espejo del imaginario medieval.

El estudio del mito en las novelas antiguas de la literatura francesa ya ha sido tratado ampliamente por autores destacados como Aimé Petit y Francine Mora, los cuales han aportado numerosas visiones sobre las innovaciones realizadas por los autores medievales respecto a los hipotextos clásicos. La originalidad de mi trabajo de investigación reside en el acercamiento "temático" al que me he ceñido: el amor y la guerra, a través de una selección de episodios que permiten no sólo apreciar las variaciones significativas con respecto al modelo clásico sino también, en el tratamiento textual de los dos temas, un nexo de unión entre ambas novelas analizadas.

En este sentido, mi estudio pretende mostrar que, a pesar de ser dos novelas del siglo XII aún conservan su interés en nuestros días y que cada adaptación, ya sea la de Enéas a partir de la Eneida, o el relato medieval de la guerra de Troya por Benoît de Sainte-Maure, otorga una nueva imagen de la historia, sin que se pierda lo esencial y fundamental del significado y ello precisamente gracias a las aportaciones efectuadas por cada uno de los diferentes autores, particularmente en lo que se refiere al tratamiento del amor y la guerra, binomio temático que ha sido el hilo conductor de este trabajo. 


\section{EL AMOR EN EL ROMAN DE TROIE Y EN}

EL ROMAN D'ENÉAS 


\section{INTRODUCCIÓN}

Para desarollar este primer capítulo de nuestro trabajo, hemos seleccionado los mitos y tramas amorosas más destacados. Hemos empezado por Troie, debido a la variedad cuantitativa de tramas amorosas presentes en la novela, a pesar de que la aparición de esta novela es posterior a la de Enéas (E. Faral sitúa a Enéas hacia el año 1150 y Troie entre los años 1165 y 1170), dedicando el estudio a las tramas amorosas de Medea y Jasón, Paris y Helena, Troilo, Briseida y Diómedes y finalmente la de Aquiles y Policena. Y en el siguiente apartado, el trabajo se centra en las dos tramas amorosas dominantes en Enéas: la primera, Eneas y Dido y la segunda, Eneas y Lavinia.

Al analizar estas tramas no sólo nos fijaremos en las diferentes fases de la declaración amorosa sino que descubrimos el código con el que los escritores de esta época tratan al Amor. Por otra parte, todo ello nos permite ver la evolución del género femenino y su tratamiento literario, así como el desvanecimiento del ideal de caballero tan extensamente tratado por el cantar de gesta, y su conversión en vasallo del amor, por la cual poco a poco va dejando la conquista de territorios para dedicarse a la conquista amorosa. Los primeros ideales de hombres medievales, tan representados en las primeras obras épicas dejan paso al resurgir de un nuevo caballero centrado en un nuevo campo, el campo del Amor, entendido tal y como lo entendían los clásicos como Ovidio, el "amour-maladie", del que nadie puede escapar, contra el que nadie puede luchar y del que sólo se escapa mediante la muerte.

\subsection{EL AMOR EN EL ROMAN DE TROIE: ANÁLISIS DE ELEMENTOS MITOLÓGICOS PRESENTES EN LAS TRAMAS AMOROSAS}

Como punto de partida, el análisis de la primera trama amorosa nos da a conocer a un nuevo tipo de mujer: la hechicera, que posee cualidades extraordinarias; la trama correspondiente va a ser una de las más fieles a la obra clásica, omitiéndose solamente la muerte de la protagonista. También vemos en Medea la personificación de lo maravilloso. Mujer traicionada, Medea nos muestra la experiencia de una mujer 
desdichada en el amor y se relega a Jasón a un segundo plano, prototipo del ideal de caballero. Al estudiar esta trama, hemos querido clasificar los diferentes estados por los que pasan los protagonistas, enumerando las etapas y desglosando el desarrollo de la intriga amorosa, dando así a conocer el código habitual adoptado en la Edad Media para narrar las historias de amor. En efecto, la mirada, el gesto y por último la palabra, constituyen un corpus en las situaciones que hemos analizado, dejando patente un código fijo dentro de la descripción del Amor. Esta trama amorosa ocupa un total de unos 819 versos (v.1211-2030) y nos presenta al primer caballero de la obra.

La segunda trama seleccionada es la de Paris y Helena, de gran importancia por su peso en la narración y por ser el desencadenante de la destrucción de Troya, nombre emblemático que adopta la novela. En el análisis de esta trama hemos querido centrarnos no sólo en el tratamiento de la intriga amorosa que expone Benoît de SainteMaure, sino también en los cambios del mito clásico, así como en el sentimiento del arrepentimiento y la negatividad del amor-pasión. En la figura de Helena podemos apreciar tanto la negatividad del amor, tema causante de muerte y destrucción, como la imagen negativa de la mujer medieval. Esta trama comienza en el verso 4167 y se extiende a lo largo de la novela hasta el final, sin duda ésta es la trama amorosa trascendental dentro de la obra.

El tercer pasaje analizado es el trío que protagoniza Briseida y sus dos amantes. Por primera vez aparece una trama amorosa con dos protagonistas masculinos. En este episodio, sorprende la inversión de papeles en la conquista del ser amado; los protagonistas masculinos tomarán la palabra y los signos externos del amor se materializarán en ellos, siendo las víctimas insconscientes del Amor. Esta trama llama la atención por su carácter novedoso y propiciará una pausa narrativa con respecto al hilo conductor: la conquista de Troya. Durante los más de 400 versos (v.13261-13866), (v. 14959-15186) que ocupa este episodio, el autor nos revela una nueva actitud masculina.

Finalmente la última trama que ocupa nuestro estudio en la novela de Troie, es la de Aquiles y Policena, totalmente creada por el autor. En esta trama vemos cómo ciertos episodios clásicos desaparecen y se sustituyen por otros menos hirientes para la mentalidad medieval. Gran caballero, Aquiles también es el gran guerrero, el conquistador conquistado y derrotado. Esta trama nos expone a lo largo de unos 900 versos (17489-18472), la actitud del caballero frente al amor. 
Antes de comenzar el estudio detallado, cabe destacar que el autor de esta novela, Benoît de Sainte-Maure, no utiliza a Homero para realizar su translatio sino que la realiza a través de dos obras de dos autores testigos presenciales de la guerra de Troya, participantes de los hechos de uno y otro bando. Por un lado, Dares Frigio, en el lado troyano, que compone un breve texto en prosa alrededor del s. VI, De excidio Trojae, y por otro lado, Dictis Cretense, que escribe desde el bando de los griegos su obra Ephemeris belli Trojani. Así el autor, relega a un segundo plano la obra de Homero la Ilíada, dando más importancia a los autores que para él transmiten de una forma más efectiva los hechos que él va a adaptar en su novela. Los hipotextos de esta novela serán pues dos obras de dos poetas diferentes que reelaboran a su vez la tradición homérica y que Benoît presenta explícitamente, como referencia y prueba de historicidad:

Un jor esteit en un almaire

Por traire livres de gramaire;

Tant i a quis e reversé

Qu'entre les autres a trové

L'estoire que Daire ot escrite,

En grecque langue faite et dite.

Icist Daire que vos öez

Fu de Troie norriz e nez;

Dedenz esteit, unc n'en issi

De ci que l'osz s'en departi;

Mainte pröece i fist de sei

$\mathrm{E}$ a asaut e a tornei.

En lui aveit clerc merveillous

E des set arz escientos.

(V. 87-100)

De grec le torna en latin

Par son sens e par son engin.

Mout en devons mieuz celui creire 
E plus tenir s'estoire a veire

Que celui que puis ne fu nez

De cent anz o de plus assez,

Que rien n'en sot, ice savon,

Se par oïr le dire non.

(V.121-128)

Niul autre rien n'i voudrai metre

S'ensi non cum jel truis escrit.

Ne di mie qu'aucun buen dit

N'i mete, se faire le sai,

Mais la matire en ensirrai.

(V.140-144)

Sin embargo, y como podemos constatar en Troie, aunque el texto de Homero no aparece citado en la obra medieval, nos damos cuenta, como expone F. Mora, que el texto latino está presente indirectamente en la memoria de los auditores:"Il nous semble en effet que même lorsqu'aucune référence explicite n'est faite au modèle latin, le texte démarqué est fort bien connu, a été soigneusement scruté et reste toujours présent, dans le travail de transposition, à la mémoire de l'adaptateur sinon du lecteur 38 ".

Esta elección va a condicionar en gran medida la presencia o ausencia de los elementos mitológicos en su obra ya que, dando prioridad a estos dos autores frente a la obra de Homero, el poeta relega a un segundo plano la obra clásica que, incluso, presenta como ficticia y superficial. Esta idea está presente desde el inicio de la novela, donde Benoît de Sainte-Maure expone el porqué de su elección en cuanto a sus dos obras de base:

38. Mora, F., «De l'Énéide à l'Énéas: le traducteur médiéval à la recherche d'une nouvelle stylistique», in Bien Dire et Bien Aprandre Revue de Médiévistique nº13, Lille, CEMD, 1997, p. 22. 
Omers, qui fu clerz merveilleus,

Des plus sachanz, ce trovons nos,

Escrist de la destruction,

Del grant siege e de l'achaison

Par quei Troie fu desertee,

Qui onc puis ne fu rabitee.

Mais ne dist pas ses livres veir,

Car bien savons, sens niul espeir,

Qu'il ne fu puis de cent anz nez

Que li granz osz fu asenblez.

(V.45-54)

Tras esta precisión sobre los hipotextos de Troie, pasamos al análisis de los mitos de la tradición clásica que aparecen reelaborados en las dos novelas, objeto de nuestro estudio. En un primer momento analizaremos los mitos cuyo tema central es el amor $\mathrm{y}$, tal y como hemos dicho antes, que emergen dentro de las cuatro tramas amorosas seleccionadas, exponiendo las diferentes actitudes desarrolladas por personajes totalmente adaptados a la mentalidad medieval.

\subsubsection{JASÓN Y MEDEA O LA TRAICIÓN DE UNA PROMESA. MITO MEDIEVAL Y MITO CLÁSICO}

Antes de considerar la recepción del mito en la obra medieval, recordemos rápidamente el mito clásico. Según la tradición clásica, por orden del rey Pelías, Jasón reúne una tripulación de héroes para ir a buscar el vellocino de oro a la Cólquida, país muy alejado de Grecia. En un viaje lleno de aventuras y peligros, los Argonautas llegan a su destino. Allí, Jasón debe superar unas pruebas de valor que le impone el rey de la Cólquida, Eetes. Pero a Jasón lo ayuda a culminar estas pruebas y a robar el vellocino de oro la hija de Eetes, Medea, que se ha enamorado de él. Jasón huye de la Cólquida acompañado de Medea y, una vez en Grecia, se casa con ella y tienen dos hijos. El matrimonio y sus hijos se establecen en la ciudad de Corinto. Con el tiempo, Jasón se 
enamora de la joven hija del rey de Corinto, Antígona, se promete con ella y repudia a Medea como esposa y la abandona.

Este es, pues, el mito original de Jasón y Medea según la tradición clásica. Al compararlo con el relato que reescribe Benoît de Sainte-Maure, observamos por de pronto que omite parte del mito clásico: no hace sino una selección, que es la que precisamente quiere transmitir en su obra. En efecto, la historia de Jasón y Medea después de la conquista del vellocino queda totalmente eliminada de la novela medieval, centrándose el interés del autor medieval en la trama amorosa, en su inicio y en las pruebas para conquistar el vellocino de oro. El amor y la batalla van a ser los dos temas principales en este mito, así como ocurre en la novela medieval de este periodo.

Por otro lado, hay que destacar que la historia de Medea ha tenido un amplio tratamiento desde la antigüedad clásica: desde el primer texto que sirve de inspiración para la historia de los argonautas que es sin duda La Odisea, pasando por La Teogonía de Hesíodo a mediados del siglo VIII a. c., la cuarta Oda Pítica de Píndaro y la tragedia homónima de Eurípides, ambas del siglo V a.c., con lo cual este mito está muy presente en la mentalidad clásica.

En la novela medieval, la historia de Jasón y Medea comienza con el deseo del tío de éste de alejarlo de su reino por miedo a que le usurpe el trono. Este matiz negativo recuerda la Chanson de Roland, en la que la designación de Roldán por parte de Ganelon para ser el emisario se rige por la envidia. El carácter negativo estará presente en toda la trama amorosa, hasta su final, ya que desde el inicio, este carácter nocivo anuncia el fatal desenlace de la trama amorosa:

Peleüs fu de mal porpens:

Ne vit engin, ne lué, ne tens

Cum faitement poïst ovrer

De son nevo a mort livrer.

Ses niés esteit, mout le dotot,

Mais ne voleit pas ne n'osot

Monstrer ne faire aucun senblant

Qu'il le haïst ne tant ne quant. 


\section{Porpensa sei qu'il requerreit \\ E en toz sens porchacereit \\ Coment Jason la en alast,}

Si que ja mais n'en retornas

(V. 781-792)

El autor insiste en el carácter dañino del viaje que le propone su tío a Jasón, llenando su narración con palabras negativas: "mal porpens", "mort livrer", "le haïst", “ja mais n'en retornast”, descubriendo sus intenciones tóxicas contra su sobrino por el miedo de que le usurpe el trono. Aparece ya desde el principio el motivo de la lucha, una lucha que el tío de Jasón intenta eludir mandando a su sobrino a una empresa de la que sabe que “ja mais n'en retornas”. La promesa del tío de Jasón consolida la faceta de caballero que Jasón tiene medio desarrollada, al no poseer una tierra para gobernar. En Jasón vemos dos de las características principales de los caballeros de las canciones de gesta: la iniciativa a la acción y la lealtad a su señor y a su linaje.

Aflora de esta manera, desde las primeras apariciones de Jasón, su faceta de caballero. Jasón nos es descrito como un verdadero caballero, destacándose dos etapas: la etapa de caballero, presente durante toda la trama, y la de hombre, presente solamente en el desarrollo de la trama amorosa con Medea. Su actitud positiva y negativa también está unida a sus diferentes etapas: así Jasón estará marcado positivamente cuando actúa como caballero y negativamente cuando actúa como hombre. Al estar de esta forma más marcada su faceta de caballero, se ve tentado por la oferta de su tío y no le causa ningún remordimiento el abandono de Medea, justificado por el ideal caballeresco:

“Dame, fait il, ne m’esmaiez.

Ne sui mie por ce venuz

Que m'en torge cum esperduz.

Mieuz voil morir que je n'essai

S'en niul sens aveir la porrai.

Se o mei ne l'en puis porter,

Ja mais ne m'en quier retorner, 
Quar a toz jors honiz seroie,

Si que ja mais henor n'avroie.

(V.1388-1397)

Junto con esta justificación de la conquista afectando la trama amorosa de Jasón y Medea, aparece uno de los motivos literarios más relevantes y en numerosas ocasiones relatado, el de la mujer enamorada y traicionada.

Según la antigüedad clásica, Medea $_{39}$ era la hija de Eetes, rey de la Cólquida y de la ninfa Idía. Pero en el texto medieval, destaca el arquetipo de bruja o hechicera, que hace de Medea una de las mujeres que representan, como la Sibila de Cumas, el saber sobrenatural, tal y como lo explicitan los siguientes versos:

Trop iert cele de grant saveir.

Mout sot d'engin, de maïstrie,

De conjure, de sorcerie;

Es arz ot tant s'entente mise

Que trop par iert saive e aprise;

Astronomie e nigromance

Sot tote par cuer dé s'enfance.

D'arz saveit tant e de conjure

De cler jor feïst nuit oscure.

S'ele vousist, ce fust viaire

A ceus por cui le vousist faire.

Les eves faiseit corre ariere.

Scientose iert de grant maniere.

(V. 1216-1228)

39. Grimal, P., Diccionario de mitología griega y romana, Barcelona, Paidós, 1994, p. 336. 
Aunque posee dones relacionados con lo divino, Medea representa el saber irracional, es en sí un personaje maravilloso que va a sobrevivir en la mentalidad medieval. La figura de la bruja a pesar de estar condenada por la Iglesia y por la cultura oficial de la época, surge con gran fuerza en la literatura de la segunda mitad del siglo XII: "La figure de la femme merveilleuse joue un rôle fondamental. Magicienne et fée sont les survivantes d'ancestrales et traditionnelles croyances qui, condamnées par l'Eglise et proscrites par la culture officielle du Haut Moyen Age, surgissent avec force et avec succès dans la littérature à partir de la deuxième moitié du XII siècle $40^{» » .}$

La magia es para Benoît de Sainte-Maure la forma superior del saber que une el hombre a Dios. Como maga ostentadora de este poder sobrenatural, Medea es la depositaria de un saber inaccesible a la mayoría de los hombres. Es uno de los personajes femeninos de la novela, junto con Casandra, que posee este don que la aleja de los seres humanos y la convierte en una de las elegidas para comunicarse con el saber supremo. Ambas mujeres, a pesar de sus conocimientos, van a tener destinos desgraciados, una por el abandono de Jasón, la otra por saber el trágico final de su patria y por no ser creída.

Acabamos de ver cómo el tratamiento del personaje de Medea en el texto de Benoît resalta el valor de su participación sobrenatural que modifica el relato original, revistiéndolo de rasgos propios del imaginario medieval. No se desvía por ello de la trama amorosa que se desarrolla siguiendo al mito clásico en el que no existe el carácter maravilloso de la figura de Medea, sino que emerge de la reescritura.

Siguiendo las etapas de la trama amorosa que nos presenta Benoît de SainteMaure, observamos que la primera información que vamos a tener de Medea va a ser la de heredera de la Cólquide, c'ert une fille qu'il aveit (v.1213). El autor se distancia por primera vez de la tradición clásica omitiendo el origen divino (es hija de una ninfa) de la hija del rey Eetes, y da prioridad a la función de reina heredera que en un futuro desempeñará su hija, más acorde con la tradición medieval. Así vemos que Medea ostentará el papel más elevado de una mujer para el s. XII, el de reina, encargada de garantizar la transmisión de la sangre a un heredero varón cuya existencia era 
considerada esencial para la sucesión pacífica en el poder ${ }_{41}$.

Después de una descripción de sus dones intelectuales extraordinarios y de su posición social, omitiendo su aspecto físico, del que sólo nos dice qui demout grant beauté esteit (V.1214), el autor nos presenta una Medea dispuesta a acoger gratamente a Jasón. Es el lado mágico y sobrenatural el que va a llamar la atención de Benoît de Sainte-Maure y que prevalece en la mayoría de las intervenciones de Medea:

\author{
Sot que li reis la demandot, \\ Si s'atorna plus bel que pot. \\ (...) \\ Quant ele certainement sot \\ Que c'ert Jason, mout par li plot; \\ Mout en aveit oï parler \\ E mout l'aveit oï löer.
}

(V.1229 -1260)

Por el valor importante de la fama que precede al personaje en la Edad Media «Mout en aveit oï parler / E mout l'aveit oï löer» y con el adverbio "certainement", podemos observar en Medea una actitud de certeza ante la inminente presentación de Jasón, junto con su predisposición, como heredera de la Cólquida, a acoger el extranjero; guiada por el saber sobrenatural que posee, podrá colaborar en la misión de Jasón antes de que el propio caballero la exponga:

\footnotetext{
"Jason, fait ele, bien savon

Que vos venez por la toison.

Onques por el ça ne venistes"
}

(V. 1333-1335)

41. Wade Labarge, M., La mujer en la Edad Media, Madrid, Nerea, 2003, p. 71. 
Una de las analogías con el mito clásico es el flechazo entre Jasón y Medea. En ambos relatos se produce de forma natural, y la hija de Eetes muestra claramente desde un primer momento sus sentimientos hacia Jasón: mout l'aama enz en son cuer. Medea es el personaje femenino acorde con la nueva tradición que va a surgir en el siglo XII, del que son fiel reflejo nuestras novelas, el que ostenta el papel activo en la acción amorosa.

El mito de Jasón y Medea nos sirve de ejemplo para describir los pasos o etapas representativas que se repetirán a lo largo de las demás tramas amorosas y que formarán un esquema para su elaboración en la Edad Media. Analizándolas en función de este esquema, vamos a ver cómo todas ellas siguen un patrón en el que sólo varían pequeños detalles que el autor permuta para no caer en la redundancia. Así se opera el primer cambio, por una parte con respecto al mito clásico: la amplificación por parte del autor medieval de las fases del enamoramiento ausentes en la fuente clásica; y por otra, con respecto a la poesía épica anterior en la que la mujer quedaba relegada a un segundo plano, tratada como una recompensa de guerra o como madre o esposa siempre ligada a un hombre.

Como se puede observar en la literatura medieval y más concretamente en las dos novelas antiguas de nuestro estudio, la lectura nos deja ver la existencia de una red lingüística y semiótica por la cual el autor nos trasmite el discurso de los personajes y más concretamente el del personaje enamorado, objeto de análisis de este primer punto. Así comprobamos que "geste et parole donc, se constituent en pivot privilégié de la communication dans la société médiévale 42 ".

Cabe recordar la importancia en la Edad Media no sólo del discurso oral, sino también del discurso gestual de los personajes. En una sociedad en su mayoría iletrada, los gestos estaban provistos de un sentido que sobrepasaba muy a menudo el valor de la respuesta dada o de las palabras intercambiadas 43 .

42. Aramburu, F., Desprès, C., Benito, J, «La déclaration amoureuse dans la littérature médiévale », in Bien Dire et Bien Aprandre Revue de Médiévistique, nº15, Lille, CEMD, 1993, p.72.

43. Akkari, H., «La déclaration amoureuse de l'héroïne dans la chanson de geste ou pour une autre poétique amoureuse», in Bien Dire et Bien Aprandre Revue de Médiévistique, n 15, Lille, CEMD, 1995, p.7 ss. 


\subsubsection{ANÁLISIS DE LA TRAMA AMOROSA JASÓN-MEDEA}

Expuestos estos rasgos diferenciados, vamos a analizar el episodio amoroso de Jasón y Medea, siguiendo las fases en las que se dividen tradicionalmente las tramas amorosas en las novelas antiguas, proponiendo el modelo de análisis expuesto a lo largo del artículo de «La déclaration amoureuse dans la littérature médiévale»44, viendo así cómo se puede adaptar a la trama amorosa de Jasón y Medea:

\section{PRIMERA FASE: EL PENSAMIENTO}

Se corresponde con el período en el que los personajes principales ya tienen una actitud positiva ante su amado/a. A pesar de no haberse visto ya sienten admiración por toda la información que ya poseen acerca de ellos. Esta fase se intensifica al haber un primer encuentro entre los protagonistas. Esta etapa relega la palabra a un segundo plano y el protagonista reflexiona sobre lo que le está pasando. Es una etapa intimista en el que el protagonista analiza sus estados de ánimo. Se produce en este periodo una atracción evidente del ser amado.

\section{SEGUNDA FASE: LA MIRADA}

Etapa en la que el enamorado se fija en las cualidades físicas y morales de su amado/a. Normalmente aparecen las descripciones idealizadas de los personajes principales, buscando esa belleza ideal. La descripción de la belleza femenina no busca la objetividad, es decir el realismo, sino que los retratos que se nos presentan buscan lo sublime, deformando conscientemente la realidad.

44. Op., cit.., p. 72-94. 
La descripción es una estilización consciente y querida de tendencia afectiva. Así el autor, describiendo a un personaje con cualidades tan sublimes, quiere provocar en el lector un sentimiento de adhesión o proponerle un modelo a seguir en su conducta 45 .

\section{TERCERA FASE: EL GESTO}

Etapa en la que se producen intercambios gestuales propios de los enamorados por parte de ambos personajes.

\section{CUARTA FASE: LA PALABRA}

Este es el momento en el que se realizan los primeros intercambios de palabras que afianzan la primera fase del enamoramiento: el enamorado verbaliza sus sentimientos ya sea a través del monólogo interior o con la confesión de sus sentimientos a una persona de su entorno.

\section{QUINTA FASE: LA DECLARACIÓN}

Este es el instante en el que uno de los personajes verbaliza sus sentimientos hacia el otro. Deja de lado el lenguaje gestual para confesar a través de la palabra su enamoramiento. Ambos enamorados se confiesan su amor y se produce la unión.

Estas fases nos servirán de apoyo formal para analizar las diferentes tramas amorosas y percibir en qué medida los autores de ambas obras han omitido o amplificado el esquema por el que tradicionalmente se desarrollaba una trama amorosa, además de ver cómo adecuan el mito clásico a este esquema, distinguiendo qué partes

45. De Bruyne, E., Études d'esthétique médiévale, Genève, Statkine, 1946, vol II, p. 179. 
amplifican y qué partes suprimen en función de sus objetivos, a la vez que se despeja el carácter positivo y/o negativo de cada trama amorosa.

Analizando los fragmentos presentes en el Roman de Troie, cuya temática es el amor, vamos a observar cómo Benoît de Sainte-Maure sigue el modelo establecido para la declaración amorosa en la Edad Media, deteniéndose, en mayor o menor medida, en unas etapas o en otras. Podemos ver en esta fase un descubrimiento de lo que están sufriendo los protagonistas que en muchos casos no saben lo que les sucede: "la déclaration d'amour, de quelque façon qu'elle se produise, s'inscrit là aussi, dans le Roman Antique, à l'intérieur d'une représentation de l'inexprimable ou de l'inconnaissable dans certains cas 46 ".

El aspecto más significativo de la reelaboración de esta trama amorosa es la supresión, tal y como hace el autor anónimo de Enéas con Dido, de la venganza de su heroína, dejando sólo el saber y la belleza propios de los personajes femeninos de esta época, cristianizando la figura de una mujer que abandona su patria y su familia por amor. En el mito clásico aparece el abandono y la posterior venganza de Medea a Jasón, sin embargo en la novela medieval, tras la conquista de Jasón, el personaje de Medea queda relegado a un segundo plano y serán los dioses los que se ocupen de vengar la traición de Jasón.

\section{* PRIMERA FASE:}

En esta primera trama amorosa, la etapa del pensamiento aparece nada más encontrarse ambos protagonistas. Medea, sin ayuda de ningún dios, como en el caso de Dido, siente en ella materializarse el flechazo:

Quant ele certeinement sot Que c'ert Jason, mout par li plot (...) 
Mout l'aama enz en son cuer.

(V.1257-1261)

El autor nos indica que en el primer contacto con Jasón, inexplicablemente, nace en Medea la certeza del sentimiento del amor: primero lo expresa con el verbo plot pero, a medida que lo piensa, va ya designando ese sentimiento que ella experimenta con el verbo aama. Esta graduación en el empleo de las palabras nos indica el estado creciente del sentimiento del amor en Medea.

*SEGUNDA FASE:

En la segunda fase, la de la mirada, Medea sigue adoptando el papel principal al examinar a Jasón y, es a través de su mirada como Benoît de Sainte-Maure transmite una descripción idealizada del guerrero griego, mirada y belleza son palabras clave, significativas de esta fase:

$\mathrm{Ne}$ poeit pas a negun fuer

Tenir ses ieuz se en lui non:

Mout li iert de gente faiçon.

La forme esgarde de son cors:

Cheveus recercelez e sors

A, e beus ieuz e bele face

Mais des or crient trop ne li place,

Bele boche a e douz regarz,

Bel menton, bel cors, e beus braz;

Large e grant a la forcheüre,

$$
\text { (...) }
$$

Mout le regarde en mi la chiere;

Mout i a Medea ses ieuz 
Douz, frans, sinples e sans orgueuz;

Mout par le mire doucement;

Ses cors de fin amor esprent.

(V.1262-1278)

En esta descripción, poco detallada, en la que la adjetivación gira alrededor de "beau", observamos que Medea, como lo dice el autor a modo de conclusión, ses cors de fin amor esprent, se siente preparada para conquistar a Jasón. Sus palabras anuncian que es ella la que tomará la iniciativa, mientras que Jasón queda relegado a un segundo plano, pasivo, no apareciendo hasta que resulta evidente el enamoramiento de Medea, no sólo interiormente sino exteriormente. Jasón es el guerrero, y mostrará su valor y su coraje al conquistar el vellocino de oro:

Or i a torné si son cuer

Qu'el ne laira a negun fuer

Qu'ele n'en face son poeir

(V. 1285-1287)

*TERCERA FASE:

Después de reconocer los síntomas del enamoramiento, Medea necesita la confesión de sus sentimientos para liberarse del sufrimiento que le provoca su pasión. La confesión representa una de las etapas más destacadas y más recurrentes dentro de las tramas amorosas medievales:

Sovent esgarde e se porpense

Coment ele ait joie pleniere,

Quar destreite est a grant maniere;

Mout en dote le conmencier.

(V. 1296-1299) 
Por otra parte, vamos a ver que a pesar de tener ses cors de fin amor esprent, Medea sigue las convenciones sociales medievales según las cuales estaba mal visto que una mujer diera el primer paso confesando su amor. Su actitud sería juzgada negativamente por el lector medieval, cuando Medea tiene desde su aparición un carácter positivo.

A este respecto y con un acercamiento más minucioso, podemos destacar una reelaboración parcial del mito clásico a través de la actitud del padre de Medea. En efecto su padre, de forma indirecta, es el que provoca los encuentros entre los dos protagonistas, siendo cómplice inconsciente de la unión de su hija y Jasón. En el mito clásico, el padre exige a Jasón la realización de una serie de pruebas, sin embargo en la novela medieval estas pruebas quedan omitidas:

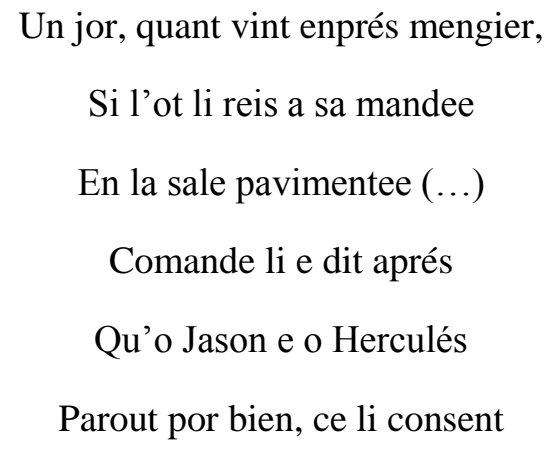

(V.1300-1307)

Es en este encuentro cuando se cumplen la cuarta y la quinta fase en la que Medea declara sus sentimientos a Jasón. En un primer momento, y por imposición de la mentalidad medieval sobre el comportamiento de la mujer, Medea se disculpa ante Jasón y le pide que no tome este acercamiento como una actitud impropia de las mujeres de su rango social, pero en una segunda etapa Medea confiesa directamente sus sentimientos hacia Jasón:

Mais, se de ce seüre fusse

Que je t'amor aveir poüsse,

Qu'a feme espose me preïsses, 
Que ja mais jor ne me guerpisses,

Quant en te terre retornasses

En cest païs ne me laisasses,

E me portasses leial fei (...)

(V.1407-1413)

A través de sus palabras podemos ver también cómo Medea es consciente de la función de reina que debe desempeñar en un futuro. Para la sociedad medieval y, según expone Georges Duby, ocho palabras latinas bastan para definir la perfección de lo femenino a los ojos del medievo: "pia filia, morigera conjux, domina clemens, utilis Mater. Hija, esposa, dama y madre a lo largo de toda su vida 47 ". Este es el papel que ha de desempeñar una mujer en una sociedad dominada por los hombres.

La unión entre Jasón y Medea se concreta a través del anillo que le ofrece la hechicera. Símbolo de unión y fidelidad, no sólo en la época medieval sino también en nuestros días, el anillo representará el compromiso por parte de la heredera de serle fiel al guerrero griego:

\author{
Or te bailerai mon anel \\ Si n'en verras ja mais plus bel \\ E si saches bien que la piere \\ Ne puet estre en niul sens plus chiere. \\ Soz ciel n'a home qui seit vis, \\ Des qu'il l'avra en son doit mis, \\ Qui ja puis crienge enchantement.
}

(V.1677-1683)

47. Duby, G., El caballero, la mujer y el cura, Madrid, Taurus, 1982, p. 19. 
Este anillo, símbolo de unión y compromiso, deja patente la idea de obstáculo para el héroe medieval. La mujer se convierte en uno de los obstáculos que debe superar el caballero para conseguir su empresa. Jasón debe abandonar a Medea para volver a su tierra con el vellocino: "ce type de femme merveilleuse se convertit en épreuve que le héros doit surmonter; ce qu'il réussit à la fin car il obtient que cette femme change sa nature négative d'abord par amour pour ce héros et ensuite par le biais des eaux purifiantes du baptême 48 ". Esta idea se ve apoyada con el sustantivo "prison" que define la situación de Jasón. Al exigirle el juramento ante su dios, Jasón se siente como prisionero y como tal buscará la libertad, libertad que encontrará al conseguir su objetivo como caballero: la Toison. El amor exigido no puede sino acabar mal al privar de libertad a una de las partes:

\footnotetext{
"Dame, fait il, ne quier guion

Se vos e ceste dame non.

S'en vostre prison me sui mis,

Ne m'en deit pas estre de pis."
}

(V. 1595-1598)

De este modo, y a través de la misma declaración resurge la faceta de caballero de Jasón, que ya hemos apuntado en el comienzo del análisis. Así al igual que a su señor, Jasón jura como hombre la lealtad a Medea, pero este juramento no tendrá mucha validez ya que en él está a priori el juramento que realizó como caballero.

Su faceta de caballero vuelve a estar justificada cuando se pone la armadura y sale en busca del vellocino; el acto de poner su armadura simboliza la vuelta del Jasón caballero frente al Jasón hombre protagonista de la trama amorosa: 
Lez le rivage, el sablonei,

Prist ses armes e sen conrei.

Primes chauça ses grenoillieres:

Ainc el siecle n'ot fait si chieres.

D'or fin furent si esperon,

Taillé de l'ovre Salemon.

Après a un ozberc vestu:

Onques mieudre forgez nen fu;

Taillez iert bien a sa mesure,

La maille en iert serree e dure;

Poi li pesa quant l'ot vestu.

Après laça un heume agu,

Resplandissant, de bone taille:

Ja por arme ne fera faille;

(V.1813-1826)

A pesar de surgir sin ayuda de ninguna intervención divina, el amor de Jasón se convierte en un intercambio; no surge de manera espontánea como el de Medea sino que nace a partir de un acuerdo para poder conseguir su objetivo: el vellocino de oro; sobresale en él el honor de caballero antes que el de hombre enamorado. Así, el autor a través del relato del mito del vellocino, exime de toda responsabilidad a Medea, quien al estar enamorada actúa bajo los impulsos del amor. Esta afirmación se apoya en el comentario que inserta Benoît de Sainte-Maure, atribuyendo a Jasón toda la culpa:

Trop l'engigna, ce peise mei;

Laidement li menti sa fei.

Trestuit li deu s'en corrocierent,

Qui mout asprement l'en vengierent

(V. 2039-2042) 
Podemos ver en el arrepentimiento de Jasón ante su promesa un anticipo de la tragedia de esta trama amorosa. Por otro lado, en su actitud ante la promesa, advertimos el reflejo de Eneas que al igual que él incumple la suya con Dido. Los dos hombres ponen por encima de su amor el deber de un buen guerrero. En este rasgo vemos la herencia del modelo de caballero que la canción de gesta proponía al público medieval:

\section{Ves ci l'image as dex des ciels \\ Je n'en vueil mie faire a jués \\ De mei e de vos l'asenblee;}

Par ce voil estre aseüree.

Sor l'image ta main metras

E sor l'image jureras

A mei fei porter e tenir

E mei a prendre sens guerpir;

\section{Leial seignor, leial amant}

Me seies mais d'or en avant.

Jason ensi li otreia,

Mais envers li s'en parjura:

Covenant ne loi ne li tint;

(V.1625-1637)

Con estos versos deducimos que Medea sospecha que su unión con Jasón no va a ser duradera; de esta forma intenta retener a Jasón por medio de la promesa de su amor ante la figura de Zeus dios supremo para la tradición clásica. Al introducir el culto de un dios clásico el autor medieval no intenta dar prioridad a los dioses paganos sino que, al contrario, evidencia la inutilidad de su culto a través del juramento fallido de amor eterno de Jasón. 
A través de las diferentes etapas desglosadas hemos podido observar lo que ya apunta Paul Zumthor: "dans ce type de tissu textuel le motif de la déclaration amoureuse s'exprime tant à travers la parole qu'à travers le geste, et même à travers l'objet trouvant le terrain propice pour s'insérer comme produit mais aussi comme producteur du sens $49 "$.

\subsubsection{MEDEA: LA MUJER Y EL AMOR}

La historia de Jasón y Medea no sólo adapta el mito del vellocino de oro innumerablemente tratado en la época clásica sino que, superpuestas al mito, Benoît de Sainte-Maure expone las etapas del enamoramiento al tiempo que ofrece una nueva imagen de Medea que se debate entre la razón y el amor, escogiendo fatalmente este último.

En este sentido vemos a través del estudio del personaje de Medea la adaptación del personaje femenino a la mentalidad medieval, otro gran logro de Benoît que modifica el personaje principal sin perder la esencia clásica, como expone Stefania Cerrito: "si l'adaptabilité d'un mythe aux différentes époques est une preuve de sa richesse et de sa fécondité, Medée occupe une place de choix parmi les personnages de l'Antiquité grecque dont le Moyen Âge a hérité. Par ses multiples et extraordinaires métamorphoses, elle a su garder sa modernité autour de tous les siècles médiévaux $50 "$

De esta forma, y siguiendo con el análisis de la trama amorosa, podemos ver también en esta historia la asociación del motivo tradicional tal y como lo reflejaba Ovidio: amour= maladie $_{51}$. Como dice Jean-Charles Huchet "l'amour médiéval est avant tout une taxinomie de symptomes. L'amour médiéval est avant tout une

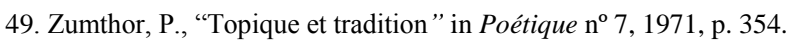

50. Cerrrito, S., "Les métamorphoses de Médée au Moyen Âge”, in Bien Dire et Bien Aprandre Revue de Médiévistique n 24, Lille, CEMD, 2005, p. 25

51. Harf-Lancner, L., Mathey-Maille, L., Szkilnik, M., Ovide méthamorphosé. Les lecteurs médiévaux d'Ovide, Paris, Presses Sorbonne, 2009, p. 11. 
symptomatologie et le discours qui en rend compte un discours médical 52 ". Esto se confirma en la siguiente cita donde el narrador nos expone los diferentes estados de Medea una vez que se da cuenta que está enamorada de Jasón:

\section{Ensi suffri a mout grant peine \\ Toz les oit jors de la semeine; \\ N'ot bien ne repos ne solaz. \\ Des or la tient bien en ses laz}

\section{Amors vers cui riens n'a desfense. \\ Sovent esgarde e se porpense \\ Coment ele ait joie pleniere,}

Quar destreite est a grant maniere

(V. 1291-1298)

Si en el mito clásico se nos presenta una Medea vengativa después de que Jasón la abandone, en cambio el autor medieval omite cualquier rasgo negativo presentándola como una mujer de gran belleza y sabiduría, ofreciéndonos una Medea que se corresponde con la nueva concepción de la mujer que poco a poco se estaba imponiendo en la Edad Media, más acorde con la concepción judeo-cristiana del perdón.

Ahora bien, el final de Medea no se desvía de la mentalidad cristiana que penaliza el suicidio, por ello el autor omite toda descripción de la muerte de Medea presente en la tradición clásica. "Le suicide, imposé par la tradition virgilienne, se justifie mal dans le cas d'un être aussi faible, mais il constitue de sa part un acte de suprême courage qui force l'admiration, une sombre admiration, teinte d'horreur et de pitié, pour cette damnée de l'amour 53 ". 
Grant folie fist Medea:

Trop ot le vassal aamé.

Por lui laissa son parenté,

Son pere e sa terre e sa gent.

Mais assez l'en prist malement,

Quar, si cum li auctors reconte,

Puis la laissa, sii fist grant honte.

(V. 2030-2036)

Por otra parte, y apartándonos de la propia trama amorosa, podemos destacar la visión del mito del eterno retorno dentro del relato de Jasón y Medea, a través del nacimiento de los guerreros a partir de los dientes del dragón. Podemos ver cómo el autor, influenciado por el mito de la creación del hombre, lo reproduce y hace que surjan hombres de la tierra y que mueran. Emerge en este fragmento un anacronismo muy señalado que nos transporta de la época clásica a la época medieval, ya que los guerreros van a nacer como auténticos caballeros armados medievales y destruirse; la vida y la muerte, etapas fundamentales en la trayectoria humana, quedan unidas en un mismo acto. La tierra se nos presenta como fuente de vida y al mismo tiempo de destrucción simbolizada por los guerreros que nada más nacer mueren:

Senpre verras o tes ieuz nestre

Des denz chevaliers toz armez

E de lur armes adobez.

En poi d'ore seront nascuz

E d'eumes, d' ozbers e d'escuz

Seront mout bien apareillé,

Mais mout seront entr'eus irié:

Veiant tes ieuz, s'entr'ocirront

Si tost cum il s'entreverront.

E doncs avras tot achevé.

(V. 1738-1747) 
Para concluir con este apartado subrayemos la nueva concepción del amor que se irá desarrollando durante los años posteriores, unida al tema de la mujer traicionada por amor y el del buen caballero. Así, reelaborando el mito, el autor no sólo ha adecuado los comportamientos de los protagonistas sino que, a través de estos personajes arquetipos, da una visión universal de ciertas actuaciones que permiten al hombre medieval aprender de ciertas acciones, llevando a cabo la intención didáctica de la literatura de esta época.

En cuanto a la intención literaria, el autor medieval, como hemos visto en el análisis del mito de Jasón y los argonautas, se centra en los dos grandes temas subyacentes al mito: el amor y la guerra. Deja de lado toda la carga mitológica del mito clásico y el origen divino de los protagonistas. Al adaptar el mito clásico, Benoît de Sainte-Maure reelabora una nueva concepción de la mujer dentro de la trama amorosa, en la que adopta el papel principal, dejando al personaje masculino a la trama guerrera, donde puede desarrollar las actitudes propias del hombre en la Edad Media.

Como nos dice Stefania Cerrito54, en la antigüedad greco-latina, pero también en la Edad Media, los diferentes autores se dividen entre los que transcriben parte del mito y los que lo adaptan totalmente. En este caso Benoît de Sainte Maure, por boca de Medea, nos expone las diferentes fases ya expuestas en la tradición del mito del vellocino de oro, transcribiendo las etapas fundamentales del mito clásico, amplificando solamente el episodio amoroso de ambos protagonistas y modificando algunos de los comportamientos de sus personajes principales.

No sólo observamos la transposición textual de un mito clásico en la obra medieval sino que vamos a ver cómo poco a poco se implanta la nueva mentalidad medieval que da un lugar destacado a la mujer, tal y como dice Georges Duby: “dans le domaine socio-politique, tout ce jeu d'amoureux a annoncé la réception favorable d'une nouvelle courtoisie et d'une nouvelle civilité pour les rapports hommes-femmes 55 ".

54. Cerrrito, S., op. cit. p. 41.

55. Duby, G., Histoire des femmes en Occident: Le Moyen Âge, Paris, Plon, 1991, p. 96. 
Además del reflejo de la evolución de la temática amorosa en el roman antique, esta trama nos muestra también el tema de la traición, muy tratado en la Edad Media. El personaje de Jasón lo encarna en su trama amorosa para no incumplir su deber de caballero; en este capítulo amoroso observamos otra forma de traición que efectúa el caballero: la traición a su amada. Tradicionalmente, en la Edad Media, se muestra la traición del vasallo a su señor, sin embargo en este episodio se trata de la traición de un caballero a su amada en aras de cumplir su ideal. Así se reutiliza una temática adaptándola a una nueva visión, propia del contexto socio-histórico que se refleja directamente en el texto medieval.

\subsubsection{PARIS Y HELENA: El AMOR PROHIBIDO}

Después del mito de Jasón y Medea, el siguiente en aparecer, partiendo de la temática amorosa de la que se ocupa el primer capítulo de nuestro estudio, es el de Paris y Helena. Este mito es sin duda el más importante de Troie y se convertirá en el tema central de la novela ya que, debido al rapto de Helena, se inicia la guerra y acontece la destrucción de la ciudad de Troya. En este apartado vamos a ver cómo el autor ha tratado la historia de Paris y Helena, cómo ha trasladado el mito clásico a la mentalidad de la época medieval y qué elementos ha omitido.

Recordemos el mito de Paris, más conocido como el Juicio de Paris, que comienza con la disputa de las tres diosas: Juno, Venus y Minerva. Príncipe troyano, Paris es el menor de los hijos de Príamo y Hécuba. Su destino trágico se remonta a su nacimiento. Cuando su madre estaba embarazada, tuvo un horrible sueño según el cual daba a luz una antorcha que causaría la ruina de Troya. Por eso, el recién nacido fue dado a un criado para que lo expusiera en el cercano monte Ida donde sería devorado por animales o perecería por otras causas; sin embargo, el niño fue rescatado por unos pastores que lo educaron como uno de ellos. Cuando alcanza una edad juvenil, se dedica a guardar el rebaño y es cuando se le aparecen las tres diosas. Paris fue elegido para decidir quién era la más bella. Juno le ofrece el poder sobre las tierras de Asia, Minerva le ofrece la victoria en las batallas y Venus le ofrece el amor de la mujer más bella de la Hélade, Helena, casada con Menelao, rey de Esparta. Paris elige a Venus como la más digna de recibir la manzana y, al elegirla, provocará la destrucción de su patria, Troya. 
La historia clásica de Paris ya le concede un destino trágico desde su nacimiento. Pero el mito clásico, tal y como lo hemos detallado, no aparece en la novela. A pesar de ser el tema principal de la novela, Benoît de Sainte-Maure no nos expone el mito del Juicio de Paris tal y como lo hace el autor de Enéas, desde las primeras páginas de su novela, sino que se centra en el desencadenante de la acción del rapto de Helena, dando preferencia a las consecuencias. El mito nos es presentado en forma de sueño que tiene Paris, dotándolo de un cierto matiz inverosímil: él mismo cuenta cómo se le han aparecido las tres diosas después de un día de caza:

Mout fist grant chaut d'estrange guise,

Ne venta gaires le jor bise.

Mes veneors e toz mes chiens

Perdi el val de Citariens.

Lez la funtaine ou riens n'abeivre,

De desoz l'onbre d'un geneivre,

M'estut dormir, nel poi müer

$$
(\ldots)
$$

Fu devant mei Mercurïon.

Celz treis deuesses m'amena,

Juno, Venus e Minerva.

(V.3865-3876)

Para Benoît de Sainte-Maure el relato mitológico carece de importancia y el autor se centrará en la amplificación de las numerosas batallas entre griegos y troyanos y en la descripción física de los guerreros más destacados. Sigue los pasos de la literatura épica anterior, adoptando los mismos mecanismos para desarrollar sus batallas y concediendo a sus héroes características de los caballeros medievales.

El resumen del episodio mitológico hecho por el personaje de Benoît, sin duda, contribuye a poner de relieve la intencionalidad del texto medieval, orientado a la individualización y ejemplaridad del personaje de Paris, dando así mayor amplitud y 
autonomía a la actuación del individuo frente a la adversidad, actitud más propia del género novelesco que del género épico.

Al despojar del impacto de toda intervención divina, el autor deja recaer toda la culpa de sus actos en el personaje principal, Paris, descrito como el anti-caballero que pone su amor por Helena, una extranjera, ante el amor por su patria, causando la destrucción de su ciudad.

A través de la unión entre Paris y Helena, se refleja la importancia que tiene el matrimonio en la sociedad medieval, siendo la concepción de esta institución la siguiente: "le mariage figure le lieu, où tous les discours constitutifs de la société médiévale se nouent en une "textualité" exemplaire plausible de toutes les approches critiques. Le mariage est avant tout une affaire économique réglant le report d'une génération à l'autre des biens immobiliers; il assure la pérennité des lignages et met un terme à l'errance des "jeunes" dont la revendication sexuelle et économique excessive fait peser une menace diffuse sur les "nantis" 56 ". Al no encajar en esta definición el perfil del personaje de Helena, ésta será seriamente juzgada por sus acciones.

No obstante, no toda la tradición clásica queda eliminada por el narrador medieval, en la medida en que "ses héros vont au temple comme on va à l'église; ils prient des dieux comme on rend hommage aux saints; les pratiques religieuses auxquelles il fait allusion relèvent de la coutume de la vie quotidienne, non de la vérité révélée $57 "$. Así nos presenta la mitología clásica de forma totalmente natural al incluir las prácticas religiosas en la vida cotidiana:

A ses privez dit e retrait

Qu'ele a pieça un vou voé

Rendrë a cest jor terminé.

Sor l'autiel vout ses dons ofrir

E uns devins respons oïr.

56. Huchet, J. Ch., Le roman médiéval, Paris, PUF, 1984, p. 223. 
Son erre fist apareiller,

Mout espleita del chevaucher.

Au temple vint o sa maisnee,

Mout par se fist joiose e lee.

(V. 4324-4332)

Benoît de Sainte- Maure se desprende de toda la carga mitológica del Juicio de Paris y, a partir de la llegada a Esparta de Paris, ya no hay ninguna alusión al mito; propone una nueva visión más acorde a la moral medieval, sin dejar de lado el mito clásico. El narrador reinterpreta el mito como una alegoría moral, una encrucijada entre lo ético y la fuerza de las pasiones, en este caso el amor prohibido por la sociedad, ya que Helena está casada con Menelao y tiene una hija. Aparte del adulterio, aparece en la figura de Helena lo que representa el amor para los autores medievales: la privación de la libertad, al aceptar a Paris, Helena es prisionera del amor que siente por él y al mismo tiempo pasa a depender del principe troyano.

El mito de Helena es el mito de la mujer infiel por excelencia; así, a través de la trama amorosa de Paris y Helena, podemos observar la reescritura de un mito clásico que refleja un comportamiento negativo, que provocará la destrucción de una ciudad y servirá al autor medieval para denunciar la conducta femenina. En las intervenciones de Helena aflora el sentimiento de culpabilidad; tal y como lo dice Frappier, en Helena observamos que «les victimes de l'amour cherchent à surmonter leur désarroi à trouver dans leur conscience une règle de conduite à sauvegarder leur volonté et leur liberté menacée 58 ".

Por ello, al apartarse del contenido mitológico clásico, Benoît de Sainte-Maure debe justificar ciertas actuaciones de sus personajes de forma racional. De este modo vamos a ver cómo el rapto de Helena no va a ser fruto de una promesa hecha por la diosa Venus sino que será fruto de la pasión que siente Paris al ver a la mujer de Menelao. En efecto, el autor omite cualquier referencia a la divinidad clásica, sin

58. Frappier, J., La poésie lyrique en France aux XII et XIII siècles, Paris, S.E.D.E.S, 1949, p. 239. 
embargo, la pasión de la que es la representante Venus, sí que está presente de una forma indirecta en las acciones del hijo de Hécuba y en las de la propia Helena.

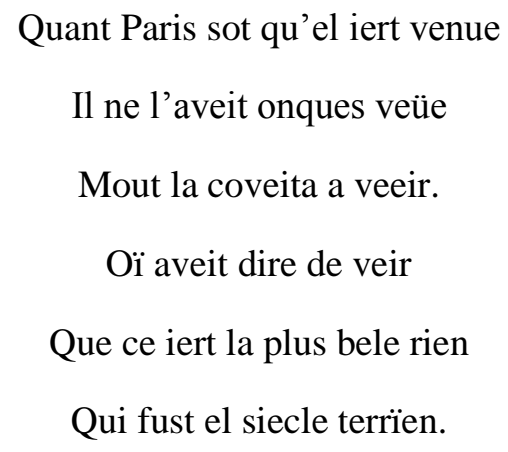

$(\mathrm{V} .4333-4338)$

Así, a pesar de la ausencia del mito clásico, la guerra de Troya queda argumentada de una forma racional. El narrador justifica la guerra como "la sollicitation de l'épouse égarée 59 ". Paris no va a buscar a Helena sino que va a vengar el rapto de su tía por los griegos; el rapto de Helena es el fruto de una vendetta muy común en la época medieval y no la recompensa de un juicio a la más bella. Al justificar racionalmente la guerra de Troya, el autor excusa la actitud de Paris:

Seignor, fait il, en cest païs,

Nos a li reis Prianz tramis

Por faire a ceus honte e damage

Qui le firent nostre lignage.

Ne sereit riens de m'ante aveir,

De ce n'aions ja niul espeir;

$$
(\ldots)
$$

Quant mener ne l'en porrïon

Por rien que faire poïsson,

Si nos convendreit engignier 
Els a laidir e damagier,

Que tiel chose puïsson faire

Dont il aient honte et contraire.

(V. 4383-4396)

El análisis del texto evidencia claras alusiones a la divinidad clásica del amor, causante del rapto de Helena, como recurso literario. Tal es el caso del templo de Venus que se encuentra en la ciudad de Helena, templo que será el lugar donde se produce el primer encuentro de los enamorados. Al situar el encuentro de los enamorados en el templo de Venus, el autor está identificando este amor como el "amor pasión", el que desencadena grandes tragedias, y se puede definir como "la personnification de ce désir qui bouleverse tous les obstacles et précipite l'héroïne vers la ruine et vers la mort 60 ”.

Citerea, ce dist l'autor,

Aveit a non l'isle a cel jor,

O il aancrerent lur nés;

Mout iert li tens douz e sués.

Un temple riche e merveillous,

Mout ancïen, mout precïous,

Aveit en cel isle, en l'enor

Venus, la deuesse d'amor.

Tuit cil del regne d'environ

I veneient a oreison.

(V.4257-4266)

Otra alusión a las divinidades clásicas se produce con la muerte de Paris en el templo de Juno. El final de esta relación supone la liberación por parte de Helena y el 
fin de la guerra de Troya. Al situar el cadáver en el templo de la diosa Juno, diosa despreciada en el juicio de Paris, pero diosa protectora del matrimonio, el autor deja vía libre a Helena para que vuelva con su marido legítimo. La relación empieza pues en el templo de Venus, divinidad con carácter negativo por representar a la pasión, y termina en el templo de Juno, divinidad que representa la razón:

\author{
La nuit se sunt esquergueitié \\ Mil chevalier riche e preisié. \\ Seveliz fu li cors Paris, \\ Dedenz le temple Junonis, \\ Si fetement qu'ainc fiz de rei \\ Ne fu si richement, ce crei, \\ Ne n'iert ja mes tres qu'a la fin.
}

(V. 22891-22897)

Recordemos, al respecto de esta dualidad que, según las teorías de la filosofía clásica, el alma humana está dividida en las tres partes que corresponden a los tres modos de vida o caminos que los hombres pueden elegir: la vida contemplativa que está representada por Minerva, la vida activa que está representada por Juno y la voluptuosa o placentera que representa Venus. Es Paris, como representante del hombre, el que voluntariamente elige la vida de placer al igual que Helena: los dos representan indirectamente a la diosa del amor, Venus.

En la reutilización del mito de Paris y Helena, fijándonos en la actitud de Helena, vemos cómo se plasma dicha dualidad en su comportamiento. Sus estados de ánimo son contradictorios y cambiantes, pasa de la aceptación de la pasión que siente, al escuchar la llegada de Paris, a la nostalgia y arrepentimiento por la infidelidad causada a su marido legítimo. Arrepentimiento y remordimiento también por ser causante de una guerra. A la salida de su patria, Helena es consciente del daño que provocará su decisión. En este caso, el autor medieval no exime de culpa a Helena como lo ha hecho con Medea. Vemos en la actitud de Helena, como dice Payen, "le remords, qui est la 
forme exaspérée du désespoir 61 ". En la siguiente cita, Helena, en un monólogo, expone sus remordimientos por ser causa de tanta destrucción:

Ja ne voussise estre engendree,

Ce peise mei que ainc fui nee.

En maudite ore comença,

En plus male definera.

$$
(\ldots)
$$

Que ne m'ocit li reis Prianz,

Qui par mei est vis confunduz

E que ses fiz li ai toluz?

Par mei se veit deseriter:

Molt me devreit bien desmembrer

Ecuba, dame, que fareiz?

De mei coment vos vengeriez?

Toluz vos ai voz bels enfanz,

Les prouz, les riches, les vaillanz.

Ne fist dame tiel porteare,

Ne fust dolerose aventure.

(V. 22953-22972)

Helena demuestra su malestar, y su mala fama le sobrevivirá haciendo que "ce n’iert mie nus hom vivanz" (v. 22961) se apiade de ella. Su elección no sólo la ha hecho desgraciada ahora, sino que perdurará en el tiempo; su nombre será sinónimo de destrucción, por eso pide en varias ocasiones su propia muerte tal y como ella la ha causado en tantos otros.

61. Op. cit., p. 9. 
En cambio, en el mito clásico, la actitud de Helena es disculpada por la intervención de una divinidad; no es la propia Helena la que realiza libremente el adulterio, sino que es Venus la que lo provoca. En la Helena de Benoît se ve materializada la imagen negativa de la mujer ya que es ella misma la que actúa sin la influencia de ninguna diosa. El narrador medieval no hace ninguna alusión a Venus en el encuentro entre Paris y Helena, sólo al templo que la simboliza: impone así a Helena como modelo de la mujer adultera, y culpable de sus acciones.

Su comportamiento negativo, tan criticado por Benoît de Sainte-Maure, se ve acentuado aún más cuando el autor la compara a otras mujeres que, como ella, han sido separadas de sus maridos. Dentro de esta pluralidad, Helena descubre el error de su conducta y comienza entonces a aflorar el arrepentimiento:

\footnotetext{
Ne la poeit nus conforter

Quant les dames veeit plorer,

Qui esteient o li ravies.

Mout ameient peti lur vies

Quant lor seignors veeient pris,

Auquanz navrez, plusors ocis;

Par poi li cuer ne lur parteient.
}

(V. 4649-4655)

La figura del personaje de Helena es una simple moneda de cambio, despojada de cualquier carga mitológica heredada del mito clásico. Lo que realiza el autor de Troie, es sugerir una nueva lectura del mito clásico en una clave más moderna, insertando la mentalidad cristiana y proponiendo modelos de conducta. En esto reside la función social del mito: en la recuperación de la imagen de Helena, podemos ver el tratamiento que se le daba a la mujer en la Edad Media.

Aparte de la castidad, la devoción y la caridad piadosa, cualidades requeridas por los ideales femeninos, los rasgos más reiterados son la prudencia, la discreción y la sensatez. Remiten al ideal de la mesura, que se propugna tanto para reyes y caballeros 
como para las mujeres 62 , cualidades que, de hecho, no poseen ninguna de las dos mujeres analizadas en las tramas amorosas.

Helena no representa esos ideales sino el de la belleza divina y la imagen tradicional de todas las mujeres. Su belleza, tal y como la describe el narrador medieval, justifica la atracción fatal de Paris. En la figura de Helena podemos ver la similitud con la diosa Venus aunque no se explicita; la pasión nace y se cumple en ella, por lo que es fiel representación de la divinidad clásica, que queda reflejada en el último verso:

D’Eleine, qui iert lur seror,

\section{De trestotes biautez la flor,}

De totes dames mireor,

De totes autres la gençor,

De trestotes la soveraine

Ensi come colors de graine

Est plus bele que autre chose

E tote ausi come la rose

Sormonte la biautez Heleine

\section{Tote rien qui nasqui humeine.}

(V. 5119-5130)

Mujer fatal, Helena personifica una serie de pasiones: la seducción, la sexualidad, el adulterio, la infidelidad a su familia y a su patria. Como muchas de las mujeres presentes en las obras medievales, el personaje de Helena está fundado en esa apariencia de belleza maléfica que genera conflictos y desastres. Representa a la vez el símbolo de una guerra justificada y a la vez lo absurdo de ella 63 .

62. Beceiro, I., De la Edad Media a la Moderna: Mujeres, educación y familia en el ámbito rural y urbano. Modelos de conducta y programas educativos para la aristocracia femenina siglos XII-XV, Málaga, Atenea estudios sobre la mujer, 1999 , p. 57.

63. Bronze, M., op. cit, p. 131 
Por otra parte, esto no impide que el personaje femenino de Helena se nos presente con ataduras sociales. El hecho de que el autor la defina como mujer casada y con una hija, hace de su adulterio una ofensa muy grave en la Edad Media. Al igual que Dido en el Roman d'Enéas, ha adquirido unas ataduras y responsabilidades con el matrimonio que sólo se pueden romper con la muerte. Contrastando con otra figura mítica femenina, la de Penélope, podemos ver en Helena a una mujer que cae en la tentación de la pasión que le provoca Paris, en ausencia de su marido Menelao.

\subsubsection{HELENA O EL AMOR CULPABLE}

$\mathrm{Si}$, como hemos visto, aparece Helena como figura negativa femenina dentro de esta segunda trama amorosa, a priori cabía una doble interpretación: Helena, como agente activo en la seducción de Paris, debido a su belleza, o bien como víctima de los deseos de una diosa. El autor medieval escoge deliberadamente la primera opción, que le permite no sólo evidenciar su misoginia sino también exponer el modelo de mujer que se guía por la pasión, modelo de conducta errónea para las mujeres de la Edad Media:

Mout est isnele Renomee:

Saveir fist tost par la contree

Que Paris iert ovoc ses nés

Iluec en l'isle au port remés.

Eleine en oï la novele, Qui sor autres dames iert bele:

$\mathrm{Ne}$ vit nus hon plus avenant.

Ne se prise ne tant ne quant,

Se ele a la feste ne vait.

\section{A ses privez dit e retrait}

Qu'ele a pieça un vou voé 


\section{Rendrë a cest jor terminé.}

(V.4315-4326)

No sólo la trama amorosa de Paris y Helena va a ser negativa porque destruye la propia patria sino porque según el tratado de amor de André Chapelain incumple la tercera regla "alterius idonee copulatam amori scienter subvertere non coneris 64 ". Recordemos que Helena fue entregada por su padre a Menelao, con lo cual su unión es totalmente legítima a los ojos de la mentalidad medieval.

Con relación a esa regla, Helena nos es presentada con un carácter negativo claramente marcado, que la acompañará hasta el final de la novela. Pero también, como consecuencia de su elección, se debate entre la ambivalencia del “deber" y el "querer", provocando en ella los mismos sufrimientos que los que su actitud provocará en Troya y en sus habitantes:

Dame Heleine faiseit senblant

Qu'el eüst duel e ire grant.

\section{Fortment plorot, grant duel faiseit}

E doucement se conplaigneit.

Son seignor regreteit fortment,

Ses freres, sa fille e sa gent,

E sa lignee e ses amis,

Esa contree e son païs,

Son bel seignor e sa richece,

E sa biautié e sa hautece.

(V.4639-4648)

64. Chapelain, A., De amore, Barcelona, El festin de Esopo, 1985, p. 157 ("No intentes destruir a sabiendas el amor de una mujer unida rectamente a otro"). 
Se manifiesta en ella la conciencia ética y el no querer enmendar su error, ya que permanecerá en Troya hasta la victoria griega: pasa de la aceptación de la pasión al arrepentimiento y finalmente al sometimiento, aceptando formar parte de la familia de Paris de forma legítima. En la siguiente cita vemos cómo lamenta la muerte de Paris junto a la hermana de éste, Casandra:

Dame Heleine ne s'est pas feinte:

De dolor a la color teinte,

Ses chevels a ronpuz e treiz,

E sovent gete criz e breiz:

N'i a nule qui plus en face.

Lermes li fundent sor la face,

Si que la peitrine a moillee.

Tiel dolor a e tiel aschee,

Se morte fust, ce li fust bel;

Molt l'an prisent viell e danzel,

E molt l'en sorent puis bon gré

Li plus prochein del parenté.

(V.16479-16490)

Desde un punto de vista objetivo, Helena, y más concretamente su rapto, resulta ser la causa de la guerra de Troya. En el mito clásico podemos ver, como Jean-Louis Backès que une a Helena con Venus, limitando así su culpa, que “c'est à la fois lui permettre de se considérer comme une victime et proclamer qu'elle est en contact avec le sacré 65 ". Sin embargo, este elemento sagrado que confiere el mito clásico a Helena es totalmente borrado de la obra medieval que denuncia esa culpa y sus consecuencias.

De hecho, para el mito clásico la verdadera culpable es Venus que se sirve de un mortal, Paris, que, al pertenecer a la raza humana posee todos sus vicios. Y eso para 
lograr su objetivo: brillar por encima de las otras dos diosas y erigirse como la más bella. Sin embargo el autor medieval remodela el mito para que sea la mujer la culpable.

En efecto, eliminando todo tipo de referencia mítica, el narrador deja reposar toda la culpa en Helena, ejemplo de mujer que ha actuado ciegamente por el deseo, y que reconoce su culpa y se arrepiente:

Plus vos amöe que mon cuer:

Ce ne puet estre a nis un fuer

Qu'aprés vos remaigne en vie.

A Mort pri gié qu'ele m'ocie.

Ja plus terre ne me sostienge

$\mathrm{Ne}$ ja mes par femme ne vienge

Si grant damage cum par mei!

Tant riche duc e tant bon rei

E tant riche amiraut preisié

En sunt ocis e detrenchié!

Lasse! Por quei fui onques nee

Ne por quei oi tiel destinee

Que li monz fu par mei destruit?

Bien engendra estrange fruit

Mis pere en mei, quant jo conçui!

(V. -22923-22937)

A lo largo de toda la novela, a través de algunos discursos que ilustran los distintos ánimos de Helena y atestiguan la posición y la intención del autor medieval, podemos ver cómo éste intenta provocar la aceptación por parte del lector de la culpa atribuida al personaje femenino de Helena, como única culpable de la destrucción de Troya: 
* Helena enamorada:

Quant Paris sot qu'el iert venue

Il ne l'aveit onques veüe

Mout la coveita a veeir.

Oï aveit dire de veir

Que ce iert la plus bele rien

Qui fust el siecle terrïen.

Tant fist, tant dist, tant porchaça,

E tant revint e tant ala

Que il la vit e ele lui.

Mout s'esgarderent anbedui.

El ot demandé e enquis

Cui fiz e dont esteit Paris.

Fiere biautié en lui mirot:

Mout l'aama e mout li plot.

(V. 4333-4346)

*Helena arrepentida:

«Sire, fait el, ne sai que dire,

Mais assez ai e duel e ire:

N'en puet aveir niulle riens plus.

Se je desdi e je refus

Vostre plaisir, poi me vaudra;

Por ce sai bien qu'il m'estovra,

Voile o ne voille, a consentir 


\section{Vostre buen e vostre plaisir."}

(V.4755-4762)

Estos versos ilustran el cambio de actitud de Helena con respecto a Paris: del enamoramiento al arrepentimiento de una mujer que desea volver con su marido legítimo. El arrepentimiento de Helena es una actitud destacada por el autor no sólo por su infidelidad, casada con Menelao y madre de Hermione, sino por la función de reina que representa y que según la tradición medieval tenía que ser casta, prudente, discreta.

Por razones antropológicas, ligadas al sentimiento de pecado unido al personaje femenino, debido al dominio del pensamiento judeo-cristiano de la Edad Media, la tragedia de la mujer que se abandona a sus pasiones está ampliamente tratada en toda la literatura medieval y más concretamente en las dos obras objeto de nuestro estudio. En el estudio de los mitos que han pervivido en la literatura medieval, encontramos mujeres como Dido o Medea que se abandonan a los deseos de la pasión y tienen un final trágico, ejemplos de mujeres a las que la pasión ha llevado a la muerte o a la destrucción.

Cabe destacar que el mito clásico antiguo conlleva una idea de sumisión de Helena a los designios de la diosa Venus; sin embargo en la novela medieval, al estar despojada de parte de su carga mítica, Helena actúa de forma individual, perfilándose en ella una nueva actitud femenina lejana a la sumisión de un modelo masculino. Pues, Helena, al permitir su rapto, está rechazando su sumisión a su marido Menelao, del que depende según la mentalidad del s.XII.

También hay que señalar que, dentro del relato del amor de Paris y Helena, llama la atención el trato recibido por Helena: a su llegada a Troya es recibida como una auténtica reina. Rasgo que hace más negativo aún su comportamiento ya que causará la desgracia no sólo al bando griego sino también al bando troyano.

\section{Assez li a li reis pramis}

Qu'el sera dame del païs.

Tant chevaucherent, tant parlerent 
Que es rues de Troie entrerent.

Onques nus hon, a celui jor,

Si cum nos content li autor,

N'aveit oï anceis parler

De si grant joie demener

A niulle gent qui fussent vis,

Cum le jor firent, el païs.

La nuiz i fu mout celebree,

Mout eissaucee e henoree;

Mais l'endemain, a grant hautece,

O grant joie e o grant leece,

A Paris Heleine esposee.

(V.4851-4865)

Así, casarse con Paris significa incumplir su promesa hacia su marido Menelao, romper una unión legítima y traicionar a su familia. Única en darse cuenta del error cometido por parte de Helena, Casandra va a ser la que evidencie su mal comportamiento, que reconozca el horror y la destrucción marcada por el destino trágico de esta mujer que, llevada por la pasión de un amor ilegítimo, ha sido causante de una guerra. Reformulando el mito, Benoît cumple con la mentalidad judeo-cristiana de su época, condenando y castigando el comportamiento de la mujer adultera:

Eleine fu mout henoree

E mout joïe e mout amee

Del roi Priant e de sa femne

E de toz les autres del regne.

Li frere Paris l'orent chiere

E ses serors, a grant maniere,

Fors la devine Cassandra,

Qui mout grant noise demena: 
Qui qu'onques fust liez ne joios,

Ele faiseit duel angoissous.

A haute voiz a toz diseit

Que tot certainement saveit

Qu'or sereit Troie desertee,

Ja ne sereit mais rabitee:

Mout en esteit la fins procheine.

$(\mathrm{V} .4877-4891)$

Por otra parte, la repetición de los insultos y reproches que asignan los griegos a su antigua reina no hace más que resaltar la negatividad y apoyar la idea del arrepentimiento en un intento por enmendar su actitud equivocada. El autor hace que Helena se arrepienta de sus acciones para poder lograr el perdón no sólo de su marido sino también del lector, que sólo así puede disculpar su actitud:

Vengiez vos tost, por Deu, de mei:

Ne voil plus vivre ne ne dei.

Del cors me traient les mameles

Dames, meschines e puceles,

Qui par mei ont perdu lor joie!

En la noble cité de Troie,

Lasse, mar me virent venir!

Ja ne deüssent consentir

Li deu ne la mers ne li vent!

$$
\text { (...) }
$$

Au mien voille sa cumpaignie.

Ja sui je vostre douce amie,

Cele qui por vos se forsene,

Qui riens ne conforte n'asene, 


\section{Cele qui ainc ne vos fist tort,}

(V.22977-22996)

Además, si consideramos este relato mítico desde otro punto de vista, siguiendo la mentalidad de la caballería en la Edad Media, la guerra de Troya ilustra no solo lo que hemos analizado anteriormente sino también "la parfaite illustration du conflit entre ces deux catégories de chevaliers. Menelaus, en essayant de reconquérir par les armes une épouse ravie par le "jeune" Paris, défend les droits des hommes établis qui ont grâce au mariage abandonné l'errance propre de la "jeunesse" 66 . De hecho no sólo se subraya el carácter negativo de la mujer sino también el carácter irreflexivo de Paris que representa al caballero joven que no piensa en las consecuencias del rapto de una mujer casada, oponiéndose así una vez más el senior al junior.

También, en esta trama, como en la de Medea y Jasón, hemos podido ver cómo el ideal amoroso en la Edad Media está asociado estrechamente a la muerte, ya que no sólo implica satisfacción y alegría, sino que la mayor parte del tiempo los enamorados sufren y soportan los sufrimientos infligidos por la pasión/amor. En las dos tramas amorosas que hemos analizado, tanto Medea como Helena abandonan a su familia, influenciadas por la pasión, para cometer acciones que las llevarán a una a la muerte y a otra a la destrucción de una ciudad.

Como conclusión al análisis de esta última trama amorosa, podemos ver en la reescritura de este mito, como Mircea Eliade, que "la connaissance des origines et de l'histoire ancienne dérive, en dernière instance, de l'importance accordée à la connaissance des mythes "existentiels" et "historiques", des mythes relatant la constitution de la condition humaine 67 ". En este sentido, hemos podido encontrar en la transposición de los mitos una respuesta a ciertos comportamientos humanos y, en definitiva, al adaptar a un nuevo contexto socio-cultural el mito clásico, Benoît de Sainte-Maure otorga a su "reescritura" el significado ejemplar que encierra todo relato mítico, como modelo / espejo de la condición humana.

66. Huchet, J.C., Le roman médiéval, Paris, PUF, 1984, p. 28.

67. Eliade, M., Aspects du mythe, Paris, Gallimard, 1963, p. 114. 
A través del análisis de estos dos pasajes mitológicos y de otros que analizaremos a lo largo de nuestro estudio, comprobamos lo que ya expone JeanCharles Huchet respecto a la transcripción de los mitos clásicos en la literatura medieval: “écrire, c'est donc toujours réécrire afin de cerner un secret antérieur, le déplier tout en le déplaçant, le dire et le taire à la fois, mieux le refouler pour qu'il conserve son mystère, sa force de sollicitation, et incite à lutter pour l'écriture contre son retour 68 ».

\subsubsection{TROILO Y BRISEIDA}

Siguiendo con el corpus de mitos relacionados con el tema amoroso en Troie, la trama amorosa de Troilo guerrero del bando troyano y Briseida hija de Calchas, aparece en tercer lugar (V.13261-13866), proponiendo también un análisis de la actitud negativa femenina frente al amor, pero aportando una variación con relación a las anteriores. En efecto, si los personajes presentes pertenecen a la mitología, en esta trama amorosa es insertado un tercer personaje masculino, totalmente inventado por el autor medieval, Diómedes guerrero del bando griego, que va a sufrir todos los síntomas hasta ahora reservados a los personajes femeninos. Al igual que Lavinia en Enéas se siente confuso al experimentar por primera vez el amor, se siente desorientado, extraño al percibir los síntomas amorosos.

Bele, fait sei Dïomedés,

Onques d'amer ne m'entremis,

N'amie n'oi ne fui amis.

Or sent qu'Amors vers vos me tire.

Qui vostre grant biautié remire,

N'est merveille se il esprent.

(V. 13556-13561)

68. Op. cit. p. 11. 
Se perfilan aquí las nuevas tendencias literarias en las que el hombre deja de lado su carácter de caballero en busca de nuevas tierras y comienza a desarrollarse como hombre en busca del amor. La sentencia tan característica de los cantares de gesta "à l'homme la guerre, à la femme l'amour 69 "queda en esta trama anulada, y el hombre tiene el mismo papel que la mujer.

En efecto, el análisis nos muestra cómo el autor, a diferencia de las dos tramas estudiadas, invierte los papeles de los enamorados y es Troilo primero y Diómedes después los que van a confesar sus sentimientos a Briseida. Al invertir los papeles propios de las mujeres y los hombres, el autor da un carácter negativo a la trama amorosa. Veamos dos discursos significativos:

*Declaración de Troilo cuyo nombre se asemeja a la devastada Troie, y que va a correr la misma suerte en el amor:

"Bele, fait il, or vos en pri, S'onc m'amastes, or i pareisse!

Ne vueil que nostre amors descreisse:

De meie part vos di je bien

Qu'el n'apeticera de rien.

Mon cuer avreiz toz jorz verai,

Por autre ne vos changerai."

(V. -13504-13510)

** Confesión de Diómedes:

69. Akkari, H., «La déclaration amoureuse de l'héroïne dans la chanson de geste ou pour une autre poétique amoureuse» in Bien Dire et Bien Aprandre Revue de Médiévistique nº 15, Lille, CEMD, 1997, p. 7. 


\section{«Tant sachez bien certeinement \\ Qu'en vos metrai mon bon espei \\ Je ne quier mes grant joie aveir \\ De ci que j'aie segurance \\ D'aveir vostre amor sans dotante, \\ E que j'aie vostre solaz \\ Si fetement qu'entre mes braz \\ Vos beis e oilz e boche e face."}

(V. 13562-13569)

En esta trama amorosa, donde el autor despliega todo su ingenio, la mujer va a aparecer como personaje secundario, vinculado a la idea de mujer como posesión, siempre unida a un hombre, primero a Troilo y después a Diómedes. Briseida, al no haberse casado con su amante Troilo, depende de su padre que la reclama como a un objeto:

Calcas ot dit Agamennon,

As autres reis, a Thelamon,

Qu'il la demandassent Priant.

Ne voleit pas d'or en avant

$\mathrm{Qu}$ ' ele fust plus en lor comune,

Car trop les het, ce siet, Fortune.

Si ne vuelt pas qu'o els perisse;

En l'ost a lui vuelt qui s'en isse.

Ceste requeste fu bien fete;

Mainte parole i ot retrete.

(V. 13091-13100)

Por otra parte, tras separarse de Troilo, Briseida suplica la muerte por no poder estar al lado de su amado. Al manifestar su deseo de morir promete a Troilo amor eterno, sin embargo contrasta el lamento por su marcha con la manera de vestirse para 
ser recibida por el bando griego; Briseida se viste de forma muy elegante y fastuosa para volver con su padre Calchas. Esta actitud será el anticipo de todas las actitudes siguientes de Briseida, las de una mujer que ostenta todas las cualidades que Benoît de Sainte-Maure denuncia, con un carácter claramente inconstante:

\footnotetext{
Femme n'iert ja trop esgaree:

Por ce qu'ele truist o choisir,

Poi durent puis li suen sospir.

A femme dure duels petit,

A un oil plore, a l'autre rit.

Molt müent tost li lor corage,

Assez est fole la plus sage:

Quant qu'el a en set anz amé,

A ele en treis joz oblié.
}

(V.13438-13446)

El autor aprovecha esta trama para realizar una descripción dicotómica de mujeres: el tipo negativo cuyo comportamiento es totalmente rechazado, debido a su mentalidad cristiana, y el positivo en mujeres muy escasas y difíciles de encontrar. Recordemos que la mentalidad medieval imponía un ideal moral a las mujeres, resumido en las ocho $_{70}$ palabras que aplicamos en el estudio de la trama de Jasón y Medea. Papel que ha de desempeñar una mujer en una sociedad dominada por los hombres, siendo un objeto de gran valor por la ventaja que pueda procurar: hijos, tierras, poder.

Siguiendo con la concepción de ideal femenino medieval, la belleza también podía ser para Benoît de Sainte-Maure fuente de amoralidad ya que, como primera cualidad que sobresale en las mujeres, es utilizada para el engaño y la artimaña. Así se plasma en esta trama con la actitud cambiante de la bella Briseida que provoca el sufrimiento de dos hombres.

70. Duby, G., op. cit., p. 19. 
Por eso, esta trama reviste un carácter completamente negativo, no sólo debido a que Briseida engaña a Diómedes sino también por la unión anterior con Troilo al que le ha jurado amor eterno. En este episodio Diómedes aparece como un amante primerizo que, debido a su inexperiencia, no sigue los pasos fijados en la declaración amorosa y es él, el que confiesa su amor a su amada, cuando el ideal de caballero medieval suprimía todo tipo de acción en el amor, priorizando la valentía y proezas guerreras:

Quant Amors vout qu'a vos m'otrei,

Nel contredi ne nel denei.

A son agré, a son pleisir

Li voudrai mes des or servir.

De vos me rendra guerredon:

Je ne l'en quier nul autre don,

E se a ce ne m'atendeie,

Ja de bon cuer nel servireie.

(V.13691-13698)

A pesar de la actitud negativa de Briseida como mujer, el autor da un rasgo positivo a la hija de Calchas al ser ella quien le recuerda a su padre el ideal de caballero y lo deshonroso de su conducta. Pero la actitud del padre de Briseida está justificada por las fuerzas divinas, que le empujan hacia su destino, y que, junto con el amor, impiden a los hombres ser totalmente libres y actuar según sus propias convicciones. Su actitud queda pues disculpada por lo involuntario de sus actos, no así la de su hija:

Puis qu'Apollo le commanda.

$\mathrm{Ne}$ fis mes rien si a enviz:

Je n'en dei mie estre honiz,

Car se il fust au mien talant,

Cest huevre alast tot autremant.

Riens ne siet mie la dolor 
Qu'en soefre mis cuers nuit e jor.

(V.13788-13794)

Sin embargo, como su padre, Briseida, incumple su promesa de lealtad, hacia su amado, y actúa como él traicionando a su patria. Se puede ver en la hija de Calchas el espejo del padre, ambos traidores de su pueblo. Ahora bien, sus remordimientos no son porque haya traicionado a su amado sino por su gloria y su honor, valores propios del ideal de caballero en la canción de gesta:"Lors donc que Briséida apprend que son père exige d'elle qu'elle quitte la ville de Troie au plus vite, sa première pensée n'est pas qu'elle va se retrouver à jamais séparée de son amant Troïlus, mais qu'elle va devoir vivre seule et sans appui au milieu d'une armée étrangère 71 ".

\footnotetext{
“De mei n'ert ja feit bon escrit

Ne chantee bone chançon.

Tel aventure ne tiel don

Ne vousisse je ja aveir!

Mauvez sen oi e fol saveir

Quant je trichai a mon ami,

Qui ainc vers mei nel deservi.

Ne l'ai pas feit si cum je dui:

Mis cuers deüst bien estre en lui

Si atachiez e si fermez

Que de mei fust toz jors amez.”
}

(V.20238-20248)

La actitud cambiante de Briseida se manifiesta hasta en su declaración de amor. Al ver a Diómedes herido, le confiesa su amor pero, al mismo tiempo, el narrador resalta esa actitud cambiante en un verso refiriéndose a Troilo: “Car rien sozciel n'amai 
ainc plus" (V. 20340). Briseida siente en su propio cuerpo la indecisión de su amor; es consciente de ello y lo demuestra públicamente:

Ne puis müer que ne me plaigne

De ce dont je sui en error,

Car nule riens qui a amor,

La ou sis cuers seit point tiranz,

Trobles, doutos ne repentanz,

Ne puet estre sis cuers verais.

Sovent m'esjoi, sovent m'irais,

Sovent m'est bel, e bien le voil,

Sovent resunt plorous mi oil.

Ensi est or, je n'en sai plus.

(V. 20308-20317)

En paralelo, observamos por primera vez el enamoramiento en un hombre, a través de Diómedes que sufrirá los mismos síntomas que Medea o Helena:

Qui qu'ait sejor, repos ne bien,

Li fiz Tideüs n'en a rien,

Quar por amor est si destreiz,

Une ore est chauz e autre freiz.

Ne puet dormir n'il n'a l'oil clos,

Ne nuit ne jor n'est en repos;

Sovent pense, sovent sospire,

Sovent a joie e sovent ire,

Sovent s'irest, sovent s'esheite.

Amors li a fait tiel entreite

Dont la colors li change e mue. 
Par maintes feiz le jor tressue,

Que il n'a chaut ne qu'il nel sent

Tiel sunt li trait d'amor sovent:

Que il tient de rien ne enlace,

Sovent li fait palir la face.

(V.15001-15016)

Con relación a este padecimiento de Diómedes, queda ilustrada en esta trama, una vez más, la actitud negativa de la mujer, resumida en su inconstancia y confesada en el remordimiento por parte de Briseida al deshonrarse.

\subsubsection{AQUILES, EL NUEVO NARCISO}

La última trama amorosa que aparece en Troie es la protagonizada por Aquiles, ideal de caballero medieval, valiente y luchador que ilustra el enamoramiento masculino de una forma muy diferente, ya que su historia de amor está marcada negativamente desde el principio.

Héroe griego, se enamora de la hermana de Héctor, su gran enemigo, al que ha asesinado. En él está la dualidad: por un lado, está enamorado de una troyana y por otro lado tiene el deseo de venganza hacia los troyanos. Su dilema y contrariedad se acentúan al ser Policena troyana, pero sobre todo hermana del que él ha matado.

Tres son los autores clásicos que trataron esta trama amorosa: Eurípides, Séneca y Ovidio. Cada uno, de una forma diferente, resalta lo mortal de este episodio para ambos amantes. Aquiles, hijo del rey de los Mirmidones, sobrepasa a todos en belleza, valor y buen juicio. Sin embargo comete el error de creerse a salvo de las flechas de Cupido y así es cómo su destino se asemeja al de Narciso, cuyo mito es el siguiente: marcado por un oráculo del adivino Tiresias a su madre Liríope, la ninfa azul, madre de Narciso; castigo dado por Némesis, bajo petición de los amantes despechados. Así la 
maldición, "sic amet ipse licet, sic non potiatur amato 72 ", provoca que Narciso se enamore de su propia imagen al verse reflejado en el agua.

Llama la atención el paralelismo con Narciso que anuncia así el trágico final de la existencia de Aquiles. Ese mito ha tenido numerosas interpretaciones, entre las cuales destaca la interpretación moralista, en la que se evidencia el castigo por la soberbia de Narciso al no querer dar curso al fluir natural del enamoramiento y la sexualidad, y no ceder a su vivencia en pareja. Se le da en este sentido un valor de "fabula alegórica" con fin didáctico-moralizante. El autor en la obra medieval intenta demostrar que hasta el más valeroso guerrero puede caer en las manos del amor. Vemos en la actitud de Aquiles numerosas semejanzas con la actitud del Narciso clásico, tal y como lo expone Ovidio en Las Metamorfosis; Narciso al igual que Aquiles se da cuenta de su trágico final: ¡Ese soy yo! Ya me he dado cuenta y ya no me engaña mi imagen; ardo en amor de mi mísmo, a la vez provoco y sufro más llamas (...) Y no es dura la muerte para mí, que con la muerte voy a librarme de mis sufrimientos; el que yo amo es el que quisiera que fuese más duradero; pero siendo así, los dos moriremos unidos en un solo aliento $_{73}$ ". Para ambos la solución a su dolor es la muerte:

“Ha!Las, feit il, tant mar i mui!

Tant mar alai veeir les lor!

Tant mar il vi la resplendor

Dont mis cuers sent mortel dolor

E main e seir e nuit e jor!"

(V.17638-17642)

Como Narciso, Aquiles arde cada vez más y se consume por dentro al desear tanto y no poder lograr obtener lo que anhela fervorosamente:"Achille se compare à Narcisse amoureux non seulement de son "ombre" (c'est-à-dire de son reflet), mais

72. Ovidio, Metamorfosis, Madrid, Alianza, 1995, p. 37.

73. Ibid., p. 57. 
aussi de sa mort, tout amour impossible étant une figure de la mort à laquelle il ne peut manquer de conduire 74 ".

Desde el primer momento las alusiones a la muerte son constantes en la trama amorosa. No sólo la comparación implícita con Narciso sino también los sentimientos que provoca en él Policena llevan a Aquiles a pensar en su trágico final y a debatirse entre el amor y la venganza. Sólo contemplar a su amada le provoca "freidure e glace", metáfora de la muerte inmediata del protagonista:

\author{
N'a rien sor li qu'il ne retraie; \\ El cuer li a feit mortiel plaie. \\ La resplendor qu'ist de sa face \\ El cors li met freidure e glace. \\ Sis nés, sa boche e son menton \\ Le resprenent de tiel arson \\ Dom ardra mes dedenz lo cors: \\ Pinciez sera d'Amors e mors.
}

$$
\text { (V. 17561-17568) }
$$

Como el que ha sido picado por un mortal aguijón, Aquiles "onques ne remua ses piez" (v.17602). En un momento de lucidez, expone lo confuso y fatal de su amor y las consecuencias de sus actuaciones irreflexivas que lo llevaran a la muerte. A través del monólogo del protagonista, el autor expone lo equivocado de su actitud y las consecuencias del amor. El monólogo es el mejor recurso para dejar ver el sufrimiento de Aquiles en el amor, que es la peor de sus batallas:

Sovent mue color sa face:

Une ore est pale, autre vermeille.

A sei meïsmes se merveille

Que ce puet estre qui il sent,

74. Payen, J- Ch., Le motif du repentir dans la littérature française médiévale, Genève, Librairie Droz, 1967, p. 301. 
Qu'ensi freidist e puis resprent.

Sempres li estreint si le cuer

Qu'il ne se meüst a nul fuer

Tant cum il la poïst choisir;

Del cuer li issent lonc sospir.

(V. 17606-17614)

$\mathrm{Su}$ actitud de guerrero no le impide enamorarse y comportarse de manera totalmente opuesta. Sus proezas son innumerables y su liderato se explicita en batallas descritas en numerosos versos. Pero pronto Aquiles dejará de obrar como un caballero valiente; así se lo reprochan sus compañeros que subrayan sus cualidades de caballero para hacerle ver su actitud errónea:

Dont dist Thoas: “Avoi! Avoi!

Sire Achillés, vous dites mal.

Tant par estes preus e vassal,

Ne doit de vostre bouche issir

N'ueuvre loer ne consentir

Ou point aiez de dehonnour.

Sor touz vaillans avez valour

E pris e honneur e proesce:

N'abessiez pas vostre hautesce,

Ne maumetez ce qu'est en vous.

(V. 18256-18265)

La trama amorosa comienza al igual que todas las anteriormente analizadas: con la visión de la mujer amada. El brillo que emana de Policena la hace más preciada y bella para él. Inmediatamente, y sin pensar en sus orígenes, Aquiles, como nos expone Benoît de Sainte-Maure, "L'a cuit el cuer de l'estencele /Qui ja par li nen iert esteinte" (17554-17555). Policena, tal y como nos la describe el autor, cumple con los cánones de 
belleza medieval: piel clara, pelo rubio, ojos brillantes. Su gran belleza es la que empuja al guerrero griego a amarla de un amor sincero:

\section{La grant biautié e la faiçon}

Qu'Achillés vit en la pucele

L'a cuit el cuer de l'estencele

Qui ja par li nen iert esteinte.

En son cuer l'a descrite e peinte:

\section{Ses tres biauz oilz veirs e son front, \\ E son biau chef qu'el a si blont}

Que il resenble estre dorez,

Totes denote ses biautez.

(V. 17552-17560)

Todo le causa daño, hasta mirarla le produce quemaduras. Queda patente una representación más del amor-pasión, la llama: "sis nés, sa boche e son menton / Le resprenent de tiel arson" (V. 17566). No sólo resulta afectada su salud sino también su faceta de caballero: el amor lo despoja del valor y la proeza guerrera, convirtiéndole en un simple hombre que se deja llevar por sus pasiones. El amor lo inmoviliza y lo arroja hacia su trágico final. Y el autor denuncia explícitamente la fuerza del amor y la irracionalidad del personaje enamorado:

Quant cil li tolst sens e mesure,

Quil ne garde loi ne droiture,

Noblesce, honnesté ne parage.

Vers Amour, qui puet estre sage?

Ce n'est il pas ne ne puet estre:

En Amour a trop greingnour mestre

E trop par lit forte leçon.

(V. 18445-18451) 
Policena, como causante de la desgracia de Aquiles, estará siempre presente en los pensamientos de éste y así lo demuestra la estatua edificada en su sepultura. La transformación de Policena en estatua, con semblante doloroso, simboliza el dolor eterno y a la vez el amor eterno que le ha prometido Aquiles. En el texto medieval la estatua ocupa el lugar de Policena y se omite así el sacrificio de ésta presente en las obras clásicas:

\author{
Une image d'or tresgiterent, \\ E sachez bien molt s'en penerent, \\ Qu'a Polixena fust senblant: \\ Ne fu ne meindre ne plus grant. \\ Triste la firent e plorose \\ E par senblant molt dolorose \\ Por Achillés qui morz esteit, \\ Qui a femme la requereit. \\ Formee l'unt en tiel maniere \\ Que molt en fet dolente chiere.
}

(V.22435-22444)

Relegada al silencio, Policena refleja totalmente el papel de la mujer en la Edad Media. Sus apariciones al inicio y al final dejan todo el peso de la trama amorosa en manos de Aquiles, guerrero y amante, y primer gran caballero en sucumbir a manos del amor. Al igual que su amado, Policena corre el mismo destino, la muerte, a manos de los griegos que ven en ella la causante de la muerte y la transformación de Aquiles. El autor medieval, al suprimir el sacrificio de Policena en la tumba de Aquiles, sustituyéndolo por lo eterno e inmortal de la estatua, modifica la versión clásica que resulta más cruel para la mentalidad cristiana de la Edad Media. Solamente aparece una Policena aterrada ante su final "Li cuers li mue e change e faut" (v. 26474): 
Com pesme mort e com haïe!

El ne l'aveit mie deservie:

Ço peise li, el n'en puet mais,

Quant Paris ocist Achillés:

Onques n'en fu a li parlé,

Ainz ne fu tot par le suen gré.

A la mort vet que l'om la meine.

(V. 26464-26471)

Esta es la última aparición de Policena que no entiende su muerte: sus declaraciones no son sino una justificación de su comportamiento y una defensa ante la acusación de los griegos. Ésta acepta su destino y prefiere morir antes de no cumplir su función como mujer. También las lágrimas de amor de Policena pertenecen a otro de los estados comunes de los enamorados, son las de una mujer inocente que muere por amor:

Ja ne verreie mais nule jor

Chose que me reconfortast

Ne que leece me donast.

N'istra de mei fille ne fiz

A estre vils e en eissill.

Sui trop de haut lignage nee;

Ne refus pas ma destinee:

O ma virginité morrai.

Biau m'est, quant jo ne maumetrai

La hautece de ma valor.

(V. 26504-26513)

La trama amorosa termina pues trágicamente con la muerte cruel de los amantes. Los dos mueren por amor, pero el discurso pronunciado por la amada de Aquiles justo 
antes de su muerte, deja patente la injusticia de su muerte y lo inocente de su conducta hacia éste:

Seignors, fet ele, vil concire

Avés tenu de mei ocire.

Ainc ne fu mes venjance prise

Que en si grant mal fust reprise;

Trop estes home et riche rei

A faire tel chose de mei.

N'ai mort ne peine deservie,

$\mathrm{Ne}$ ainc ne fis jor de ma vie

Par quei jo fusse ensi traitiee.

(V. 26475-26483)

En cada una de las tramas amorosas estudiadas en Troie, está la huella de Ovidio, en el amor como enfermedad con sus síntomas visibles en el exterior de los amantes, y cuyo final es la muerte, una muerte por amor que se desarrolla completamente en las dos novelas estudiadas, dejando patentes a la vez los códigos para el tratamiento literario del amor en la Edad Media.

Troie crea y reforma las tramas amorosas de sus fuentes latinas para ofrecer una nueva visión adaptada a la época, pero sin alterar la historia legada por los autores clásicos. Eco del cantar de gesta, por la gran extensión dedicada a los episodios bélicos, Troie no deja por ello de proporcionar al género novelesco una nueva imagen de la mujer enamorada y del caballero enamorado, especialmente en la figura de Aquiles, representación del amor sin barreras que poblará el género novelesco. 


\section{APÉNDICE}

A título ilustrativo, y para completar el estudio de la trama amorosa de Jasón y Medea, he seleccionado fragmentos de obras clásicas solamente mencionadas en el apartado dedicado a dicha trama y que, a mi parecer, merecen ocupar estas pocas páginas por su valor documental y como testimonio del amplio tratamiento de esta trama en la época clásica para contrastar con los cambios realizados en la obra medieval, que han sido expuestos en el apartado correspondiente. Para ello, hemos recurrido a los textos fuentes de Eurípides, Apolonio de Rodas y Hesíodo.

\section{-Eurípides, Medea $_{75}$}

En esta obra se relata un episodio totalmente omitido por Benoît de SainteMaure, el asesinato de los hijos de Medea por ella misma.

\section{Nodriza}

“-¡Ojalá que la nave de Argos no volase a la Cólquida y a las cerúleas Simplégades y que nunca cayese en la tierra del pino cortado en las selvas del Pelión, ni la hubiesen armado de remos los héroes muy ilustres que fueron a conquistar el vellocino de oro de Pelias!. No hubiera navegado mi dueña Medea, hacia las torres de la tierra de Yolcos, enamorada de Jasón, ni las hijas de Pelias habrían dado muerte a su padre, ni habitaría en Corintio con su esposo y sus hijos, muy querida de estos ciudadanos, a cuyo país vino fugitiva, y complaciendo sin tasa Jasón; que el lazo más fuerte del matrimonio es la completa sumisión de la esposa al esposo. Pero hoy todo le resulta hostil, e indecibles sus sufrimientos. Jasón faltando traidoramente a sus propios hijos y a mi dueña, contrae regia nupcias con la hija de Creonte, rey de Corintio. La desdichada Medea, herida ignominiosamente en la fibra más sensible de su corazón, clama y jura, invoca la fidelidad que Jasón prometió al darle su diestra, y pone a los dioses por testigos de su ingratitud. Yace sin tomar alimento, presa de intolerables dolores, y siempre deshecha en lágrimas, desde que supo la noticia de la injuria que su esposo le hacía; ni levanta sus ojos, ni los separa de la tierra, sino que, impasible como una piedra, o como las olas del mar oye los consejos de sus amigos, a no ser cuando inclina su muy blanco cuello, y llora a su padre amado, a su patria y sus palacios, abandonados por acompañar a su 
esposo, que ahora la desprecia.

(...) Odia a sus hijos, y no se alegra al verlos. Y temo que maquine algo funesto, que es de carácter vehemente y no puede sufrir injurias. Yo, que lo sé, me estremezco al pensar que acaso atraviese sus entrañas con filado acero, o que mate a la hija del rey y al que se casó con ella, y le sobrevengan después mayores desdichas."

Medea

“-He resuelto ¡oh amigas!, matar cuanto antes a mis hijos y huir de esta tierra, no perderé el tiempo encomendando su muerte a manos más enemigas; sin remedio deben morir, y como es preciso, yo que los procreé, los mataré también. Ea, pues, ármate de valor. ¿Por qué titubeo en perpetrar males crueles, pero necesarios? Anda, mísera mano mía, empuña, empuña el acero, huella la triste meta de la vida, y no seas cobarde ni te acuerdes de tus hijos, a quien tanto amas porque los diste a luz; olvídate en este breve día de que los tienes y llora después, que aunque los mates, siempre te fueron caros y siempre fuiste una mujer infeliz.(...)"

Jasón

“-¡Oh, rabia! Mujer odiosa, mujer la más detestada de los dioses, de mí y de toda la especie humana linaje que has osado hundir el puñal en el corazón de tus propios hijos, en los mismos que diste a luz, y me dejas huérfano, y ves la tierra y el sol a pesar de tu impiedad maldita!¡Ojalá que mueras! Ahora te conozco, no cuando de un palacio y de un país bárbaro te traje a la Grecia, a ti, que eres el más terrible azote, y has hecho traición a tu padre y a la tierra que te crió. (....)"

Medea

“-Largamente replicaría a cuanto acabas de decir si el padre Zeus no conociera los beneficios que de mí has recibido, y tu negra ingratitud. El destino no podía permitir que, despreciándome, tú y tu real cónyuge vivierais felices, insultándome ambos, ni tampoco que Creonte, que te dio la mano de su hija, me desterrara de aquí impune. Si te agrada, llámame, pues leona o Scila, que habita en la costa tirrena, pues te he herido en el corazón como merecías." 


\section{Apolonio de Rodas ${ }_{76}$, Argonáuticas}

En las Argonáuticas, se nos describen los retos que tuvo que superar Jasón para conseguir el vellocino de oro que sí están presentes en la novela medieval.

"Por tal oráculo había escuchado Pelias: que en el futuro un cruel destino le aguardaba, ser abatido por las intrigas de aquel hombre de su pueblo al que viera con una sola sandalia. Y no mucho después, conforme a tu profecía, Jasón, al atravesar a pie el curso del torrencial Anauro, salvó una del lodo, más perdió allí en el fondo la otra sandalia, retenida en la corriente. Y se presentó a continuación ante Pelias, para asistir al banquete que ofrecía en honor de su padre Poseidón y de los demás dioses, más de Hera Pelásgide no se cuidaba. Al verlo se percató al instante y para él dispuso la prueba de una atribulada navegación, a fin de que en el mar o entre gentes extrañas perdiera el regreso.

En cuanto a la nave los cantores de antaño ya celebran que Argos la construyó bajo instrucciones de Atenea. Ahora yo quisiera contar la estirpe y el nombre de los héroes, las rutas del prolongado mar y cuanto realizaron en su errante marcha. ¡Que las musas sean inspiradoras de mi canto!"

\section{$(\ldots)$}

“-Extranjero, ¿por qué relatar cada cosa en extenso? Pues si verdaderamente sois de la extirpe de los dioses, o incluso si, de otro modo, vinisteis por lo ajeno sin ser inferiores a mí, te daré el dorado vellón para que te lo lleves, si quieres, tras ponerte a prueba.

Pues por los hombres valerosos no siento recelo, como vosotros contáis de ese soberano de la Hélade. La prueba de tu fuerza y tu valor será un trabajo que yo mismo llevo a cabo con mis manos, por funesto que sea. En la llanura de Ares pacen dos toros míos de broncíneas patas, que por su boca exhalan fuego. Tras uncirlos al yugo los guío por la dura campiña de Ares, de cuatro fanegas, que rápidamente labro hasta el lindero con el arado y no siembro en los surcos la semilla con el grano de Deo, sino los dientes de un terrible dragón que al crecer se transfiguran en hombres armados. Allí mismo los destruyo y siego bajo mi lanza conforme vienen a mi encuentro por alrededor. De 
mañana unzo los bueyes y a la hora del crepúsculo finalizo la cosecha. Tú, si realizas esto así, entonces en el mismo día te llevaras el vellocino a casa de tu rey. Antes no te lo daría, ni lo esperes. Pues sin duda es indigno que un hombre nacido noble ceda ante un hombre inferior".

“-¡Infeliz!, no espero, ni aunque él sucumbiera, librarme de mis penas. Entonces sería él mi desgracia, cuando perdiera la vida. ¡Maldito pudor! ¡Maldita gloria! Que él, salvado por mi voluntad, indemne, se marche allá donde a su ánimo le plazca. Y en el mismo día, cuando haya cumplido la prueba, muera yo, o colgando mi cuello de una viga, o bien tomando pócimas que destruyen la vida. Pero incluso muerta se mofarán de mí después con burlas. La ciudad entera muy lejos pregonará mi destino; y llevándome de boca en boca por todas partes las mujeres cólquides murmurarán cosas indignas: "la que murió por cuidarse tanto de un hombre extranjero; la que deshonró su casa y a sus padres por ceder a una impúdica pasión. ¿Qué deshonra no habrá para mí? ¡Ay, qué desgracia la mía! En verdad mucho mejor sería dejar la vida esta misma noche en mi alcoba, con un destino insospechado, y escapar a todos los viles oprobios, antes de cometer esos actos ignominiosos e innombrables".

"Advierte ahora cómo yo te prestaré ayuda. Cuando ya vayas a su encuentro y mi padre te entregue los funestos dientes de las quijadas del dragón para sembrarlos, entonces, aguardando a la media noche en su justa mitad y tras bañarte en las corrientes de un río inagotable, tú solo lejos de los demás, envuelto en un manto negro, excava un foso circular. (...)"

"Ciertamente creo que jamás ni de noche ni de día me olvidaré de ti, si escapo a la muerte, si de verdad llego a escapar indemne hasta Acaya y Eetes no nos impone alguna prueba peor. Y si te agrada saber de nuestra patria, te la diré; pues bien a mí mismo el ánimo me incita vivamente a ello. (...)"

"Infeliz, deja de errar las inútiles tempestades, así como el ave mensajera, puesto que hablas de cosas vanas. Si llegas a aquellos lugares y a la tierra de la Hélade, serás honrada y respetada por mujeres y hombres. Ellos te venerarán absolutamente igual que a una diosa, porque a unos hijos les llegaron de regreso a sus casas por tu voluntad, en tanto que a otros sus hermanos, parientes y lozanos esposos se les salvaron de una desgracia completa. Compartirás nuestro lecho en una alcoba legítima. Y nada nos apartará de nuestro amor, hasta que la muerte predestinada nos envuelva”. 
"-Ahora tú misma, diosa, canta el sufrimiento y las intenciones de la joven de Cólquide, ¡Oh Musa hija de Zeus! Pues a mí de verdad el espíritu se me revuelve por dentro en un mudo estupor, cuando pienso si debo llamar fatal aturdimiento de la pasión o fuga vergonzosa, el modo en que abandonó las gentes de los colcos.

Y entre los hombres más nobles de su pueblo, toda la noche, Eetes planeaba un engaño insalvable contra ellos en su palacio, irritado violentamente en su ánimo por la odiosa prueba; y sospechaba que esto no sucedía del todo al margen de sus hijas.

"Infeliz, que el propio Zeus Olímpico sea testigo del juramento y Hera Conyugal, esposa de Zeus: de veras te instalaré en mi morada como legítima esposa, cuando lleguemos de regreso a la tierra de la Hélade".

$(\ldots)$

Así dijo atormentada en su pesada cólera. Ella deseaba incendiar la nave y destruirlo todo absolutamente y arrojarse ella misma en el fuego abrasador. Más Jasón, temeroso, le habló así con melifluas palabras:

“¡Contente infeliz! Tampoco a mí me agrada esto, pero buscamos alguna dilación del combate, tan grande es la nube de enemigos que en derredor flamea por tu causa. Pues todos cuantos pueblan esta tierra desean ayudar a Apsirto, para que te lleven, cual si fueras cautiva, de vuelta a casa junto a tu padre. Nosotros incluso pereceríamos todos con horrible muerte, si trabáramos nuestras manos en la pelea.

\section{Hesíodo $_{77}$, Teogonía}

Este fragmento de la Teogonía nos expone el origen mítico de Medea que está totalmente ausente en la novela medieval.

“Con el incansable Helios, la ilustre Oceánide Perseis tuvo a Circe y al rey Eetes. Eetes, hijo de Helios que ilumina a los mortales, se casó con una hija del Oceáno, río perfecto, por decisión de los dioses, con Idía de hermosas mejillas. Ésta parió a Medea de bellos tobillos sometida a su abrazo por mediación de la dorada Afrodita."(V. 956-962)

77. Hesiodo, Obras y fragmentos. Teogonía. Trabajos y días. Escudo. Fragmentos certamen. trad. y notas de Aurelio Pérez Jiménez y Alfonso Martínez Díez, Madrid, Gredos, 1983, p. 111 


\title{
1.2. EL AMOR EN EL ROMAN D'ENÉAS: ANÁLISIS DE ELEMENTOS MITOLÓGICOS PRESENTES EN LAS TRAMAS AMOROSAS
}

\subsubsection{DICOTOMÍA FEMENINA}

A modo de introducción, en el estudio de las tramas amorosas en Enéas vamos a detenernos en los dos personajes femeninos principales que representan dos actitudes muy diferenciadas, pudiendo incluirse en la clasificación, según la estructura funcional que organizaba a una sociedad tripartita: oratores, bellatores y laboratores propuesta por Georges Duby 78 .

Así, y siguiendo este modelo, en el Roman d'Enéas aparecen dos mujeres que van a desarrollar papeles relevantes y significativos dentro de las tramas amorosas de la novela. Dido, y Lavinia. Ambas representan a dos tipos de mujer, bien diferenciados: Dido es la reina, una mujer viuda que dirige ella sola la ciudad que fundó, Cartago; en cambio, Lavinia representa el ideal de mujer medieval, cuya única función va a ser casarse y dar descendencia a Eneas, encarnando el ideal de madre y esposa de la Edad Media.

En ese orden, el primer personaje femenino principal en aparecer en la novela medieval, y en la trayectoria del héroe, es el de Dido:

\author{
Cartage virent, la cité, \\ dont Dido tint la fermeté. \\ Dame Dido tint le païs; \\ miaus nel tenist quens ne marchis; \\ unc ne fu mais par une feme \\ mielz maintenu enor ne regne.
}

(V. 375-380)

78. Duby, G., Los tres órdenes o lo imaginario del feudalismo, Barcelona, Petrel, 1980, p. 13. 
Dido es pues la reina de Cartago, viuda de Sychée asesinado por su hermano para obtener su reino. La primera característica que nos presenta el autor es la de una mujer poderosa que posee un reino y lo gobierna. Dido pertenece a priori a la primera función como Juno, diosa que representa el poder supremo, y como ella será derrotada, en este caso por el hijo de Venus, quien se erigió ganadora en el Juicio de Paris:

$$
\begin{gathered}
\text { Que que Paris an ait doté, } \\
\text { la pome d'or dona Venus } \\
\text { et juja qu'ele valoit plus } \\
\text { que les dous autres de bialté. }
\end{gathered}
$$

La novela desde el principio, al relatar el juicio de Paris de manera exhaustiva, parece dar prioridad a la tercera función, aunque en la sociedad medieval no ocupe el primer lugar. Nuestro estudio de las tramas amorosas en Enéas evidencia el papel emergente del Amor en la novela de esta época.

Dido es la viuda sin descendencia que, al igual que Eneas, tuvo que huir de su país para fundar una nueva ciudad. Resulta que ambos tienen varios episodios de su vida en común (huida de su patria, fundación de un reino...). Buena reina, consigue fundar su ciudad gracias a su astucia e ingenio:

$$
\begin{gathered}
\text { c' une cité i a asise; } \\
\text { puis conquist tant par sa richece, } \\
\text { par son angin, par sa proëce, } \\
\text { que ele avoit tot le païs } \\
\text { et les barons a soi sozmis. }
\end{gathered}
$$$$
\text { (V. 402-406) }
$$

Dido, en su primera etapa, encarna las cualidades que ha de tener un buen rey como representante de la primera función, sin embargo su condición de mujer la llevará 
a un terrible final y provocará que su buen gobierno cambie totalmente a causa de sus debilidades "femeninas".

De este modo se hace evidente en Dido la dualidad: por una parte, tenemos la faceta de Dido reina, que participa de las actividades de los hombres, estando al mando de un país y, por otra parte, tenemos la faceta de la Dido mujer que se enamora y deja de lado su reino. En este sentido aparece también caracterizada Dido como una mujer positiva y negativa. Positiva cuando encarna la primera función y negativa en su segunda etapa, cuando representa la tercera función. Para Huchet: "la primera y la tercera función son incompatibles en la mujer y por eso su final va a ser desgraciado 79 ".

En su segunda etapa Dido encarna las debilidades de las mujeres: incapaz de cumplir la palabra que dió a su marido, se une a Eneas y descuida la protección de su reino así como sus funciones y obligaciones como reina. En definitiva, deja de poseer las cualidades de un buen rey para actuar como una mujer, desapareciendo así la faceta positiva que poseía en su primera etapa:

\title{
(...) molt soloit bien terre tenir et bien soloit guerre baillir, or a tot mis an nonchaloir
}

et an obli par non savoir.

\author{
Amors li a fait oblier \\ terre a tenir et a garder. \\ Si enemi gastent sa terre, \\ el ne prise plus pais que guerre $(. .$.
}

(V. 1408-1416)

Queda patente en estos versos el cambio de actitud de la reina, con la utilización del pretérito indicando las acciones pasadas de Dido y el adverbio "or" que subraya su comportamiento actual. Además el adverbio "bien” reiterado en la primera parte 
contrasta con los verbos: soloit baillir, fait oblïer, gastent, que ponen de manifiesto el mal comportamiento de la reina en su segunda etapa.

Debido a un papel "equivocado", Dido no puede sino encarnar todos los aspectos negativos de la mujer medieval, en su segunda etapa, al haberse dejado llevar por la pasión, despojándose de las características que la acercaban a los hombres. Es más, no sólo traiciona el amor prometido a su marido y descuida las labores de reina sino que no tiene descendencia. Asistimos pues a una subversión de la primera función, demostrada de manera didáctica en el texto medieval. Es que para el siglo XII el papel principal de la reina era garantizar la transmisión de la sangre a un heredero varón cuya existencia era considerada esencial para la sucesión pacífica en el poder ${ }_{80}$. Esta carencia en Dido será el motivo principal de sus lamentos antes de morir:

\author{
(...) Se j'aüsse de vos anfant, \\ qui vos sanblast ne tant ne quant, \\ que peüsse por vos baisier \\ et acoler et anbracier \\ et qui de vos me confortast, \\ ce m'est avis que mielz m'alast (...).
}

(V. 1739-1744)

La ausencia de descendiente varón no sólo deja sin heredero al reino de Cartago tras la muerte de Dido sino que también confirma la idea que el autor nos transmite a lo largo de la trama amorosa de Eneas y Dido, la de un amor estéril e ilegítimo. Para que un matrimonio pudiera ser legítimo en la Edad Media tenía que haber descendencia que sellara la unión entre los dos cónyuges. Además de no haber descendientes, Dido no tiene padre que la entregue, como en el caso de Lavinia. Tras su huida, Dido no está bajo la protección de ningún hombre: es ella misma la que tiene que procurar su protección, de ahí el paralelismo con la representación de Cartago como ciudad infranqueable aunque inconclusa.

80. Wade Labarge, M., La mujer en la Edad Media, Madrid, Nerea, 2003, p. 71. 
Las funciones que organizan la sociedad medieval se reflejan igualmente jerarquizadas en la descripción de Dido: en primer lugar, la función de reina y después la función de mujer. Sin embargo, cuando está en su fin, deja de lado la tercera función que había predominado en ella durante su segunda etapa, para volver a la primera función. Dido comienza y termina siendo ante todo reina y ostentando el poder. Sus últimas palabras dejan constancia de su preocupación de dejar a Cartago sin descendiente que pueda gobernar:

$$
\begin{aligned}
& \text { (...) ci lais m'enor et mon barnage, } \\
& \text { et deguerpis sanz oir Cartage, } \\
& \text { ci perc mon nom, tote ma glore, } \\
& \text { mais ne morrai si sanz memore } \\
& \text { qu'en ne parolt de moi toz tens, } \\
& \text { vials non antre le Troïens. }
\end{aligned}
$$$$
\text { (V. 2051-2056) }
$$

Dido pierde así la fama de buena reina y, en su lugar, será recordada por la relación que mantuvo con Eneas y la llevó al suicidio.

Por otra parte, hay que precisar que tampoco la tercera función está presente en Dido de forma legítima, ya que es Venus quien, a través de Ascanio, transmite el amor como indicio de la tercera función, de la que la reina será víctima. Por el contrario, Dido sin ayuda de nadie pudo poseer el mando y ejercer la primera función, sin que nadie la guiara para conseguir su reino.

En la literatura épica anterior, la reina es la única mujer mencionada y considerada como exponente de ciertos valores: tenía que ser casta, prudente, discreta. Su castidad debería ser tomada como ejemplo por las demás, ya que estaba por encima de ellas. No debía participar en las batallas y usurpar el papel destinado a los hombres. La reina no sólo constituía el vértice en la pirámide de la estructura social femenina sino que, además de las responsabilidades familiares, se le sumaban las responsabilidades en beneficio de lo que constituía su reino. 
Ahora bien, las facetas negativas de la mujer no solo están expuestas en el propio personaje de Dido sino que, por asociación, el autor las extiende a través de numerosas sentencias acerca del mal comportamiento de las mujeres:

$$
\begin{aligned}
& \text { (...) molt par est fous qui feme croit: } \\
& \text { ne se tient prou an sa parolle; } \\
& \text { tel tient l'en sage qui est fole. }
\end{aligned}
$$

(V. 1590-1592)

Queda en estas afirmaciones constancia de la opinión del autor sobre las mujeres y sus actuaciones, reveladora de cierta misoginia que nos recuerda a la de Benoît de Sainte-Maure. Dido ocupa el rango más elevado que una mujer en la Edad Media podía ocupar, el de reina, sin embargo su condición de mujer hace que sea infravalorada por el autor de la obra. El comportamiento de Eneas, similar al de la reina, no es, ni mucho menos, tan severamente juzgado por parte del autor. Es que Dido va a ser la primera que manifieste su amor hacia Eneas, la primera que rompa la promesa hacia su marido y, de algún modo, someta la primera función a la segunda y a la tercera.

Como contraste, la protagonista de la segunda trama amorosa, Lavinia, que encarna los valores positivos del sexo femenino, en tanto que llegará a ser esposa y futura madre de una larga descendencia. De antemano, Lavinia se comporta como una buena hija aceptando a Turno como esposo y después a Eneas. Lavinia es un personaje imprescindible ya que va a ser quien transmita el linaje de Eneas y el personaje que destaca por su comportamiento casto y prudente. Sugerida desde el principio de la novela medieval, Lavinia no toma cuerpo hasta que es mencionada en los Infiernos por el padre de Eneas, y su importancia narrativa no se desarrollará hasta la conversación con su madre.

Pero el rasgo negativo ancestral aparece en Lavinia, como motivo de la guerra entre Turno y Eneas que provocará numerosos daños en su reino. La mujer como causa de guerra ya está presente en la figura de Helena que provocó la destrucción de Troya, como consecuencia del juicio de Paris. Continúa aquí la tradición misógina de los autores medievales: 
Por asez po de començaille

sort l'acheisons de la bataille,

et par molt petite avanture

mut la guerre, qui tant fu dure

dont mil home furent ocis.

(V. 3519-3523)

A pesar de que Helena y Lavinia no tienen sino indirectamente la culpa de la guerra, el autor las presenta como causantes directas de la destrucción y de la guerra en sus respectivos reinos. Sin embargo, si cae en ellas el peso mítico de la culpa, son las acciones de los personajes masculinos las que directamente desencadenan la guerra: Paris, al elegir a una mujer casada, y Eneas, al escoger a una mujer que ya está comprometida con Turno, tal y como lo afirma éste último:

"Si n es vers moi par seirement: de ta terre m'as erité, o ta fille m'as tot doné ; ge l'ai plevie et afiee ; ne l'ai ancor pas esposee, $(\ldots)$ et les chastiaus ai recoilliz, g'en ai les tors et les donjons et les homages des barons $(\ldots) . »$

(V. 3848-3857)

Es que Turno ya posee la tierra y los vasallos le rinden homenaje, pero no posee todavía a Lavinia ya que no se ha casado aún con ella, cuando se puede decir que Eneas posee ya a Lavinia, ya que ella está enamorada de él; sólo le queda pues luchar contra Turno para poseer también la tierra.

La mujer se considera trofeo de guerra, tanto Helena como Lavinia que serán respectivamente recompensas de Paris y de Eneas. Ambas aceptan su destino sin 
oponerse: Helena se va con Paris abandonando a su marido y Lavinia acepta el compromiso con Eneas, pactado por su padre.

Lavinia, como mujer, tiene que estar bajo la tutela de un hombre, función desempeñada primero por su padre y después por Eneas. Aparecen en la novela numerosas citas apoyando la idea de la sumisión de la mujer a un hombre, su dependencia y sus funciones. Como ya hemos dicho, el matrimonio, según Duby, es un contrato por el cual la mujer queda sometida a otro hombre. El vocabulario empleado hace del contrato matrimonial el homólogo del contrato entre el vasallo y el señor. Como éste, une a dos seres iguales en naturaleza pero necesariamente desiguales en poder, uno de los cuales debe servir al otro. La mujer está situada en el plano inferior de la jerarquía social, siendo a la vez vasalla del hombre y vasalla de Dios 81 . En la Edad Media, los padres estaban convencidos de que no sólo tenían el derecho sino también el deber de acordar los matrimonios de sus hijos. Esta idea también se ve reflejada en la novela, cuando Lavinia es prometida primero a Turno y luego a Eneas sin que se tenga en cuenta su opinión. En este caso la primera unión con Turno no es legítima porque se contó con la colaboración de la madre de Lavinia; así lo expone el propio rey Latinus, padre de Lavinia:

\author{
(...) Ge l'ai promise estre mon gré \\ et ancontre ma volanté \\ a un prince de cest païs ; \\ Turnus a a non li marchis ; \\ ma moillier vielt qu'il ait mon regne \\ et Lavine ma fille a fegne, (...)
}

(V. 3233-3238)

El amor que surge en Lavinia hacia Eneas hará que la situación de ésta cambie: desde un matrimonio pactado por su padre y por el destino ordenado por los dioses, 
hasta un matrimonio deseado por ella. Pues, será ella quien tome la iniciativa tras descubrir lo que siente por Eneas a través del famoso diálogo con su madre, que desemboca en una declaración de amor indirecta por parte de Lavinia al pronunciar el nombre deletreado de su amado:

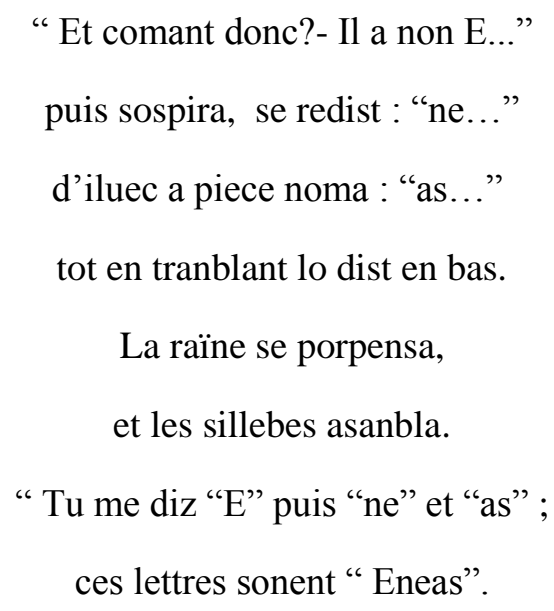

(V. 8552-8560)

En efecto, vemos cómo en las escenas amorosas el héroe va a estar relegado a un segundo plano dejando toda la importancia narrativa a la mujer. En ambas tramas amorosas son las mujeres, Lavinia y Dido, quienes siguen el rumbo de sus sentimientos y actúan, mientras que para los hombres, al quedarse relegada a un segundo plano la tercera función, es la primera función la que predomina. Así Eneas es, por encima de todo, el protagonista de una lucha por una tierra, por fundar un nuevo reino y crear una nueva Troya, cumpliendo con las fases obligadas de su trayectoria heroica.

\subsubsection{DIDO Y ENEAS}

Este primer episodio, el de los amores de Dido y Eneas, ocupa varios libros en la Eneida con una extensión aproximada de unos 3000 versos (empieza en el libro I y finaliza en el libro IV) mientras que en el Roman d'Enéas la extensión es menor, en torno a unos 1700 versos aproximadamente, concentrada en la primera parte de la novela. En la obra medieval este episodio coincide con el primer desembarco de Eneas 
tras su travesía de siete años sufriendo la ira de Juno, cuando, en la Eneida, se sitúa en su cuarta parada, después de desembarcar en Tracia, Delos, Creta y las islas Estrófades.

Desde el punto de vista de la estructura interna, podemos ver una ruptura con la literatura épica anterior. La trama amorosa comienza con una presentación histórica de la que va a ser el personaje principal: Dido.

\author{
D'icel païs n'ert mie nee, \\ ainz ert de Tire la contree ; \\ Sicheüs ot a non ses sire,
}

(V. 381-383.)

Así, el autor nos da su origen y su situación: viuda y extranjera, Dido comparte con Eneas el haber sido expulsada de su reino y el deber de fundar uno nuevo. Además de contarnos su pasado y su estatus social, el autor marca ya desde el principio el carácter negativo de este episodio, al ser Dido una mujer viuda sin descendencia y reina de Cartago.

Por otra parte, y apoyando la idea de la negatividad presente ya desde el principio, Cartago es la ciudad elegida por Juno, también diosa protectora del matrimonio, pero que persigue a los troyanos desde la ofensa de Paris. Su presencia en Cartago viene significada por el templo que Dido mandó edificar para honrarla como protectora de su ciudad:

Un tenple fist anprés Dido,
ou costivee estoit Juno;
molt estoit riche a desmesure ;

(V. 515-517)

La negatividad que pesa sobre la unión de Dido y Eneas se refleja también en el conocimiento por parte de Dido de la imposibilidad de Eneas de quedarse en esa tierra, 
pues ella sabe que Eneas debe seguir su destino. Si la etapa de Cartago es negativa para Dido, lo es sobre todo para Eneas que deja de lado su cometido:

\author{
De la celestial ligniee \\ ot an Troie un riche baron; \\ de cele grant ocision \\ qu'i feisoient la nuit li Greu, \\ lo garantirent bien li deu ; \\ fors lo mistrent de la cité ; \\ grant gent ot o lui asanblé.
}

(V. 572-577.)

En muchos rasgos,-el encuentro, la atracción mutua, el hecho de ser viudos y extranjeros ambos-, el episodio de los amores de Dido y Eneas se asemeja mucho a la fuente latina; salvo ciertos anacronismos y amplificaciones a través de las descripciones, el episodio es prácticamente igual. Sin embargo, llaman la atención dos cambios que opera el autor medieval. El primero es cómo Dido llega a enamorarse de Eneas: en el Roman d'Enéas es Ascanio a través de Venus quien tiene el poder de enamorar, cuando en la Eneida es el propio Cupido quien se hace pasar por Ascanio y provoca el enamoramiento de Dido. Elimina así el autor medieval al dios del amor: Cupido. Veamos los dos pasajes significativos en este sentido:

\title{
-Eneida, Libro I, V. 716-721
}

“Con los ojos, con todo el corazón ella le va estrechando contra sí y a ratos le acaricia en su regazo sin saber, pobre Dido, qué poder tiene el dios que acoge por su mal. Pero él se acuerda de su madre, la diosa de Acidalia, y comienza por borrar poco a poco la imagen de Siqueo, y porfía en asaltar con llama de amor vivo el alma largo tiempo sosegada y el corazón que había ya perdido la costumbre de amar." 
-Enéas, V. 769-780

\author{
Ele ot d'amor la poësté; \\ quant vit que son fil ot mandé, \\ soëf antre ses braz lo prent, \\ molt lo baisa estroitement ; \\ an cel baisier li a doné \\ de faire amer grant poëste : \\ qui anprés li lo baisera \\ del feu d'amor espris sera. \\ A cels quil meinent dist Venus \\ qu'ons ne fame nel baisast plus, \\ fors la raïne et Eneas. \\ Il s'an tornent eneslopas.
}

La segunda diferencia se produce al final del episodio, en el desenlace: en la Eneida, Dido maldice y clama venganza contra Eneas, asociándose así a Juno en su odio a los troyanos que han causado la destrucción de su reino y su muerte:

\title{
-Eneida, Libro IV, V. 620-624
}

"Esto es lo que os pido, la última ansia que escapa de mi pecho con mi sangre. Y vosotros, mis tirios, perseguid sañudos a su estirpe, y a toda su raza venidera, rendid este presente a mis cenizas: que no exista amistad ni alianza entre ambos pueblos.”

En cambio, en el Roman d'Enéas, Dido perdona a su amado antes de morir. Quizás este cambio que opera el autor medieval sea debido a la moral cristiana o a la 
intención literaria de acentuar el grado del amor de Dido. Culpable, y loca de amor, la Dido medieval permite que el amor paralice la acción política de Cartago, descuidando sus obligaciones. El amor venusiano es considerado así como una maldición, o más exactamente como una enfermedad que desencadena la muerte ${ }_{82}$ :

\author{
Molt fui ancois et pros et sage, \\ que me donast amor tel rage, \\ et molt fusse buene eüree, \\ se ne venist an ma contree \\ li Troïens qui m'a traïe, \\ par cui amor ge perc la vie. \\ Il m'a ocise a molt grant tort ; \\ ge li pardoins ici ma mort ; \\ par nom d'accordement, de pais, \\ ses garnemenz an son lit bais.
}

Gel vos pardoins, sire Eneas.

(V. 2057-2067)

Volvemos a encontrarnos con la descripción tradicional del amor con todos los síntomas de una enfermedad, tal y como lo indica E. Faral 83 , recordando a Ovidio quien califica a los enamorados como enfermos "aeger", "languidus". Así, aliviar a los enamorados de su pasión es curarlos de su enfermedad. En este caso, la enfermedad acaba con el suicidio de la reina, acto totalmente condenado por la sociedad medieval, pero que en la obra no está tan castigado, debido no sólo a la generosidad de la reina con Eneas sino también por el perdón de su esposo en los Infiernos; de tal manera que, allí, y según Huchet, Dido recupera su función legítima de mujer, así como la

82. Poirion, D., “De l'Énéide à l'Enéas, mythologie et moralisation”, in Cahiers de Civilisation médiévale, XIX, Poitiers, 1976, p. 213 ss.

83. Faral, E., Recherches sur les sources latines des contes et romans courtois du moyen âge, Paris, Slatkine Reprints, 1983 , p.133. ss. 
renovación de la promesa hecha en su matrimonio 84.

$$
\begin{aligned}
& \text { Quant Dido l'ot ensi parler, } \\
& \text { el nel pot onques es garder, } \\
& \text { car molt li estoit enemie; } \\
& \text { enz en un bois s'en est foïe } \\
& \text { ou Sicheüs ses sire estoit, } \\
& \text { qui en s'amor a maior droit. } \\
& \text { Por ce qu'el li avoit mentie } \\
& \text { la foi qu'el li avoit plevie, } \\
& \text { ne s'osoit pas vers lui torner, } \\
& \text { ne l'osot mie esgarder, } \\
& \text { ne pres de lui ne s'aprismot: } \\
& \text { por son forfet se vergondot. }
\end{aligned}
$$$$
\text { (V. 2651-2661.) }
$$

En la Eneida, este encuentro con Dido en los Infiernos se asemeja mucho al encuentro que reproduce el autor medieval en su obra, aunque los sentimientos de culpa de Eneas están más exteriorizados y más explícitos:

"Ella le vuelve el rostro y mantiene los ojos clavados en el suelo y no le mueve más toda su plática que a un duro pedernal o al mismo mármol de marpesia roca. Se aparta brusca al fin y se va huyendo hostil de su presencia y se acoge a la umbría en que Siqueo, su esposo de otro tiempo, comparte su ternura y con el mismo amor le corresponde. Eneas, no menos apenado de su duro infortunio, la sigue largo trecho con la vista, bañada en llanto y en piedad el alma." (Eneida, Libro IV, V. 317-477).

En el tema de la confesión del amor reside una de las semejanzas con el episodio de Lavinia. Dido, después de darse cuenta de lo que siente por Eneas, se lo confiesa a su 84. Huchet, J.C., Le roman médiéval, Paris, PUF, 1984, p. 119 ss. 
hermana, la cual la apoya en su decisión y será su aliada hasta el final, intentando solucionar la huida de Eneas a través de la "sorcière". De la misma manera, Lavinia también se lo confesará a su madre, aunque ésta no la apoyará sino que luchará para que su hija elija a Turno. En ambas tramas son las mismas protagonistas las que se dan cuenta y declaran lo que sienten hacia Eneas:

"Dame, por coi morez a honte?

Ceste amistié rien ne vos monte, qu'avez anvers vostre seignor : morz est, ja a passé maint jor. A duel ussez vostre jovante, an lui n'a mes negune atante, de lui n'avroiz vos mes anfant ne dolce amor ne bel sanblant, ne garantie ne secors.

$(\mathrm{V} .1327-1335)$

Relevante en este episodio es la belleza del ser amado, como causante del enamoramiento, puesta de relieve por el autor medieval y que no aparece en la Eneida. Tanto las descripciones de Dido como las de Eneas ponen de relieve la belleza de los dos protagonistas que apoya la idea de la idealización del ser amado. Esta idea la expone De Bruyne:“Il va de soi que les auteurs mettent la beauté féminine en rapport avec l'amour sous toutes ses formes. L'amour se définit d'après André Chapelain, en fonction de la perception ou de la représentation de la forme, c'est-à-dire de la beauté 85 ". Por ello, la figura amada aparece bañada de luz y, en el caso de Dido, la luz emana también de su vestimenta:

La raïne se fu vestue

d'une chiere porpre vermoille, 


$$
\begin{aligned}
& \text { bandee d'or a grant mervoille } \\
& \text { trestot lo cors desi as hanches } \\
& \text { et ansemant totes les manches. } \\
& \text { Un chier mantel ot afublé } \\
& \text { menüemant ert d'or goté ; } \\
& \text { a un fil d'or ert galonee, } \\
& \text { et sa teste ot d'orfrois bandee. } \\
& \text { (...) quant vit la dame Tirïene, } \\
& \text { ce li fu vis que fust Dïene : } \\
& \text { molt i ot bele veneresse, } \\
& \text { del tot resenblot bien deesse. }
\end{aligned}
$$

(V. 1466-1488)

En cuanto al sacrificio de Dido, no habrá sido totalmente en vano, ya que éste forma parte del destino de Eneas, junto con el amor y la muerte de su primera esposa Creusa. Según Poirion: "los amores de Dido y Eneas son sustanciales de la prueba iniciática del héroe 86 ”. Es más, la rendición de Dido deja en un primer plano al protagonista frente a su destino.

Después de ver los sub-episodios más destacados en los que se divide el episodio de amor entre Eneas y Dido en el Roman d'Enéas, conviene aludir al mismo episodio dentro de la Eneida que, siendo el hipotexto del Roman d'Enéas, también ha sufrido numerosos cambios frente a la historia tradicional, por innovaciones operadas por Virgilio. La principal divergencia de Virgilio con respecto al itinerario más habitual radica precisamente en el episodio de Dido y en la escala cartaginesa de Eneas después de la tempestad y el naufragio.

Virgilio, en lo referente a Dido y Eneas, imitó de manera puntual los amores de Jasón y Medea. Esta fuente nos dice que, a diferencia de lo que nos presenta Virgilio, Dido se mantuvo fiel y casta a la memoria de su marido y se suicidó para no acceder a 
las insistentes demandas de matrimonio por parte del rey de los libios, sin que haya ninguna referencia a Eneas. Esto demuestra que, en lo que se refiere a este episodio, el mismo Virgilio intentó renovar la tradición dando una nueva versión. La tragedia de Dido constituye la parte de la Eneida en la que mejor puede comprobarse el uso que hace Virgilio de la herencia poética. En efecto, en el relato de los sentimientos de la reina Dido subyace también la Ariadna abandonada del poema 64 de Catulo, la Medea y la Fedra de Eurípides, la Circe y la Calipso de la Odisea y hasta la Penélope o la Deyanira de Sófocles87. A pesar de que, como hemos dicho más atrás, los amores entre Dido y Eneas se desarrollan en los libros I al IV, es en este último donde se ve el desenlace final y las consecuencias de su amor. La tradición griega presentaba a Dido como una mujer fiel, sin embargo Virgilio nos presenta a una Dido enamorada de Eneas al que acoge en su reino y, tras el abandono de éste, se da muerte.

Esta comparación confirma la mayor carga mitológica en la Eneida. En el Roman d'Enéas, las referencias a divinidades secundarias e incluso episodios donde aparecen diosas (conversación de Juno y Venus) se han suprimido, alejando así la obra medieval de un culto ajeno a la religión cristiana. En definitiva, lo que es de señalar es que el autor del Roman d'Enéas proporciona una imagen sintética y sobria de las divinidades antiguas, explotando de una manera racional la estructura mítica presente en la Eneida, con fines didácticos a la vez que ideológicos.

\subsubsection{LAVINIA Y ENEAS}

Este segundo episodio se distingue del primero por ser completamente invención del autor del Roman d'Enéas. En la obra clásica, apenas está mencionado el episodio amoroso entre Eneas y Lavinia, siendo su papel claramente secundario.

Lavinia, según la mitología romana era la hija del rey Latinus y de Amata. Estaba prometida a Turno antes de la llegada de Eneas pero fue dada a éste por los designios de los dioses 88 . De su matrimonio con Eneas nació Ascanio según la tradición, 
cuando, en la Eneida, Ascanio se nos presenta como hijo de Eneas y Creusa.

Los episodios que relatan los amores de Dido y de Lavinia poseen ciertos puntos en común: ambas sufren los mismos síntomas, se lo confiesan a sus confidentes. Sin embargo se evidencian ciertas variaciones: la primera diferencia reside en el carácter positivo que presenta la segunda trama, marcada desde el principio, no sólo porque el reino de Lavinia viene anunciado como el elegido por los dioses para que Eneas funde su nuevo reino, sino porque no existe ninguna intervención divina como en el caso de Dido y Eneas. Lavinia nos es presentada como una joven ingenua, que desconoce los síntomas del amor. El diálogo con su madre es el que le da a Lavinia la independencia como personaje principal, que no ostenta en el modelo clásico ${ }_{89}$ :

“- Ge ne m’i sai prou atorner.

-Et tu l'apren.-Dites lo moi, que est amors? Ge ne sai coi.

Ge nel te puis noiant descrire.

Qu'en savrai donc, se ne l'oi dire?

Tes cuers t'aprendra a amer.

Se n'an orrai autre parler?

Tu nel savras ja par parolle.

Toz tens an quit donc estre fole."

(V. 7888-7897.)

Estos versos son muestra de la principal aportación de esta novela que reside en el análisis psicológico de los personajes, hecho por el autor mediante monólogos y diálogos en los que asoma su desarrollo individual.

La segunda diferencia: si en el episodio de Dido hemos podido ver en la propia protagonista los efectos del amor, en el episodio de Lavinia es la madre la que se los enumera, dándole a conocer los estados que provoca, comparados con la enfermedad. 


\author{
Pire est amors que fievre agüe, \\ n'est pas retor, que l'an an süe; \\ d'amor estuet sovant süer \\ et refroidir, fremir, tranbler \\ et prendre tot boivre et mangier (...) \\ et degiter et tressaillir, \\ müer color et espalir, \\ giendre, plaindre, palir, penser \\ et sanglotir, veillier, plorer : \\ ce li estuet fere sovant \\ qui bien aimme et qui s'en sent.
}

(V. 7919-7929)

De este modo, aparecen en este pasaje varios sub-temas relacionados con el amor y que el autor desarrolla de modo explícito, con una función tan didáctica como temática:

-El amor es un mal que nubla a los enamorados:

Fole Lavine, aies mesure,

N'atorner pas a ce ta cure,

Ne te puisses d'amor partir

Des que te voldrar repentir.

(V.8679-8682)

-El amor da fuerza y valor a los enamorados:

car ainz que la bataille soit,

Li voil primes faire savoir, 
s'an ert plus fiers al mien espoir;

Se de m'amor est a seür,

Molt l'an trovera cil plus dur,

Molt an prendra grant hardement,

s'il sot onques d'amor noiant.

(V. 8756-8762)

-Impaciencia de los enamorados por verse ${ }_{90}$ :

\section{Quant peüsse prendre m'amie, \\ donc mis ge terme? Ne fis mie, \\ bien tost me porroit esloignier: \\ il nuist sovant a por loignier \\ chose, quant ele est aprestee, car an po d'ore est tost müee.}

(V. 10053-10058)

En definitiva, tanto Lavinia como Dido sufren las consecuencias del amor y cada una representa una de las dos caras del amor. Humanizando a la protagonista del primer episodio amoroso, el autor medieval la acerca a la mentalidad cristiana, ya que Dido perdona a Eneas. La declaración amorosa de ambas va acompañada de gestos que desvelan su iniciativa y explicitan al lector sus sentimientos.

También hemos visto cómo ambas declaraciones de amor femeninas contrastan

90. Faral, E., op. cit., p.133 ss. 
con el silencio de Eneas que, según la mentalidad medieval, se doit molt bien covrir (V.9078). En el ámbito del amor, los personajes masculinos ceden todo el protagonismo a los personajes femeninos, ocupando un segundo plano, parece ser, más acorde con su sexo, en las intrigas amorosas.

Tampoco las mujeres de Eneas escapan a la fatalidad, tanto en la Eneida como en el Roman d'Enéas: la desgraciada Creusa, separada de su esposo y su hijo, muere a manos de los griegos; la hermosa y desventurada reina Dido, abandonada y enamorada locamente de Eneas decide suicidarse; y la joven y dulce Lavinia, oscurecida por el recuerdo de Helena, traerá la guerra por deseo de los dioses.

Para concluir podemos decir que los episodios analizados reflejan una dualidad intrínseca al relato. Dentro de este reparto temático y con relación a la trayectoria heroica, Dido encarna el amor negativo que acaba con la muerte de la amada, como representación del amor prohibido y adúltero, a través de una perversión del amor en una reina que descuida las obligaciones de su función. En cambio, Lavinia encarna el amor positivo desde el principio, simbolizado en el designio de los dioses, pero personificado en el texto medieval por el amor libre, en definitiva el único que puede triunfar. La representación de estas dos tramas amorosas servirá de modelo para la literatura posterior, desarrollándose en el amor cortés que se revelará muy influenciado por el tratamiento del amor dentro de "la materia antigua". En especial, el personaje de Lavinia, en su tratamiento deliberadamente exhaustivo por el autor medieval, es, en último término, canalizador de la explotación de un nuevo concepto del amor, motor de la acción y de la modificación del personaje femenino. 
II. LA GUERRA EN EL ROMAN D' ENÉAS Y EL ROMAN DE TROIE: ESTUDIO COMPARATIVO DE LAS NOVELAS MEDIEVALES Y SUS MODELOS CLÁSICOS 


\section{INTRODUCCIÓN}

En este apartado de mi trabajo, tras haber analizado las tramas amorosas, me voy a centrar en el estudio de otro tema sustancial en estas novelas: la guerra. Además de examinar la temática guerrera en ambas novelas medievales, realizaré un estudio comparativo al respecto entre los hipertextos y sus modelos: la Eneida en el caso de Enéas y las obras de dos autores: Dictis Cretense y Dares Frigio en el caso de Troie, fuentes ya precisadas anteriormente.

En el seno de la temática guerrera están omnipresentes los caballeros. Empezaré diciendo que la caballería encuentra en la novela otra forma de difusión que en los cantares de gesta, vehículo de su más amplia representación en la Edad Media. Las novelas estudiadas fueron creadas en el siglo XII, siglo en el que la caballería va a implantarse como clase social en la sociedad medieval, y esta nueva organización social es la que va a influir en los cambios realizados en las novelas con respecto a sus modelos clásicos.

Para entender dichos cambios, hay que tener en cuenta, como expone Le Goff, que «toutes les civilisations honorent des personnages humains et/ou surnaturels, à qui elles vont jusqu'à rendre un véritable culte. Ainsi l'Antiquité gréco-romaine a vénéré des héros, des dieux et des êtres intermédiaires, héros divinisés et demi-dieux. La mutation des civilisations entraîne une modification de ces catégories ${ }_{91} »$. Por otra parte hay que destacar que en la época en la que se escriben las novelas se produce un cambio importante en la mentalidad: «l'installation en Occident d'une nouvelle religion, le christianisme, et d'un nouveau système politique et social, la société médiévale, entraîne un changement profond des Dieux et des héros92». Esta idea se desarrolla en las novelas estudiadas, que intentan crear ideales de caballeros partiendo de los héroes clásicos, modificándolos según la mentalidad de la época.

91. Le Goff, J., Héros du Moyen Âge, Le saint et le roi, Editions Gallimard, France, 2004, p. 5.

92. Ibídem. 
En efecto, estas novelas, en mayor o menor medida, nos detallan no sólo los ideales guerreros de un caballero medieval sino también los ideales morales: el caballero manifiesta su condición de hombre y actúa en base a un reglamento guerrero que tiene en la valentía y en la defensa a los más débiles sus principales valores. Al analizar los personajes principales de las novelas, podemos ver reflejados dichos ideales de la caballería que representa « un groupe professionnel unissant ceux que leur richesse rendait aptes au combat. L'adoubement à cette époque est encore très simple. Au XII siècle, le caractère militaire de la chevalerie s'atténue alors que ses aspects moraux se développent, conduisant à une certaine mystique et au formalisme des cérémonies 93 ».

Según varios estudios, Francia es «la terre qui - de l'avis de tous - vit naître et se développer la chevalerie, les études sur cette «institution»apparaissent en grand nombre déjà au XVIII, et plus encore au XIX siècle 94 ». Esto justifica el estudio de los ideales de caballero que son transmitidos a través de textos literarios, que no sólo proporcionan la visión de esta práctica en la época en la que se escriben sino también dan a conocer a los historiadores sus prácticas, dado que la literatura revela la imagen de la sociedad en la que se efectúa.

En un primer momento, y centrándome en el tema de la guerra, compararé Enéas con la Eneida, viendo los cambios que aporta no sólo en los hechos bélicos sino también en la figura de su personaje principal Eneas como ideal de caballero medieval, fijándome para ello en su viaje iniciático. En segundo lugar procederé igualmente con Troie comparándola con sus modelos y viendo las partes creativas del autor medieval y su punto de vista desde el análisis de los personajes principales.

Por otra parte, para estudiar la figura del caballero en ambas novelas, protagonista de batallas, y representante de uno de los grupos sociales fundamentales en la Edad Media, hay que tener en cuenta la gran repercusión de la figura del caballero en la época en la que se escribieron los romans antiques y de ahí, que sirvan como ejemplo de los ideales de caballero. Enéas recoge en su narración un compendio de cánones para ser un buen caballero y en la figura del héroe el representante ideal de la caballería.

93. Flori, J., L'essor de la chevalerie, Genève, Droz, 1986, p. 23.

94. Ibid., p. 9. 
Siguiendo esta idea, es importante recordar la constitución de este grupo social en los siglos XI-XII que, junto a los oratores y los laboratores, conformara la estructura de la sociedad medieval. Tal y como expone Jean Flori, «la chevalerie rêvet en effet des aspects professionnels et sociaux. Société de guerriers d'élite, la chevalerie a bien entendu partie liée avec la guerre, ses méthodes, ses techniques et son éthique ${ }_{95}{ }^{\text {. Esta }}$ idea se concreta plenamente en la literatura medieval de los siglos XI-XII, y justificando la elección del tema del guerrero, como objeto de estudio que, dentro de estas obras, ocupa un lugar determinante y significativo del desarrollo del género novelesco, en cuanto al perfil más individual del personaje masculino.

Antes de comenzar el análisis, he de precisar que el esquema de este apartado se guiará por la cronología de las obras estudiadas. A diferencia del capítulo anterior, este capítulo, comenzará su análisis por el Roman d'Enéas debido a la presentación más manifiesta de la imagen del caballero dentro de la novela. 


\subsection{ENÉAS Y LA ENEIDA: CAMBIOS REALIZADOS CON RESPECTO AL MODELO CLÁSICO}

Con respecto a la temática guerrera en las dos obras, observamos que en la translatio se han suprimido numerosos relatos que aparecen en la fuente clásica o se han modificado para adaptarlos a la mentalidad medieval. Estos cambios se aprecian en Enéas desde los primeros episodios, precisamente relacionados con el tema de la ira de Juno y sus estructuras míticas.

Así, muchos de los eventos mitológicos más relevantes como son el Juicio de Paris y la petición de armas a Vulcano por parte de Venus, cuyo tratamiento y funciones presentan diferencias entre ambas obras, permanecen en el texto medieval, debido a su gran importancia en el desarrollo de los acontecimientos. Sin embargo, en el caso de la diosa Juno, muchas de sus actuaciones en relación a la trama guerrera están suprimidas parcialmente en la obra medieval. Su intervención se desvanece en Enéas, cuando acaba el episodio de Cartago, y todas las intervenciones de Juno que aparecen en la Eneida se omiten para convertirse en hechos que suceden por el destino o el azar, ya no por la intervención directa de la diosa.

La importancia de la diosa Juno en la novela medieval queda limitada a su deseo por convertir Cartago en la ciudad más poderosa. Las actuaciones que realiza anteriores al desembarco de Eneas en Cartago se omiten. La primera parada de Eneas, se efectúa en tierra hostil ya que Juno odia a los troyanos; así de manera indirecta marca negativamente el principio del viaje del héroe, un viaje lleno de adversidades hasta su llegada a la tierra prometida. Este primer desembarco en tierra hostil marca, junto con la primera etapa de Eneas, un episodio negativo en la trayectoria del héroe:

\section{La deesse Juno voloit}

\section{Que Cartage fust chiés del mont}

Et li fussent trestuit aclin,

Mais onques n'i pot metre fin ;

Tot autrement est destiné.

(V. 520-525)

La supresión de ciertos episodios mitológicos en Enéas se debe al poco interés que pudiera despertar la abundancia de elementos paganos para el lector medieval y, 
también, por lo poco que aportan al desarrollo narrativo de los acontecimientos ligados a la trayectoria del héroe, considerada dentro del prisma medieval.

También constatamos que la ira de Juno, presente hasta el final de la obra clásica, se diluye desde el descenso a los Infiernos del protagonista en la obra medieval. El autor de la translatio centrará sus esfuerzos narrativos en Eneas y en la conquista de su destino, dejando a un lado las intervenciones divinas y centrando la trama en su acción individual y su constitución en caballero ideal. Así, lo que para la Eneida es fruto de la intervención divina, para el Roman d'Enéas es fruto de la simple naturaleza, minimizándose la carga mitológica para centrarse en el protagonista, Eneas.

Hay que señalar que todos los episodios de la Eneida en los que aparece Juno constan de una misma estructura: Juno observa a los troyanos y su ira motivada por el Juicio de Paris no le deja abandonar su empeño en acosar a Eneas y a los suyos. Bien mediante la ayuda de los dioses, bien mediante la ayuda de otro personaje secundario, le pone trabas a Eneas en su conquista de la tierra prometida por los dioses, desobedeciendo a los dioses y más concretamente a Júpiter. La ira de Juno en la obra clásica está motivada por el Juicio de Paris, de ahí su importancia y su presencia en la obra. Este es el esquema que utiliza Virgilio para la intervención de la diosa en la trama narrativa:

Pero Juno, en la cima del otero que ahora se llama Albano (...) oteando la llanura avistaba las huestes laurentinas y troyanas formadas ya en la batalla y la ciudad del rey Latino. De pronto se dirige a la hermana de Turno. (Eneida, Libro XII, V. 134-139).

El primer obstáculo que Juno impone a Eneas en la obra clásica, lo elabora la diosa con ayuda de otro dios: el dios del viento, Eolo. Éste crea una gran tormenta para que encrespe el oleaje y Eneas tenga dificultades para navegar; a cambio de este favor Juno promete a Eolo una ninfa: Deyopea. Eolo acepta y provoca una gran tormenta que hace desesperar a Eneas y a los suyos hasta la intervención de Neptuno. El dios del mar y de las profundidades marinas apacigua el temporal y los pone a salvo de la tempestad.

Frente a esta multiplicidad de divinidades y la presencia de una ninfa (Juno, Eolo, Neptuno y Deyopea), el Roman d'Enéas recrea este episodio de modo más breve 
y todo el peso mitológico desaparece. Así, tras su huida de Troya, Eneas se echa a la mar y se desata la tormenta:
A un jor li mut Grant tempeste,
Car molt formant comut la mer;
Les nes comancent a vaucrer,
Tone et pluet, vante esclaire,
Molt comança lait tens a faire,
Chieent foldres espessemant,
Comeüe est la mers formant ;
Si fait oscur ne voient gote.

(V. 188-197)

Se suprime así la conversación con Eolo y su pacto, minimizando la carga mitológica, a diferencia de Virgilio que multiplica la intervención divina para otorgarle a su obra mayor valor histórico.

Otra diferencia con la Eneida reside en la forma en la que la tormenta desaparece. Si para la Eneida es otra vez la intervención divina, siendo en este caso el dios Neptuno quien hace que la tormenta desaparezca, en el Roman d'Enéas no hay rastro de ningún dios y la tormenta desaparece naturalmente al cabo de tres días:

\author{
Ansi ont fuitis de Troie \\ Sofert trois jors, qu'il n'orent joie ; \\ Quant vint al quart, qu'il ajorna, \\ Li vanz failli, del tot cessa, \\ Li solaus lieve, ne plut mes, \\ Del tot remest la mer an pes ; \\ Asoagiee est la tenpeste.
}

(V. 263-269)

Otro de los episodios relacionados con la ira de Juno, e inexistente en el Roman d'Enéas, es el de las mujeres troyanas. Después de la huida de Cartago, Eneas llega a Sicilia; allí Juno intenta saciar su ira a través de las mujeres troyanas que van a incendiar las naves de Eneas. El poeta presenta a las mujeres troyanas en la playa, en un 
lugar separado, entregadas al dolor por la pérdida de Anquises, aisladas del espectáculo de los juegos que estaba reservado a los hombres. Juno aprovecha esta ocasión para saciar su rencor e incita a las mujeres, haciéndose pasar por una de ellas para que quemen las embarcaciones; a través de Iris se transforma en una más de las mujeres troyanas e intenta convencer al resto para que quemen las naves de Eneas e impedir que los troyanos lleguen a Italia. Sin embargo, una de ellas se da cuenta de su aspecto divino y alerta a las demás:

"No troyanas, no es ésta Béroe, no es la esposa retea de Doriclo. Observad las señales de su gracia celeste, el brillo de sus ojos, qué aire de majestad, qué semblante, qué tono de voz y su porte al andar. (...) De repente la diosa planeando sus alas, se remonta por el cielo y en su huida va hendiendo por las nubes su arco ingente." (Eneida, Libro V, V. 645-656).

La supresión del episodio mitológico sin duda contribuye a poner de relieve la intencionalidad del texto medieval orientado a la individualización y ejemplaridad del personaje, dando así mayor amplitud y autonomía a la actuación del individuo frente a su adversidad, actitud más propia del género novelesco que del género épico. En su lugar, en el texto medieval aparece descrito con todo lujo de detalles el descenso de Eneas junto con la Sibila a los Infiernos, momento simbólico para la obra y para el destino del protagonista.

Así en la Eneida, la comunicación de los dioses con los mortales se realiza bien a través de mensajeros (Mercurio), bien a través de divinidades menores (Iris, Alecto o Cupido) o bien de manera velada, es decir haciéndose pasar por mortales y ocultando su procedencia divina. En la obra medieval, casi siempre la comunicación directa con los dioses va a ser a través del papel tradicional de un mensajero, y la divinidad nunca estará en contacto con los mortales; esta variación disipa el carácter divino de los dioses en el texto medieval que aparecen únicamente en los episodios relevantes:

Quant Venus ot tot receü,

Halberc et hialme et escu,

Chauces et lance et espee,

A son mesage les charja, 
A Eneas les anvoia

A Montauban, ou il estoit

(V. 4543-4550)

Otra intervención de Juno, suprimida en el Roman d'Enéas, se corresponde con un episodio importante en la Eneida, en el que Juno, por medio de la furia Alecto, excita la ira de la reina Amata y de Turno. A imitación de Juno, Alecto incita a la reina y a las mujeres del Lacio a que obliguen al rey a declarar la guerra a Eneas:

Va volando la fama. Enardece de furia a las matronas. A todas les acucia un ardoroso afán: buscar un nuevo albergue. (...) La reina en medio de ellas empuña enardecida una antorcha de pino llameante y canta el himeneo de su hija y Turno. (Eneida, Libro VII, V. 392-394).

En el análisis de las supresiones relacionadas con la diosa Juno observamos que todas las intervenciones de Juno en la batalla se omiten totalmente en la obra medieval: así la excusa para empezar la lucha, la herida del ciervo, no nace de la casualidad de que Ascanio sale de caza y se cruza con él, como expone el Roman d'Enéas (v. 3565-3592), sino que es otra vez Alecto quien hace que Ascanio se cruce con él y lo hiera de muerte provocando así la guerra. Aquí es la inocente juventud de Ascanio la que topa con la casualidad o la mala suerte. Suprimiendo la intervención divina el autor quiere dar más realismo a una escena que, por otra parte, se repetía muy a menudo en la Edad Media ya que la caza era una actividad de primera importancia y a menudo fuente de conflicto. Se justifica la supresión de estos episodios no sólo por la falta de conexión de la mitología clásica con la mentalidad medieval sino también por alejarse de la autenticidad reivindicada por el autor con respecto a la fuerza y suficiente sabiduría del propio héroe.

El libro X de la Eneida acaba con la intervención divina y la reunión de los dioses, en la que Júpiter decide mantenerse al margen de la lucha y dejar que el destino, como en el Roman d'Enéas, sea el que decida la suerte de cada uno. Esta asamblea de los dioses, que culmina con las intervenciones de Juno, está suprimida y en su lugar el autor medieval se centra en la descripción de la batalla final que dará la victoria a Eneas, acercándose al estilo épico para engrandecer al héroe y sus hazañas. 
El Roman d'Enéas concluye con la lucha de Eneas y Turno, después de que los hombres de éste lo abandonen y decidan dejar de luchar por su causa. Eneas se proclama vencedor, culminando así por sí solo su trayectoria, su destino:

Fortune torne en molt po d'ore,

Tel rit al main qui al soir plore;

Al soir est laide, al matin bele,

Si com el torne sa roëlle ;

Cui al met a l'un jor desus,

A l'autre lo retorne jus :

De tant com el l'a mis plus halt,

Tant prant il aval graignor salt.

(V. 685-692)

Pero, a pesar de que Juno aparece difuminada en la última etapa del Roman d'Enéas con respecto a la temática guerrera, aparece metafóricamente representada en la unión de Eneas y Lavinia, dado que ahí se puede aludir a otra de sus facetas: la de diosa protectora del matrimonio:

Quant li reis l'ot de li saisi

Et el de lui, se fist molt liee ;

La feste fu molt esçauciee ;

Les noces durerent un mois.

De sa terre esgarda li rois

Del mialz une molt grant partie,

La ou Eneas l'a choisi ;

An son vivant otroia.

(V. 10120-10127)

La supresión de divinidades en la obra medieval no es la única importante que realiza el autor con respecto a su fuente. Se suprime también el libro III de la Eneida, correspondiendo al viaje que emprende Eneas después de su salida de Troya y que le lleva de Frigia a Sicilia. Se prescinde del desembarco en Tracia, su huida a Delos, su paso por Creta, su llegada a las islas Estrófades, Butroto y desde allí su salto a Italia. Este viaje plagado de alusiones a la mitología clásica se ha suprimido totalmente en la 
obra medieval por su escaso interés, tanto para el público de la época como para el autor, cuyo objetivo, como ya hemos dicho, es ensalzar la figura de Eneas.

El devenir de Eneas por el mar, y sus desembarcos en las diferentes tierras, se sintetiza hasta que alcanza su parada en la tierra de Dido, Cartago, que proporciona al protagonista una visión de la ciudad medieval ideal, la cual querrá imitar en la fundación de la nueva Troya, así como la representación de la primera figura real encarnada en una mujer, Dido, que ostenta todos los valores de un rey, aunque no todos por tratarse de una mujer, que se nos presenta a la vez como doble de Eneas y que posee lo negativo del género femenino. Todo ello le mostrará al guerrero las cualidades a adoptar en su destino final y las tentaciones a sortear, lo que proporciona directamente al autor la posibilidad de revelar a sus lectores el comportamiento erróneo de un caballero.

La ciudad de Cartago está muy ligada a la personalidad del héroe al mostrarle en cierta manera el final de su destino en la figura de Dido, al igual que él, expulsada de su reino y con la labor de fundar uno nuevo, aunque de una forma imperfecta al tratarse de una mujer. Esta digresión perfila en Eneas la fundación de una tierra después de un destierro, destino por el que luchará a lo largo de toda la novela medieval.

También Cartago supone una iniciación en lo que se refiere a la figura de rey que ostentará Eneas después de la fundación de su patria, preparándose en el gobierno de la ciudad y en su construcción y defensa. Así, esta etapa «constituera cependant pour Eneas, qui s'est séparé métaphoriquement du droit chemin, la condition nécessaire à l'obtention du point final de sa trajectoire ${ }_{96}{ }^{\text {". }}$

Al analizar las supresiones realizadas por el autor medieval, se refuerza la idea de la reutilización de una figura clásica para el soporte de la caballería y de sus ideales, apoyándose en los mitos y adaptándolos para su reutilización en la sociedad medieval, creando un nexo de unión entre la mitología clásica y el imaginario medieval que apoya sus ideales en figuras de héroes clásicos de gran notoriedad. De esta forma, el autor de 
Enéas logra «modifier durablement l'image que les médiévaux se sont forgée de l'Enéide ${ }_{97}{ }^{\gg .}$

Por otra parte, un episodio aumentado en la novela medieval frente a la fuente clásica, y que tiene gran importancia en el enfrentamiento de Eneas contra Turno, es la ira de la madre de Lavinia, que se justifica no por causas divinas, como en el fragmento clásico, sino por su propio prejuicio para con Eneas, fundado en la mala reputación y en su origen extranjero; ella conoce su pasado con Dido y además sabe que Eneas carece de posesiones y de riquezas para aportar al matrimonio. Pues su odio se evidencia de manera natural y subjetiva; no hay razones para pensar que está instigado por ningún dios como en la Eneida. En efecto sus argumentos son propios de la mentalidad medieval:

Se ta fille li vels doner,

\section{Il la prendra molt liement,}

Mais ja si tost n'avra buen vent,

Com il la vos avra guerpie,

Molt l'en ert pou s'il l'a honie.

De lui n'atendre tu ja el,

Il a aillors fait altretel:

Dido la dame de Cartage

Mar vit onques le suen ostage ;

Il fist de li sa volenté

(V. 3302-3311)

Después de ver de manera general los cambios, salvo en alusiones puntuales con respecto al modelo clásico de Enéas, centradas en la figura mítica de Juno que se desvanece en la obra medieval o en ciertos episodios aumentados para reflejar características de la mentalidad de la época, pasamos a analizar a través de una relectura de la obra clásica, los elementos temáticos que conserva la novela y las variantes que efectúa, alrededor del personaje central. 


\subsubsection{El HÉROE EN ENÉAS Y LA ENEIDA}

En el apartado anterior apuntamos los episodios omitidos en la obra medieval con respecto a la mitología clásica, especialmente los que tienen que ver con la diosa Juno y crean situaciones de enfrentamientos entre los personajes. En este punto, no sólo señalaremos las variantes formales sino que nos centraremos principalmente en el tratamiento del personaje principal, Eneas, analizando su trayectoria guerrera.

Antes de comenzar con el análisis del personaje principal, hay que señalar ciertas variaciones con respecto a su hipotexto que marcan ya desde el inicio las diferencias entre las dos novelas. La obra clásica omite la huida de Eneas de Troya, y se centra en las penalidades que le hace pasar la diosa Juno, presentándonos los motivos de su ira contra el guerrero troyano. Sin embargo la novela medieval relata la huida de Troya de Eneas y la destrucción de la ciudad: de esta forma empieza in media res, priorizando a la vez la destrucción y la guerra, ya desde sus primeras páginas, y la figura de Eneas como prototipo de caballero. Con esta variación formal respecto a su fuente, el autor medieval da prioridad a la figura del caballero encarnado en Eneas.

Para realizar el del personaje principal Eneas es necesario un estudio de las diferencias formales que afectan en la forma de tratar al héroe. La primera gran diferencia reside en el comienzo de ambos textos:

Eneida (Libro I, V.13-32):

"Hubo de antiguo una ciudad, Cartago- se asentaron en ella emigrantes de Tiro-, frente a Italia, a lo lejos de la boca del Tiber, opulenta, feroz como ninguna en empeños guerreros. Dicen que Juno la prefirió entre todas. Samos viene después. Allí tuvo sus armas, allí tuvo su carro de guerra. Desde entonces ponía su ambición y sus desvelos en hacer de ese reino el señor de la tierra, si accedían los hados a sus planes. Pero \$había llegado a sus oídos que de sangre troyana provenía la raza que un día llegaría a derrocar los alcázares tirios; de ella el pueblo señor de anchos dominios, soberano en la guerra, que arrumbaría a Libia. Era designio que giraban las Parcas 98 .

98. "Las Parcas que sugiere « las que dan a cada uno su parte », son las diosas encargadas de señalar y ejecutar el destino individual, para los mortales la muerte ante todo", Ruiz de Elvira, A., Mitología clásica, Madrid, Editorial Gredos, 2011 , p.87. 
Temerosa de este presagio, la hija de Saturno traía a su memoria la guerra que otro tiempo libró por sus queridos argivos ante Troya. No se habían borrado de su mente las causas de su enojo ni su amargo pesar. Queda en lo hondo de su alma fijo el juicio de Paris y el injusto desprecio a su hermosura y el odio a aquella raza y el honor dispensado a Ganimedes99. Quemada aún más por esto, iba acosando por todo el haz del mar a los troyanos, -los restos que dejaron los dánaos y el iracundo Aquiles- y los iba manteniendo alejados del Lacio. Largos años llevaban errantes, rodando por los mares, juguete de los hados.

Enéas:

Quant Menelaus ot Troie asise,

Onc n'en torna tresqu'il l'ot prise,

Gasta la terre et tot le regne

Por la vanjance de sa fenne.

La cité prist par traïson,

Tot cravanta, tors et donjon,

Arst le paiis, destruist les murs,

Nus ne estoit dedanz seürs;

Tote a la vile cravantee,

A feu, a flame l'a livree.

(V.1-10)

Eneas n'estoit pas seürs;

Dous granz liues et plus avoit

De la ou sa meison estoit

Desi la ou li Greu ardoient;

Bien set qu'il li aprismeroient,

99. Ganimedes de quien se enamora Zeus, es raptado por el águila de Zeus ( o por Zeus convertido en águila) y llevado al cielo para escanciar eternamente el néctar; en compensación Zeus da a Tros unos caballos divinos, que son los que más tarde pedirá Hércules como precio por salvar a Hesíone del cetáceo. Ibid., p. 453. 
Ne se porroit vers als deffendre.

Bel loisir ot del suen tot prendre, Tote sa gent fist asenbler

Et ses tresors an fist porter;

Grant avoir et grant manantises

Et granz richeces an a prises,

Par un postiz s'an est issuz,

Bien en torna trois mille escuz;

A soi an fist porter son pere

Anchisés, qui molt vialz hom ere,

Et par la main mena son fil:

cil sunt livré a grant essil.

Soantre lui grant gent la'n vait;

La ou il fuit se sunt atraint.

(V.41-60)

Al comparar los dos inicios, nos damos cuenta de la primera diferencia: en la Eneida se expone el odio de Juno hacia los troyanos y su causa, además de intercalar ciertos datos mitológicos, totalmente ausentes en la novela medieval; por otra parte, se ensalza desde las primeras páginas la nobleza de la raza troyana: había llegado a sus oídos que de sangre troyana provenía la raza que un día llegaría a derrocar los alcázares tirios; de ella el pueblo señor de anchos dominios, soberano en la guerra, que arrumbaría a Libia. La novela medieval al optar por eludir la mitología se centra en Eneas desde su inicio.

Otra de las diferencias es la mención al juicio de Paris como causa de la ira de Juno, alusión que no aparece hasta el verso 100 en la novela medieval en la que el autor relata de forma breve, en 83 versos, el Juicio de Paris, como causa principal de la destrucción de Troya.

En lo que respecta a la novela medieval, se muestra un carácter negativo hacia la actitud del héroe troyano en su primera etapa que termina con el descenso a los Infiernos, donde se representa desde una perspectiva mítica su destino anunciado ya en las primeros versos, hecho que coincide en las dos obras; en la clásica, expuesto este designio por las Parcas y, en la medieval, expuesto por los dioses y transmitido al troyano a través de su padre. 
Mencionadas estas diferencias notables en lo que concierne a forma y temática, nos centraremos en la figura principal de Eneas en los dos textos, analizando la variación que se puede detectar entre los dos autores.

ENEAS EN LA ENEIDA

Claras diferencias aparecen entre la Eneida, a la hora de describir la actitud de Eneas, y la novela medieval. Para justificar este cambio de visión me he detenido en todas las características que nos ofrece la Eneida de este personaje, bien a través del narrador o a través de otros personajes, para después confrontar con la transformación que sufre en la novela medieval.

\section{Libro I}

El libro I muestra la lucha de dioses y hombres y la inferioridad de los troyanos, el sufrimiento de Eneas para conseguir su destino. Eneas está caracterizado como un personaje luchador, jefe de su ejército que anima a sus hombres y les da esperanza ante las adversidades: nos muestra un guerrero al frente de sus hombres. En estas palabras Eneas destaca entre sus compañeros como el jefe valiente que anima a sus hombres ante las penurias que están pasando:

“¡Compañeros, ya hace tiempo que no somos ajenos a desgracias! Habéis sufrido trances más penosos. Un dios pondrá fin también a los presentes. Vosotros que llegasteis a acercaros a la rabiosa Escila, al hilo de sus rocas de profundos ladridos resonantes, vosotros que arrostrasteis los riscos de los Cíclopes, recobrad vuestros ánimos, desechad el temor que os contrista. (Eneida, libro I, Versos 198-202)".

Sus hombres también tienen buenas palabras hacia Eneas; éstas son las que profieren en su llegada a Cartago para presentarle:

"No son tan agresivos ni de tanta arrogancia unos vencidos." (Verso 529) 
“Nuestro rey Eneas. Jamás lo hubo más recto ni de mayor bondad, ni más grande en la guerra y en el manejo de las armas." (Versos 544-545)

Por otra parte, Dido también manifiesta su opinión del troyano con su visión favorable al guerrero:

“¿Quién hay que no conozca el noble pueblo de Eneas? ¿Quién no sabe de la ciudad de Troya, sus hazañas, sus héroes y los incendios de su fiera guerra?” (Versos 564-566)

A lo largo de este libro I no hay ningún adjetivo que califique a Eneas de cobarde al haber huido de Troya sin luchar. Su huida se justifica por su destino: fundar una nueva ciudad. Las características negativas están ausentes en la primera etapa de Eneas en la obra clásica.

\section{LIBRO II Y LIBRO III}

El libro II y III cuentan la guerra de Troya de boca de Eneas, continúa la visión positiva del héroe que intenta disculpar su huida por lo inesperado del ataque y las pocas esperanzas de triunfo. Esta idea está apoyada por la intervención de su padre que le anima a huir. En el libro III se describe la actitud de Eneas ante su destierro obligado, y los diferentes viajes durante los siete años que vaga por los mares. El destino de Eneas está decidido por los dioses, no por él, hecho que está muy patente en la obra clásica.

\section{LIBRO II}

"Vosotros cuya sangre no han frenado los años todavía -prorrumpe-, cuyas fuerzas se mantienen pujantes en su vigor primero, vosotros emprended la huida." (Versos 638640).

"¿ Para esto madre mía valedora, me arrancas de entre dardos, de entre llamas, para que llegue a ver al enemigo en medio de mi casa, y a Ascanio y a mi padre y a Creúsa junto a ellos, degollados, bañados los unos en sangre de los otros?; Las armas, escudero, traedme acá las armas! El día final llama a los vencidos. ¡Dejad que vuelva 
en busca de los dánaos! ¡Dejadme que reanude la lucha! No vamos a morir hoy todos sin venganza, lo aseguro" (Versos 664-670).

"Y mi padre adentrando en las sombras su mirada me da voces: “¡Hijo mío, hijo mío, huye, se acercan!" (Versos 733-734).

\section{Libro III}

En este pasaje se nos presenta a Eneas como a un héroe más que un fugitivo, su figura en toda la Eneida está caracterizada por la de un hombre cuyo destino está fijado por los dioses.

"Abandoné llorando las playas de la patria y los puertos y la llanura donde estuvo Troya. Me llevan desterrado mar adentro con mis hombres y mi hijo y los Penates y con los grandes dioses." (Versos 10-12).

Constatamos con la lectura de este libro que los viajes y las aventuras que Eneas sufrió durante los siete años por mar; fruto de la ira de Juno, están omitidos en la novela del siglo XII.

\section{LIBRO IV}

Este libro nos expone la opinión de Dido respecto a Eneas y la de la hermana de ésta, ambas actitudes positivas. Aparece en este libro la primera crítica a la actitud de Eneas de boca de los dioses, al no haber seguido su destino.

"Da vueltas y más vueltas en su mente a las prendas de Eneas y a su gloriosa alcurnia." (Versos 3-4).

"¿Quién es ese huésped que acaba de entrar en nuestra casa? ¡Qué gallardo su aspecto! ¡Qué valiente y qué diestro en las armas! Lo creo, sí, no lo aseguro en vano, es de raza de dioses. El apocado revela su alma ruin. ¡Ay que hados lo han vejado! ¿Qué guerras ha contado, afrontadas por él hasta el último trance!’ (Versos 11-14). 
Todos los adjetivos califican a Eneas de luchador, de buen guerrero; todas estas características son expuestas por una mujer enamorada:

“¿Qué tramas? ¿Qué esperanza te mueve a mal perder tu vida ocioso en estas tierras libias? Si la gloria de tan altas empresas no te incita ni abrazas sus fatigas acuciado por tu propia alabanza, (....) Enmudece Eneas a su vista, se queda sin sentido, se le erizan de espanto los cabellos, se le pega la voz a la garganta, arde en deseos de huir, de abandonar aquella dulce tierra, atónito ante el golpe del aviso y el mandato divino." (Versos 271-282).

\section{LIBRO V}

Eneas se enfrenta a su destino sin saber su final y sin perder el coraje; indirectamente el texto nos muestra un personaje valiente ante un futuro incierto:

"Eneas a lo largo de la playa convoca una asamblea de los suyos y desde un altozano les habla así: “;Nobles hijos de Dárdano, nacidos de la raza egregia de los dioses, ha completado el año la carrera de sus meses cabales, desde que confiamos a la tierra los huesos, lo que de él nos quedó, de mi padre divino, y nuestro duelo consagró estas aras. "Y ya, si no me engaño llega el día para mí siempre amargo, que he de honrar siempre, así lo habéis querido, dioses. Yo aún desterrado entre las Sirtes getulas, o sorprendido en medio del mar de Argos o en la misma Micenas, cumpliría mi promesa cada año, celebrando conforme a lo prescrito solemnes ceremonias y colmando este día los altares con los dones debidos." (Versos 46-54).

\section{LIBRO VI}

La transformación del héroe es evidente, continúa la imagen positiva de Eneas y su valor ante la adversidad y es él mismo el que pide bajar a los Infiernos con los peligros que ello conlleva:

“Tan pronto como cesa su furia y se apacigua la rabia de su boca, comienza a hablar el héroe: "Ninguna traza de sufrimientos, virgen, me resulta nueva ni inesperada. 
Todos los he previsto y sopesado en mi alma de antemano. Ya que, según se dice, es ésta la puerta que conduce al rey de las regiones inferiores y al tenebroso en que refluye el Aqueronte, sólo pido una gracia: poder llegar a ver a mi padre querido cara a cara, que me enseñes el camino y descorras las puertas sagradas a mi paso". (Versos 103-109)

Siguen los buenos calificativos:

"El troyano Eneas, afamado por su piedad y su valor guerrero, baja al hondo del Érebo sombrío en busca de su padre. Si no te mueve el alma el dechado de tal amor filial, reconoce a lo menos este ramo." (Versos 403-406).

\section{LIBRO VII}

En este episodio comienza la guerra, con el accidente de Ascanio que hiere al ciervo de Silvia. Comienza el desfile de pueblos que apoyan a Turno y diferentes combates.

\section{LIBRO VIII}

Este libro muestra nuevamente diversos adjetivos que describen positivamente a Eneas como los que expresan Palante (en la novela medieval Palas) y Evandro. Aparece un episodio mitológico relevante para un caballero: la petición de Venus a Vulcano de armas para Eneas, episodio retomado en la novela medieval y que apoya el carácter guerrero de Eneas. Aparece el caballero Palas, que dará lugar a un nuevo ejemplo de ideal de caballero para la novela medieval:

“¿Qué a gusto te acojo y reconozco en ti al más valeroso de los teucros! ¡Cómo vuelve a mi mente la manera de hablar de tu padre, el gran Anquises, u voz sus facciones! Lo recuerdo. Fue durante aquel viaje que hizo Príamo, el hijo de Laomedonte, al reino de Hesíone, su hermana, a Salamina y pasó desde allí a la helada comarca de Arcadia (...)" (Versos 154-159) 
En este libro aflora el episodio de la entrega de armas a Eneas por parte de Venus. En la Eneida este episodio se minimiza mientras que en la novela medieval será uno de los episodios claves, donde aparecen descritas todas las armas, siguiendo las directrices de la sociedad guerrera en la que se crea esta obra.

El caballero medieval se caracteriza no sólo por sus cualidades morales como la lealtad, la valentía y el coraje sino que, desde un punto más materialista, otra característica importante son las armas que lo diferencian de las otras clases sociales en las que se divide la sociedad medieval. Por ello, el autor de Enéas, al mostrar el ideal de caballero, no puede omitir la descripción de las armas, a la que dedica más de 100 versos (de forma ordenada y graduada de mayor a menor importancia en el combate). Sólo aparecerá dos veces la descripción de armas, relacionada con Eneas y Camilla, dos ideales de caballeros en la novela, el segundo trastocado por su condición de mujer. Este hecho le sirve al narrador medieval para extender su descripción ya que las armas son parte fundamental y significativa del estatus de caballero.

\section{LIBRO IX}

Narra el episodio de Niso y Euríalo. Dos de los guerreros que, a pesar de ser secundarios, representan los ideales de los caballeros y de la amistad. Este episodio que aparece en la obra clásica se conserva en la medieval ya que le permite al narrador explotar en otros personajes los ideales de buen caballero medieval.

\section{LIBRO X}

En este libro se ensalza la figura de Palas, otro de los guerreros que ostentan un papel fundamental en el desarrollo de la acción. El joven guerrero, al que le da muerte Turno, muestra en el combate la lealtad y la valentía propias de guerreros veteranos. Este libro muestra la actitud de venganza de Eneas tras la muerte de su compañero y la actitud negativa de Turno al quitarle el anillo a Palas, ya herido de muerte, y mofarse del padre del guerrero. Este hecho se reutilizará como justificación de la muerte de Turno a manos de Eneas en la obra medieval. 
“Turno a su lado en pie prorrumpe: "Arcadios, recordad lo que os digo y trasladadlo a Evandro. Le devuelvo a Palante tal y como se lo tiene merecido. El honor del sepulcro, cualquiera que éste sea, y el consuelo que puede deparar el dar tierra a un cadáver, se lo otorgo generoso. No le va a costar poco la acogida de Eneas." (V. 490-494)

\section{LIBRO XI}

En este libro aparece un personaje femenino fundamental en la temática guerrera y al que la novela otorgará un papel muy importante a pesar de que, por su condición de mujer, en la sociedad medieval apenas tenga importancia; pero sigue formando parte del grupo de caballeros que representan los ideales guerreros medievales.

"Veloz viene a su encuentro la amazona Camila entre la escolta de su escuadrón de volscos. Ante las mismas puertas de un salto descabalga la reina. Toda la comitiva la imita. Se deslizan en tierra dejando sus monturas. Y asi le habla ella "Turno, es justo que el valiente confie en su valor, yo segura de mí me atrevo, lo prometo, a correr al encuentro del escuadrón de Eneas y acometer yo sola a los jinetes tirrenos. Déjame que afronte con mi brazo los primeros peligros de la guerra. Tú quédate a pie firme ante los muros guardando la ciudad." (V. 497-506):

\section{LIBRO XII}

Termina la Eneida con el combate final entre Eneas y Turno y la muerte de éste. La lucha entre los dos guerreros le proporciona su destino a Eneas. Sin embargo no se cierra la obra con la fundación de su nueva patria, sino con la muerte de su enemigo. El personaje de Eneas justifica con sus hechos todos los adjetivos que a lo largo de la novela lo han caracterizado, tanto por el narrador como por todos los personajes que coinciden con el héroe en sus diversas paradas.

“Lavinia es tuya. No lleves más lejos tu rencor”. Feroz en su armadura, revolviendo los ojos, en pie, frena Eneas su diestra. Y ya el ruego de Turno comenzaba a ablandar su ánimo cada vez más vacilante, cuando aparece a sus ojos en lo alto del hombro del caído el tahali infortunado y refulge en su cinto el oro de las bolas que le eran 
conocidas. Era el tahali del joven Palante, al que Turno logró herir y vencido postró en tierra. Él lo ostentaba por divisa fatal sobre sus hombros. Cuando Eneas fue hundiendo la mirada en el trofeo, en aquel memorial de su acerbo dolor, ardiendo en furia, en arrebato aterrador: “¿Y tu, vistiendo los despojos de aquel a quien yo amaba, te me vas a escapar de las manos? Es Palante, el que con esta herida va a inmolarte y se venga en tu sangre de tu crimen" (Versos 938-949).

\section{ENEAS EN ENÉAS}

Siguiendo la idea expuesta por Léopold Génicot en el prefacio de L'essor de la chevalerie XI-XII siècles, podremos observar en la figura de Eneas la evolución de la caballería: "Après la préhistoire de la chevalerie, son histoire. Celle de sa lente constitution, à travers les XI et XII siècles, en un groupe ou plutôt un ordre ; avec sa fonction sociale ou sa mission, voire sa vocation, héritée des rois et des princes qui, au tournant de l'an mil, se sont substitués à ceux-ci ou ont rivalisé avec eux; avec son mode et son code de vie, calqués sur ceux de la noblesse; avec finalement son rite d'initiation, l'adoubement, où l'élément religieux ne s'affirmera, se développera, prendra le pas qu'après $1200_{100}{ }^{»}$. A través del análisis, vamos a ver materializadas las distintas etapas del caballero así como sus ideales, observando en el género literario un espejo de la sociedad en la que se produce.

En un primer momento, al comparar las dos obras, la clásica y la medieval, apreciamos el diferente tratamiento que se hace del guerrero troyano, cuyo estudio en la obra clásica hemos realizado en el apartado anterior. Hemos visto a un personaje que, debido a su destino, huye de su patria. En Enéas, se presenta al héroe troyano como ejemplo de caballero medieval, a través de su actitud, desde su huida hasta la fundación de su nuevo reino, dando una serie de reglas a alcanzar para sus lectores, siguiendo su camino hacia la iniciación de buen guerrero; Eneas se convierte así en el modelo.

En este sentido, vamos a ver las variaciones en los calificativos del héroe troyano en la novela medieval, a lo largo de las diferentes etapas que sufre el personaje, 
así como su evolución a través de las fases que coinciden con su huida de Troya, el descenso a los Infiernos y la fundación de su nueva patria, es decir, ver cómo se produce en estas tres etapas la evolución del protagonista dentro del Roman d'Enéas.

\subsubsection{HUIDA DE TROYA}

La primera etapa de nuestro análisis coincide con el inicio de la novela; esta parte ocupa unos 2144 versos y engloba varios episodios de gran relevancia en la narración: travesía de siete años por el mar sufriendo el acoso de Juno, desembarco en Cartago, historia de amor entre Dido y Eneas y, finalmente, el suicidio por amor de Dido. Al inicio de esta novela el lector se encuentra con un mundo devastado, etapa propicia para el renacer del héroe y el comienzo de su iniciación.

Nuestro estudio se centra en los diferentes calificativos que recibe Eneas en su primera etapa. La primera característica que se nos muestra en el personaje de Eneas, es la de líder al igual que en la obra clásica. Eneas toma el mando en la huida de su reino y lo mantendrá durante toda la novela, animando siempre a sus hombres en la adversidad. Aparece como elegido por los dioses para crear una nueva patria y guiar a los suyos en su nueva etapa. La primera característica del caballero aparece en él en los primeros versos de la novela, a pesar de la imagen negativa debida a la huida sin combate de su patria.

So antre lui grant gent la'n vait,

La ou il fuit se sunt atrait.

(V. 59-60)

\section{Donc a Eneas asanblé}

Çaus qui o lui sont arivé;

Nan i ot de sa compaignie

Ne mes que la tierce partie;

Çaus comança a conforter

Des maus qu'il oren an la mer

(V. 305-310) 
El héroe se ve solo ante la adversidad y, junto con sus compañeros, intenta conseguir sus metas. Se encuentra en un medio hostil, donde Juno lanza toda su ira contra ellos; en este combate desigual se intenta forjar la personalidad guerrera de Eneas. Desde su huida de Troya, en la novela medieval se desmarcan una serie de etapas a lo largo de la trayectoria de Eneas como caballero: la primera manifestación que realza su figura al respecto es su aceptación como líder del grupo:

Quant de la vile sunt estors,

Desoz un arbre loing defors

O soi a alié sa gent;

Demande a toz comunaument

S'il se voldront o lui tenir

Et bien et mal lui sofrir,

Ou s'en voldront retorner anz

Vangier la mort de lor paranz;

Prez est de faire lor plaisir

Del retorner ou del foïr.

(V. 61-70)

Aparece en esta primera fase el sufrimiento durante los siete años que perdura el asedio de Juno cuya figura es desdibujada en la novela medieval, como hemos visto en el punto anterior. La dureza de las pruebas que sufre Eneas se refleja en los ánimos de sus hombres que muestran su desaliento ante la situación que les ha tocado vivir. Aparece aquí la segunda característica del caballero medieval, reconfortar a sus hombres ante la adversidad. Eneas empieza a comprender la dureza de su destino:

"Seignor", fait il, "franc chevalier,

Ne vos devez mie esmaier

Se vos avez eü peor

An ceste mer, mal et dolor;

Ça avant vos delictera,

Quant il vos an remembrera;

Buen vos sera a reconter 


\section{Le maus qu'avez eü an mer}

(V.311-318)

La primera etapa del héroe se cierra con la primera sentencia del narrador que expone la línea de conducta a seguir para alcanzar la meta, la conquista de reinos, y el sufrimiento que implica:

\section{Huen qui s'esmuet an altre terre \\ Por regne et por país conquerre,}

An grant enor ne puet venir,

\section{S'il bien et mal ne puet sofrir.}

Qui toz tens a sa volanté N'onques n'a mal espermanté,

Ce m'est avis, ja ne savra; a negun jor que bien sera; (mais se il sofre un poi mesaise, Qu'il nen a tot ce que li plaise, Ce m'est avis,molt prisera Le bien aprés, quant il l'avra.)

(V. 319-330)

Así, en esta travesía de siete años, Eneas comienza a modelarse como caballero; las pruebas, difuminadas en la novela medieval, pero que lo forjan como caballero contrastan con la carga mitológica con la que aparecen en la obra clásica; ya se aleja la imagen de su huida de Troya y el miedo al ver devastada su ciudad por los griegos:

Quant il a cele noise oïe,

Si regarda vers lo donjon

\section{Et vit la grant destrucion;}

N'est mervoille s'il ot peor.

(V.27-31)

Dentro de esta primera etapa, Eneas desembarca en la ciudad de Cartago, presentada por el narrador como ciudad ideal medieval. Para Eneas, este período le va a 
proporcionar la visión de la construcción de una ciudad medieval en Cartago, y las debilidades de las mujeres al mando en el personaje de Dido, tal y como lo expondrá el autor a lo largo del episodio. Esta etapa cobra un carácter negativo, pero, después de su huida de Troya, es cuando el héroe troyano empieza su iniciación para llevar a cabo su destino.

La imagen de Cartago, que contrasta con la devastada Troya que el autor nos recuerda en los primeros versos de la novela, es la de una ciudad perfectamente edificada, aunque inconclusa, como Eneas. Lugar infranqueable, Cartago es una fortaleza rodeada por el mar y gobernada por una reina extranjera y viuda. Cartago se presenta como una visión metafórica del guerrero, ambos inacabados y en construcción.

Sa cité avoit non Cartage,

En Libe sist sor le rivage.

La mer l'i bat d'une partie,

Ja par de la n'iert asaillie;

de l'autre part sunt li viver

Et li marais grant et plener

Et grant fossez a barbacane

(V. 407-413)

Esta imagen supone una reconstrucción del arquetipo de la ciudad medieval, dotándola de los valores más sublimes e ideales, mezclando lo maravilloso con lo cotidiano, todo ello representado en Cartago, ciudad que reúne todo lo que el caballero busca en su conquista, y sobre todo lo que busca para la reconstrucción de la nueva Troya. El lugar que ocupa Cartago en la narración marca un antes y un después en la iniciación de Eneas que ve en esta ciudad el prototipo de su reino:

Ainz que l'an viegne an Carthage,

A maint destroit et maint passage.

El coig amont devers la rive

Ot une grant roche naïve;

iluec sont li mural assis.

Li carrel sont de marbre bis,

De blanc et d'inde et de vermoil; 
Par grant anging et par consoil

I sunt asis tot a compas;

tuit sont de mabre et d'adamas.

(...)

Tot anviron ot fet trois rans

De magnetes par molt grant sens

D'une Pierre qui molt est dure;

La magnete est de tel nature,

Ja nus hom arrmez n'i venist

que la Pierre a soi nel traisist:

tant n'an venissent o halbers,

ne fussent sanpre al mur aers.

(V. 417-440)

A pesar del estereotipo de ciudad ideal que nos presenta el narrador, Cartago no es la ciudad elegida por los dioses para la fundación del nuevo reino. Por un lado, la negatividad más evidente de esta ciudad es que está dirigida por una mujer, como lo indica en la segunda sentencia del narrador; por otra parte, Eneas no lo ha conseguido por su lucha como caballero sino como hombre atraído por una mujer. Estos valores negativos pueden justificar el que Cartago no sea la ciudad elegida:

\author{
“Qu'avez trové?- Nos bien. - Et coi? \\ Cartage.- Palastes al roi? \\ Nenil_ Por coi? N'i a seignor. \\ Coi donc?- Dido maintient l'enor.
}

(V.645-648)

Al ser Dido una mujer, no la consideran señor, aunque desempeña todas las funciones de un rey:

Ne puet estre longue par fenne

Bien maintenu enor ne regne;

pou fait an son comandement,

S'il n'a altre maintenant; 
Ne puet mie grant fes sofrir,

S'il li covient guerre baillir.

(V.1349-1354)

Así, a pesar de la perfección de la ciudad, Eneas tendrá que reiniciar su búsqueda de la tierra prometida por los dioses. Supone esta parada un tiempo muerto, especie de prisión para Eneas, ya que en este lugar olvidará el objetivo sustancial de fundar un nuevo reino; al mismo tiempo constituye y una prueba en su maduración como caballero.

De esta forma, Cartago ofrece una pausa narrativa en la que Eneas se nos presenta no sólo como caballero sino también como hombre que se enamora de Dido y olvida sus obligaciones; se impone entonces en él la faceta de hombre antes que la de guerrero. Pero, al mismo tiempo, su experiencia en Cartago le enseña la pervivencia de los valores guerreros, marcando el fin de su aprendizaje, y dando comienzo a la última etapa de su iniciación: el descenso a los Infiernos, etapa fundamental y necesaria para la redención del héroe.

\subsubsection{EL DESCENSO A LOS INFIERNOS}

La segunda etapa de Eneas, tanto desde el punto de vista narrativo como desde el punto de vista de la iniciación del héroe, coincide con el descenso a los Infiernos. El tono trágico de la muerte de Dido pasa a relajarse y Eneas va a penetrar en un mundo desconocido para los hombres. Esta etapa representa el espacio mítico y atemporal en el que se reúnen dos tiempos fundamentales en la vida del héroe: su pasado y su futuro.

En este lugar se produce la parte culminante de su iniciación. En su descenso, Eneas no sólo adquiere el saber sino que se enfrenta a sus acciones pasadas: a la guerra de Troya y a su relación con Dido, dos de sus errores como caballero. El momento de la iniciación de Eneas, claramente orientada a la renovación, se produce en este espacio, en el que la dualidad del bien y el mal está presente en la división entre el Purgatorio y los Campos Elíseos. 
Eneas se reencuentra aquí con su guía, su padre, que ejerce de iniciador y muestra su destino a un Eneas preparado para sufrir las grandes luchas que le esperan. Su futuro está en este lugar, representado por primera vez:

Voiz an ici grant compaignie

Qui doivent prendre mortel vie,

Qui te seront fil et nevoz;

Voiz les, ges te nomerai toz,

Mostrerai toi com il vandront,

Tot an ordre, com il naistront,

En après les te nomerai

Et les batailles te dirai,

Les mals qu'il t'estovra sofrir,

Ainz que puisses a ce venir.

Cel damoisel ki cele lance

Tient an sa main par conoissance,

Cil ira primes de ceüs

Al soverain air la desus;

Lavinia l'avra de toi,

qui est fille Latin lo roi.

(V.2923-2938)

La salida de los Infiernos abre la tercera etapa del héroe. Confirmado el destino, expuesto a través del padre, Eneas adquiere la fuerza suficiente para culminar la fundación de su nueva patria.

\subsubsection{FUNDACIÓN DE SU NUEVA PATRIA}

Como ya hemos dicho, en la novela está reflejada la estructura funcional que organizaba a una sociedad tripartita: oratores, bellatores y laboratores. Trifuncionalidad que, según Georges Duby, sirve como marco de la distribución ideal de los hombres y como instrumento de clasificación que se emplea para celebrar a tal jefe guerrero o tal 
soberano $_{101}$.

Siguiendo esta clasificación, Eneas y todos los personajes analizados van a pertenecer a la segunda función, sirviendo de modelos a los guerreros medievales.

El narrador nos presenta dos caballeros representantes de cada bando, que cumplen a la perfección con el ideal guerrero, con pequeñas variaciones que les hacen excepcionales en el ejercicio de la guerra. Estos guerreros son: Pallas del bando troyano y Camilla del bando griego, siendo éste un caso especial, que choca con la mentalidad medieval que consagraba el ejercicio de la guerra exclusivamente a los hombres.

Pero, Camila representa, a la vez, el ideal de caballero y el ideal de belleza femenina medieval. En la descripción de la guerrera, el autor enumera a través de los adjetivos las tres características que tenía que tener un caballero: sage, vaillante y courtoise. En este caso, la "courtoisie" se añade a las dos cualidades tradicionalmente presentes en los héroes épicos, como en La chanson de Roland, cuando se describe a Olivier y Roland:

\footnotetext{
Rolland est proz e Olivier est sage.

Ambedui unt merveillus vasselage:

Puis que il sunt as chevals es as armes,

Ja pur murir n'eschiverunt bataille.

Bon sunt li cunte e lur paroles haltes.
}

(V. LXXXVII)

En efecto, al rechazar los trabajos propios de las mujeres, Camila se diferencia de los otros personajes femeninos, llegando a formar parte de los modelos a seguir en el combate por los caballeros medievales, como ejemplo de cualidades guerreras. Camila muere luchando, lo que enfatiza su valor caballeresco y desdibuja su condición de mujer:

\section{(...) Onc d'ovre a feme ne ot cure,}

\section{Ne de filer ne de costure;}




\section{mialz prisoit armes a porter,}

A tornoier et a joster

Ferir d'espee et de lance:

$\mathrm{Ne}$ fu feme de sa vaillance.

(V. 3971-3976)

Junto con el compendio de normas de conducta para el caballero, el autor intercala otro dedicado a la mujer medieval, tomando como ejemplo negativo a Dido, que encarna todas las debilidades de las mujeres, y como excepción de mujer a Camila, representada como un caballero, no por ello dejando de estar presente el ideal femenino medieval en su descripción física. Camila es el personaje dual por excelencia, que representa lo positivo de las mujeres y de los caballeros; la negatividad de la imagen de Dido como mujer enfatiza los valores de caballero que posee Camilla:

De biauté n'ert o li igaus

Nule feme qui fust mortaus;

Lo front ot blanc et bien traitiz,

La greve droite an la vertiz,

Les sorciz noirs et bien dolgiez,

Les ielz rianz et trestoz liez;

Biaus ert li nes, anprés, la face,

Car plus blanche ert que nois ne glace;

Entremellee ert la color

Avenalment o la blanchor;

Mol ot bien faite la bochete,

N'ert gaires granz, mes petitete,

Menu serrees ot les denz

Plus reluisent que nus argenz

(V. 3987-4000) 
Por otra parte, Pallas es otro de los caballeros que representan los ideales de la caballería medieval: un caballero novel que, nombrado por su padre, nos muestra la valentía y la destreza con las armas, desde el inicio de su trayectoria.

En esta tercera etapa, en la que Eneas ya ha culminado su iniciación, subsisten restos de sus actitudes negativas pasadas, expuestas por diferentes personajes. En innumerables ocasiones, aparecen exteriorizados los adjetivos negativos para con la raza troyana y más concretamente su líder Eneas, características que no existen en la obra clásica, en la que sus actos fueron producto de un destino dictado por los dioses, como hemos visto anteriormente. El autor reconstruye de tal manera la historia clásica que la figura de Eneas, en esta parte de la novela, sirve como ejemplo a seguir, como modelo del renacer de caballero medieval.

La crítica más efusiva y más vehemente es la que protagoniza la madre de Lavinia: ésta realza los fallos que, como caballero, Eneas no debería de tener y ve como una deshonra su matrimonio con su hija. Llama la atención que sea la madre de Lavinia la que se pronuncie contra Eneas, debido al papel secundario que tenían las mujeres medievales, pero su protagonismo se ve potenciado por el papel fundamental que revisten las mujeres en la novela, desmarcándose de la literatura anterior. En la estructura familiar, destaca su papel de madre y de esposa; en el ámbito social destacan rasgos ideológicos a través de la crítica hacia Eneas: la homofobia y la xenofobia:

"Lasse", fait el, "malaüree,

Que ma fille sera donee

A un homme d'estrange terre,

Qui toz est essilliez par guerre,

Qui s'enbla par coardise

De la cité, quant al fu prise;

o lui s'an vindrent li coart,

Tuit se traistrent a une part,

De cel vassal firent lor roi.

Don test il roi? Ne sai de coi,

Fors de ne sai quantes nacelles.

Ge li ferai oïr novelles,

Bien tost li cuit movoir tel guerre, 
Qu'il nos an guerpira la terre

Ou il an perdra tost la vie.

(V.3361-3375)

Por otra parte, y haciendo referencia a su modelo clásico, el papel de Amata en la Eneida está mucho más difuminado, contando con menos presencia que en la obra medieval. Personaje secundario que se opone a la unión de su hija con un extranjero, encarna, desde la Eneida, la reticencia atemporal y universal para con la exogamia.

Resulta evidente que el autor medieval utiliza a las mujeres para transmitir los valores caballerescos y las funciones de los caballeros, es en el caso de la madre de Lavinia, como fue en el de la hermana de Dido. En efecto, Anna apoya el romance de su hermana con el troyano por razones defensivas, a sabiendas que al rechazar a los barones de alrededor, Dido ganaba muchos enemigos que le declararían la guerra. Eneas significaba protección para su reino:

De totes parz vos coite guerre;

Toz les barons de cest païs

Avez vos fait voz ennemis,

Car ne deignastes a seignor

Home de tote ceste enor;

(V. 1356-1359)

En el terreno de la guerra, el último personaje que tendrá un papel relevante en la trama narrativa es Turno. Encarna los ideales negativos de un caballero, siempre resaltados al compararse con la figura de Eneas. Caballero dual, con actitudes positivas en la lucha y defensa de sus derechos, sus acciones anteriores se ven empañadas por su actitud ante Pallas, muerto: despojarle de su anillo. La avaricia material causará su muerte en venganza de la muerte del joven Pallas. Tras este episodio, el autor confrontará a Eneas y Turno para dar la victoria al verdadero caballero: Eneas.

Sin embargo, Turno aparece como el doble de Eneas en su primera etapa; injustamente tratado por los dioses ya que envían a Eneas a arrebatarle la tierra y a Lavinia. Pero, Turno no huye y se enfrenta a Eneas desde el primer momento, tratado 
como un caballero noble hasta dicho episodio con Pallas, que evidencia su lado negativo ya que la avaricia, le deshonrará y justificará su muerte a manos de Eneas.

\begin{abstract}
Ne voil a tort rien comancier,
$\mathrm{Ne}$ vos ne m'en devez aidier.

Li roi Latins est anciens,

Molt est vialz hon et de lonc tens

Et ne puet mes tenir son regne;

Sa fille m'a donee a fene

Et sa terre tot ansemant,

Sanz nul autre retenement;

Otroié l'ont tuit li baron;

Il n'a chastel, tor ne donjon

Dont il ne m'a pieça saisi;

An ma garde ai tot recoilli,

Les homages des barons pris
\end{abstract}

Et mes gardes es chastiaus mis.

(V. 4125-4138)

La primera etapa de Turno nos muestra pues un personaje combativo, que defiende a Lavinia a la que considera suya por la palabra de su padre y la salvaguarda de las consecuencias que puede tener si se la llevara Eneas. Entonces, Eneas arrastra sus errores expuestos en dos personajes, la madre de Lavinia y Turno, que recuerdan las acciones negativas del héroe y de las de sus antecesores:

** Reproche de la madre de Lavinia

Se ta fille li vels doner,

Il la prendra molt lïement,

Mais ja si tost n'avra buen vent,

Com il la vos avra guerpie,

Molt l'en ert pou s'il l'a honie.

De lui n'atendre tu ja el,

Il a aillors fait altretel:

Dido la dame de Cartage 
Mar vit onques le suen ostage;

Il fist de li sa volonté;

Quant el l'ot piece sejorné,

Si s'en torna o son navire,

Et el s'ocist a grant martire.

(V.-3302-3314)

** Reproche de Turno:

"Il sont antré an molt mal an;

Plus chier nen achata Paris

Heloine, don't il fu ocis,

Que Eneas fera Lavine;

Tolir la me velt par ravine,

Mes il lo comparra molt chier,

Se vos m'en volez tuit aidier"

(V.4176-4182)

En esta última parte de la novela, que transcurre en Laurente, aparece un cambio en la figura del protagonista que, tras el descenso a los Infiernos, ya posee las cualidades de buen caballero medieval, y lo único que le falta es la conquista de su reino. En esta etapa, Eneas se comporta como un guerrero conquistador y no teme el enfrentamiento y la lucha por su reino, actitud que rompe con su etapa negativa iniciada con su huida de Troya. El reencuentro con su padre en los Infiernos le ha servido para confirmar su deseo de conquista y ver claramente su futuro.

En un primer momento, se presenta a los troyanos como un peuple amateur de guerre, que actúa de la misma forma que actuaron los griegos con ellos y que sin piedad saquean y destruyen ciudades; esta primera imagen negativa de los troyanos nos es transmitida por Turno:

Ce saches tu an fin de voir,

Troïen sont de tel maniere

Que, qui saquialt an l'archaintriere,

Que tot de fors lo chanp lo getent,

De tot an tot dedenz se metent; 
Se les aquiauz an ton païs,

Atant t'an es de tot forsmis.

Un recet ont fait an ta terre

Dom il te movent ja grant guerre,

Ardent et proient et ocient

Et tes homes o aus alient;

Se il lor loist longues errer,

Tot te voldront deseriter.

(V.3830-3842)

Por otra parte, la temática guerrera en Enéas se ilustra a través de elementos contextualizados. Así, como un manual de caballería, Enéas representa la práctica más común de la edad Media: armar caballero (v. 4809-4816). El autor refleja esta práctica en Pallas, uno de los personajes más idóneos para representar el ideal de caballero: algo que por supuesto no pudo incluirse en la Eneida.

En cuanto al protagonista, como buen guerrero, Eneas recibe las armas en el momento que ya ha superado todas las pruebas de caballero. La novela nos hace una descripción de cada una de las armas que recibe de su madre Venus, todas propias de un caballero medieval: yelmo, casco y armadura, y a la vez impregnadas de lo maravilloso medieval y del bestiario:

\section{Li halbert fu tresliz d'argent \\ Menu maillié molt soltilment; \\ Forz ert et mervoilles legier}

(V: 4415-4417)

\section{O lo halberc ot hiaume cler}

D'escorce d'un peisson de mer.

$(\mathrm{V} .4427-4428)$

En esta época, en la que los símbolos son tan destacados, el episodio de la entrega de armas no sólo simboliza el armamento del caballero sino la etapa final de su 
iniciación en la que deberá demostrar que posee el valor y la fuerza suficientes para llegar a ser un buen guerrero medieval. La entrega de armas simboliza también el derecho concedido para gobernar la tierra prometida. Esta idea se funda en la entrega que se le hace al caballero en su nombramiento: "la reconnaissance quasi juridique, ou en tout cas déclarative, publique, d'un droit: celui de gouverner, de régner sur un royaume, de diriger une principauté, d'administrer un domaine ${ }_{102 »}$.

La finalidad de la obra medieval, como compendio de los ideales de caballero, provoca otro cambio importante respecto a su modelo clásico. A diferencia de la Eneida que termina con la muerte de Turno, la novela medieval acaba con la visión de la nueva patria de Eneas. El autor concede más importancia al objetivo de Eneas que al combate final contra Turno: al representar al protagonista consiguiendo sus propósitos, ensalza el ideal de caballero y lo plasma en Eneas que, tras su viaje iniciático, se convierte ahora sí en un modelo de caballero medieval. Comparemos los dos textos al respecto:

Eneida, libro XII, v. 940-952:

"y ya el ruego de Turno comenzaba a ablandar su ánimo cada vez más vacilante,

Cuando aparece a sus ojos en lo alto del hombro del caído el talahí infortunado

Y refulge en su cinto el oro de las bolas que le eran conocidas

Era el talahí del joven Palante, al que Turno logro herir

Y vencido postró en tierra.

Él lo ostentaba por divisa fatal sobre sus hombros.

Cuando Eneas fue hundiendo la mirada en el trofeo,

En aquel memorial de su acerbo aterrador: “¿Y tú, vistiendo los despojos

De aquel a quien yo amaba, te me vas a escapar de las Manos?

Es Palante, Palante el que con esta herida va a inmolarte y se venga en tu sangre de su crimen".

Prorrumpe. Hirviendo en ira le hunde toda la espada en pleno pecho.

El frío de la muerte le relaja los miembros

Y su vida gimiendo huye indignada a lo hondo de las sombras.

102. Flori, J., op. cit., p. 64. 
Enéas, V. 10131-10156:

Eneas ot le mialz d'Itaire,

Une cité comencé a faire,

Bons murs i fist et fort donjon.

Albe mist a sa cite non;

Molt par fu riche, molt fu granz,

Ses anpires dura molt anz.

Longues l'a Eneas tenue,

Puis est an sa main revertue

Tote la terre al roi Latin,

Et quant il rala à a fin,

Ascanïus regna aprés,

Et puis fu si com Anchisés

A Eneas ot aconté

$$
\text { (...) }
$$

Cil firent la cité de Rome,

Que Romulus li anposa

Son nom, que primes li dona.

Al comparar la estructura de los dos textos se realza la siguiente idea, sobre todo presente en la clásica: aunque pierde su tierra, Eneas nunca deja de ser un guerrero a pesar de su actitud derrotista con su salida de Troya, huyendo de los griegos, sin enfrentarse a ellos. En Enéas, al entrar en Cartago, sus rasgos de caballero permanecen interiormente y, será luchando contra la adversidad, enfrentándose a numerosas pruebas, como, se manifestará su formación de caballero, hasta la fundación de su propia ciudad.

Así, poco a poco, y a medida que Eneas va superando pruebas, la imagen negativa que se nos plantea al inicio de la novela ha ido desapareciendo. La visión de héroe ya ha evolucionado por el sufrimiento de los siete años en la travesía por el mar, y el relato de la destrucción de Troya, que hace Eneas en primera persona a Dido, le erige en guerrero aguerrido, así lo expresa Dido, esta vez, en tercera persona, después de escucharle:

"Celui qui a sofert tant mals, 


\section{Ce est li Trö̈ens vasaus,}

Que fortune a a essil mis

Et qui vint ier an cest païs;

Ge cuit qu'il est de halt parage

\section{Et de celestial linage;}

Del tot pert bien qu'il est gentiz,

Et molt par est cortois ses fiz;

De lui tenir ne de beisier

Ne me poi er soir sazier.

$$
\text { (...) }
$$

(V.1281-1294)

Observamos la interpretación de Dido, glosada por adjetivos inspirados por el amor.

Es que también contribuyen las mujeres de la novela medieval a que Eneas conozca el funcionamiento de un reino; de alguna manera son ellas las que indican las cualidades positivas de un caballero a la vez que muetran el ideal de mujer medieval.

El final de la novela coincide con el del viaje iniciático de Eneas que desemboca en su vuelta a los orígenes y en el renacer del héroe, habiéndose formado como buen caballero y superado todas las pruebas impuestas. Su triunfo como guerrero se comprueba en la alegría que muestra al desembarcar en la tierra prometida, que contrasta totalmente con su inquietud ante Cartago: liez fu, que unc n'ot mes tel joie / puis que li sieges vint a Troie (V.3107-3108).

Para concluir, cabe insistir en la modificación del héroe de Enéas que, en última lectura, se va aproximando a la imagen de todo héroe novelesco. Podríamos decir que la evolución del personaje de Eneas, desde la etapa de su iniciación, no es sino el reflejo simbólico de la del género. 


\subsection{EL ROMAN DE TROIE Y SUS MODELOS CLÁSICOS:}

\section{INTRODUCCIÓN}

En este apartado, el análisis se centrará en la temática guerrera en el Roman de Troie, y en sus hipotextos o modelos clásicos. Tal y como hemos señalado anteriormente el propio autor medieval expone el modelo clásico que ha escogido para la realización de su novela. Se trata de las obras de Dares Frigio y Dictis Cretense:

\section{Icist Daire que vos öez}

Fu de Troie norriz e nez;

Dedenz esteit, unc n'en departi ;

Mainte pröece i fist de sei

(V.1281-1290)

Dictis Cretense y Dares Frigio pasan por ser los autores de unas desaparecidas crónicas sobre la guerra de Troya, que fueron halladas en época romana y traducidas posteriormente al latín. Ambas obras pretenden ser testimonios auténticos y fidedignos de la propia guerra de Troya, anteriores, por tanto, a Homero, y escritos por hombres que participaron en la contienda: un soldado del bando griego, cretense, Dictis, y un frigio que sufrió el asedio dentro de las murallas de Troya, Dares Frigio. Uno y otro texto, en consecuencia, adoptan perspectivas distintas - y complementarias- frente a los hechos: el relato de Dictis Cretense es filogriego y escrito desde el campo griego; el de Dares Frigio, filotroyano y escrito dentro del recinto de la ciudad sitiada.

Lo que nos relatan ambas versiones tiene varias características de la épica, de la historiografía y de la novela. Estas novelas contrastan con la obra de Homero, a la que también hace alusión el autor medieval; sin embargo, esta obra tiene un carácter moral frente al carácter histórico y documental de las obras de Dictis Cretense y Dares Frigio, hecho que justifica la elección de estas obras como modelo de Benoît de Sainte-Maure. 
En la novela medieval, el desarrollo épico crea una alianza temática con respecto al género literario anterior: la épica de los cantares de gesta. Este estudio deja constancia de la importancia de estos dos modelos clásicos en el Medievo occidental.

Por otra parte, los relatos de Dictis Cretense y Dares Frigio, y más en especial el de Dares Frigio -que, en cuanto que filotroyano, era heredero de una actitud muy romana, de cuya continuidad se mostraban afanosos los hombres del Medievo- influyeron directa e indirectamente en la literatura de los siglos XII, XIII, XIV y XV. Su influencia en la literatura posterior crea nuevas obras que no renuevan el argumento principal sino que lo adaptan a la época, creando nuevas versiones que sirven a los autores para desarrollar sus técnicas literarias.

El estudio de las dos obras ha dado a conocer que Benoît de Sainte-Maure reutiliza en su novela las dos obras de la siguiente manera: los 30000 versos que la forman, en su mayor parte consisten en una paráfrasis del texto de Dares Frigio, y sólo sus aproximadamente 5000 últimos versos, o poco, más recogen contenido procedente del libro VI de Dictis Cretense".

En esta parte de mi trabajo, voy a realizar un análisis de los cambios que efectúa Benoît de Sainte-Maure con respecto a sus modelos en la temática guerrera, observando lo que suprime y lo que amplifica con respecto a las obras de Dares Frigio y Dictis Cretense.

\subsubsection{CAMBIOS REALIZADOS CON RESPECTO AL MODELO CLÁSICO}

Después de tener en cuenta los dos modelos que influyen al autor medieval y el orden en el que los reutiliza, la primera similitud que descubrimos al analizar las obras clásicas reside en el episodio del vellocino de oro. Ambas obras sitúan el episodio de los argonautas, que será la causa de la guerra de Troya, al inicio de la narración. Sin embargo existen varias diferencias entre ellas: el personaje de Jasón en ambas obras es exaltado por su valor y su coraje, sin embargo, en el episodio de Dares Frigio, se difumina el propósito de Pelias al enviar en busca del vellocino de oro a Jasón y, sin embargo, este episodio ocupa un lugar destacado en la obra de Benoît de Sainte-Maure: 
"Quant ce vit li reis Peleüs

Que Jason montot plus e plus

E que chascun jor s'essauçot

Dotos en fu, poor en ot

Que tant creüst, que tant montast

Que de la terre le jetast

Crient sei que s'il vit longement

Qu'il ne l'en laissera neient ;

Mout a grant dote Peleüs

Que le regne ne li laist plus,

Quar, se il s'en vueut entremetre,

Bien l'en porra del tot hors metre.

Mout ot vers lui le cuer felon

Ne ne faiseit se penser non,

Saveir par cum faite mesure

Porreit ja prendre engin ne cure

(V.741-756)

«Cuando vio el rey Pelias que Jasón era tan bienquisto por todo el pueblo, temió que tramara asechanzas contra él y lo echara de su reino; dice a Jasón que en poder de los Colchos estaba el vellocino de oro de un carnero, recompensa digna de su valor; promete equiparle con todo lo necesario para que la trajera de allí103.»

Así, en la fuente clásica el rey no le promete su reino si consigue el vellocino de oro, sino que es un argumento para echar de su dominio a un posible rival. La astucia del rey Pelias está en la obra clásica mucho menos desarrollada que en la medieval. El pasaje de los argonautas aparece como un simple episodio para justificar de manera racional la guerra de Troya. En ambas obras se omite cualquier relación mitológica del vellocino de oro, y Benoît de Sainte-Maure amplifica el suceso desarrollando el episodio de Pelias y Jasón de una manera legítima, y bajo la perspectiva medieval del 
buen caballero que destaca por su valor y que busca superar nuevos retos.

Otro de los cambios que realiza Benoît de Sainte-Maure, reside en el valor que otorga al personaje femenino de Medea. En la fuente clásica su figura queda difuminada ya que es omitida totalmente por Dares Frigio, y Jasón ocupa la mayor parte de la trama. En la obra medieval, se aprecia el cambio de mentalidad que se opera con respecto a la mujer, como en novelas de la misma época como Enéas: Medea, en el texto medieval, es el personaje clave en la conquista del vellocino, tal y como hemos visto en el primer capítulo de este trabajo 104.

Por ejemplo, el episodio de los argonautas en el modelo clásico no alude a la conquista de Medea y a su intervención, cambios temáticos efectuados por Benoît de Sainte-Maure que ya hemos analizado en el primer apartado de nuestro trabajo:

"El rey Pelias ordenó cargar en la nave las cosas que eran necesarias y animó a Jasón y a los que se disponían a partir con él a que marcharan con fortaleza de ánimo a culminar lo que se habían propuesto. Parecía que dicha empresa daría fama a Grecia y a ellos mimos. Informar sobre los que partieron con Jasón no nos parece que sea de nuestra competencia; no obstante, quienes quieran saber sus nombres, lean los Argonautas $_{105}$."

Al realizar la comparación de este episodio, observamos la brevedad y la ausencia de personajes en el modelo clásico, que se asemeja a la épica medieval. Al analizar la novela medieval, a parte de la ampliación del personaje de Medea destacan las cualidades de Jasón. En efecto, Benoît de Sainte-Maure al ajustar este personaje a su mentalidad, le convierte en un nuevo caballero medieval, eliminando el aura mitológica que lo podía alejar de la Edad Media, a favor de una humanización con actitudes tan propias del género novelesco, como son el enamoramiento y la traición, acciones propias de la raza humana, que propiciaban la identificación del lector con el personaje.

El texto clásico relata la consulta de los Argonautas, donde se desarrolla el episodio por completo: se decanta por el carácter documental e historiográfico más que por el carácter literario, lo más importante es relatar las causas de la guerra y sus

104. p. 21-41.

105. Ibid., p. 392. 
consecuencias.

Por otra parte, la función de este episodio para Dares es la de justificar de forma racional la conquista de Troya y su destrucción. La guerra contra Troya se origina con el desprecio que sufren Jasón y Hércules a su llegada a Frigia, antes de la conquista del vellocino; este hecho provoca una serie de enfrentamientos que traerán consigo el rapto de Hesíone y su posterior petición:

“Una vez que llegó a Frigia Jasón, acercó la nave al puerto del Simois, al punto todos salieron de la nave a tierra. Al rey Laomedonte se le anunció que una nave portentosa había entrado en el puerto del Simois y que habían venido en ella muchos hombres de Grecia. Cuando el rey Laomedonte lo oyó, se asustó; consideró que sería un peligro público si los griegos tomaban por costumbre arribar con las naves a sus costas. Envía entonces mensajeros al puerto para decir que se alejen los griegos de sus tierras, y que, si no obedecían su orden, él los echaría de allí con las armas. Jasón y quienes habían venido con él llevaron a mal la crueldad de Laomedonte de ser tratados así por él, no habiendo cometido ellos ninguna injusticia ${ }_{106 . "}$

Esta ofensa es la que desembocará en la guerra que destruirá Troya, y es la actitud de Hércules, la que provoca la primera batalla del conflicto:

"Hércules llevó a mal el haber sido tratado injuriosamente por el rey Laomedonte, él y los que como él habían marchado a Colcos con Jasón; viene a Esparta a entrevistarse con Cástor y Pólux, y hace con ellos un trato para que castiguen con él las injuria recibidas, y Laomedonte no lleve impunemente el haberlos apartado a aquéllos de su tierra y de u puerto: tendrían muchos colaboradores- decía- si se disponían a ello. Cástor y Pólux prometieron que harían todo lo que Hércules quisiera."

"Hércules había marchado contra Ilio y comenzó su ataque contra los desprevenidos habitantes de la ciudad. Cuando se le anunció a Laomedonte que Ilio estaba siendo atacada por los enemigos, al punto se da la vuelta, y, encontrándose con los griegos en el camino, muere a manos de Hércules. Telamón fue el primero que entró en la fortaleza de Ilio; a él Hércules en pago de su valor le dio como recompensa a Hesíone, hija del rey Laomedonte ${ }_{107 .}$ "

106. Ibid., p. 393.

107. Ibid., p. 394, 395. 
Esto es lo que expone su modelo clásico, sin embargo Benoît de Sainte-Maure realiza las siguientes adaptaciones: en la expedición para obtener el vellocino de oro, se centra en las pruebas que ha de superar Jasón con ayuda de Medea para obtenerlo y minimiza la actitud de Laomedonte con Jasón y sus hombres, que provocará la guerra de Troya:

\section{Damage, ergueil, honte ne tort}

\section{Ne vousimes faire en sa terre \\ Ne n'avions talent de guerre. \\ E s'il en Grece fust venuz, \\ A grant joie fust receüz ; \\ Il n'en fust mie congeez, \\ Anceis i fust mie henorez,}

\section{A maint sera encor retraite \\ Ceste honte qu'il nos a faite,}

A tiels qui mout en pesera :

Ce quit, ja faille n'i avra. »

(V. 1078- 1088)

A pesar de las diferencias que ya presenta la novela medieval con su modelo en este primer episodio, Benoît de Sainte-Maure insiste en la fidelidad a la obra clásica, deseoso de exponer la verdad que ya presenta en el prólogo, con repetidas alusiones a la autenticidad. De esta forma, pretende proporcionar rigor a su obra, al mismo tiempo que potencia su creatividad con sus ampliaciones:

De sa vie ne de son fait

Ne sera plus por mei retrait :

Je ne la truis mie en cest livre,

Ne Daires plus n'en voust escrivre,

Ne Beneeiz pas ne l'alonge 


\section{Ne pas n'i acreistra mençonge.}

Daires n'en fait plus mencïon.

Mais qui or vout oïr chançon

De la plus haute ovre qui seit

Ne qui ja mais oïe seit,

Des plus granz batailles crueus,

(V.2061-2071)

Después de este episodio, la siguiente diferencia que encontramos entre el modelo y la obra medieval es la reconstrucción de Troya, que es totalmente omitida por Dares Frigio. Después de la primera expedición contra Troya, que ambos autores desarrollan, el protagonista es Hércules, quien arrasa la ciudad y le concede a Hesione a Telamon, acción que justificará la guerra de Troya y el rapto de Helena de forma racional. En este episodio totalmente creado por Benoît de Sainte-Maure, y que aparece en una de las miniaturas del manuscrito BN fr 60 analizado en la tercera parte de mi trabajo, se observa el primer anacronismo, dentro de la representación de Troya, que refleja la ciudad medieval ideal, teniendo como modelo literario la ciudad de Cartago; representando todas las clases sociales de la época en la que se desarrolla la novela medieval:

Mout la fist clore de bons murs

De marbre, hauz, espés e durs.

Mout en erent haut li terrier,

Au meinz del trait a un archier.

Aveit granz tors tot environ,

Faites de chauz e de sablon.

De marbre fin e de liois,

Jaunes e verz, indes e blois

En esteient tuit li quarrel

Mout bien entaillié a cisel.

En plusors lués ot fortereces 
O chaaphauz e o brestesches,

\section{Sor granz motes en haut levees,}

De granz fossez avironees.

Tiels mil meisons i ot e plus

A reis, a contes e a dus:

La meinz forz n'eüst pas dotance

De trestot l'enpire de France.

(V. 3005-3022)

Esta ampliación de Benoît de Sainte-Maure, mediante la descripción, sigue la línea de la adaptación de la obra clásica a una mentalidad medieval para que el lector pueda identificarse y situarse en la narración. Este recurso no sólo permite observar cómo se ha transmitido la literatura clásica a la época medieval sino que también es un testimonio literario de la evolución de la mentalidad.

Siguiendo con la investigación de las divergencias entre las obras, una destacable es la relacionada con el Juicio de Paris que aparece en ambas, como causa indirecta del rapto de Helena, debido a la promesa que hace Venus a Paris de entregarle a la mujer más bella si la escoge. Si en la obra clásica, el juicio de Paris aparece más disipado que en la obra medieval, en ambas se hace referencia a un sueño, dato que otorga un tono irreal e ilusorio. Pero, el texto clásico no menciona la manzana de oro, explicitada en el texto medieval, como el objeto simbólico por el que luchan las diosas. Esta lucha se puede interpretar como una batalla entre divinidades que se acercan a los hombres y más concretamente a los caballeros medievales que son los personajes a los que se asocia la capacidad guerrera. Al no omitir la totalidad del Juicio de Paris, Benoît de Sainte-Maure lo adapta a la mentalidad de caballero, otorgándole a Paris el papel de juez que decide el destino de las divinidades; de esta forma, desmitifica a las diosas que se subordinan al mandato de un mortal. Paris se sitúa pues al mismo nivel que las divinidades $\mathrm{y}$, como hombre, da prioridad a la debilidad humana, presente en muchos de los caballeros expuestos en la novela; su elección provocará indirectamente la guerra.

A título ilustrativo, exponemos el pasaje del Juicio de Paris en ambos textos, donde se pueden ver las omisiones y ampliaciones que hemos señalado: 


\section{Historia de la destrucción de Troya de "Dares frigio":}

Alejandro comenzó a animarles a todos para que se preparara una flota y se enviara contra Grecia; él sería el caudillo de tal empresa-decía- si quería su padre; tenía seguridad, en la benevolencia de los dioses, de que, vencidos los enemigos, regresaría de Grecia a la patria tras haber conseguido la gloria; pues a él en el bosque Ida- seguía diciendo-, en ocasión en que iba de caza, en sueños Mercurio le había traído a Juno, Venus y Minerva, con el fin de que juzgara entre ellas sobre su belleza; entonces Venus le había prometido que, si decidía que su rostro era el hermoso, ella le daría como esposa a la mujer a la que en Grecia se la tuviera por la de más hermosa figura; tras haberlo así escuchado-proseguía-, había elegido a Venus como la que más destacaba por su rostro. De ahí las esperanzas de Príamo en que Venus iba a colaborar con Alejandro ${ }_{108}, "$

Troya en Benoît de Sainte-Maure:

Fu davant mei Mercurïon.

Celz treis deuesses m'amena, Juno, Venus e Minerva.

Treis feiz m'apela dreitement,

Puis dist: "Paris a mei entent.

Celz deuesses vienent a tei

Por le jugement d'un otrei :

Une pome lor fu getee.

D'or est massis, tote letree ;

Les letres dient en grezeis

Qu'a la plus bele d'eles treis

Sera la pome quitement.

Entr'eles en a grant content :

Chascune plus bele se fait,

108. Ibid., p. 399. 
Chascune est dreiz, ce dit, aqu'el l'ait.

(V. 3874-3888)

Si ambos autores exponen este episodio como si se tratase de un sueño, en el texto de Dares Frigio se prescinde de la intervención divina, se omiten detalles mitológicos y personajes míticos como Mercurio, el mensajero de los dioses, al que el autor medieval, por su lado, siguiendo la tradición mitológica, con un fin ilustrativo, da presencia delante de Paris, y no "Alejandro".

Otra de las variantes reside en el rapto de Helena. El autor clásico no menciona el templo en el que sucede el encuentro entre Paris y Helena y que favorecerá el enamoramiento de ambos: el templo de Venus; acorde con la representación ovidiana del amor explotada por el autor medieval:

"Pero Helena, la esposa de Menelao, estando Alejandro en la isla de Citera, acordó ir allí. Por lo cual se acercó a la playa. Está junto al mar la ciudad de Helea, donde hay un templo de Diana y Apolo. Allí había decidido Helena hacer un sacrificio. Y cuando a Alejandro se le dio la noticia de que Helena había venido a la orilla del mar, consciente él de su propia belleza, comenzó a pasearse por delante de ella con deseos de verla ${ }_{109} "$

Uno de los episodios destacados que amplía Benoît de Sainte-Maure, siguiendo el modelo clásico de la obra de Dictis Cretense y no el de Dares Frigio, es la conquista de Troya por los griegos, con la construcción del caballo. Este episodio demuestra claramente la elaboración de la nueva versión.

La presencia del caballo de Troya muestra la forma de vencer de los griegos; el engaño culmina con la toma de la ciudad y el final de la novela. Al comparar la obra medieval y la clásica se justifica la elección del autor medieval de la obra de Dictis Cretense para cerrar su novela (V. 25911-25936).

La obra de Dares Frigio omite este episodio, quizás por su ideología troyana, y 109. Ibid., p. 402. 
concluye con la asamblea que convoca Príamo y la traición de algunos de los troyanos que acuerdan entregar la ciudad de Troya a los griegos. Al eliminar el episodio del caballo desaparece la posible carga mitológica restando así importancia a la conquista de la ciudad por los griegos, dándole un matiz negativo ya que no se debe sino gracias a la traición de un grupo de troyanos. Para Dares Frigio, la victoria de los griegos no implica valor y coraje en la batalla sino traición.

"Entonces acordaron todos que se les diera la palabra- y ésta se confirmara con el juramento- de que si entregaban la ciudad a la noche siguiente, mantendrían su compromiso para con Anténor, Ucalegón, Polidamente, Eneas, Dolón y todos sus mayores, así como para sus hijos, esposas, parientes, amigos y allegados, que se habían puesto de acuerdo con ellos (....).

Confirmado este pacto y asegurado por el juramento, Polidamante les invita a que lleven de noche el ejército ante la puerta Escea, en cuya parte exterior estaba esculpida la cabeza de un caballo, pues allí tenían sus guardias por la noche Anténor y Anquises, y abrirían la puerta al ejército de los argivos y les mostrarían una luz: ésta sería la señal para el ataque $_{110 . "}$

Dares Frigio señala a todos los culpables de traición y omite el episodio del caballo por completo, haciendo una mínima alusión a una puerta donde hay una cabeza de caballo esculpida y por la que entrarán los griegos cuando tomen la ciudad en la emboscada. Dictis Cretense y Benoît de Sainte-Maure recrean este episodio de diferente manera. El autor medieval toma como modelo a Dictis Cretense, realizando diferentes cambios a su vez; él mismo en este pasaje reconoce haberle utilizado como modelo en lugar de a Dares Frigio:

\section{Riches chevaliers fu Ditis}

E clers sages e bien apris

E scïentos de grant mémoire.

Contre Daire rescrist l'estoire.

$$
\text { (...) }
$$

Icist Ditis nos fet certeins 
Por veir li quel des citeeins

Porparlerent la traïson, (...)

E coment par seducion

De nuit seisirent Ylion ;

Cum la citez fu enbrasee

$(\ldots)$

Tot ce qu'en conte li autors

Vos conterai sans demorer ;

Des or i fait buen escouter.

(V. 24397-24424)

\section{* Episodio del caballo en Dictis Cretense:}

$\mathrm{Si}$ el autor griego sirve como modelo al autor medieval, veremos ciertas variaciones a la hora de adaptar el episodio. Dictis Cretense proporciona un papel importante a la mitología y así se aleja de lo racional que predomina en la obra de Dares Frigio: el episodio del caballo comienza con la información de un oráculo que se le había revelado a los troyanos hace tiempo sobre el Palladio y la protección que ofrecía a la ciudad de Troya. Este es el primer hecho mitológico presente en este episodio. Tras este hecho, el relato presenta al traidor que provocará la caída de Troya: Antenor y la construcción del caballo para la invasión de Troya con el propósito de darle una ofrenda a Minerva para sustituir el Palladio robado, imagen de Palas:

“Esta Palas era hija del río Tritón ( o, Filodemo, del Palamaon), junto al que había nacido Atenea; criábanse juntas las dos niñas, y las dos eran aficionadas a los ejercicios bélicos; un día se atacaron mutuamente y Atenea hirió gravemente a Palas. Pesarosa Atenea, fabricó una imagen de Palas a la que dio el nombre de Paladio, y tomó ella misma el sobrenombre de Palas $111 ”$. 
Otra de las pinceladas mitológicas aparece en la alusión a la construcción de los muros por parte de Apolo, lo que los hacía impenetrables:

"Así, la obra de los muros, inviolada a lo largo de los tiempos, excelsos monumentos que Neptuno- según decían -y Apolo habían levantado, los destruyeron sin consideración alguna las manos de los ciudadanos-". El pasaje hace referencia a este mito de la rebelión contra Zeus de Apolo y Poseidón y el castigo que le impone éste: "recuerda Aquiles a su madre Tetis haberle oído contar que Hera, Apolo y Poseidón intentaron encadenar a Zeus pero Tetis llamó en su auxilio a uno de los Hecatonquires, Briáreo o Egeón, y ya no se atrevieron los dioses insurrectos a llevar adelante su intento. En Homero mismo se menciona el servicio de Poseidón y Apolo a Laomedonte (Il. VII 452 s., donde ambos construyen las murallas de Troya y, más detalladamente, en XXI 441-457, en donde Poseidón es el que construye las murallas, mientras que Apolo sirve como pastor de los rebaños vacunos de Laomedonte en el Ida, ambos por orden de Zeus y durante un año) pero no su causa y motivación. En ambas versiones Poseidón y Apolo, al servicio de Laomedonte, habían construido las murallas de Troya; pero las habían construido mediante previo contrato en que Laomedonte se obligaba a pagarles un salario $112 "$.

Termina la obra con el regreso de los griegos a su ciudad y las peripecias del viaje por mar. Este episodio no aparece totalmente eliminado en la obra de Benoît de Sainte-Maure (V. 27183-30300).

\section{**Episodio del caballo en Benoît de Sainte-Maure}

En este episodio se ve claramente la posición favorable del autor medieval con el bando troyano, a pesar de que utiliza en esta última parte de su relato la fuente de Dictis Cretense que es partidario del bando griego. Su actitud se ve reflejada en las ampliaciones de ciertos episodios y en la creación de otros, ausentes del modelo clásico. 
El inicio de la conquista de Troya se produce por un oráculo que expone que si el Paladio sale de Troya, habría una enorme destrucción en la ciudad. Este episodio que Dictis relata con toda su carga mítica, en Benoît de Sainte-Maure se recrea con disminución de dicha carga mítica, mezclándose a lo maravilloso y otorgándole al Paladio la característica de reliquia sagrada, ya no mítica, que protegía la ciudad desde su fundación.

En lo que se refiere a la descripción del caballo que servirá de engaño para la entrada en Troya de los griegos, vuelve a omitir las características y solo expone el tamaño, calificándolo de objeto maravilloso, más por las dimensiones que por sus características extraordinarias. También aparece en estos versos la alusión a los muros construidos por Apolo que hemos explicado anteriormente:

Ha! las! cum male l'ont parlee!

Grieu ne firent plus demoree:

Mes la merveille- n'en sai plus-

Qu'ot fete e drecee Epïus,

Sor roes forz e granz e dures

Ont soz leves les feitures,

Les laz e les entravemenz.

Adoncs s'i prist tote la genz.

(V. -25893-25901)

Mes tant ot grant e haut le cors

Que portes n'i valurent rien.

E quant ce virent Trö̈en,

Conseill pristrent que des terrauz

Abatreient les granz murauz,

Les biaus, les granz, que Nepturus

Ot fet, mil anz aveit o plus,

E qu'Apollo ot dedié.

(V. 25916-25923)

El relato de la emboscada es muy similar al de Dictis Cretense, sin embargo concurren claras diferencias con el ideal que apoya Benoît de Sainte-Maure. Existe una 
caracterización positiva en el texto de Benoît de Sainte-Maure a favor de los troyanos y una exaltación de la figura del rey que encarna Príamo. En la siguiente cita, podemos ver las características del ideal de buen rey medieval. El personaje de Príamo sirve a Benoît de Sainte-Maure para exponer el buen comportamiento de un rey que incluso intercede por la causante de la guerra, Helena:

Prianz li reis n'oblie mie Que d'Eleine- dont molt fist bien-

$\mathrm{Ne}$ les priast sor tote rien,

E dit que sor celes del mont

Qui sunt nees e qui nestront

La tient il a la plus senee.

Merveilles la lor a löee,

Merveilles lur dit bien de li :

«A toz, fet il requier e pri

Que ne li faciez deshenor. »

(V.25854-25863)

La ingenuidad de los troyanos queda patente en las múltiples alabanzas que prodigan al caballo, sin saber que será la causa de la destrucción. La carga negativa no sólo está presente en la figura del caballo construido por los griegos sino también en las divinidades clásicas que aparecen. En este fragmento podemos ver cómo Benoît de Sainte-Maure se aleja de la creencia clásica y expresa positivamente "Dieu tout puissant"; en cambio, cuando se trata de algo negativo, expresa claramente el nombre griego del rey del Olimpo:

Ce reconte Ditis e Daire,

Que Pirrus a ocis Priant

Davant l'autiel au deu puissant.

La li fist si le chief voler,

L'auteil fist tot ensanglenter.

Por tant en fu vers lui iriez

Reis Jupiter, li deus prisiez.

(V.26144-26150) 
Otro episodio de guerra que llama la atención por su ausencia en el relato clásico es la aparición del Sagitario. El sagitario es un ser mitológico que, tal y como expone Antonio Ruiz de Elvira, "tiene figura de centauro, ya sea con cuatro patas de caballo y dos brazos y cabeza de hombre, ya con dos patas y cola de caballo y el resto de hombre, pero en todo caso disparando un $\operatorname{arco}_{113} "$

Esta es la descripción del sagitario según la mitología clásica, sin embargo Benoît de Sainte-Maure no nos ofrece muchos detalles de este ser mitológico. En el estudio del manuscrito $\mathrm{BN}$ fr 60 , en el tercer capítulo de este trabajo, trataremos este personaje mítico, caracterizado según la primera descripción que indica Ruiz de Elvira, con cuatro patas de caballo y dos brazos y cabeza de hombre. La representación de este elemento mitológico supone una constancia en lo imaginario de la Edad Media. De esta forma nos lo presenta Benoît de Sainte-Maure que expone sus cualidades para la lucha, más que su aura mitológica:

Des le lombril jus qu'en aval

Ot cors en forme de chaval.

Il nen est riens, se il vousist,

Qui d'innelece l'ateinsist ;

Chief d'ome aveit, braz e senblant,

Mais n'esteient mie avenant ;

Il ne fust ja de dras vestuz.

La chiere aveit de tiel faiçon,

Plus esteit neire de charbon .

Li oill del chef li reluiseient,

Par nuit oscure li ardeient ;

De treis lieues, sans niul mentir,

Le pot hon veeir e choisir.

(V.-12355-12388)

113. Ruiz de Elvira, A., op., cit., p. 559. 
Aparte de dichos cambios en la apariencia del sagitario, Benoît de Sainte-Maure describe con gran minuciosidad las armas que posee en la batalla. La descripción común del sagitario suele destacar unas flechas, sin embargo Benoît de Sainte-Maure amplia esta información:

Tant par aveit la forme eschive,

Soz ciel n'a nule rien qui vive

Qui de lui ne preïst freor.

Un arc portot : n'ert pas d'aubor,

Ainz iert de gluz de cuir boillie,

Soudez par estrange maistrie.

Tant par iert forz, nus ne traisist

Ne par force nel detendist.

Cent saietes de fin acier

Porta en un coutre d'or mer,

D'alerïon bien enpenees.

(V. 12369-12379)

Esta representación mitológica complementa simbólicamente el perfil del caballero medieval, tal y como nos lo ofrece el texto, matizado por la presencia de lo maravilloso. El autor introduce a través de este elemento narrativo un nuevo aspecto: a pesar de su naturaleza mitológica, el Sagitario contribuye a representar un ideal medieval: el del caballero; de ahí que el autor lo conserve, y lo rescate en su obra.

En este sentido, una de las ideas fundamentales que podemos apreciar al término de este estudio es la importancia del texto literario como reflejo de las costumbres. A través del análisis de estas dos obras, nos damos cuenta de su valor como vehículo de transmisión de los ideales sociales de la época: «Comme on le voit, les études sur la chevalerie se sont peu à peu orientées vers le domaine de l'idéologie. Sans délaisser les sources historiques traditionnelles, elles ont de plus en plus utilisé les sources littéraires comme miroir déformant la réalité. Cette déformation même paraît aujourd'hui 
significative, et l'on s'attache à découvrir les motivations conscientes ou inconscientes qui ont poussé les auteurs de ces œuvres à altérer ainsi la réalité qu'ils côtoyaient ${ }_{114}$.

Asimismo, a lo largo del análisis, no sólo de los episodios que tienen relación con la temática guerrera, sino también de los episodios estudiados en el primer capítulo de nuestro trabajo, teniendo como tema principal el amor, nos damos cuenta, al compararlos con sus modelos clásicos, que el autor finalmente da prioridad al lector a la mentalidad de la época en la que escribe la obra; más que el deseo de transmitir fielmente la obra clásica, esta actitud, quizás se deba al poco interés que pudieran suscitar aquellos episodios eliminados, o incluso a la incomprensión que podían causar entre sus lectores.

Por otra parte, y en el caso de Troie, más concretamente, hemos observado cómo el autor al tratar positivamente a la raza troyana, toma posición frente a la temática guerrera decantándose más por el bando troyano que por el bando griego. En Enéas, hemos comprobado el compendio de cánones acerca de la figura del caballero que convierten a la novela en un manual del buen caballero representante de una clase social que está en plena ebullición en la época en la que se realiza la translatio de la obra clásica.

Enéas y Troie nos demuestran los valores morales y sociales de la época, además de mostrarnos un ejemplo de caballero ideal: Eneas, que a través de su viaje iniciático logra convertirse en modelo y representante de la caballería, clase social que surge y se impone en el siglo XII, siglo en el que se realizan las traducciones/ adaptaciones objeto de nuestro estudio. Las variaciones estudiadas reflejan como los autores medievales transforman sus modelos clásicos para dar énfasis a la temática guerrera eliminando todo rastro de la mitología clásica que aparecía en las novelas objeto de la traducción, haciendo posible que historias clásicas encajaran en la mentalidad cristiana medieval. 


\section{ANÁLISIS DEL MANUSCRITO ILUMINADO BN fr 60: REPRESENTACIÓN DEL AMOR Y LA GUERRA A TRAVÉS DE SUS MINIATURAS}




\section{INTRODUCCIÓN}

Esta última parte de mi trabajo pretende realizar el análisis de las miniaturas que aparecen en el manuscrito BN fr 60, más concretamente las que hacen alusión a los dos temas tratados: el amor y la guerra. Este manuscrito, datado del s.XIV y conservado en la BNF de Paris, contiene lo que se han llamado "les romans antiques" (Thèbes, Troie, Enéas), hecho que justifica los lazos de unión entre las tres novelas que poseen una temática muy similar. Esta idea reflejada en la página inicial del Roman de Thèbes de este manuscrito apoya la disertación realizada a lo largo de esta investigación:

"Ci commence li roumans de Tiebes qui fu racine de Troie la grant, ou il a moult de merveilles diverses. Item toute l'istoire de Troie la grant. Comment elle fu II fois destruite par le Grigois et la cause pour quoi ce $\mathrm{fu}$, et les mortalitez qui y furent. Item toute l'istoire de Eneas et d'Ancises qui s'enfuirent apres la destruction de Troie. Et comment leurs oirs plueplerent les regions de deça mer et les granz merveilles qui d'euz issirent $_{115} "$

La elaboración de este examen toma como punto de referencia el análisis expuesto en los artículos de Laurence Harf-Lancner ${ }_{116}$, que me han servido de base para

116. Harf-Lancner, Laurence, «L'élaboration d'un cycle romanesque antique au XIIe siècle et sa mise en images: Le roman de Thèbes, Le roman de Troie et le Roman d'Énéas dans le manuscrit BN français 60 », Le monde du roman grec. Actes du colloque international tenu à l'École normale supérieure, Paris 17-19 décembre 1987, éd. Marie-Françoise Baslez, Philippe Hoffmann et Monique Trédé, Paris, Presses de l'École normale supérieure (Études de littérature ancienne, 4), 1992, p. 291-306, y « Les manuscrits enluminés de l'Énéas: assonances et dissonances du texte et de l'image », L'image au Moyen Âge. Actes du colloque d'Amiens, 19-23 mars 1986, Amiens, Centre d'études médiévales, Université de Picardie (Wodan, 15. Serie 3: Tagungsbände und Sammelschriften, 5), 1992, p. 125-135. 
realizar este estudio y adoptar una nueva línea de investigación con respecto a su punto de apoyo. Para ello, he seleccionado un corpus que sigue la línea temática de mi investigación. Así, el primer examen se centrará en las miniaturas que reflejan la representación del amor y escenas amorosas, y la segunda parte estará dedicada a las miniaturas que reflejen escenas de combates y guerras. Veremos cuáles son las miniaturas más comunes y, por lo tanto, más importantes dentro de la representación de los episodios de las dos novelas, así como a qué hechos o momentos de la historia se otorga más importancia a través de la representación en miniaturas, y cuáles se han omitido completamente a pesar de que en la novela correspondiente ocupan un lugar destacado, analizando no sólo su representación sino las conmutaciones realizadas por el miniaturista.

Antes de pasar al estudio temático, hay que señalar el carácter muy relevante, para la clasificación de las miniaturas, que reviste la observación de las primeras páginas de las novelas citadas, en las que se expone un resumen de cada novela a través de una serie de miniaturas. En estas primeras páginas estudiaremos los episodios narrativos más destacados para el miniaturista, la relación entre el texto y la imagen, así como el papel destacado de la miniatura frente al texto.

Para llevar a cabo esta clasificación vamos a tener en cuenta, además de los artículos de Laurence Harf-Lancner, el libro de François Garnier, Le langage de l'image au Moyen Age $_{117}$, que nos ayuda para la observación detallada de los gestos y las actitudes de los personajes en las miniaturas. Según Garnier: "l’expression langage iconographique recouvre deux réalités dans un sens large, elle s'étend à tous les procédés utilisés par un artiste pour exprimer des sentiments et des idées ou pour illustrer un récit. Chaque élément, chaque forme ayant valeur de signe, le choix des personnages figurés, l'organisation du décor, les artífices de la technique peuvent être considérés comme des manières de dire quelque chose ${ }_{118} \%$. Siguiendo esta idea, analizaremos todas las miniaturas seleccionadas observando los personajes presentes, el decorado y las técnicas utilizadas por el miniaturista.

117. Garnier, F., Le langage de l'image au moyen âge : signification et grammaire des gestes, Tom.1 y Tom. 2, Paris, Le léopard d'or, 1982.

118. Ibid., p.10. 
Por último, realizaré un estudio de ciertas miniaturas pertenecientes al miniaturista Richard de Montbaston que, junto al Maître de Fauvel, serán los encargados de la decoración del manuscrito $\mathrm{BN}$ fr 60 . Estas miniaturas tendrán como temática principal la representación de lo maravilloso que aparece en ciertas escenas de las novelas, deteniéndome así en el reflejo del imaginario medieval tan presente en las miniaturas seleccionadas.

He de precisar que los versos citados para comentar las miniaturas pertenecen a la novela de Benoît de Sainte-Maure y no al manuscrito de las miniaturas; he optado por esta forma de análisis en aras de seguir mi línea de investigación y observar los cambios realizados frente a la novela medieval original y como presentación global del material objeto del análisis he introducido a continuación el corpus numerado de todas las miniaturas estudiadas, relacionadas con el amor y la guerra. 
CORPUS MINIATURAS: EL AMOR Y LA GUERRA 


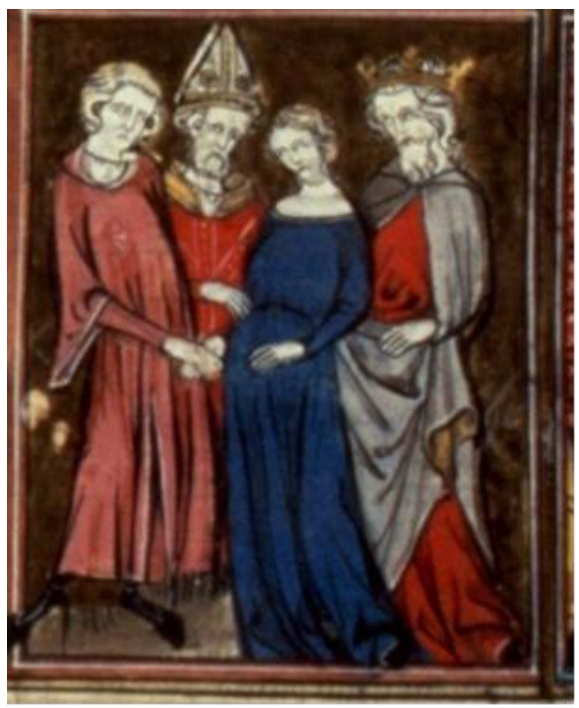

Miniatura 1 (Folio 162)

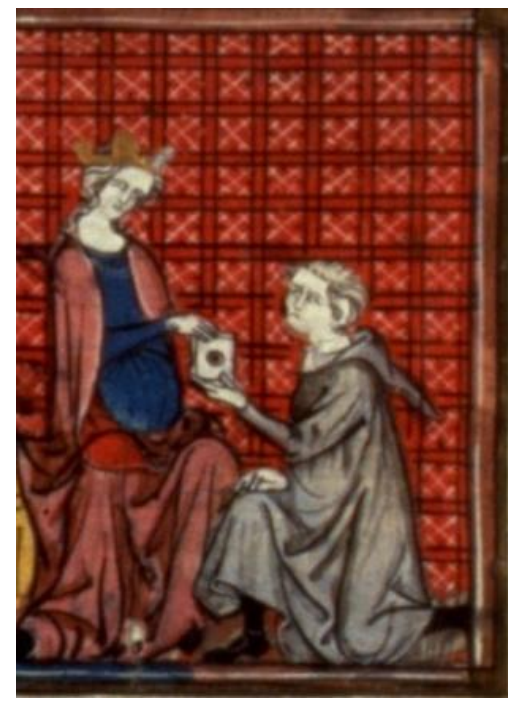

Miniatura 2 (Folio 162)

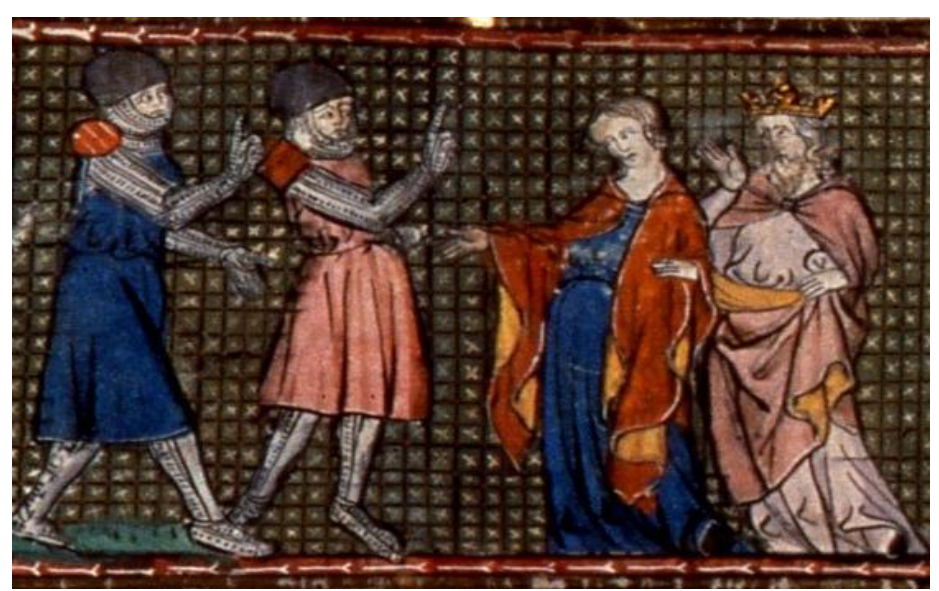

Miniatura 3 (Folio 47) 


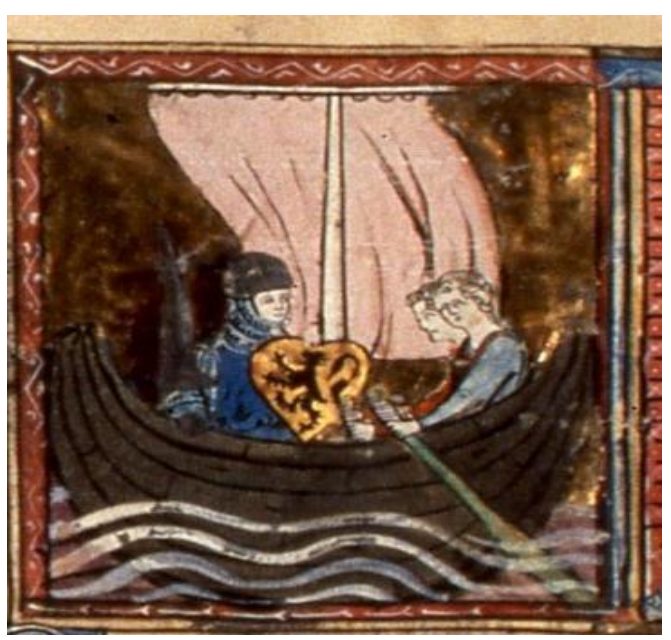

Miniatura 4 (Folio 49)

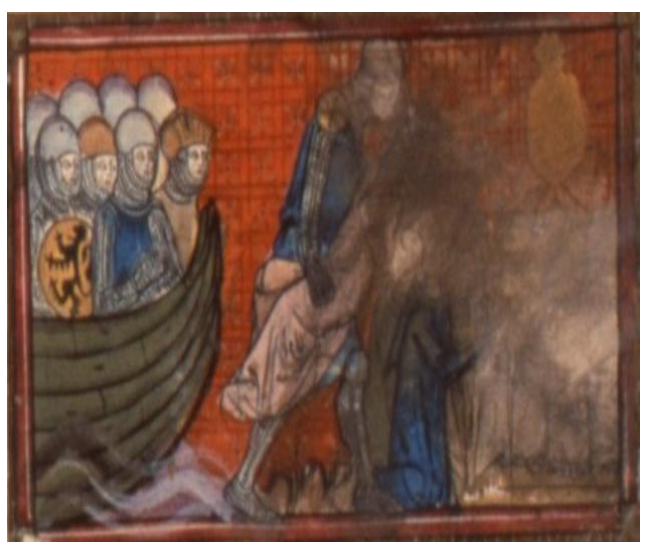

Miniatura 6 (Folio 59)

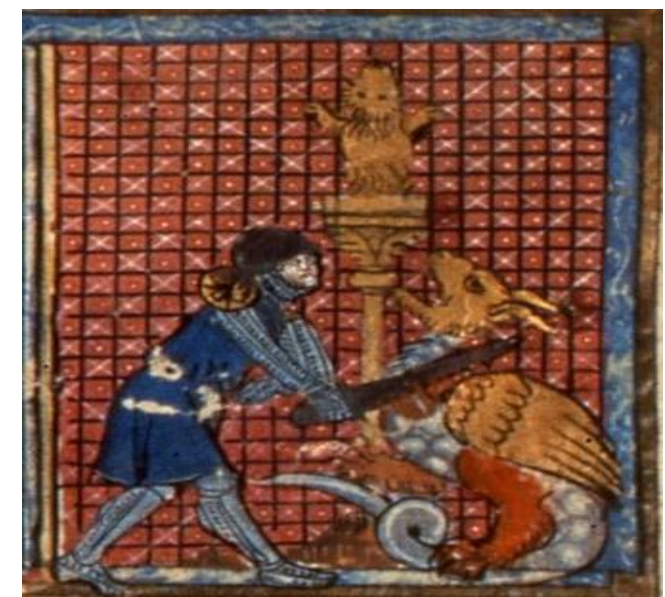

Miniatura 5 (Folio 49)

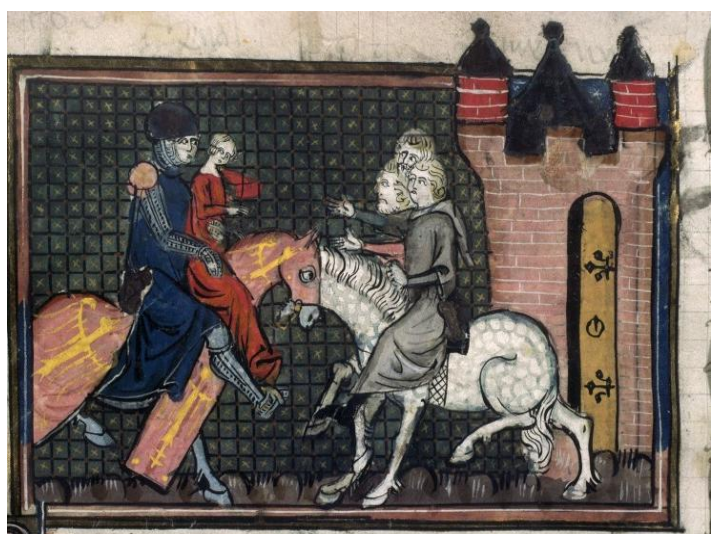

Miniatura 7 (Folio 93)

CORPUS MINIATURAS TEMA GUERRERO ENÉAS

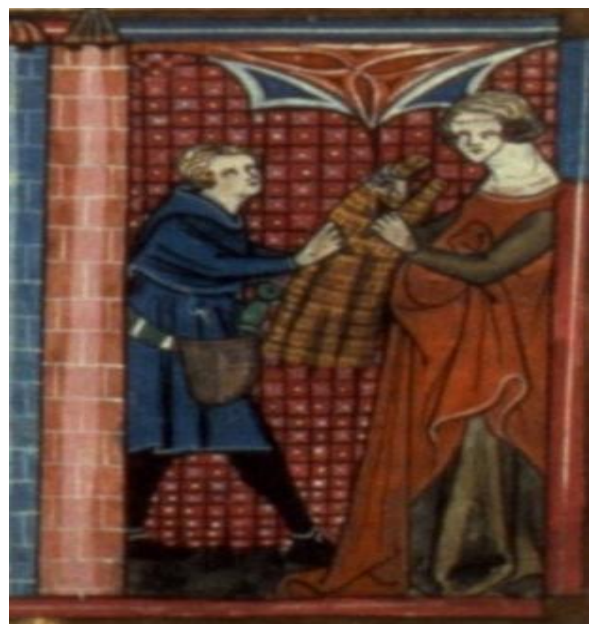

Miniatura 8 (Folio 165)

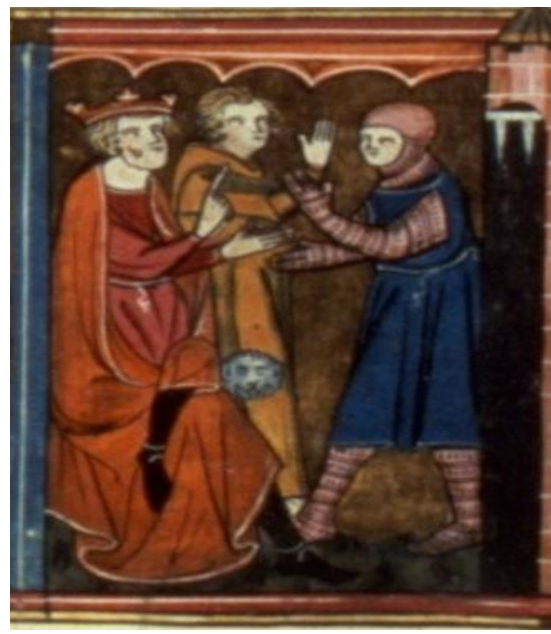

Miniatura 9 (Folio 165) 


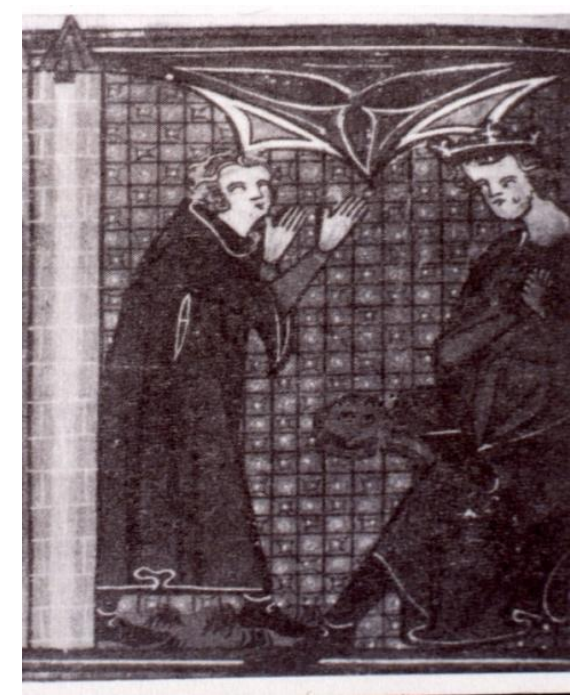

Miniatura 10 (Folio 171)

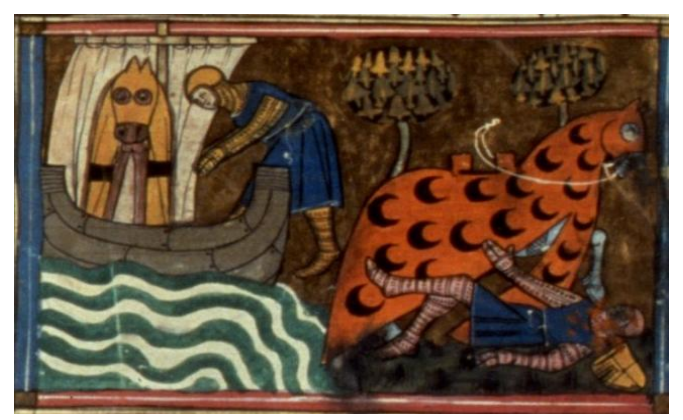

Miniatura 12 (Folio 170)

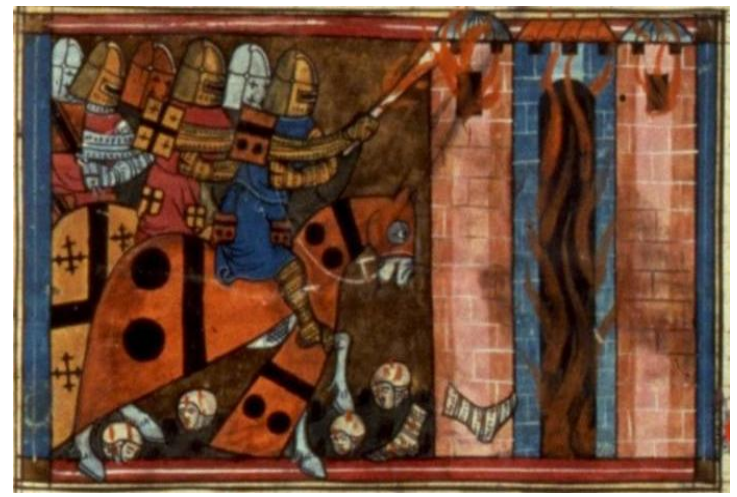

Miniatura 14 (Folio 184)

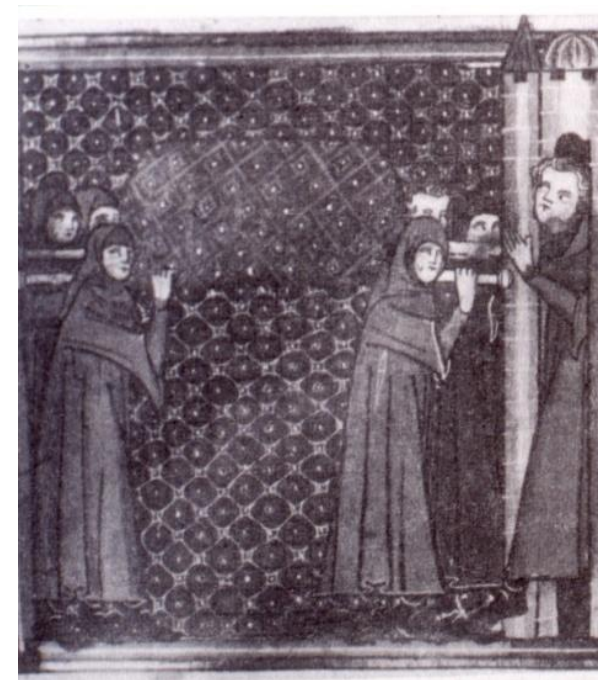

Miniatura 11 (Folio171)

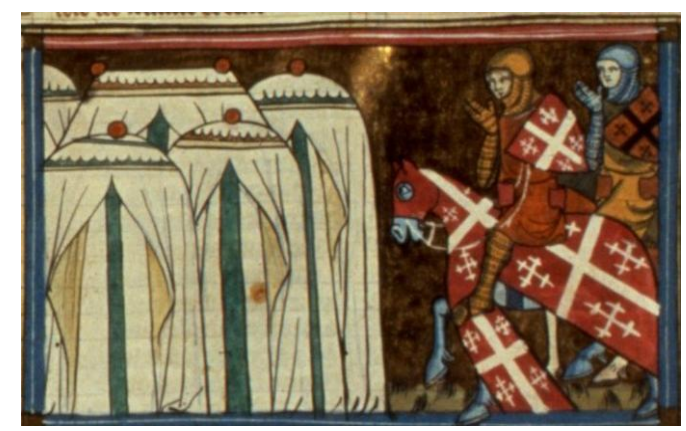

Miniatura 13 (Folio 167)

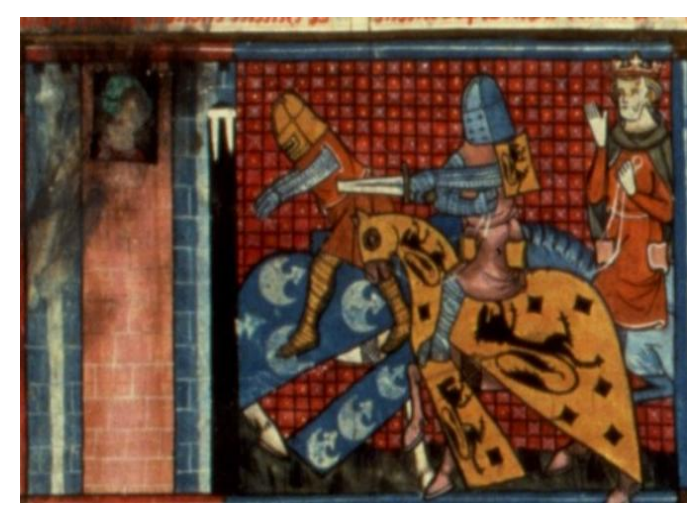

Miniatura 15 (Folio 18) 
CORPUS MINIATURAS TEMA GUERRERO TROYA

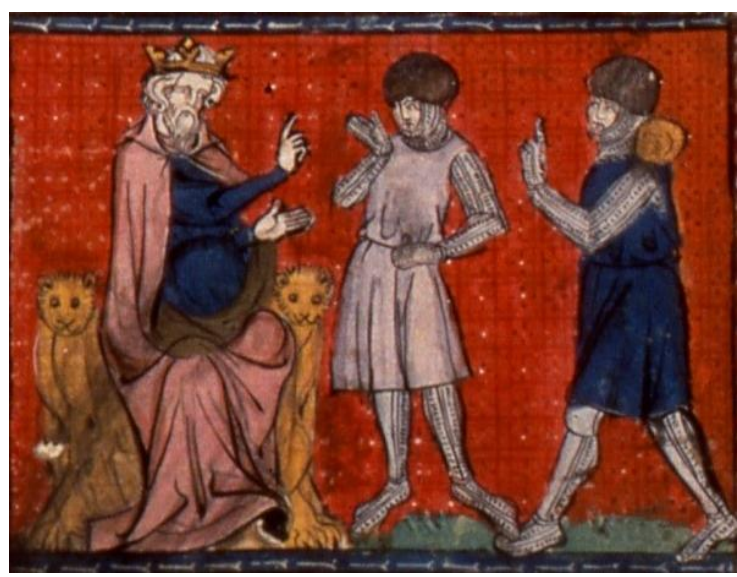

Miniatura 16 (Folio 44)

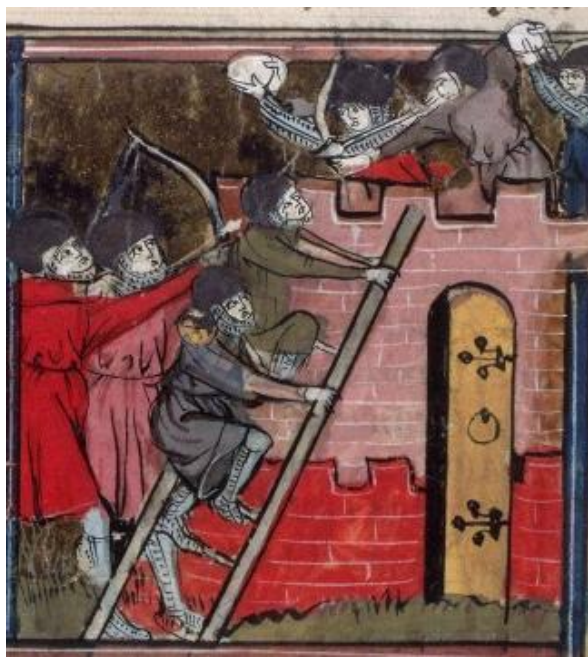

Miniatura 18 (Folio 51)

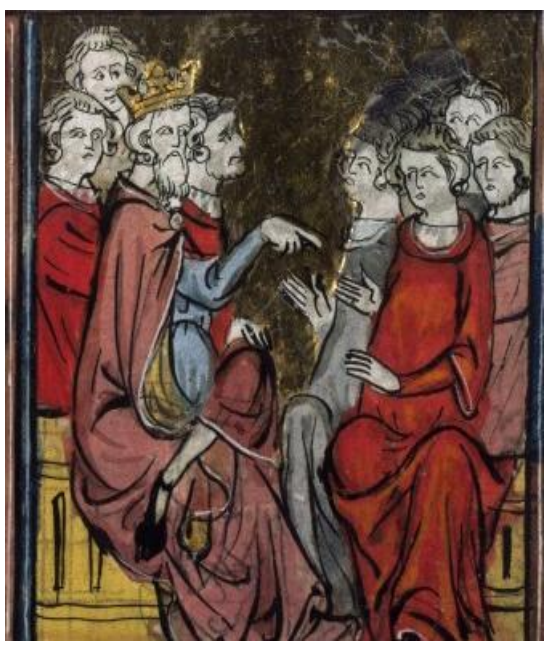

Miniatura 20 (Folio 54)

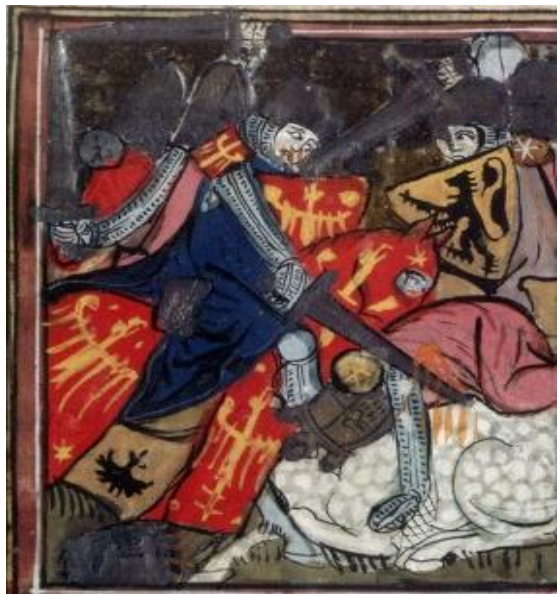

Miniatura 17 (Folio 51)

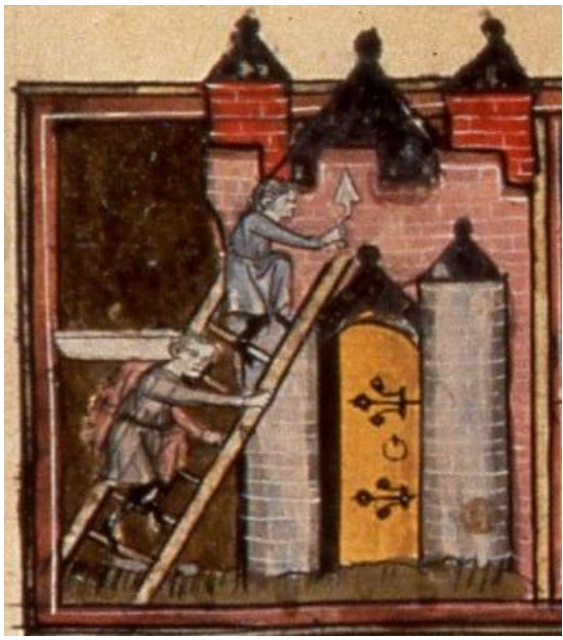

Miniatura 19 (Folio 54)

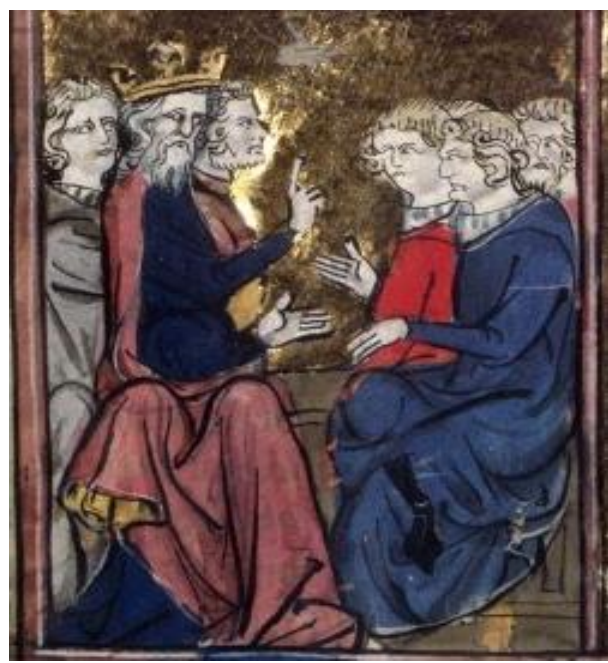

Miniatura 21 (folio 57) 


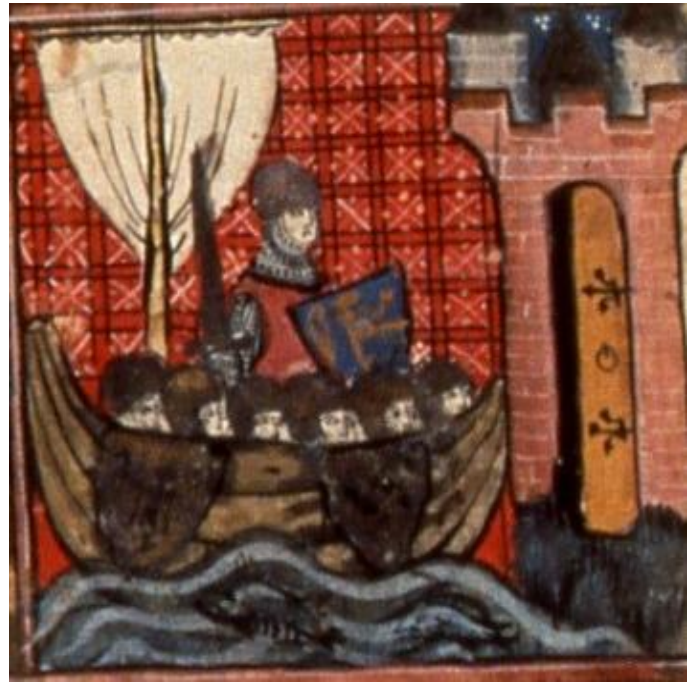

Miniatura 22 (Folio 57)

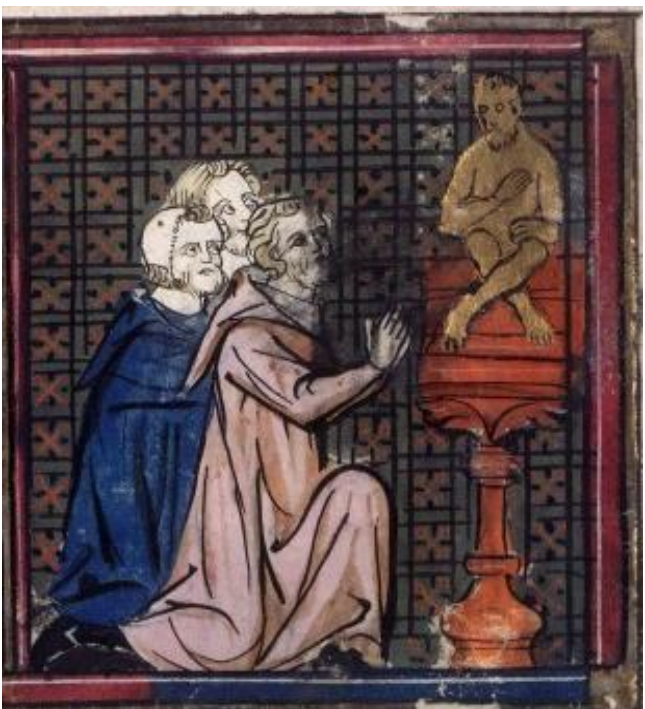

Miniatura 24 (Folio 63)

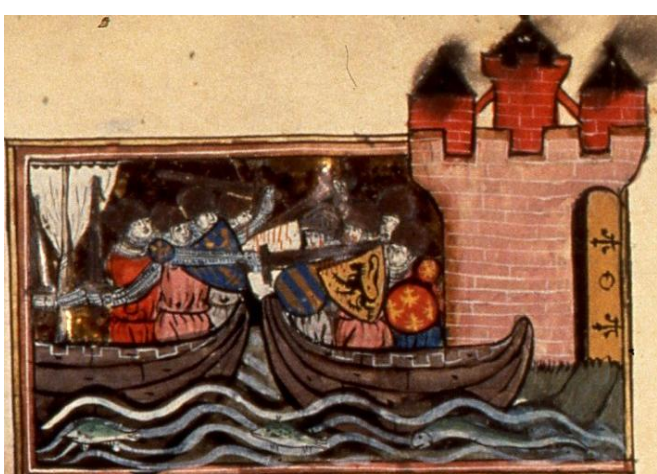

Miniatura 26 (Folio 68)

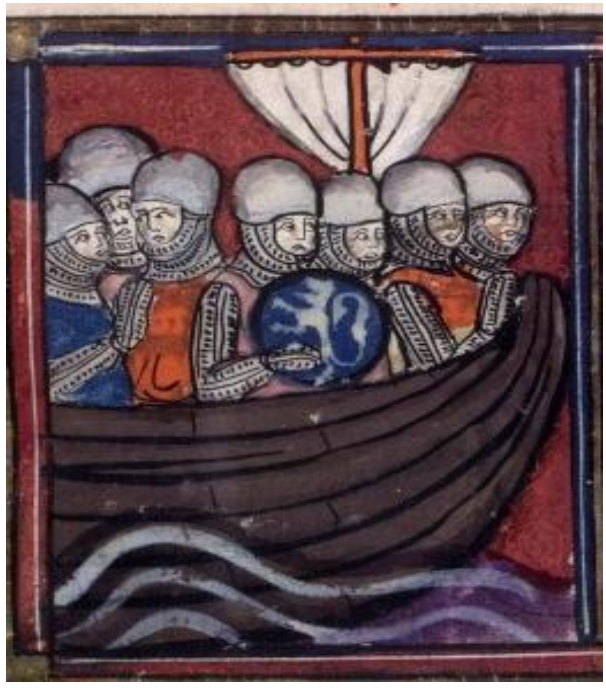

Miniatura 23 (Folio63)

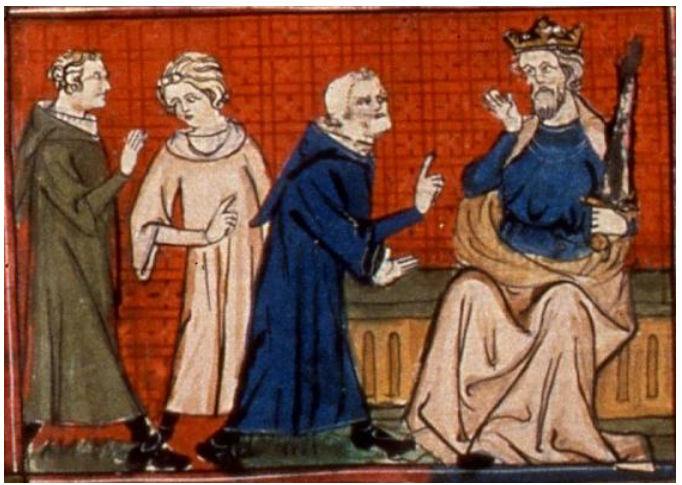

Miniatura 25 (Folio 65)

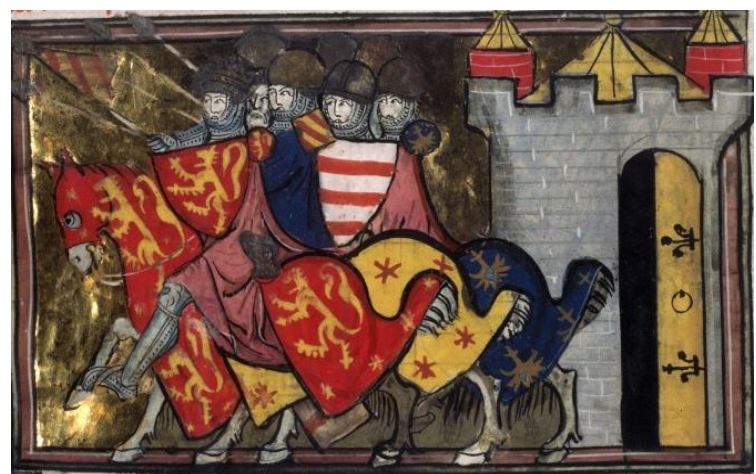

Miniatura 27 (Folio 72) 


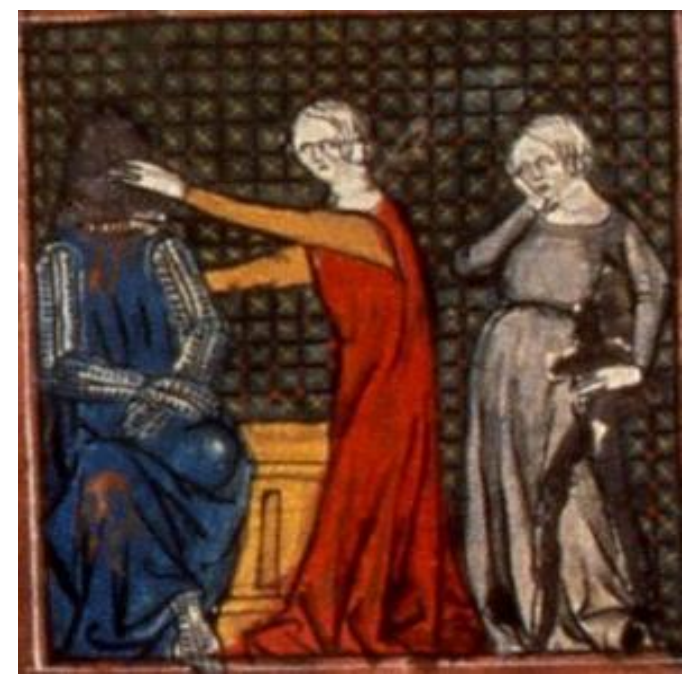

Miniatura 28 (Folio 79)

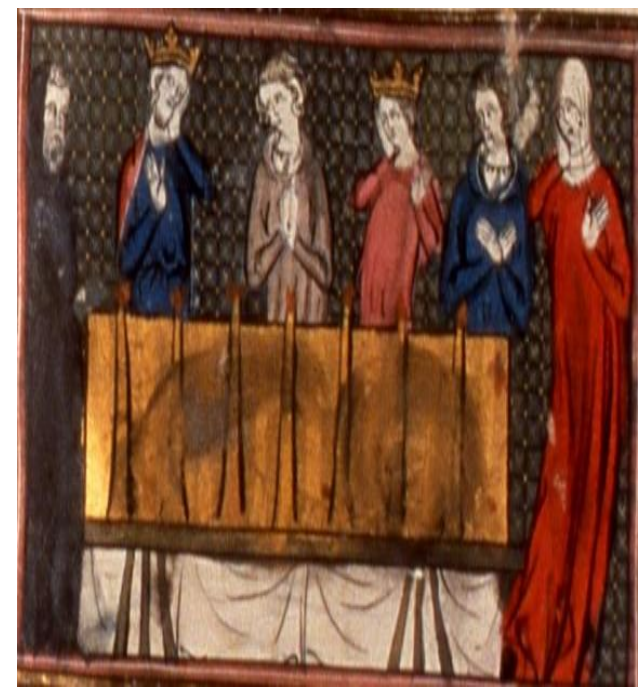

Miniatura 30 (Folio 97)

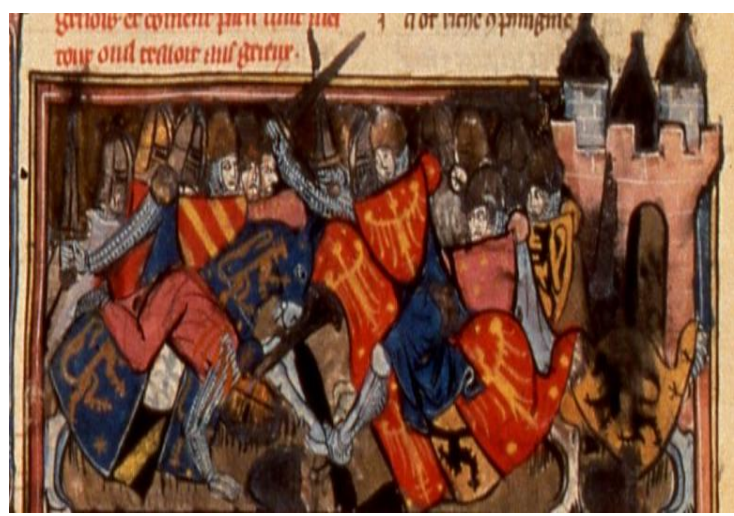

Miniatura 32 (Folio 77)

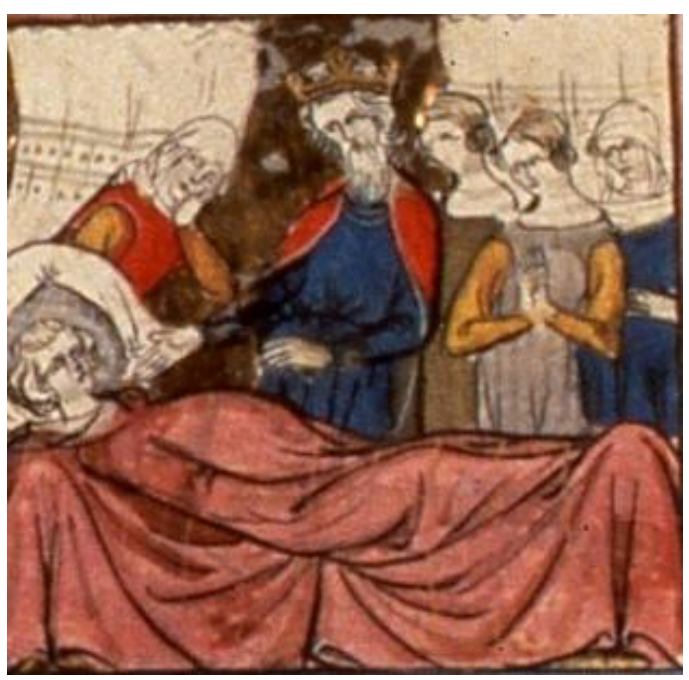

Miniatura 29 (Folio 79)

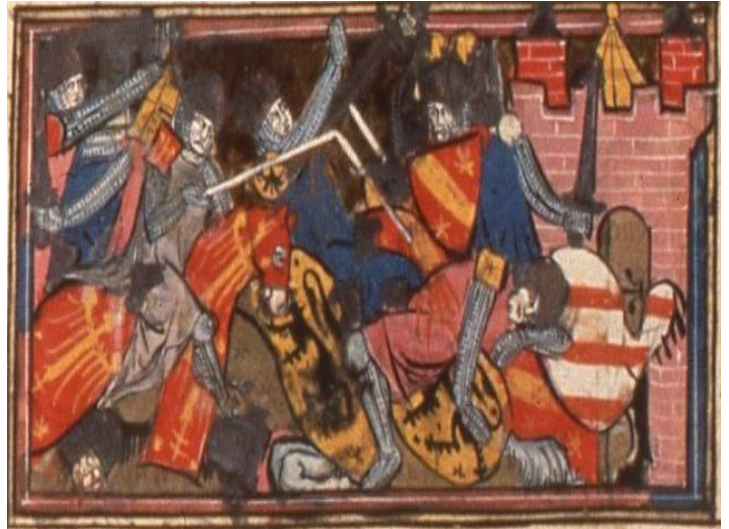

Miniatura 31 (Folio 73)

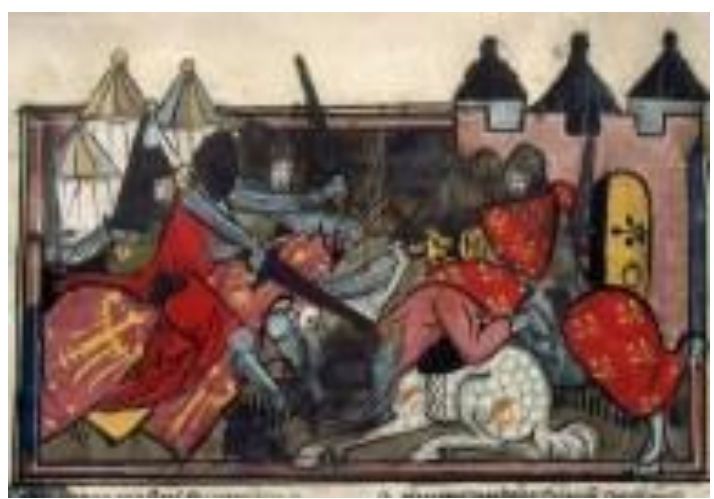

Miniatura 33 (Folio 81) 


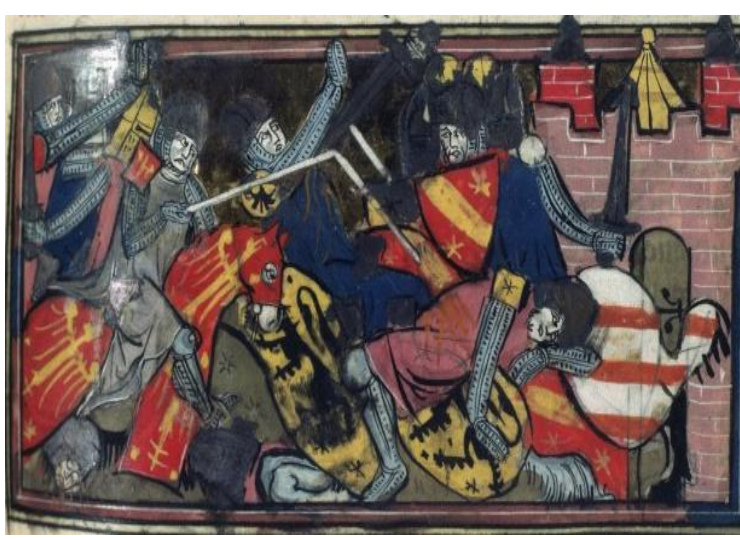

Miniatura 34 (Folio 113)

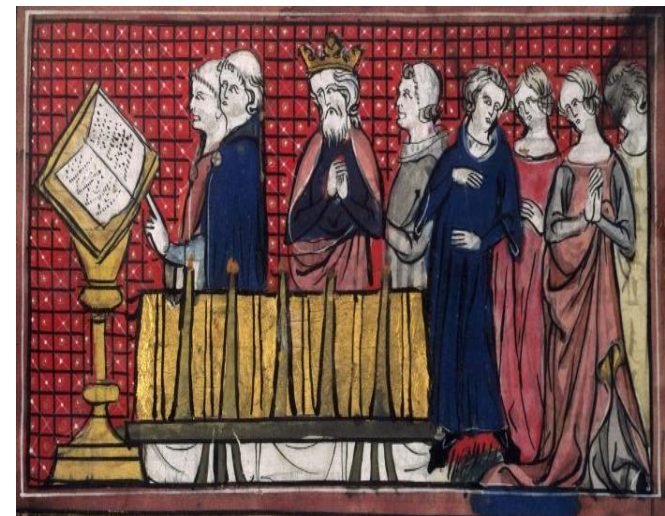

Miniatura 36 (Folio 101)

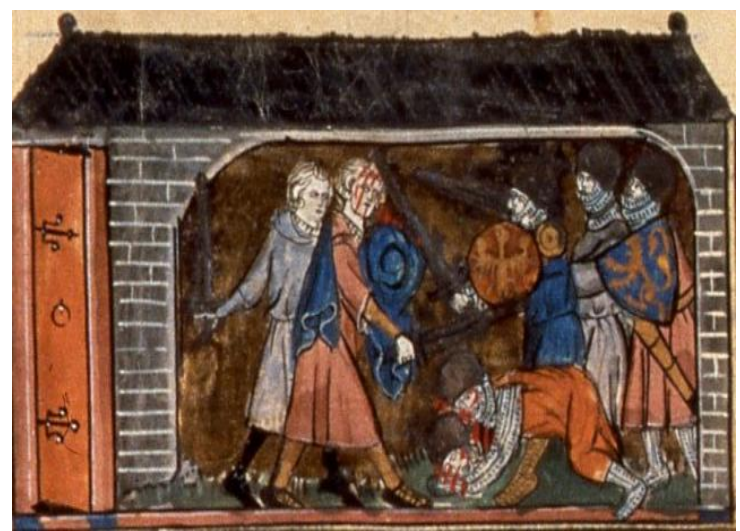

Miniatura 38 (Folio 117)

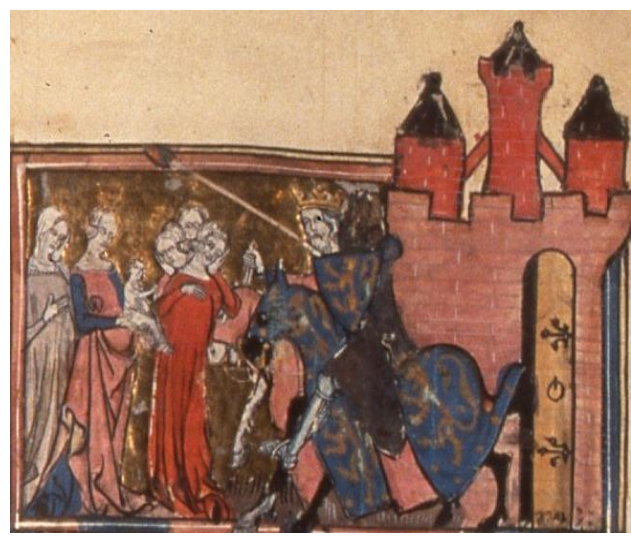

Miniatura 35 (Folio 93)

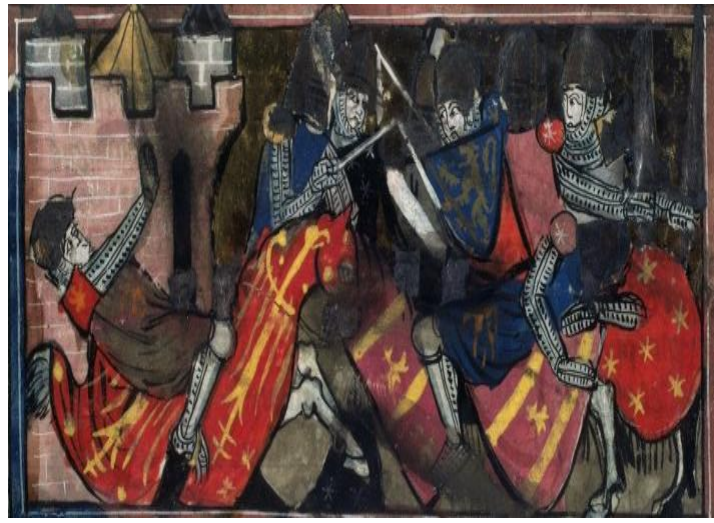

Miniatura 37 (Folio 107)

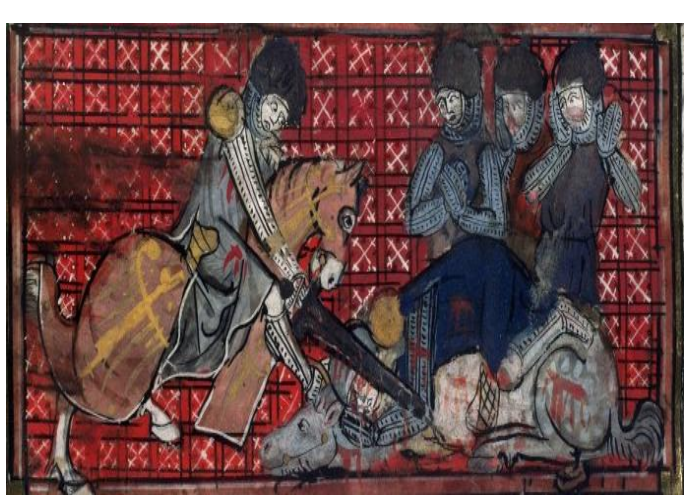

Miniatura 39 (Folio 119) 


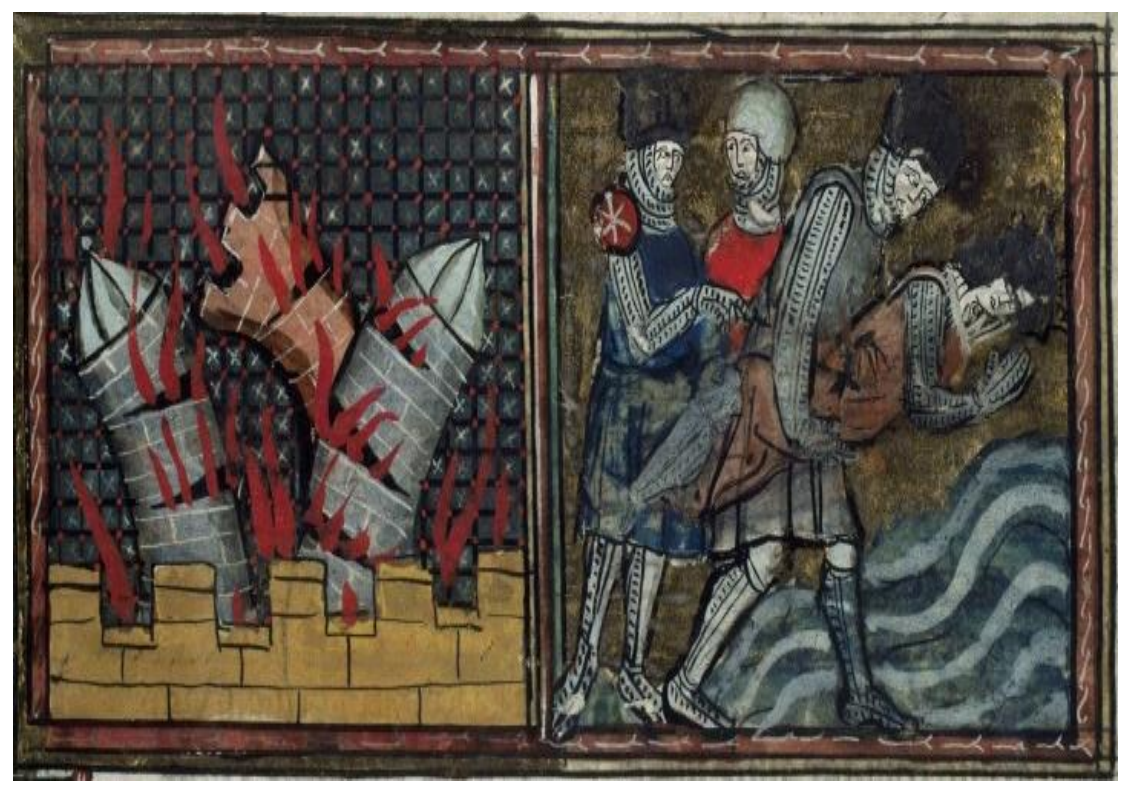

Miniatura 40 (Folio 126)

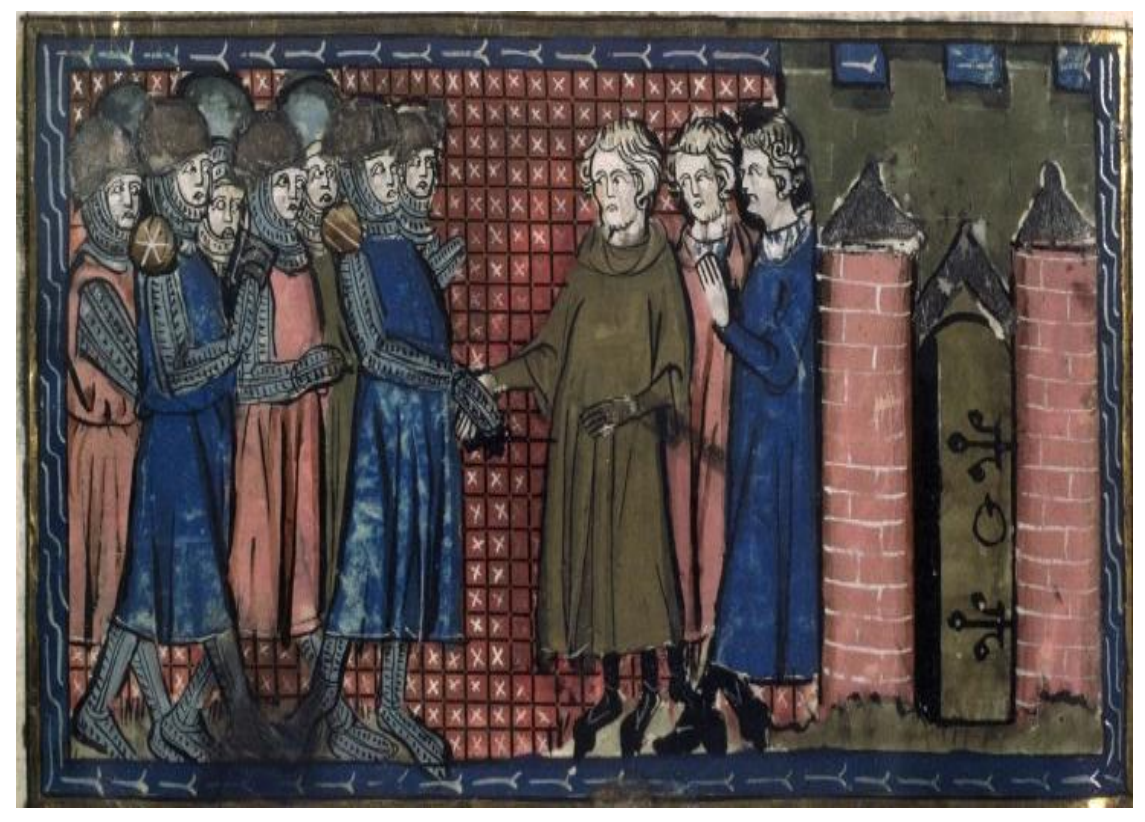

Miniatura 41 (Folio 129) 


\subsection{LA MINIATURA EN FRANCIA}

Antes de emprender el análisis de las miniaturas comenzaremos con una visión general de la importancia del arte de las miniaturas en la Edad Media y más concretamente en Francia, país que va a desempeñar un papel principal en su difusión por toda Europa.

A modo de definición se puede calificar a las miniaturas "comme des motifs, des personnages ou des scènes peintes ou dessinées entièrement à la main sur parchemin ou sur papier, elles constituent une part essentielle des manuscrits importants. L'enluminure a un double but: l'illustration et l'embellissement des textes 119 ».

La importancia de este arte, que tuvo su mayor impulso en el siglo XIV, reside tal y como nos lo expone Smeyers, en su parte indisociable del libro en el que se representa: "La miniature constitue également une source précieuse pour les médiévistes qui n'ont pas l'histoire de l'art comme domaine spécifique de recherche. Principalement par sa dépendance du livre avec lequel il fait généralement un tout, la miniature procure une connaissance approfondie de la civilisation médiévale; elle contribue en effet à structurer les diférentes parties du texte, à mettre l'accent sur l'importance du contenu par le moyen de la décoration, et finalement à visualiser le sens même du texte. Son étude conduit à une connaissance plus exacte des conceptions du temps concernant l'écrit et sa transmission au lecteur 120 ".

Lo que el miniaturista quiere transmitir al lector a través de sus miniaturas tiene una relación muy estrecha con su interpretación personal de la novela; de esta forma, al igual que ha hecho el escritor, aporta su propia perspectiva, dando una nueva versión de los hechos, sin distanciarse de la trama inicial.

119. Smeyers, M., L'art de la miniature flamande : du VII au XVI siècle, trad. de Monique Verboomen, Tournai (Belgique), La renaissance du livre, 1998, p.14.

120. Smeyers, M., Typologie des sources du Moyen âge. La miniature, Brepols, Turnhout, 1974, p. 7. 
Recordemos de paso que el término miniatura deriva de minium, un óxido de plomo de color rojo que se utilizaba como componente fundamental en la primera etapa de su desarrollo para fabricar la tinta con la que se elaboraban las miniaturas. Esta sustancia se empezó a emplear para la iluminación de los códices manuscritos en letras capitales, márgenes y, posteriormente, con la evolución de la ilustración medieval, en representaciones de gran colorido y complejas composiciones. Otra de las características de la miniatura es el soporte en el que se realiza: papel o pergamino.

Las miniaturas que vamos a analizar pertenecen a la pintura franco-gótica que se desarrolla hacia mediados del siglo XII hasta mediados del siglo XIV. Hay que destacar que la pintura gótica implica un gran cambio con respecto a la tradición pictórica anterior, la pintura románica. Podemos dividir la historia de la miniatura en dos grandes fases: la phase hiératique et la phase naturaliste 121.

Los inicios de la miniatura aparecen con Carlomagno y sus sucesores: la miniatura de la época carolingia tiene su primera gran época hacia el final del siglo VIII. Una de las características a destacar son los temas de las miniaturas, que comienzan a ampliarse: no sólo se tratarán temas de origen sagrado sino que aparecen poco a poco temas profanos. Es en esta época, con la dinastía de Carlomagno, cuando surge la primera escuela de miniaturistas, la escuela Palatina de Carlomagno.

Posteriormente, en el reinado de San Luis, el centro de la ilustración de los manuscritos se va a establecer en París. A partir del siglo XII, se deja de lado los temas laicos para tratar de manera más frecuente temas profanos; los scriptoria monásticos dan paso a talleres ubicados en ciudades de Borgoña o Flandes además de París.

La época anterior se caracterizó por la decoración de Biblias, salterios, etc, cuyo distintivo era el fondo de color oro que ha sido interpretado desde el principio como símbolo de luz trascendente, luz irreal sobrenatural tangible por nuestros sentidos ${ }_{122}$.

Por otra parte, en una sociedad de esa época del Medievo, fuertemente jerarquizada y dividida desde el punto de vista social, los tres estamentos -la 
monarquía, la Iglesia y la burguesía- fueron los principales promotores del libro manuscrito iluminado en la Francia medieval. De todos ellos, el principal impulsor fue la monarquía, englobando dentro de este apartado tanto al rey como a todos los miembros de la familia real, así como a los miembros que formaban la corte, nobleza u oficiales de alto rango. La posesión de esta categoría de libros se entendía como objetos de lujo, al ser comprados tan sólo por personas de alto nivel económico.

Aunque donde tendrá más auge es en Francia; no hay que olvidar, como expone Smeyers, que “Tous les pays de l'Europe occidentale sont impliqués dans l'histoire de la miniature, mais ils n'y jouissent pas tous d'une part égale et aussi importante et ils n'y participent pas tous à la même époque. Avant l'an mil, l'art de la miniature se limite à quelques régions bien précises. Passé cette date, il s'étend à l'Europe occidentale entière $_{123} "$.

París fue uno de los centros más importantes de la realización de manuscritos iluminados desde el s. XIV por ser uno de los principales centros universitarios y porque contaba con la tutela de la monarquía y de la corte que rodeaba al rey, principalmente a Carlos V. Tal es la magnitud de la miniatura francesa en esta época que "grâce au mécénat des Valois, l'illustration parisienne du livre parviendra, au XIV siècle à une maîtrise incontestable. Depuis la fin du XIV siècle, principalement sous les règnes de Charles V et Charles VI, les cours françaises attirent des artistes étrangers. La présence de ces derniers influencera d'ailleurs profondément la miniature française 124 ".

Con el Renacimiento, la etapa notoria de la miniatura va poco a poco perdiéndose por el libro impreso y el nacimiento de la imprenta. Los años de oro de la miniatura en la decoración de los manuscritos, tanto de carácter laico como profano, dejan paso a una nueva época, donde se desarrollan nuevas técnicas pictóricas. El manuscrito queda relegado a un segundo plano sin que la importancia de su estudio haya decrecido a lo largo de los años, ya que su valiosa información sobre la época en la que se realiza nos refleja las costumbres y la manera de pensar en la Edad Media.

123. Smeyers, M., op. cit., p. 21.

124. Ibid., p. 26. 
De este modo, el examen de las miniaturas es significativo dado que las ilustraciones ayudaban a la comprensión del texto y reflejaban las escenas más destacadas de lo escrito, por eso las miniaturas debían aportar algo más que pura decoración, siendo su función principal hacer el texto más comprensible: "Eran extremadamente importantes en la época medieval debido al escaso nivel cultural de la población, lo que provocaba que su acceso estaba muy restringido. Por tratarse de una inspiración visionaria, la imagen no es una muleta, sino la forma original del edificio intelectual; la pintura es el intento de hacer accesible a la percepción sensorial lo que ha visto el ojo interno $125 "$

A pesar de su sencillez las miniaturas daban una nota de color y variedad además de una lección comprensible para toda clase de público. Tal y como expone Smeyers:"La décoration est en elle-même le support d'une leçon qui se dégage du texte écrit. L'illustration et la décoration contribuent toutes deux à souligner la structure interne du manuscrit ${ }_{126}{ }^{\gg}$.

Al observar las miniaturas de tema guerrero nos damos cuenta de que los anacronismos presentes en la novela medieval se conservan también en su ilustración, con el fin de acercar los hechos clásicos a los lectores medievales: "les illustrations étaient en outre aptes à donner au passé une réalité présente. Richard de Fournival (1201 avant 1260) note: «lorsque quelqu'un regarde une estoire de Troie ou d'un autre événement, il voit les actes des morts comme s'ils étaient vivants ». Le spectateur a le sentiment d'être présent sur les lieux de l'événement représenté. (...) L'image permet de visualiser ce qui ne peut être vu parce que les faits appartiennent au passé ou ont lieu dans une région éloignée. Et en même temps, elle actualise les événements pour le spectateur $_{127 "}$.

En este sentido, el examen de este manuscrito que contiene los "romans antiques" de Thèbes, Troie y Enéas apoya la idea ya mencionada de la cohesión entre las tres novelas, y también, por las ilustraciones que acompañan estas novelas, la elección de mis temas de análisis (el amor y la guerra, y las representaciones 
mitológicas). Asimismo, podremos observar explícitamente los nexos de unión temática expuestos a través de las miniaturas que decoran este manuscrito. Quiero precisar que mi examen se centrará únicamente en Enéas y Troie, aportando así el punto y final a este trabajo de investigación dedicado a los dos grandes temas de las adaptaciones medievales latinas, que no son sino nexos entre sí de los tres "romans antiques".

Para cerrar este apartado expongo a continuación una selección de tres miniaturas de cada uno de los principales autores de las diferentes escuelas, correspondiendo a sus obras más importantes y conocidas, como parte destacada de la miniatura francesa, que resumen el carácter notorio y la evolución del arte de la miniatura en Francia en la época medieval, así como su gran importancia, no sólo como ornamentación del libro en el que se presentaba, sino "como punto de convergencia entre escritura, decoración e ilustración, que fue, dentro de ciertos límites, un vehículo vivaz y móvil de ideas. Su facilidad de transporte contribuyó a la difusión de la cultura y el gusto $128 "$. 

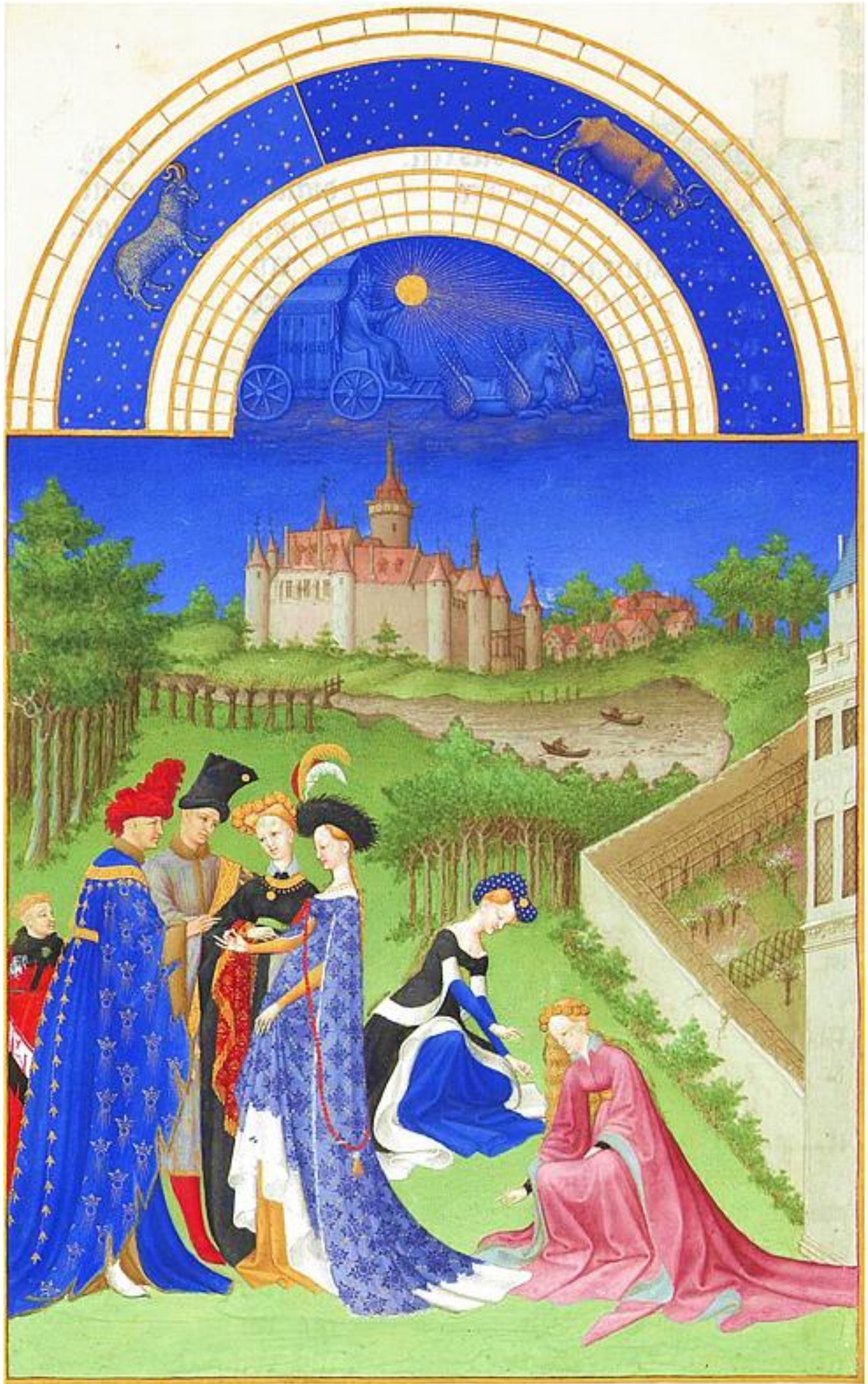

Les Très Riches Heures du Duc de Berry. Hermanos Limbourg. 


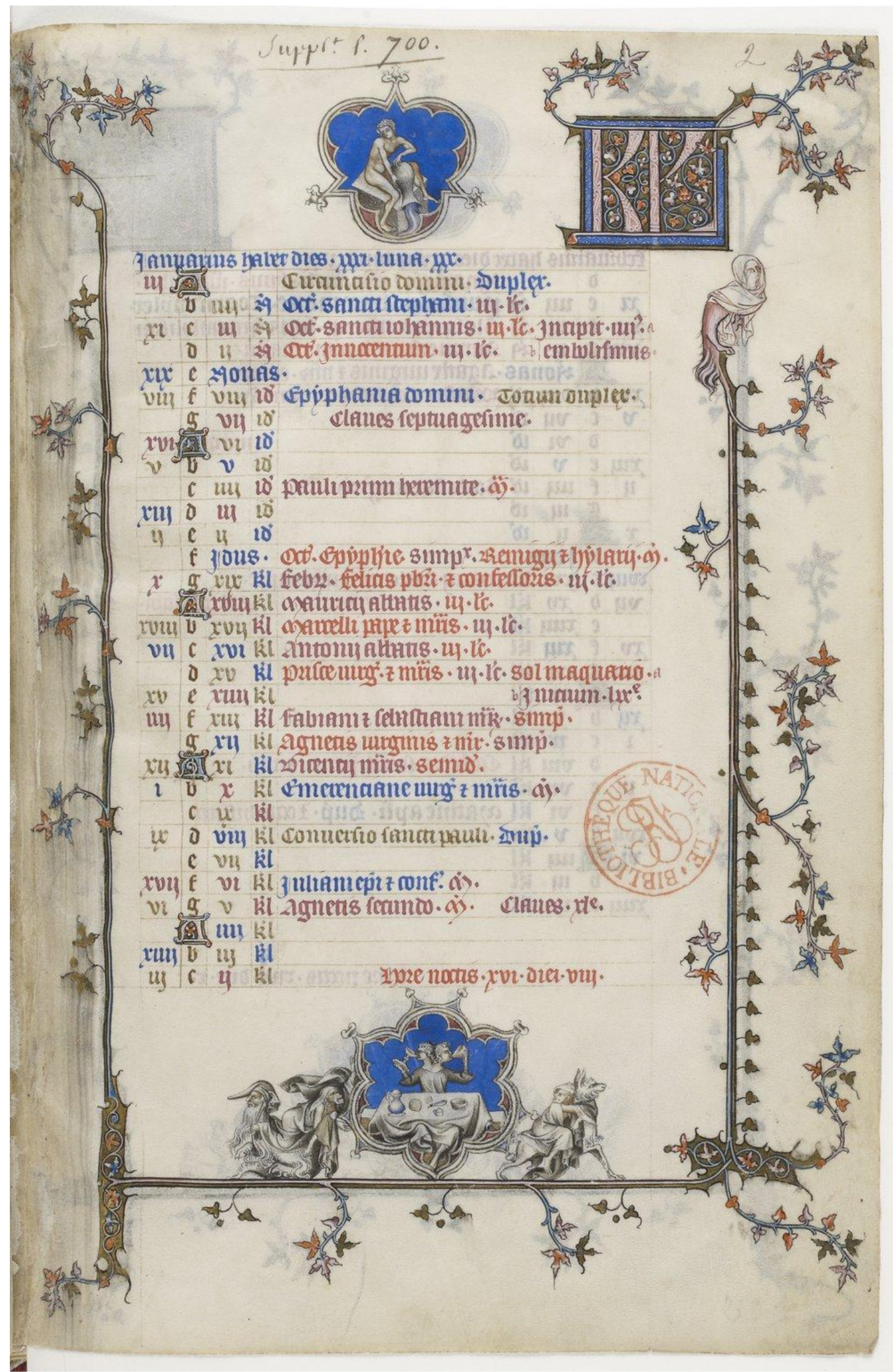

Source gallica.bnf.fr / Bibliothèque nationale de France

Bréviaire de Belleville. Jean Pucelle. 


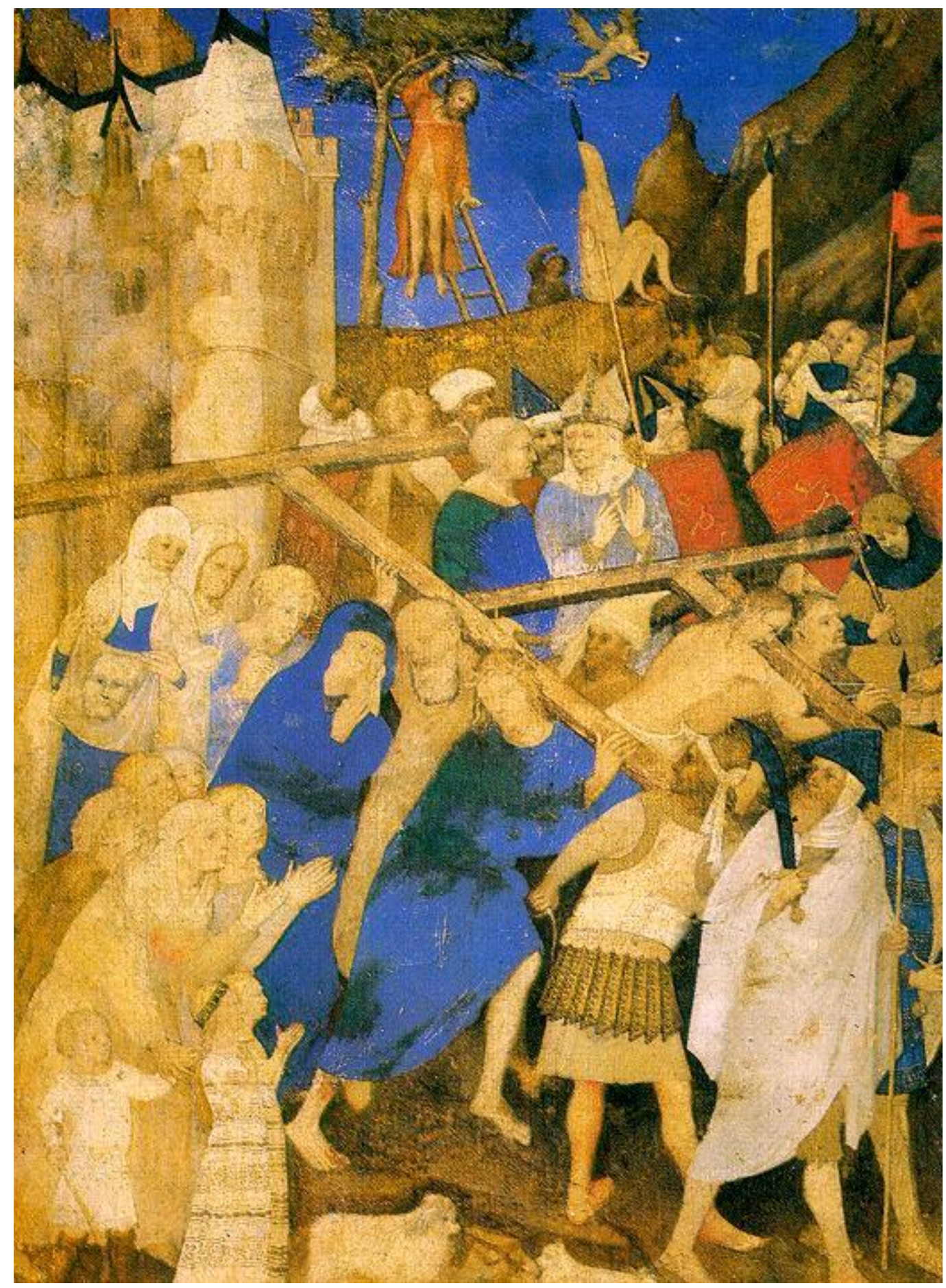

Portement de croix. Jacquemart de Hesdin. 


\subsection{LAS MINIATURAS INICIALES DE ENÉAS Y TROIE}

Tras la anterior reseña sobre la miniatura en Francia y su evolución, pasamos al estudio de las miniaturas correspondientes a Enéas y Troie, presentando antes el manuscrito iluminado de la BN fr 60 que fue elaborado en Ile-de-France en el siglo XIV. Es un manuscrito que perteneció a Estienne Tabourot, dato comprobado por su firma en la parte inferior de la primera página. Este manuscrito está compuesto de tres páginas iniciales que corresponden a cada una de las novelas que contiene y ocupan enteramente la página, dividida a su vez en varias miniaturas que reflejan diferentes hechos destacados de las tres novelas. Este manuscrito, como nos dice Harf- Lancner, «c'est un exemplaire de luxe, qui au XVIe siècle a appartenu à Estienne Tabourot sire des Accords. (...) Dans ce manuscrit (comme dans les autres), l'image (comme le texte) traduit le monde antique en termes contemporains (ce qui est le propre des bonnes traductions). Les héros grecs évoluent donc dans un univers médiéval ${ }_{129}$ "'.Es que, a pesar de datarse tres siglos después de la realización de las traducciones/adaptaciones de la época del Roman Antique, el manuscrito continúa representando el anacronismo, siendo los personajes y los espacios totalmente diferentes a los expuestos en las fuentes clásicas.

Por otra parte, y tal y como expone Jung, «les trois textes du manuscrit sont illustrés par des miniatures, qui semblent être en partie du "maître du Roman de Fauvel" et de son atelier, à la mode entre 1315 et 1340 130». El miniaturista debe su nombre a la novela de Fauvel que lo hizo muy famoso, siendo un artista muy activo a principios de siglo XIV. Tal y como podemos apreciar en esta obra, las miniaturas son muy

\footnotetext{
129. Harf-Lancner, L, « Les manuscrits enluminés de l'Énéas: assonances et dissonances du texte et de l'image », L'image au Moyen Âge. Actes du colloque d'Amiens, 19-23 mars 1986, Amiens, Centre d'études médiévales, Université de Picardie (Wodan, 15. Serie 3: Tagungsbände und Sammelschriften, 5), 1992, p. 127.
} 
parecidas, dejando así clara constancia que pertenecen a este autor la mayor parte de ellas.

Observando el total de las miniaturas que componen este manuscrito, apreciamos que Enéas contiene 8 miniaturas, Troie 32 y Thèbes 14, que se distribuyen a lo largo de las novelas, bien en escenas aisladas o en dípticos.

Según Laurence Harf-Lancner, «Le Roman de Thèbes est le plus illustré avec 14 enluminures pour 9000 vers et 41 folios, suivi de près par Le Roman de Troie et ses 32 miniatures pour 30000 vers et 105 folios; Le Roman d'Enéas est deux fois moins illustré que les deux autres, avec seulement 7 miniatures pour 10000 vers et 38 folios ${ }_{131}{ }^{\prime}$. Pero Laurence Harf-Lancner omite la miniatura que corresponde al entierro de Pallas y que analizaremos más adelante en el apartado al que corresponde la miniatura, cuyo tema central es la guerra.

Tal y como lo expone ya E. Baumgartner, en relación con los manuscritos de Lancelot, «l'illustration initiale ne concerne que le premier épisode du texte et tend en outre à donner une sorte de biographie picturale du héros $132^{»}$. Esta afirmación la podemos aplicar a la página inicial del roman d'Enéas, dado que en esta miniatura inicial, el miniaturista nos expone el primer episodio de la novela, el episodio de Dido y Eneas. Sin embargo, las otras dos páginas iniciales de este manuscrito muestran una visión general de las novelas a las que pertenecen, y no sólo se centran en la primera parte narrativa de las novelas sino que representan las escenas principales de las diferentes partes en las que se dividen Troie y Thèbes.

Hay que destacar que las miniaturas, en su mayoría, representan los dos temas tratados en este estudio, siendo la guerra el tema más desarrollado, sobretodo para la novela de Troie, en la que las únicas miniaturas cuyo tema es el amor se refieren al rapto de Helena, que indirectamente también representa la guerra, así como la entrega

131. Harf-Lancner, Laurence, «L'élaboration d'un cycle romanesque antique au XIIe siècle et sa mise en images: Le roman de Thèbes, Le roman de Troie et le Roman d'Énéas dans le manuscrit BN français 60 », Le monde du roman grec. Actes du colloque international tenu à l'École normale supérieure, Paris 17-19 décembre 1987, éd. Marie-Françoise Baslez, Philippe Hoffmann et Monique Trédé, Presses de l'École normale supérieure (Études de littérature ancienne, 4), Paris, 1992, p. 293. 
de Briseida a Calchas. En efecto, la Guerra, tema heredado de la canción de gesta, y el amor, que poco a poco va ganando terreno en la literatura medieval, serán, junto con las numerosas y detalladas descripciones que aparecen en "les romans antiques", lo que caracterice a esta nueva literatura que nace en la Edad Media, creada de traducciones/ adaptaciones clásicas, y sirve como estímulo a la literatura posterior.

Expongo a continuación una serie de miniaturas que he seleccionado, que aparecen en varios manuscritos citados en la imagen correspondiente y pertenecen al mismo miniaturista. Al observarlas podemos apreciar que todas tienen características muy similares, teniendo todas ellas un sello propio que identifica al autor. La última figura de esta serie corresponde al manuscrito por el cual adquiere su nombre: le roman de Fauvel. 


\section{MINIATURAS DU “MAÎTRE DU ROMAN DE FAUVEL"}

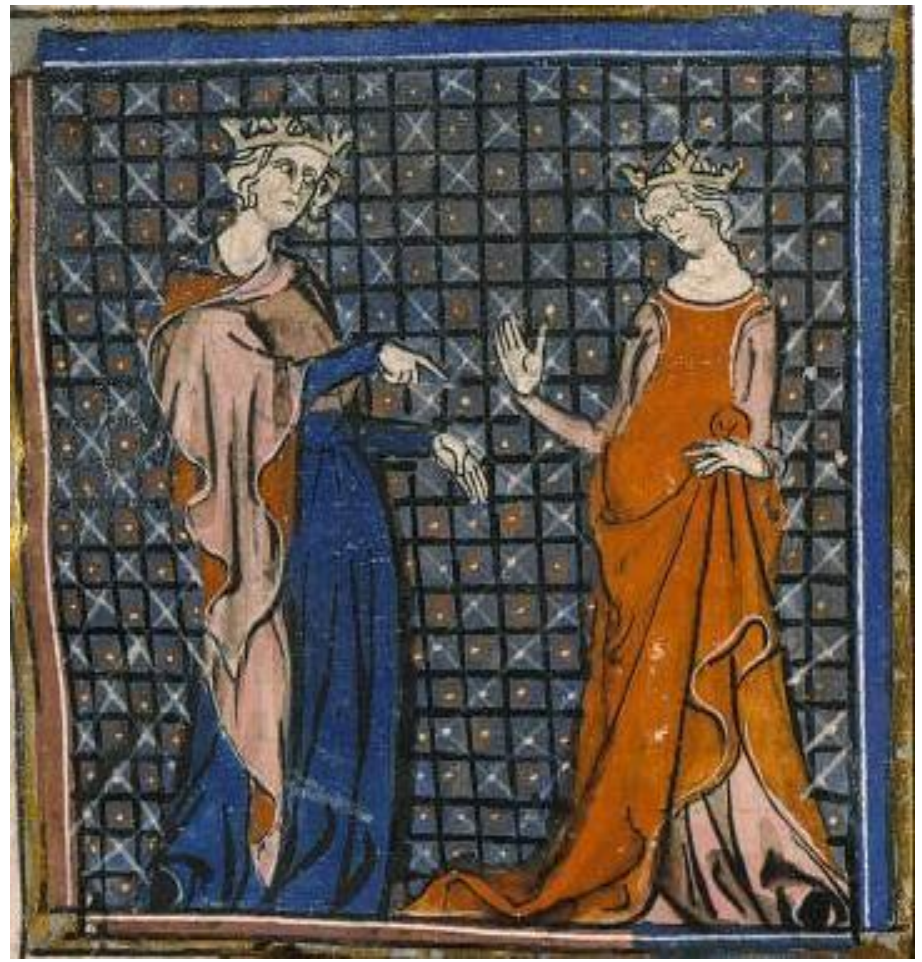

Fig 1. Maître de Fauvel. Le manuscrit 22 Bible historiale de Guyart des Moulins

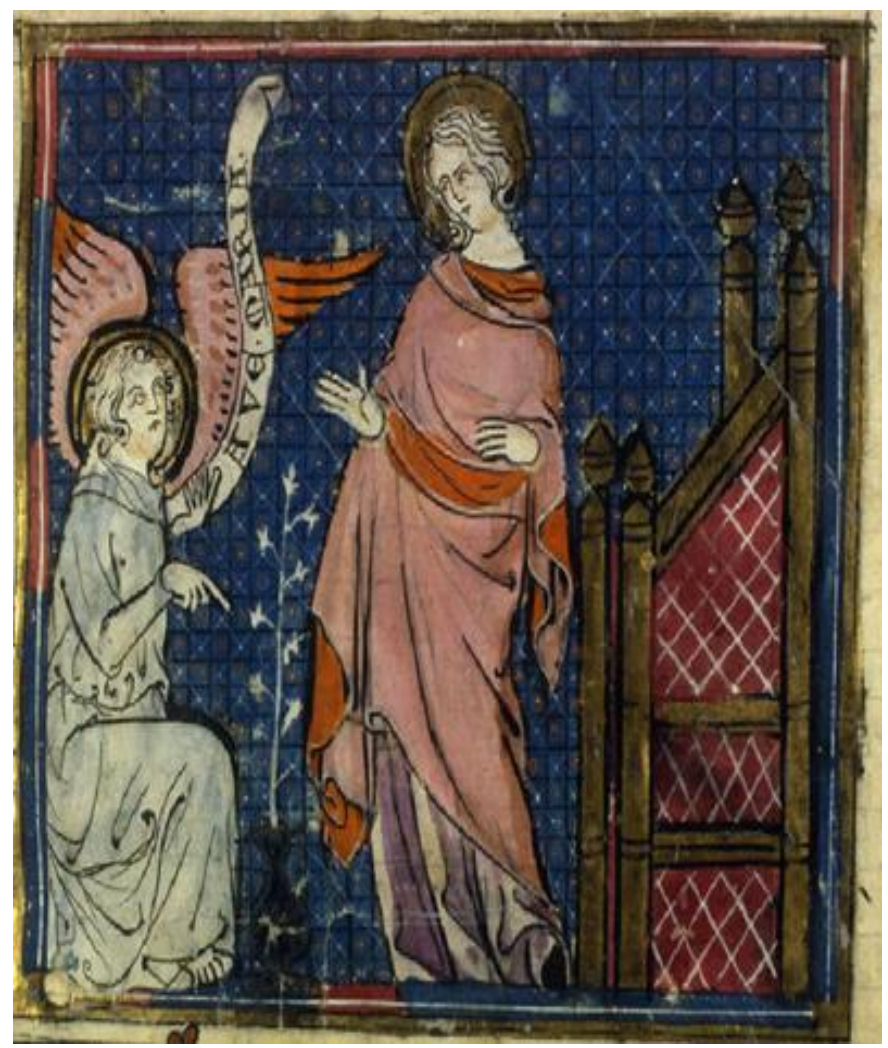

Fig.2. Maître de Fauvel, Enluminure pour 1'Histoire du Saint Graal 


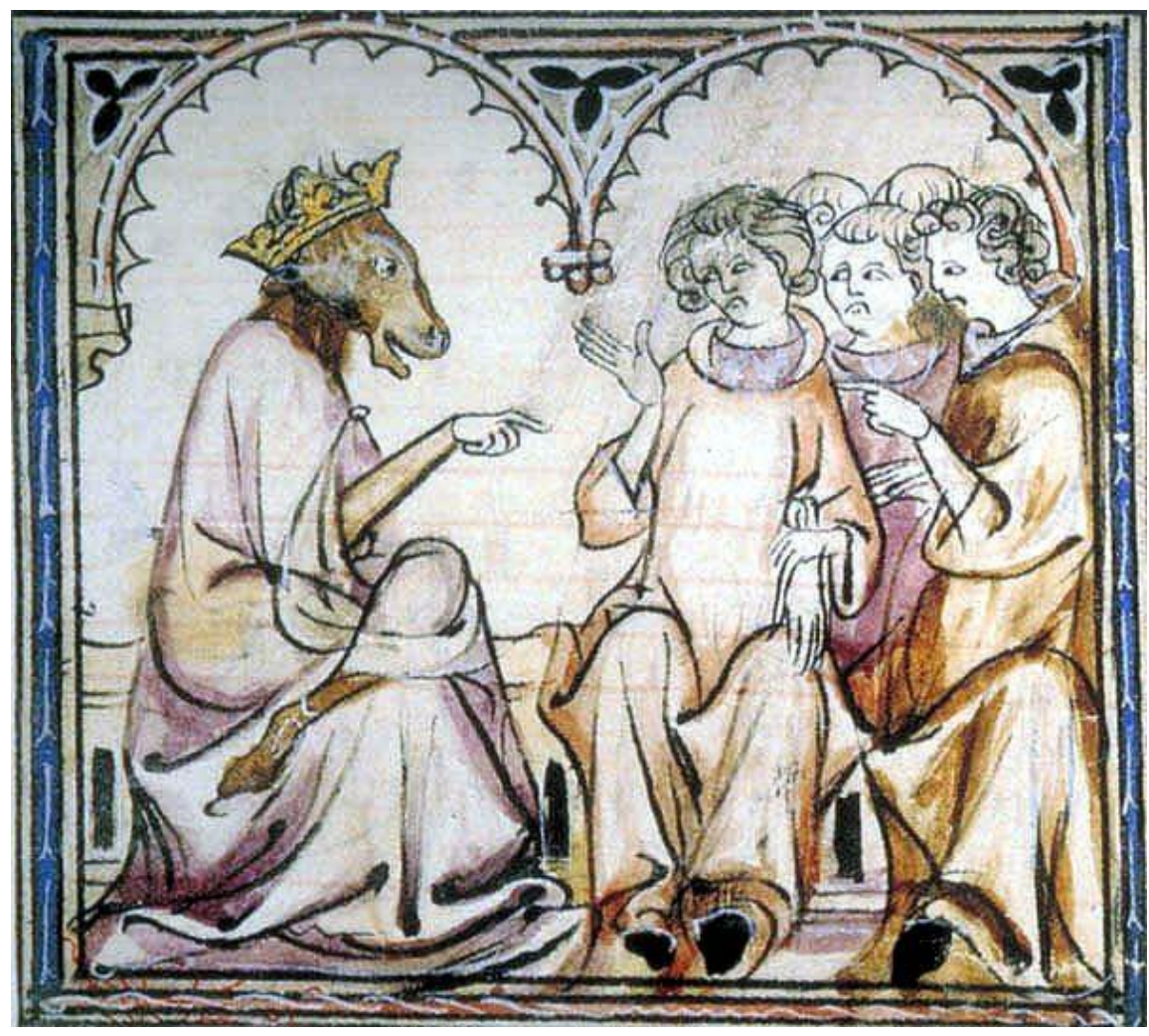

Fig. 3: Maître de Fauvel. Le roman de Fauvel de Gervais du Bus Manuscrit France, XIVe siècle 


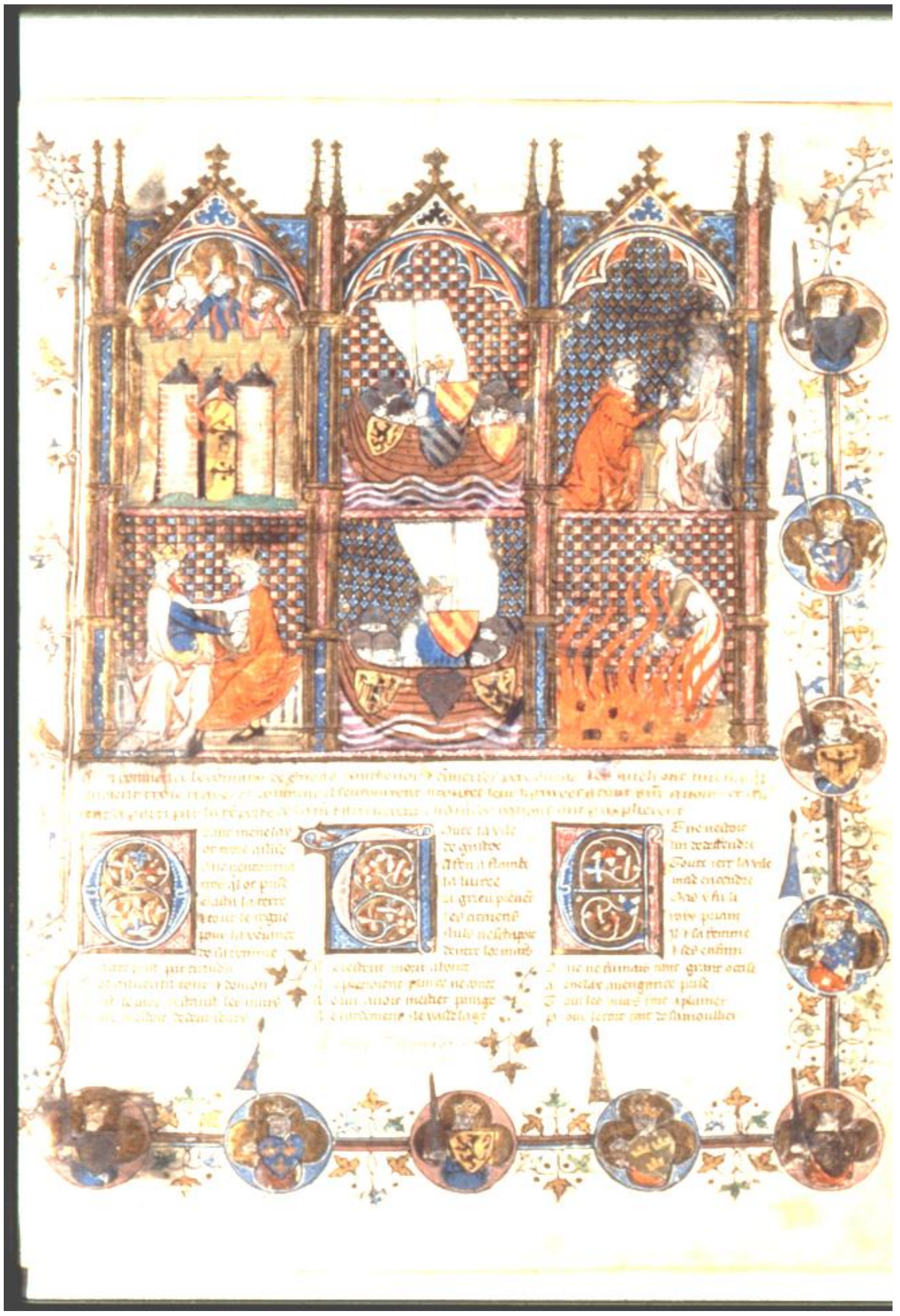


Antes de abordar otras miniaturas, nos detendremos en el análisis de las páginas iniciales en las que aparecen dos grandes temas: Amor y Guerra. Dichas miniaturas, ocupan prácticamente la totalidad de la página y aparecen al inicio de cada novela. Estas páginas se conforman de 6 miniaturas en el caso de Enéas y de tres miniaturas en el caso de Troie. Cada una de diferente tamaño, proporcionado a la importancia narrativa que tiene el hecho referido dentro del texto: sin duda, la representación de las escenas en las miniaturas está afectada por el peso narrativo que tiene el correspondiente episodio.

La miniatura que encabeza la novela de Enéas está dividida en 6 imágenes que aluden a la primera parte de la novela: la caída de Troya, la trama amorosa de Eneas y Dido, la huida de Eneas y la muerte de Dido tras el abandono de su amado. Esta primera gran miniatura que encabeza la novela expone de forma iconográfica los dos grandes temas de la novela: el amor y sus consecuencias y la guerra. La segunda parte narrativa de la novela no aparece representada en imágenes (descenso a los Infiernos, lucha contra Turno y desenlace final), salvo el primer periodo de Eneas, subrayando las cualidades negativas de su primera fase y reforzando el ideal de caballero al que llegará Eneas en su segunda etapa.

Enmarcadas en lo que parece un fondo arquitectónico de un castillo o una catedral, estas imágenes aparecen rodeadas de una decoración vegetal y de representaciones de varios reyes con indumentaria de caballero, y diferentes escudos que reflejan a su vez el anacronismo tan característico de estas novelas, así como la división social que regía en la Edad Media.

\footnotetext{
** Análisis de las diferentes miniaturas:
} 


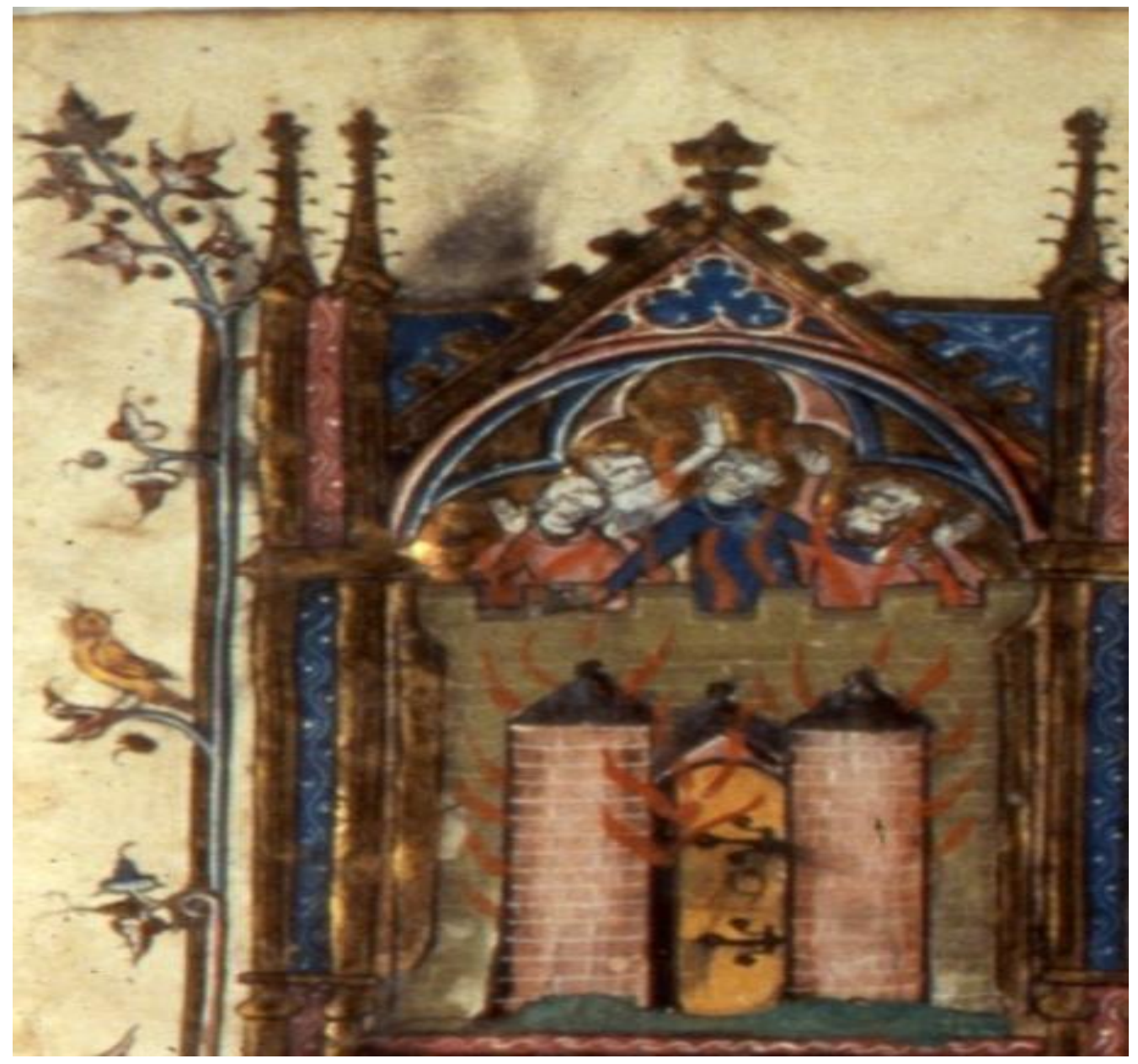

Miniatura 1: nos presenta la destrucción de Troya a manos de los griegos. En un castillo en llamas aparecen atrapados Eneas y sus vasallos que están por debajo de él. Eneas aparece representado con la corona, símbolo de poder que le caracterizará en todas las representaciones de esta página.

Eneas a pesar de no poseer tierra conserva su jerarquía social. En la novela aparece descrito como un caballero en busca de una nueva tierra para gobernar; es el heredero sin reino, posee la corona pero no la tierra para gobernar, tierra que le proporcionará Lavinia heredera de un trono y no Dido que ya es reina y posee Cartago. 


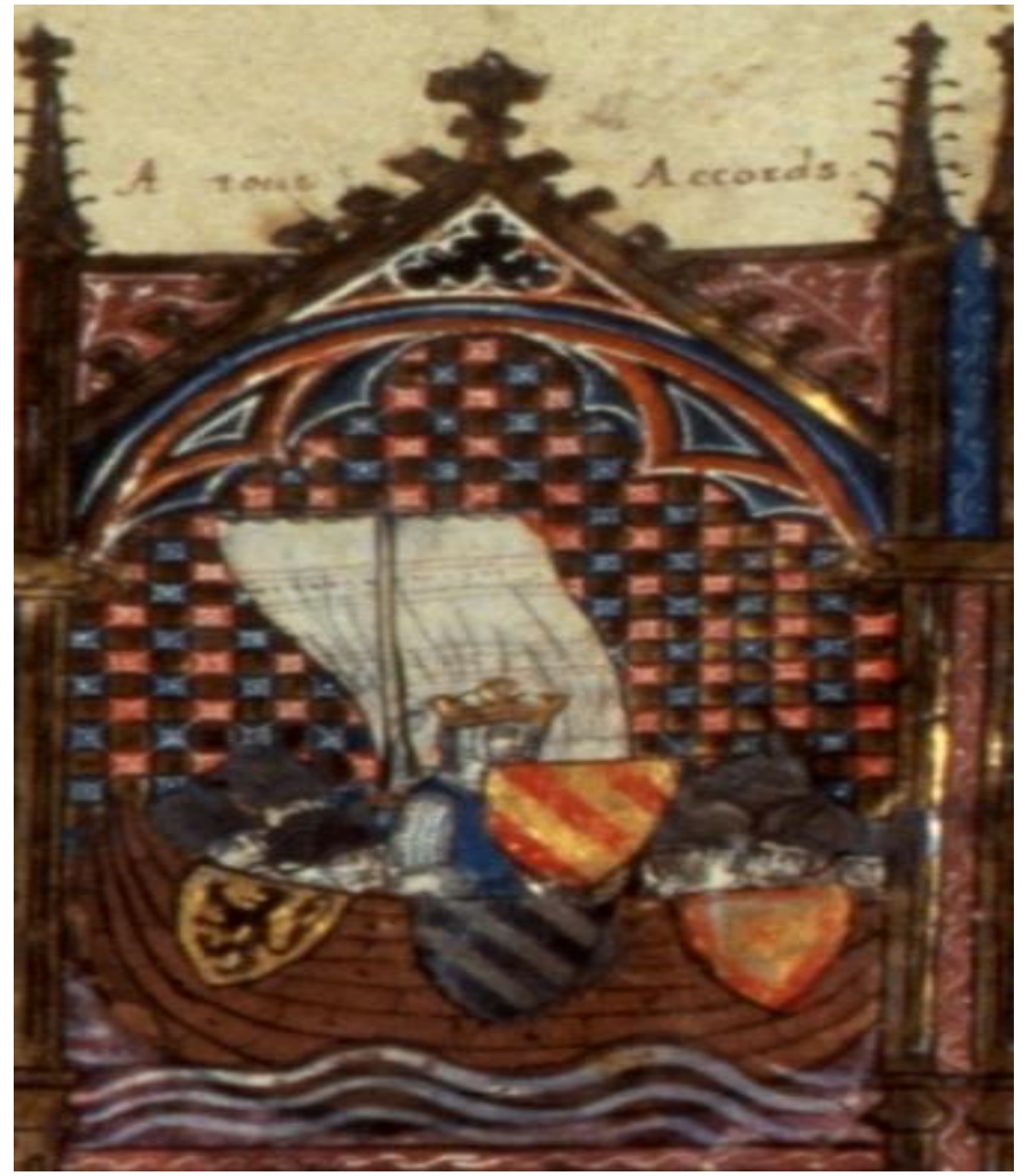

Miniatura 2: nos muestra la huida de Eneas y de sus vasallos en un barco. El personaje más visible y diferenciado es Eneas, quien lleva el escudo y la corona que manifiestan la clase guerrera y la real, primera dualidad que se representa en la primera etapa de Eneas, mientras que sus vasallos aparecen muy poco diferenciados, vestidos con la armadura de caballeros medievales. Es evidente que el miniaturista, durante toda la serie, pretende dar importancia a Eneas como personaje principal a través de su detallada representación. Los personajes secundarios aparecerán como simples esbozos, sin rasgos que les distingan los unos de los otros. Sigue presente la jerarquía social medieval en la imagen donde aparecen los vasallos situados por debajo de Eneas. 


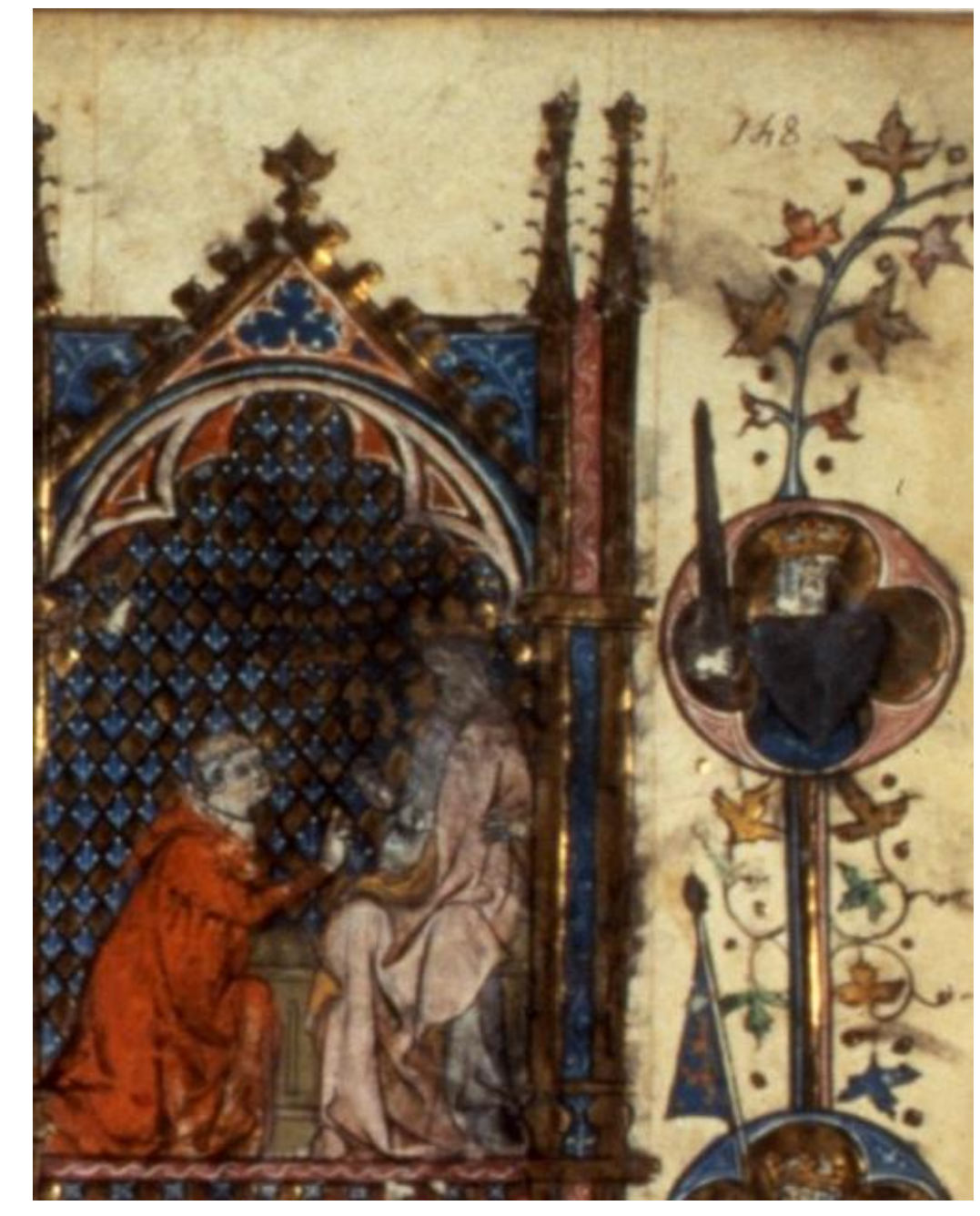

Miniatura 3: Representa a Eneas con Dido coronada y sentada en el trono. Ella está dibujada tal y como lo describe el texto, resaltando su faceta de reina, que analizamos en el primer capítulo de nuestro trabajo, mientras Eneas aparece en esta miniatura sin corona (la única ocasión) y con una simple túnica. Su actitud de súplica ante la reina Dido impide que se le represente como a un rey o a un caballero.

En esta miniatura la representación de Eneas se asimila a la de un mensajero. En efecto, al estudiar otras miniaturas en las que aparecen mensajeros (como en las pertenecientes a Troie), nos hemos dado cuenta de que las representaciones son exactamente iguales. Aparece aquí la primera variación del miniaturista con respecto a la novela escrita ya que en dos ocasiones la novela apunta que no es el propio Eneas sino los mensajeros enviados por él los que acuden a Dido para pedirle asilo: 
Danz Eneas adont chosy

III des suenz preuz et hardy

Qui le paÿs aillent cerchier

et si li sachent renoncier

en quel paÿs sont arrivé,

s'il y a ville ne cité.

(V.244-249)

Devant li vienent li mesaige;

Ilïonus parla premiers,

Li plus saines des mesaigiers.

(V. 541-543)

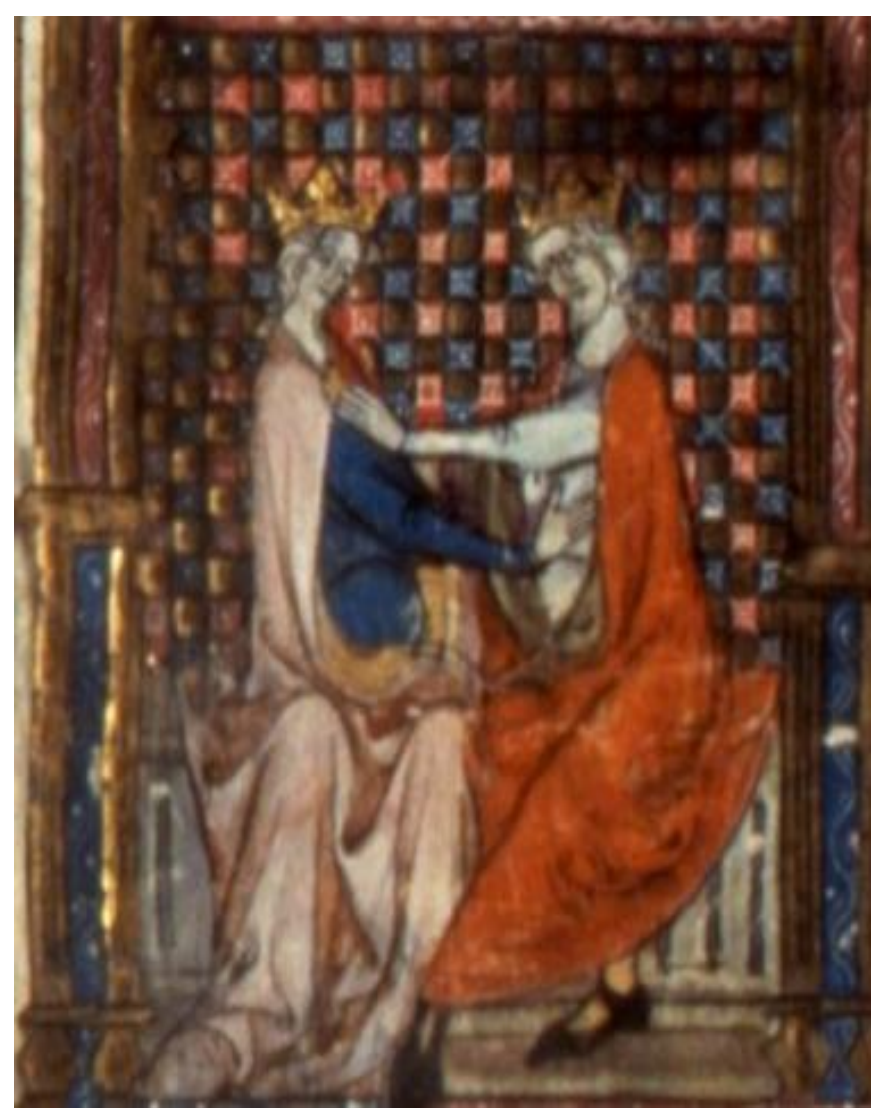


Miniatura 4: Muestra a Eneas y a Dido sentados juntos y entrelazados, haciendo patente la unión de ambos. La representación de los dos personajes es de unos reyes, ya que los dos llevan corona y están situados al mismo nivel, rompiendo con la escena anterior donde Dido se mostraba superior a Eneas debido a su estatus social; un Eneas todavía sin tierra, posible explicación a la ausencia de corona en la representación anterior. Esta miniatura 4 desarrolla ya una de las características más destacadas de las cualidades de Dido muy presente en la novela, la de reina de Cartago.

Por de pronto, constatamos que únicamente están representados los niveles superiores de la sociedad y los protagonistas del texto. Cabe apuntar en este sentido la idea que desarrolla Laurence Harf-Lancner: "les manuscrits de l'Enéide peignent rarement le héros avec une couronne. Or dans les miniatures du manuscrit $\mathrm{BN}$ fr 60 , aux côtés de Didon, toujours couronnée, Enée porte également une couronne ${ }_{133}$ ”. En este sentido la miniatura 3 destaca por ser la única miniatura en la que Eneas aparece sin corona.

133. Harf-Lancner, Laurence, « Les manuscrits enluminés de l'Énéas: assonances et dissonances du texte et de l'image », L'image au Moyen Âge. Actes du colloque d'Amiens, 19-23 mars 1986, Amiens, Centre d'études médiévales, Université de Picardie (Wodan, 15. Serie 3: Tagungsbände und Sammelschriften, 5), 1992, p.130. 


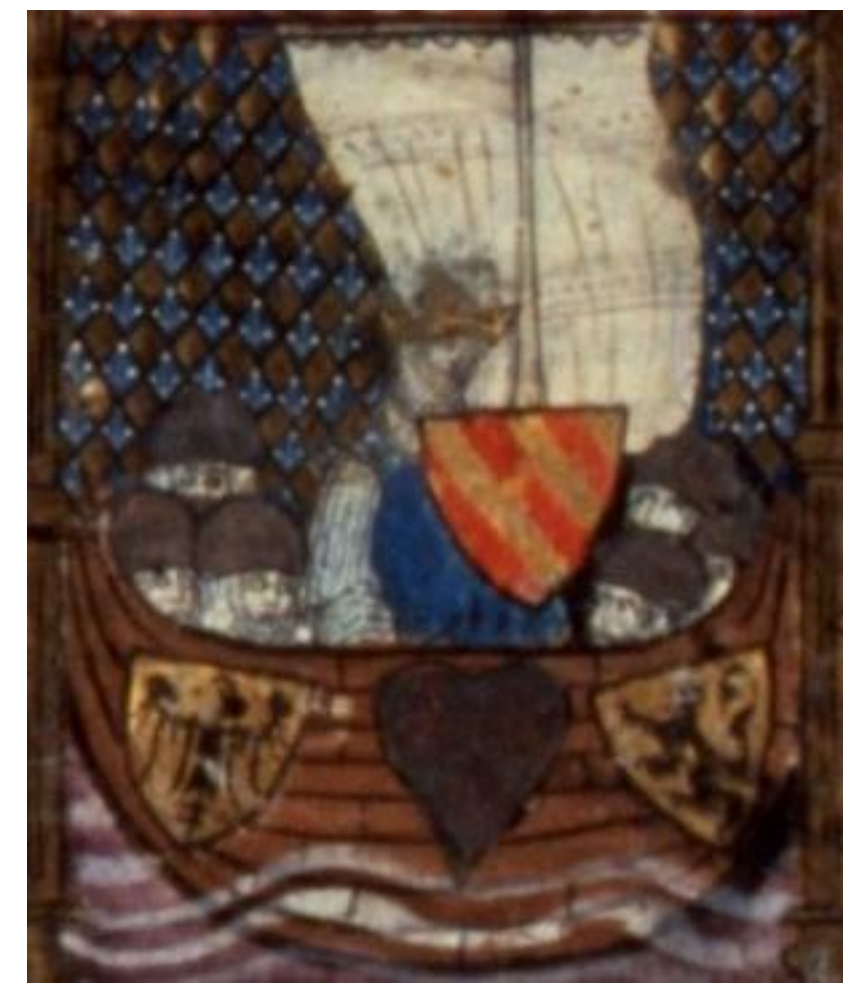

Miniatura 5: Nos muestra la huida de Eneas en barco. Tanto la llegada como la huida de Eneas de la tierra de Dido están representadas de la misma manera, lo único que varía es la posición de la vela situada a la izquierda y que anuncia la partida de Cartago y el fatal desenlace de Dido. Así las representaciones de la segunda y la quinta miniatura son prácticamente idénticas, dejando patente lo escueto y simple de estas miniaturas, características que las hacen directamente comprensibles para un extenso público. 


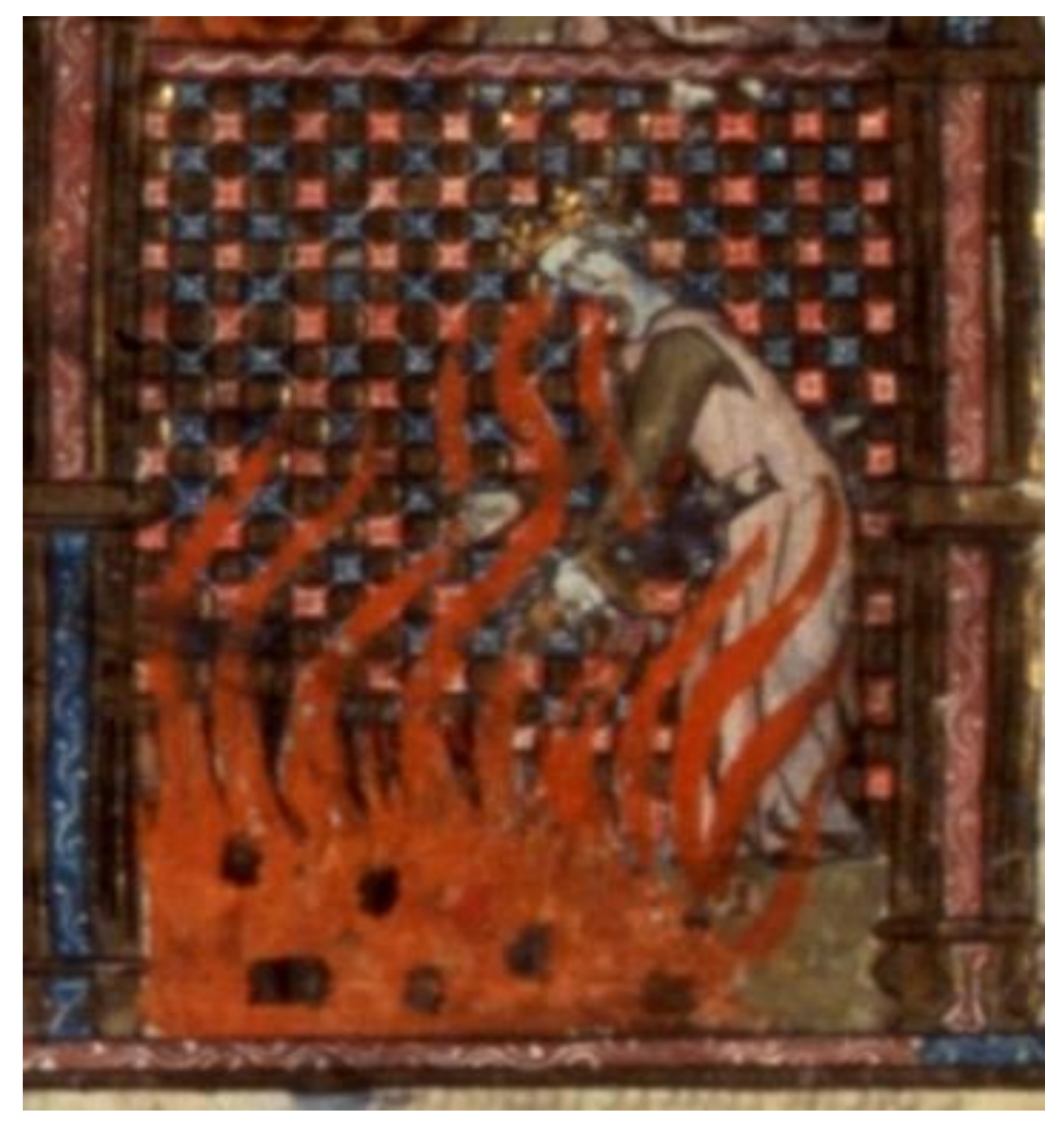

Miniatura 6: Muestra la muerte de Dido, tal y como nos la describe la novela: Dido primero se hiere con la espada de Eneas y después cae en una pira ardiendo preparada por su hermana. La representación de las miniaturas acaba igual que empieza, con la destrucción. El fuego, que ha destruido Troya, mata a Dido y purifica a Eneas, quien comienza tras este episodio su etapa positiva. Recordemos, como lo exponemos en el primer apartado, que la primera etapa de Eneas es negativa y así lo muestran las miniaturas de la primera página del Enéas que se ciñen a la primera parte de la novela. La presencia de la espada hace pensar que, a pesar de ciertas variaciones frente a lo escrito que analizaremos más adelante, el autor de la miniatura conocía muy bien la novela por los detalles que representa en las miniaturas y están presentes en la novela:

En la chambre tout seulement

n'est qui li destorbe noient

la deverie que voult faire; 
l'espee au Troÿen veult traire:

quant li donna, ne cuida mie par li deüst perdre la vie.

Elle tient l'espee toute nue,

Souz la mamelle s'est ferue.

O tout le cop saut enz el ré

Que sa serror ot apresté,

(V. 2110- 2119)

En estas representaciones sigue presente el anacronismo, tanto en los edificios como en la vestimenta que llevan los protagonistas. La jerarquización de la sociedad medieval está representada en la posición de los personajes en la miniatura que da un lugar privilegiado a la primera función, la de rey por encima de las demás, exponiéndose al mismo tiempo los valores del caballero.

La huida de Troya con sus vasallos, la llegada a Cartago y el enamoramiento de Dido, su abandono y el posterior suicidio de la reina, conforman la representación de la etapa negativa de Eneas. Las llamas que arrasan Troya arrasan a su vez a Dido que pierde su reino por culpa de Eneas. La destrucción de Troya continúa con la destrucción de la reina Dido; acontecimiento que marcará a Eneas durante toda su trayectoria y será recordado por la madre de Lavinia como algo nocivo.

La representación del suicidio, que en la mentalidad medieval estaba muy castigado, puede interpretarse tal y como nos expone Marie Noëlle Lefay-Toury "Ce n'est pas la mauvaise conduite pendant la vie terrestre qui constitue le critère du châtiment; le critère est uniquement la folie amoureuse considérée comme un mal en soi et qui suffit à entraîner ses victimes dans un malheur éternel ${ }_{134} \gg$. El suicidio no es sino la consecuencia de esta locura de amor que asalta a la reina de Cartago. A esta acción se le da esta interpretación en la Edad Media: "La pensée théologique médiévale considère comme vicieuse la conduite quidétermine la mort d'une personne ou d'une société, le terme mort devant être pris dans le sens physique et dans le sens spirituel. La pratique 
du vice assujettit l'être à une passion qu'il subit. Il se détruit lui-même inéluctablement par les excès auxquels il se livre ${ }_{135}{ }^{»}$

Las representaciones de suicidios son muy frecuentes en los manuscritos de la Edad Media y, prueba de ello son las siguientes muestras de diferentes personajes suicidándose, utilizando la espada como utensilio recurrente en todo suicidio, que exponemos a título ilustrativo:

135. Garnier, F., Le langage de l'image au Moyen Age : grammaire des gestes, Tomo 2, Paris, Le léopard d'or, 1982, p. 278. 


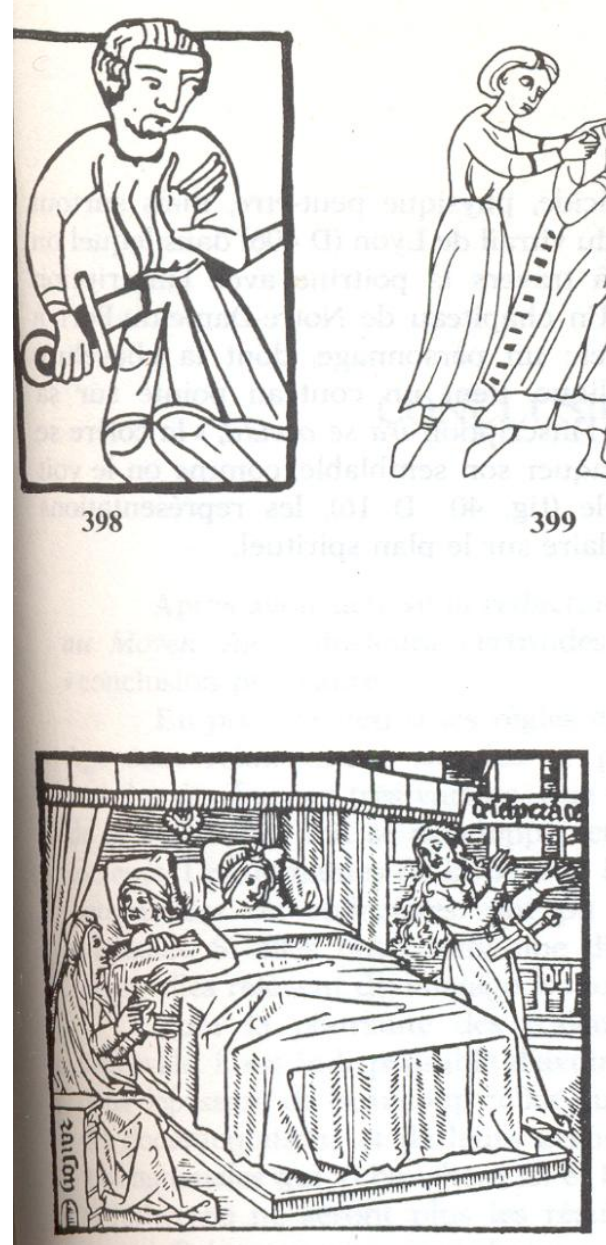

401
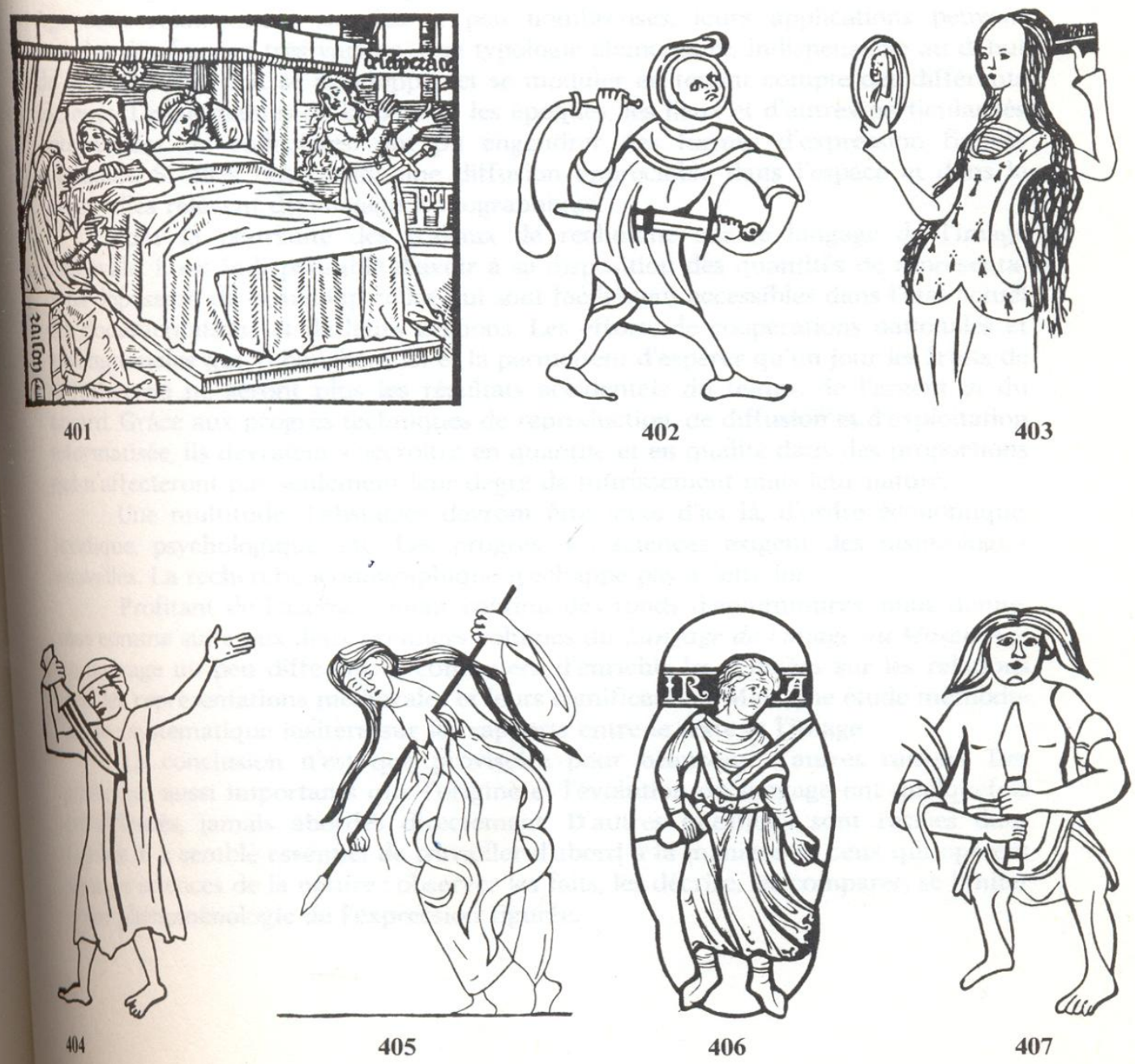


\section{Suicide de Saül.}

Initiale du second Livre de Samuel, Factum est autem potquam mortuus est Saül, Bible du XIII siècle. Dole, bibl. mun. ms.17, fol. 117v (fig.216)

399 Suicide de Saül poussé par l'Amalécite

Initiale du second Livre de Samuel, Factum est autem, Bible, première moitié du XIII ${ }^{\mathrm{e}}$ siècle. Reims, bibl. mun., ms. 35, fol. 76v.

\section{Suicide de Didon}

Histoire universelle, troisième quart du XIII ${ }^{\mathrm{e}}$ siècle. Dijon, bibl. mun., ms. 562, fol.114.

401. Figure allégorique de Désespérance opposée à Raison

Gravure. Pierre Gringore, Le château de Labour. Paris, 1499.

\section{Suicide de l'insensé}

Initiale du psaume Dixit insipiens, Bible du XIV ${ }^{\mathrm{e}}$ siècle. Bibl.Mazarine ms.34, fol.202 (fig.217).

403 Femme de mauvaise vie se regardant dans un miroiroù elle voit qu'elle se condamne à la damnation après sa mort.

Jacques le Grant, Le livre des bonnes mœurs, $\mathrm{XV}^{\mathrm{e}}$ siècle. Chantilly, Musée Condé, ms. 1338 (fig.159).

404 Homme se suicidant par désespoir

B.m., Oxford, fol.148.

405 La Luxure se suicide en se transperçant la poitrineavec une lance.

Fresque du XII ${ }^{\mathrm{e}}$ siècle. Crypte de Tavant.

406 La Colère se passe une épée à travers le corps.

Détail d'un vitrail de Lyon du XIII'siècle, d'après L. Bégule.

407 La Colère se tue "Ira se occidit".Chapiteau du XII ${ }^{\mathrm{e}}$ siècle. Clermont- Ferrand, NotreDame-du-Port 136 . 


\subsubsection{PÁGINA INICIAL DE TROIE:}

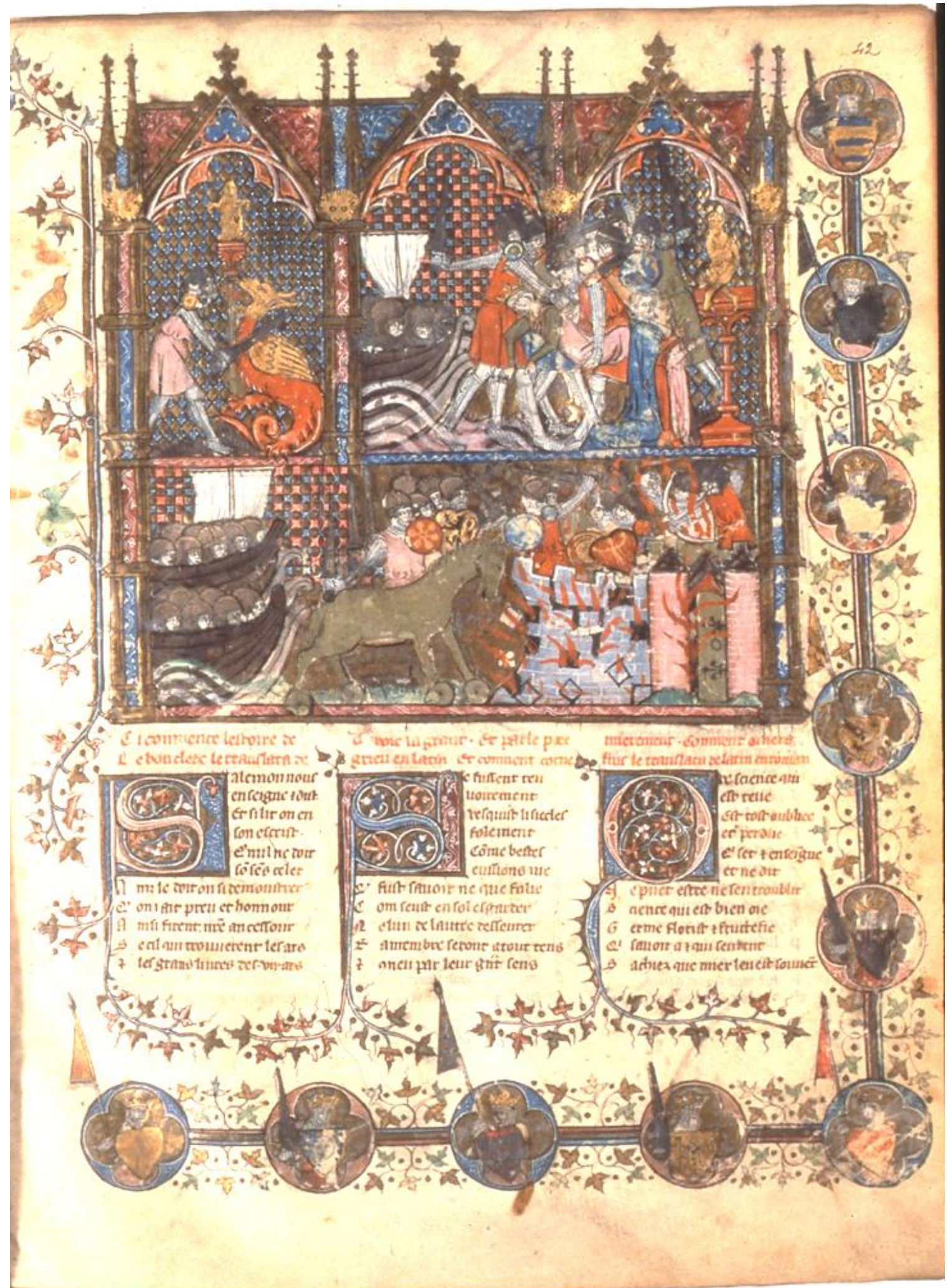


En esta página inicial del Roman de Troie, llama tanto la atención el número reducido de miniaturas, la mitad que en la página inicial del Roman d'Enéas, como el contenido de sus representaciones.

En efecto, las miniaturas de la página inicial de Troie tratan las tres etapas más destacadas de la estructura narrativa de la novela, de tal modo que esta página ofrece un breve resumen del conjunto de la novela, no solamente de la primera parte como la del Enéas.

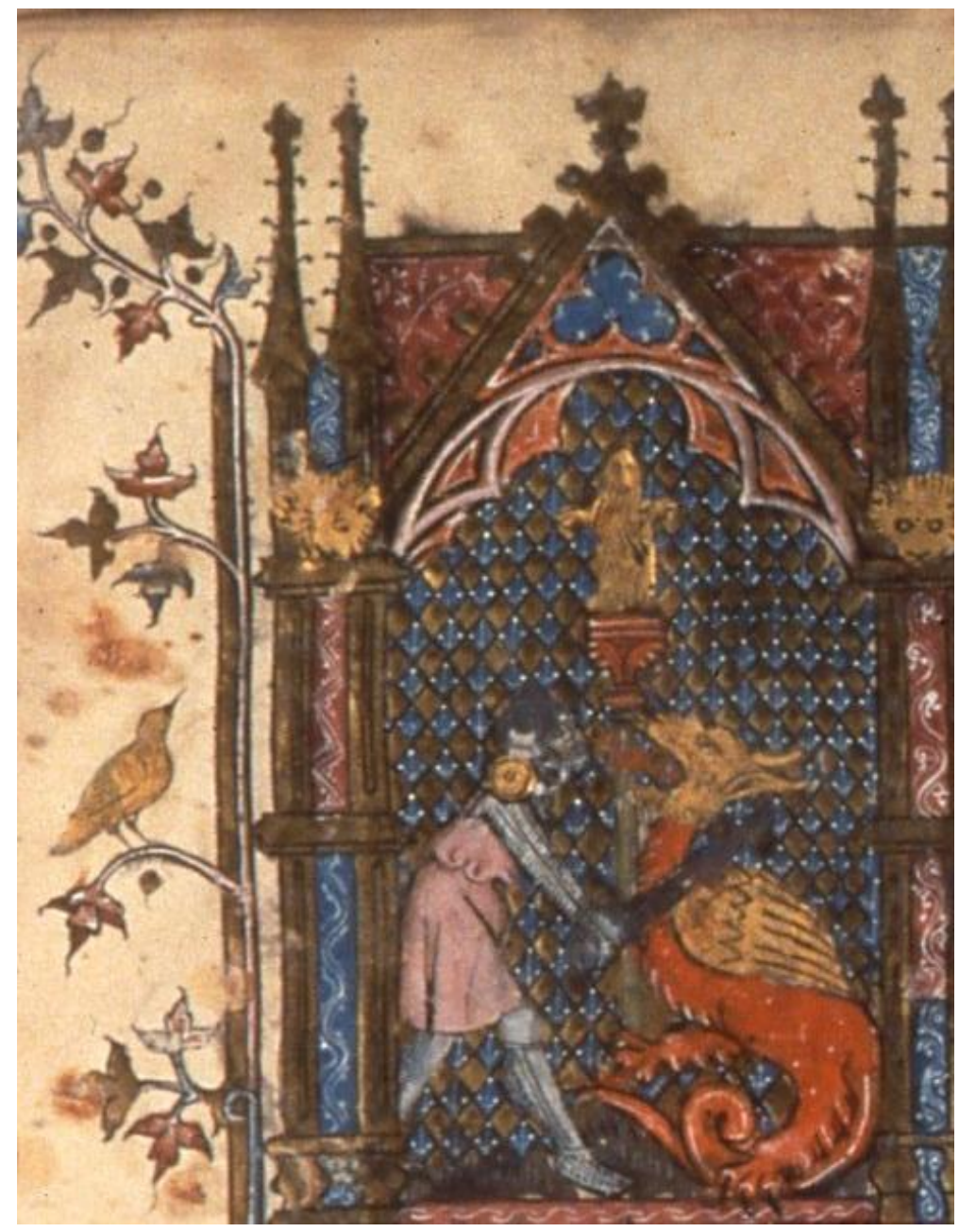

Miniatura 1: Se centra en el primer episodio que abre la novela: la conquista del vellocino de oro por Jasón. Podemos ver cómo Jasón, vestido como un caballero 
medieval, lucha contra un monstruo mitad dragón mitad león y con cola de serpiente para conseguir el vellocino de oro que está situado en un altar presidiendo la escena de la lucha. En esta imagen observamos una reinterpretación del monstruo por parte del artista ya que, siguiendo la descripción de la novela, se expone al monstruo, que protege al vellocino, como a un dragón de grandes dimensiones y, sin embargo, en la miniatura, el dragón aparece con las mismas dimensiones que Jasón y claramente adaptado a la intención del autor, la de engrandecer a Jasón:

"Encor i a el passer

Qui assez fait a redoter:

Quar uns serpenz qui toz jors veille,

Qui pas ne dort ni ne someille,

Le regarde de l'autre part

Par tiel engin e par tiel art

Que ja riens n'i apresmera

Si poi come senpres morra,

Quar fue gete ensenble o venin

Qui tost li a doné la fin.

Granz est e fiers e trop isdous,

Ainc hon ne vit si merveillous.

(V. 1367-1378)

Aparece así expuesta desde el inicio de la novela la importancia del valor caballeresco. Tal y como lo hemos expuesto en el primer punto de nuestro trabajo, en Jasón prevalece el espíritu guerrero y de caballero frente al de hombre enamorado.

Después del análisis global de la miniatura, podemos decir que el autor omite la representación de la figura del dios Marte que era el que en la mitología guardaba el vellocino de oro, tal y como lo reproduce el texto de Benoît. La representación del vellocino de oro resulta así diferente a las que nos han llegado a lo largo de la historia. Se ve reflejado en la miniatura el deseo de desmitificación de los dioses paganos, como hemos ido apuntando a lo largo de nuestro trabajo en cuanto a la propia translatio. 
También esta miniatura, que encabeza la página de la novela, refleja ya el tema de la guerra, hilo conductor de Troie.

Marz i a mis dous bués d'arain.

Quant ire e mals talenz les toche,

Par mi les nés e par la boche

Jetent de lur cors fue ardant.

Ja de la mort n'avra garant

Quin iert ateinz ne conseüz;

Senpres ardra cum se c'ert fuz.

Par art e par conjureison

Ont cil en garde le mouton.

Qui la Poison voudra aveir,

Si convendra par estoveir

Que il les puisse si donter

Que traire les face e arer.

Marz, li poissanz dex de Bataille,

Les i a ensi mis sens faille.

(V. 1352-1366)

Estos versos nos permiten comprobar que Benoît de Sainte-Maure insiste en la referencia al dios Marte en el relato correspondiente, con un fin sin duda anecdótico; sin embargo el miniaturista lo omite por completo, dando prioridad a la hazaña de Jasón al conseguir el vellocino de oro, y exponiendo sus dotes de caballero tan importantes en la Edad Media. También hay que señalar la ausencia de Medea, que no aparece ni en la página inicial ni en las páginas posteriores; esta ausencia pone de relieve el interés del artista por la hazaña guerrera más que por la faceta femenina del episodio amoroso del caballero.

Por otra parte, cabe insistir, como ya he mencionado en la introducción, en que el tamaño de las escenas es proporcional al peso narrativo que tiene en la novela. Así, podemos observar que las miniaturas a las que se les concede mayor peso son el rapto 
de Helena y la destrucción final de Troya, que coinciden con una de las etapas decisivas en la novela y a su vez con las partes que ocupan un mayor número de versos. De esta manera, el miniaturista ya anuncia cuáles son los temas claves de la novela.

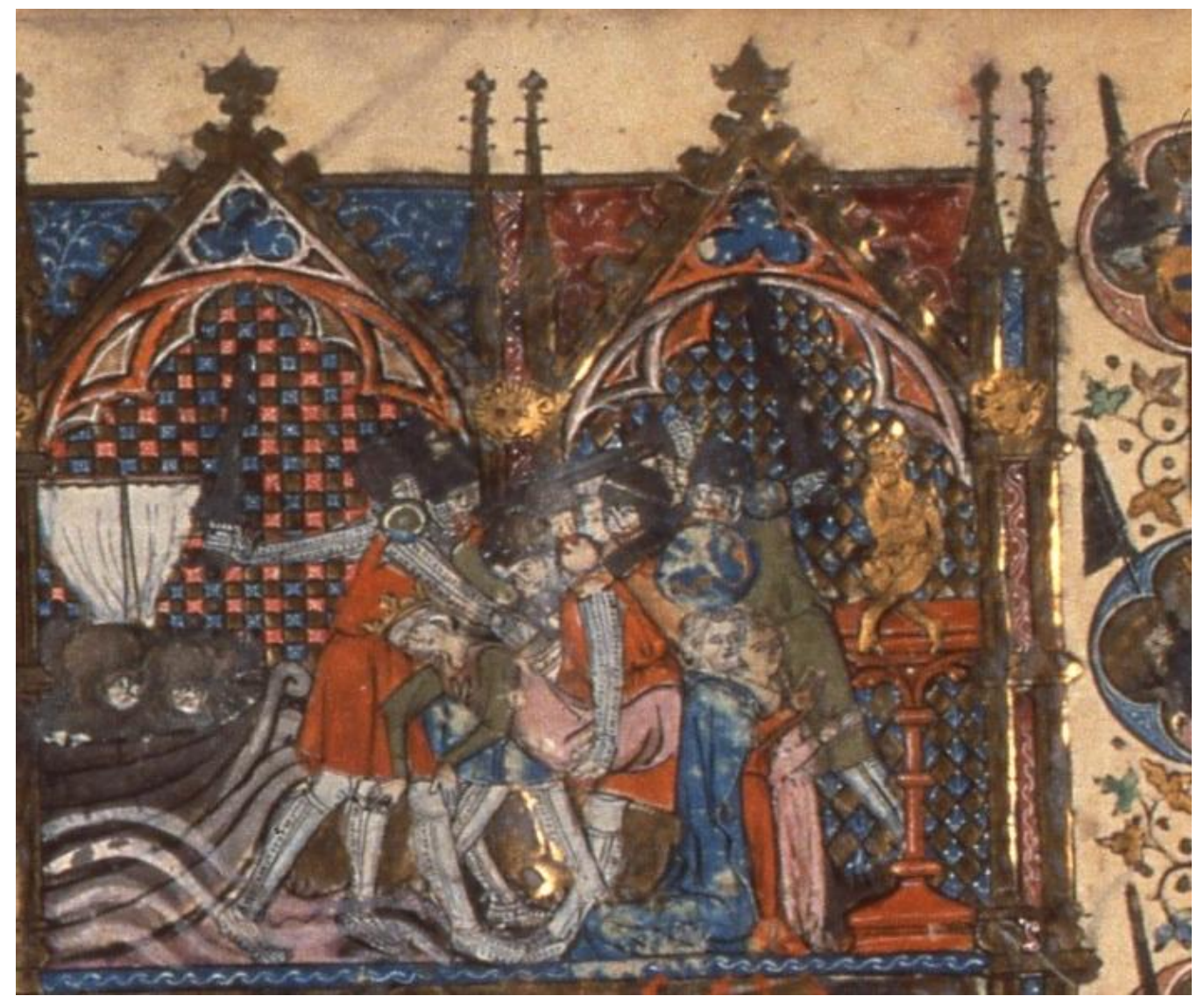

Miniatura 2: nos muestra el rapto de Helena en el templo. Según la novela se trata del templo de Venus, sin embargo el copista procede como en todas la representaciones de los dioses, es decir, sin darle ningún aspecto característico al dios al que señala, mediante una estatua de pequeñas dimensiones y siempre en segundo plano. Este detalle confirma la aminoración de los dioses paganos por la mentalidad medieval, traducida por el descuido de rasgos identificativos.

La interpretación de la historia por parte del copista es evidente en esta miniatura, a través de la actitud de Helena. Si en la tradición, Helena no opone resistencia al rapto troyano y manifiesta su conformidad, en la miniatura podemos 
apreciar un sentimiento de angustia en la cara de Helena que es llevada a la fuerza por varios guerreros que luchan entre ellos; de esta forma, el rapto de Helena para el copista es forzoso y no voluntario, tal y como lo dice Benoît de Sainte-Maure:

** Rapto de Helena :

\author{
Qu'au tenple vindrent tuit armé. \\ Un greile sonent a l'entrée; \\ Chascuns a trait nue s'espee. \\ Isnelement e en poi d'ore \\ Armé, irié, lor corent sore. \\ Maint en detrenchent e ocient \\ E maint en i prenent e lient.
}

La bele e la preuz dame Heleine

I pristrent tote premierereine.

Ne se fist mie trop leidir,

Bien fist senblant del consentir.

Plusors dames, plusors puceles

Prist hon o li, riches e beles.

(V.4496- 4508)

Así mismo, la representación de Venus ya no es la de una dama medieval como en Enéas sino que se reduce a la de una simple estatua. También en Troie, Venus carece de peso en la narración, existiendo sólo alusiones a su figura tradicional de diosa del amor sin que alcance a tener una relación significativa con el desarrollo de la acción.

** El templo de Venus: 


\section{Citerea, ce dist l'autor,}

Aveit a non l'isle a cel jor,

$\mathrm{O}$ il aancrerent lur nés;

Mout iert li tens douz e sués.

\section{Un temple riche e merveillous,}

Mout ancïen, mout precïous,

\section{Aveit en cel isle, en l'enor}

Venus, la deuesse d'amor.

\section{Tuit cil del regne d'environ}

\section{I veneient a oreison.}

Mout iert li temples chiar tenuz:

La aoröent lur vertuz,

La faiseient lor sacrefises

Icil de la terre, a lur guises;

Offrirent i de riches dons

E perneient devins respons.

(V. 4257-4272)

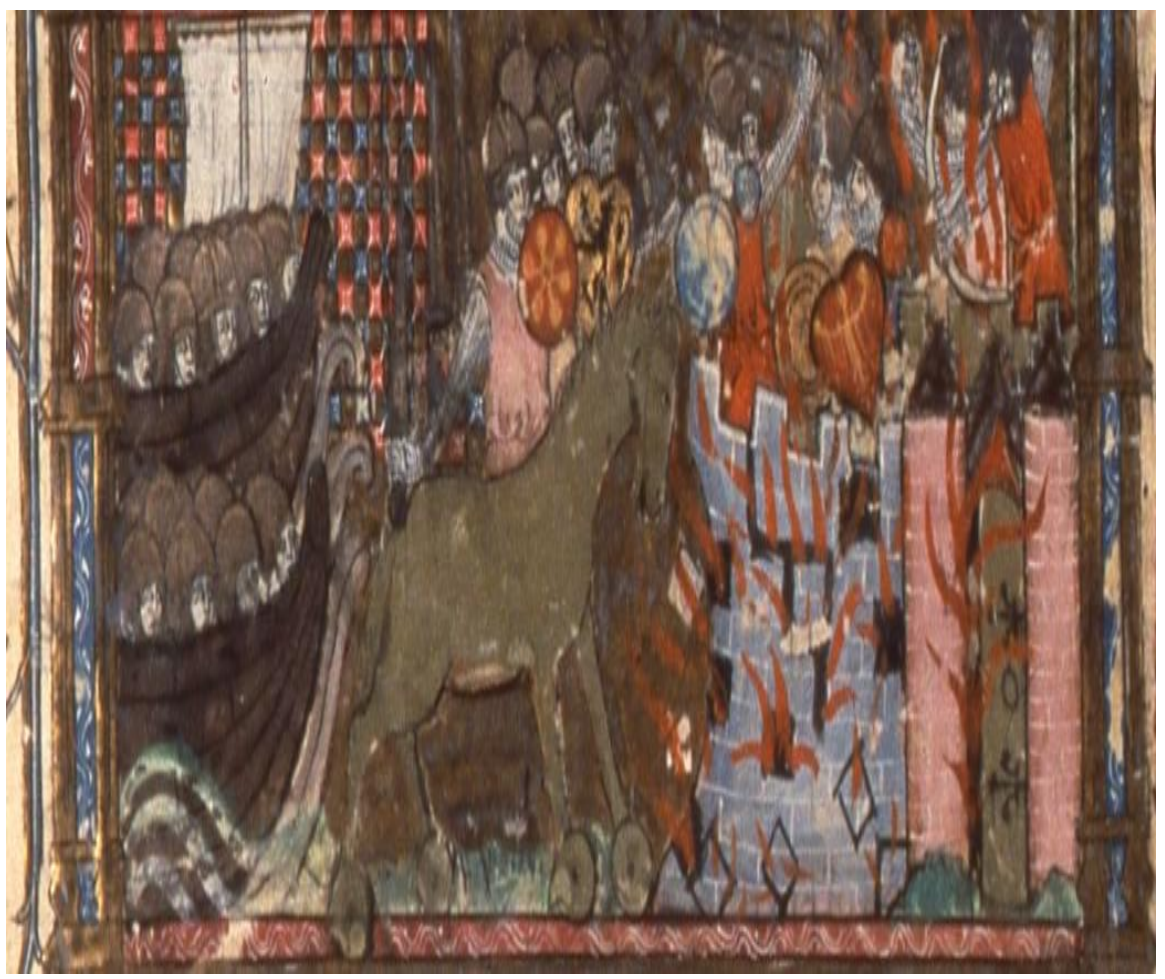


Miniatura 3: representa la destrucción de Troya a manos de los griegos. Aparece de forma significativa en primer plano el caballo de donde surgen los guerreros griegos caracterizados con tonos más claros que los guerreros troyanos y situados en la parte izquierda, escenario que se adoptará en todas las miniaturas. La imagen de los troyanos ya aparece tratada de forma positiva en este manuscrito, siguiendo la idea de Colette Beaume aludiendo al tradicional nexo de unión entre los troyanos y los franceses: "Après 1080, la plupart des familles princières ou contables eurent des généalogies troyennes, et à la fin du Moyen âge tout noble personnage peut se voir citer ses ancêtres troyens $137 \%$.

Esta última miniatura inicial resume la emboscada de los griegos y el posterior asedio de la ciudad. Al observarla podemos ver semejanzas entre esta forma de representar la ciudad de Troya arrasada y la representación de Troya devastada en la miniatura inicial del Roman d'Enéas. Las dos miniaturas cierran y abren las dos novelas, creando así un nexo temático entre ellas. Ambas miniaturas representan la ciudad envuelta en llamas y semejante a un castillo medieval. Asimismo, el amor y la guerra están presentes, representados en las miniaturas, en ambas novelas, desde las primeras páginas del manuscrito.

Por otra parte, la crudeza de la batalla descrita por el autor de la novela se hace patente por los numerosos guerreros representados de forma colectiva, ya que no tienen un rostro muy diferenciado, aunque en esta configuración se puede distinguir el grado de importancia: los guerreros principales están mejor caracterizados en rasgos y movimiento mientras que los simples soldados van a ser representados vagamente sin diferenciarse los unos de los otros y con muy escasa carga gestual. Así se refleja igualmente en el texto esta amalgama gestual:

Grieu troverent les murs funduz

E peceiez e abatuz,

Por la merveille qui iert fete,

Qu'il orent enz tiree e trete.

Vint mile d'els i a entrez;

137. Beaume, C., Naissance de la nation France, Paris, Gallimard, 1985, p. 51. 


\section{Partiz se sunt e devisez}

E par mainz sens e par mainz lués.

Oscurs iert li ciels e la nuiz;

Signes se sunt entredonez.

Ainz que del jor parust clartez,

En orent il vint mile ocis.

Li granz palés de marbre bis

Sunt asailli e depecié,

E cil dedenz tuit detrenchié.

(V. 26043-26056)

Las páginas iniciales, a modo de resumen pictórico, anuncian los episodios más destacados de las novelas, ofreciendo de antemano al lector no sólo un esbozo de la trama y una visión de conjunto, sino también una línea de interpretación temática a través de una selección deliberada por parte del autor de las miniaturas. 


\subsection{EL AMOR EN LAS MINIATURAS DEL ROMAN D'ENÉAS}

En el primer capítulo de nuestro trabajo, estudiamos las dos tramas amorosas de las que se compone la novela de Enéas, la primera en su etapa negativa (Dido), y la segunda en su etapa positiva (Lavinia) y, de esta manera, encontramos ambas secuencias representadas en el manuscrito $\mathrm{BN}$ fr 60, aunque la trama amorosa de Dido cobra mayor importancia, ya que aparece desde la página inicial del manuscrito, donde se desglosan sus diferentes episodios:

- Caída de Troya.

- Huida de Eneas por mar.

- Llegada de Eneas ante Dido.

- Dido y Eneas entrelazados: su relación amorosa es evidente.

- Huida de Eneas de Cartago.

- Suicidio de la reina Dido.

Miniatura 1 y 2, Folio 162: "Comment li roys Latins donna sa fille a Eneas qui ne l'avoit onques veue. Et comment la royne femme du roy Latin manda Turnus a qui elle estoit donée". 

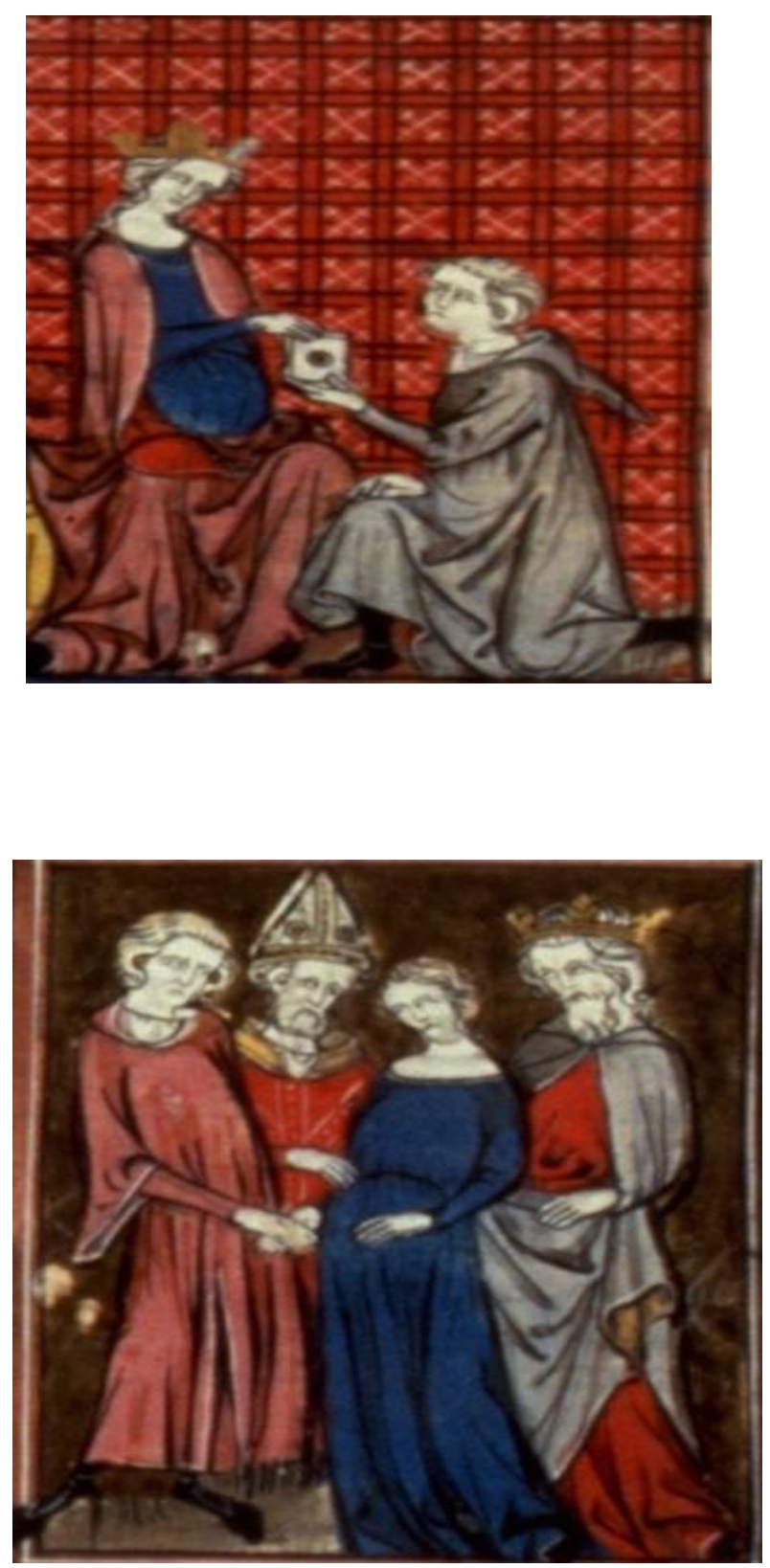

La segunda trama amorosa de Enéas, la de Lavinia, menos desarrollada desde el punto de vista gráfico, aparece sólo en un díptico. En estas miniaturas podemos observar cómo el autor interpreta el suceso con una mentalidad cristiana añadiendo un elemento significativo. En efecto, en la segunda miniatura, en la que el rey Latinus entrega a Lavinia a Eneas, llama la atención la representación de un miembro de la Iglesia presenciando el acontecimiento: parece que bendice la unión que será la que le dé la tierra y la descendencia a Eneas. Al mismo tiempo, vemos el papel de la mujer medieval ligada a un hombre, bien su padre o su marido, a través de Lavinia que pasa de estar unida a Latinus a estarlo a Eneas. La imagen traduce la interpretación 
contextualizadora, en el sentido en el que la expone Garnier: "la description littéraire ne remplace en aucun cas la présence de l'image. Elle-même fruit d'une lecture, elle interprète l'oeuvre, quelque impartiale et objective qu'elle se veuille $138{ }^{»}$.

Sin duda, la presencia de un representante de la Iglesia contribuye a reforzar el carácter positivo de esta trama amorosa. Podemos decir que esta representación es totalmente invención del autor de la miniatura, ya que está ausente en el texto donde Latinus recibe y oye a los mensajeros mandados por Eneas, que es cuando decide entregar a su hija, tal y como lo establece la voluntad divina. El copista se vuelve a alejar deliberadamente del texto, realizando la miniatura según su interpretación: lo que "li dieu ont esgardé" está reemplazado por la presencia de la Iglesia; así obra en un sentido de desmitificación el autor de la miniatura:

\author{
«Moult par sui viex, si n'ay nul hoir \\ ne mais que sole une meschine, \\ une fille qu'a non Lavine; \\ je l'ay proumisse estre mon gré \\ et encontre ma volenté \\ a I Prince de cest paÿs, \\ il a non Turnuz li manchiz. \\ Ma mouillier veult qu'il ait mon regne

\section{Et ma fille Lavine a femme, mais sortiz est et destiné et tuit li dieu ont esgardé qu'I estranges hom l'avra de cui roial lignie istra.}

Por tant que je vous oy ci dire, Cuit je que ce yert vostre sire:

Li dieu veulent, ce m'est avis, 


\section{Qu'il ait la femme et le paÿs.}

(V.3307-3327)

En la primera miniatura se nos representa a la reina enviándole el mensaje a Turno para comunicarle la entrega de Lavinia a Eneas y la ruptura de su acuerdo. La oposición de la madre de Lavinia queda reflejada en esta segunda miniatura del díptico que resume la entrega de su hija a un extranjero. La representación de este pasaje de la novela refleja fielmente la temática estudiada, ya que la causa del enfrentamiento de Eneas y Turno reside en la promesa incumplida del rey Latinus. Una vez más Amor y Guerra son causa y consecuencia de un enfrentamiento:

Quant la dame ot moult ploré, son duel, son complaint demené, si apella I escuier de cui elle fist messagier.

Ses parolles li encharja,

Droit a Turnus les envoia

Et manda lui celeement

\section{Que ce seüst certainement}

\section{Que Latinus li guenchisoit}

Et sa fille li retolloit;

Porchaçast soy sanz demorance

Qu'il li tenist sa couvenance;

Au Troÿen mueve telle guerre

Que fors le mete de la terre.

(V.3474-3488)

En este caso, el miniaturista no efectúa ningún cambio con respecto a su fuente, sino que refuerza gráficamente a la escritura: realzando el papel de reina y su superioridad social, expuesta en la manera en la que el mensajero se arrodilla ante la madre de Lavinia, y remarcando los atributos como la corona y el trono donde está 
sentada la reina. Este díptico sintetiza el antagonismo amoroso que determina la trayectoria heróica de Eneas y la unión necesaria, sellada por el amor, para una nueva fundación, frente a una unión imposible sin amor, simbolizada por la madre de Lavinia. 


\subsection{EL AMOR EN LAS MINIATURAS DEL ROMAN DE TROIE}

Al abordar el análisis de las miniaturas en Troie, es importante recordar, como dice Jung que «le Roman de Troie est le récit de la destruction d'une ville, qui est emblème d'une civilisation fastueuse, et celui de la destruction des Grecs, lors de leur retour. Mais le Roman de Troie n'est pas un simple récit guerrier, car les événements guerriers n'occupent qu'un tiers du livre. Le reste se compose de descriptions, de scènes de conseil ou d'ambassades et d'histoires d'amour ${ }_{139}{ }^{\prime}$. Y es precisamente esta multitud de temas presentes en Troie la que nos ha permitido estudiar en nuestro trabajo no solo el tema de la guerra sino también el del amor, y sus representaciones.

Existen tres miniaturas relacionadas con las tramas amorosas presentes en Troie, aludiendo a las escenas principales. Encarnadas en forma de miniatura están las tramas de Jasón y Medea, que ofrecen dos representaciones: una que hace referencia al encuentro de Jasón y Medea y la otra a la conquista del vellocino, y la tercera, que alude al rapto de Helena, ya tratada en la página inicial de la novela de Troie, pero cuya repetición demuestra la importancia de la escena en la novela que acusa a Helena de ser causante de la guerra. 
Miniatura 3, Folio 47 "Ci devise comment Medea parle a Jason et a Herculés. Et comment li roi Oetes li fet bon sembant"

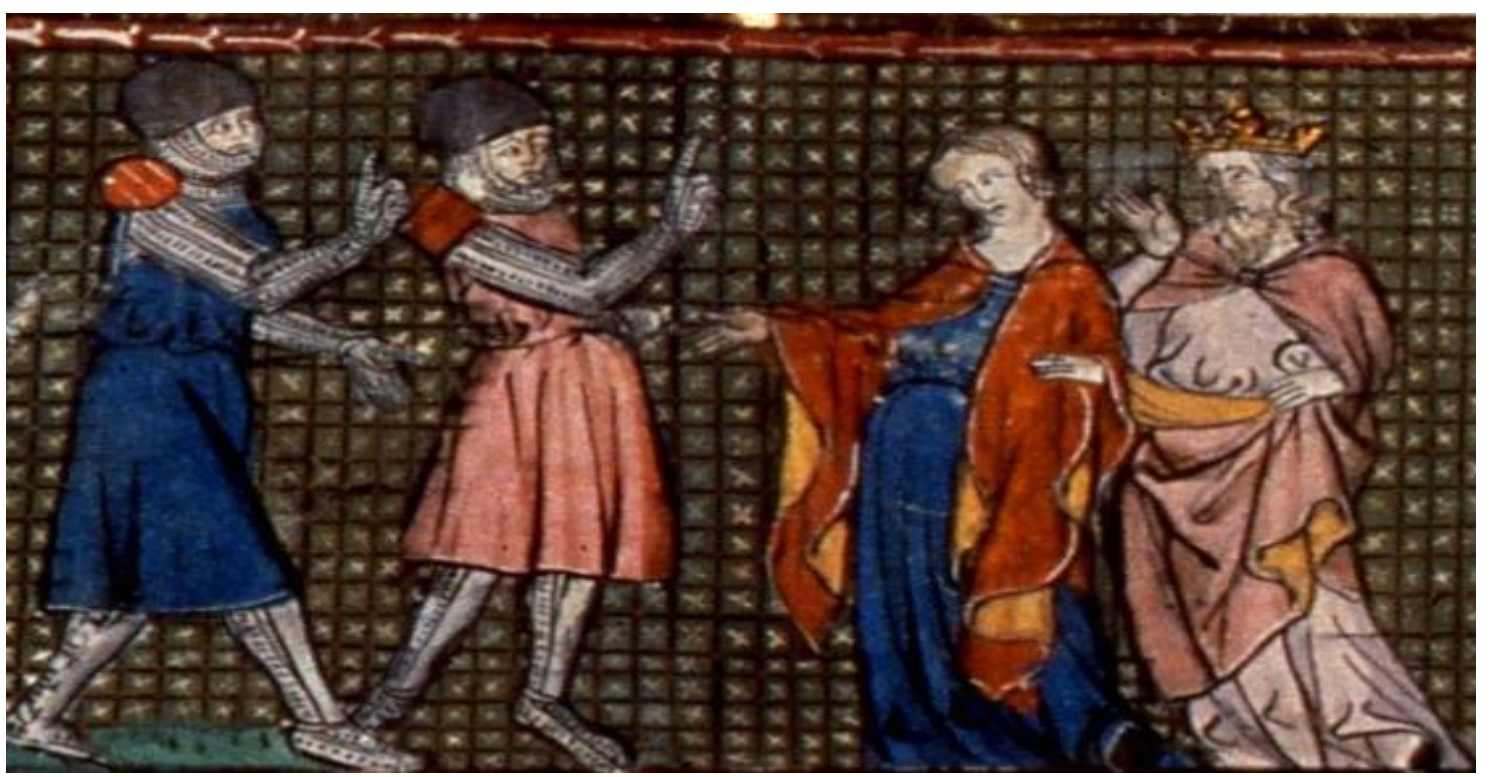

La primera miniatura en la que nos detendremos es la correspondiente a los amores de Jasón y Medea. En esta imagen, aparecen Jason y Hércules en presencia de Medea y su padre. Se representan dos de las clases en las que se dividía la sociedad medieval. A la izquierda, se sitúan Jasón y Hércules que forman parte de la clase guerrera, vestidos con la armadura y el yelmo, exponiendo una vez más los ideales de caballero por encima del hombre enamorado. Situados a la izquierda (siniestra), expresan el carácter negativo que van a tener para Medea y su padre.

En la parte derecha se aprecia a Medea en primera posición y, detrás, su padre que parece ofrecérsela a Jasón ya que será ella la que, en esta trama, tenga el papel principal y la que ayude a Jasón en su empresa. El papel de la mujer en la Edad Media aparece una vez más simbolizado en esta miniatura, en la actitud de sumisión de Medea ante los deseos de su padre y de Jasón. Hace referencia directamente al siguiente fragmento de la novela, a partir del cual podemos ver la variación de la miniatura:

Un jor, quant vint enprés mengier,

Si l'ot li reis a sei mandee 
En la sale pavimentee.

Assez la joïst e enbrace:

Cent feiz li a baisié la face.

\section{Comande li e dit aprés}

Qu'on Jason e o Herculés

Parout por bien, ce li consent.

(V.1300-1310)

En efecto, el miniaturista une dos escenas que aparecen de forma separada en la novela: por una parte, el momento en el que el padre de Medea manda a su hija a hablar con Jason y Hércules y por otra, la conversación de Medea y los dos hombres. En el texto la escena sucede sin la presencia del padre de Medea, por lo que apreciamos una variación en la interpretación del texto, quizás debido a la mala imagen de una mujer a solas con dos hombres, tal y como lo manifiesta la propia Medea en el texto escrito. Esta afirmación de Medea es la que hace que se reinterprete la escena según la mentalidad cristiana medieval:

Li dist: "Vassaut, ne tenez mie

A mauvestié n'a legerie

Se a vos me vieng acointier.

Il ne vos deit pas enuier.

Dreiz est e biens, ce m'est avis,

Qui home veit d'autre païs,

Qu'il l'aparout e araisont

E que leial conseil li doint.

(V.1313-1320)

Al mismo tiempo, esta miniatura evidencia otro rasgo tradicional: la mujer siempre unida a un hombre. Recordemos que la única miniatura en la que aparece una mujer como principal protagonista es la miniatura del suicidio de Dido, escena clave 
consecuencia del abandono de su amado, que también justifica, de cierta manera, la dependencia de las mujeres a los hombres en la Edad Media.

Miniatura 4 y 5, Folio 49: Ci devise comment Jason ala en l'ille de Colchos pour avoir la Poison d'or. Et devise comment il se combati au serpent.

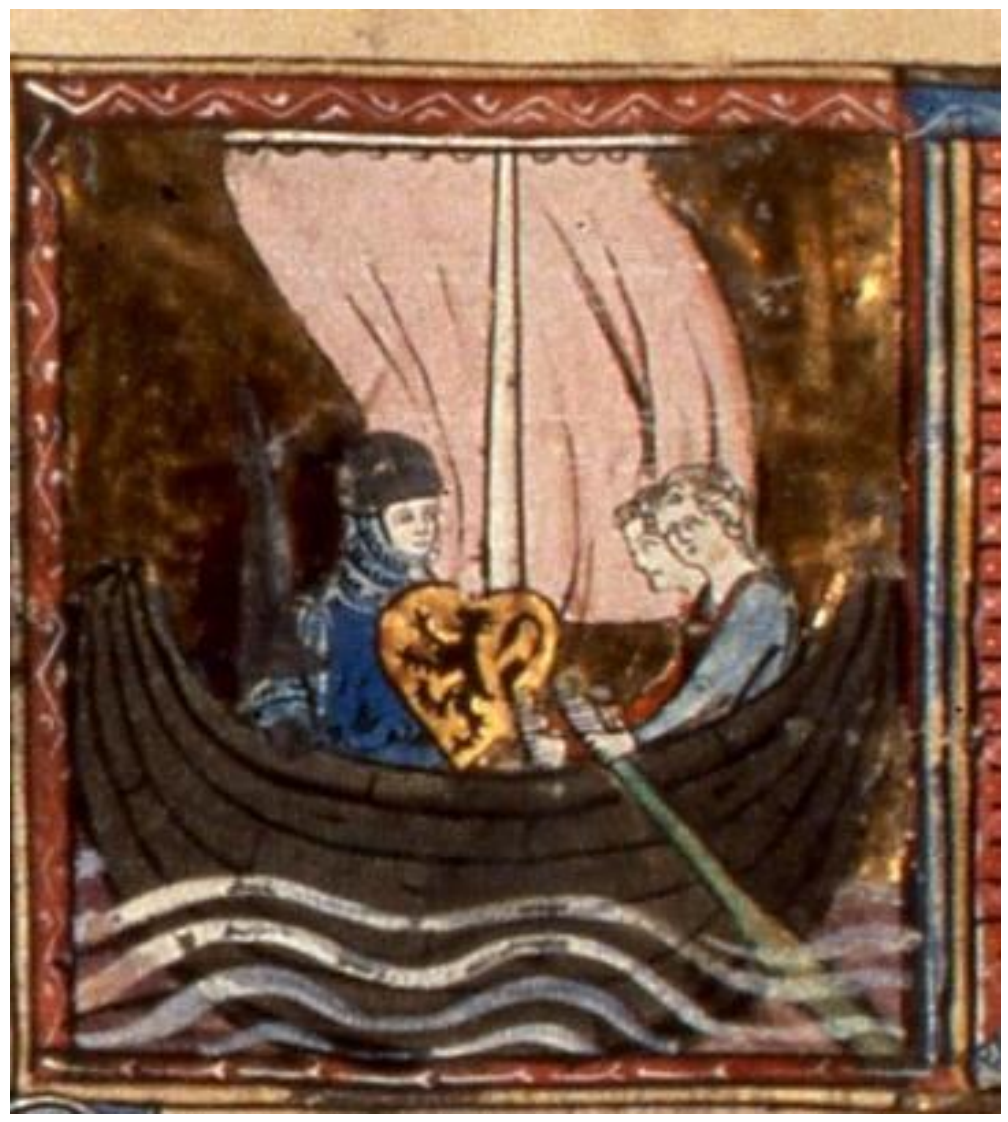




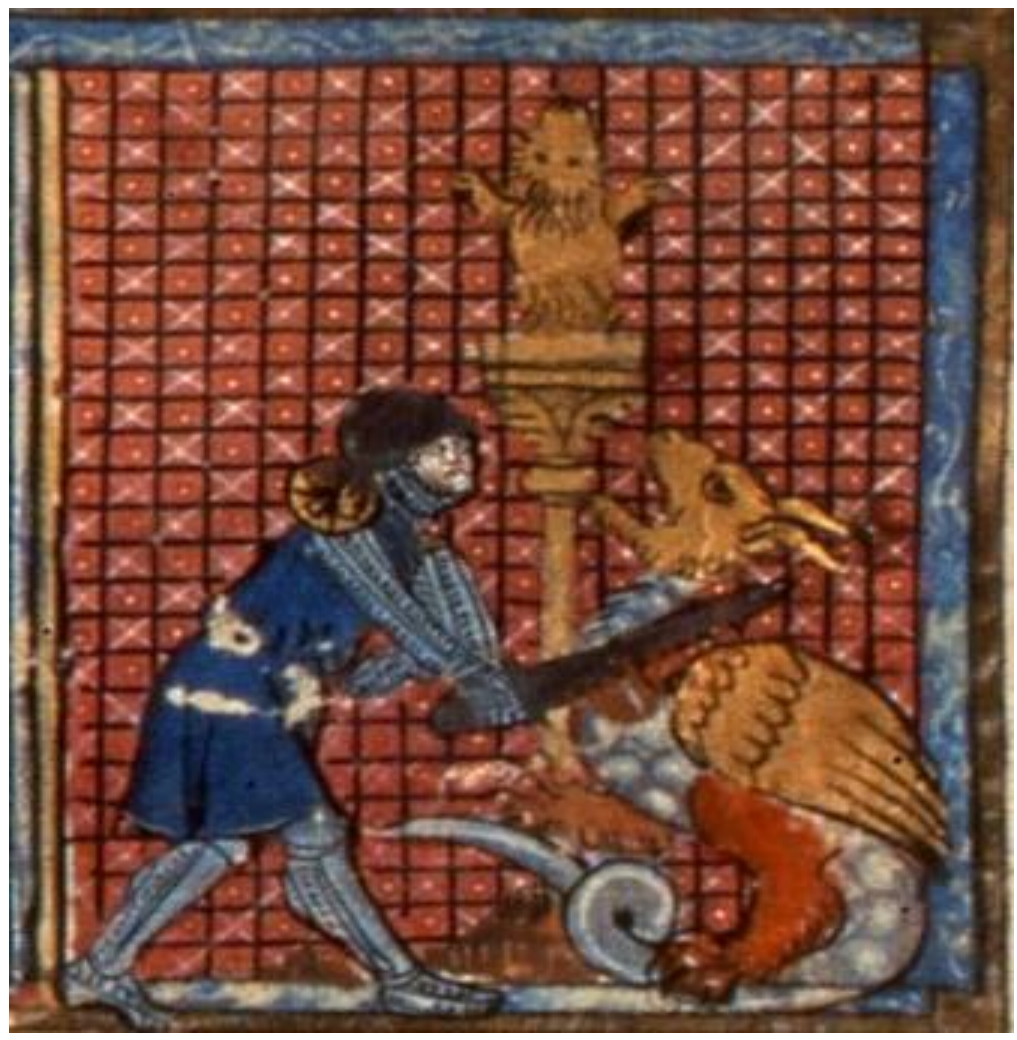

En el díptico vemos a Jason viajando con sus vasallos. Aparece como protagonista de la escena, tal y como lo describe Benoît de Sainte- Maure: vestido de caballero y con el escudo, como lo suele representar el miniaturista; la segunda miniatura, relacionada con la trama amorosa de Jasón y Medea, aparece ya expuesta en la página inicial de la novela de Troie. Corresponde a la escena principal: la lucha de Jasón con el dragón que guarda el vellocino, bajo la presencia de la estatua de Marte, dios de la guerra. La repetición de esta escena marca su carácter destacado tanto dentro de la novela como en el imaginario medieval: en la representación de los dioses como simples estatuas desprovistas de cualquier caracterización, y en la exposición del ideal de caballero en la figura de Jasón, guiado por su mentalidad de caballero: lucha por sus fines y los consigue, tal y como lo hemos expuesto en la primera parte de este trabajo.

Las dos miniaturas siguientes completan anecdóticamente la trama amorosa de Jasón y Medea y las alusiones gráficas al vellocino de oro. 
Miniatura 6, Folio 59: Ci devise comment Helaine fu ravie au temple en Gresce et comment cil de Gresce furent destruit et mis a mort de dedens le temple

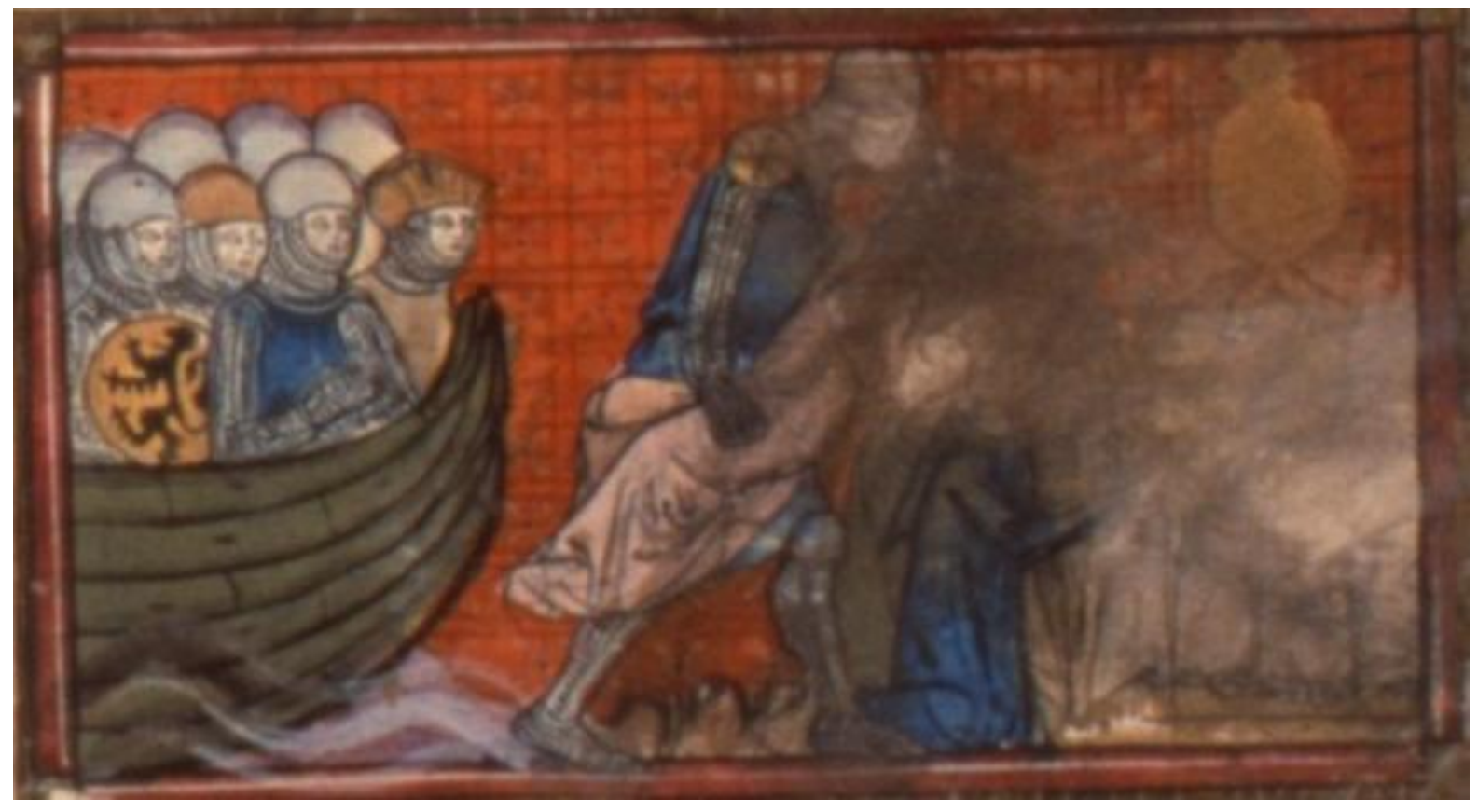

Otra de las miniaturas en Troie, relacionada con las tramas amorosas, es el secuestro de Helena, que también está plasmada en la página inicial del manuscrito, pero esta vez algo difuminada y deteriorada. Así todo, podemos ver el intento del autor por crear un hilo conductor confirmando la importancia que le otorga la novela. 
Miniatura 7, Folio 93: «Ci devise comment Troilus enmena la fille Calchas a Troie et comment li baron li font joie et comment son pere la revint querre mes il ne l'enmena pas»

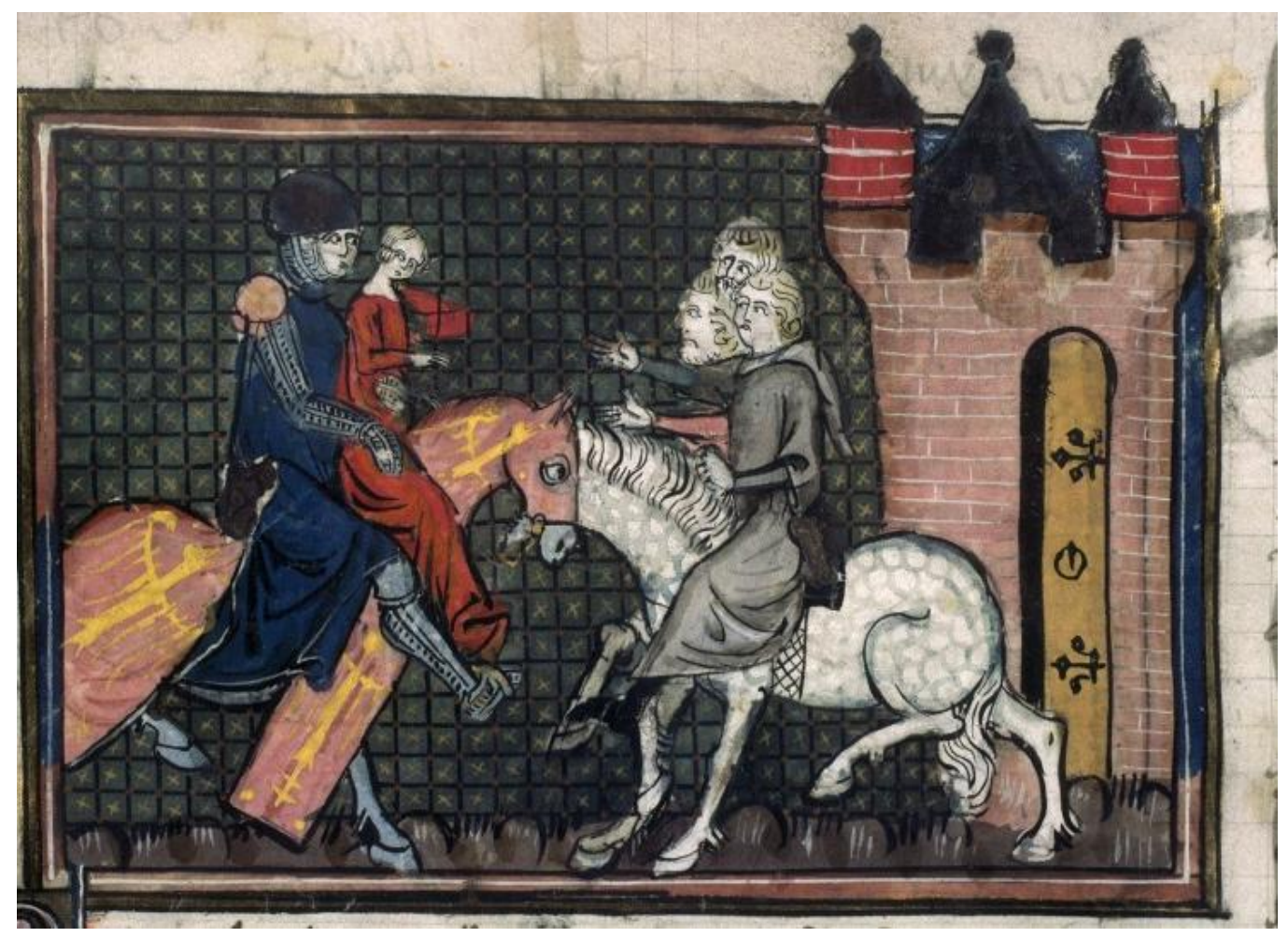

La última miniatura de este corpus hace referencia a la entrega de Policena hija de Príamo. Esta miniatura manifiesta indirectamente un episodio amoroso, los amores entre Troilo, Diómedes y Policena que tendrán una gran importancia en la novela y empiezan con la entrega de ésta a su padre.

Su observación confirma la interpretación positiva de los troyanos: situados a la derecha y desarmados, ofrecen una imagen de sumisión ante el guerrero griego que lleva a Policena a caballo. Las dimensiones de los personajes simbolizan la importancia del pasaje: la figura de Policena aparece en primer plano junto al guerrero griego, mientras que los troyanos, con las manos extendidas, simbolizan la acogida positiva de 
Policena, añadiendo una clara alusión a una de las funciones de la mujer en la Edad Media, como posesión del hombre.

Después de realizar el análisis de las miniaturas cuyo tema principal es el amor, nos damos cuenta no sólo de las variaciones que realiza el miniaturista con respecto a la obra medieval sino también de la proliferación de miniaturas amorosas correspondientes a Troie; comparándola con Enéas que sólo posee dos: un díptico que se centra en la trama amorosa que le otorgará su nuevo reino. El manuscrito de Troie representa tres tramas amorosas, dos de las cuales, Jasón y Medea, y Paris y Helena, ocupan efectivamente gran parte de la novela, entrelazándose con episodios guerreros. 


\subsection{LA GUERRA EN LAS MINIATURAS DEL ROMAN D'ENÉAS.}

Todas las miniaturas relacionadas con el tema de la guerra en Enéas hacen referencia a los momentos cumbres narrativos y no se detienen en combates secundarios ni en caballeros anónimos. Camila, por ejemplo, es omitida totalmente en las miniaturas, a pesar del gran peso que tiene en el texto, donde se le dedica más de mil versos. Esto puede significar que el miniaturista representa los episodios más acordes con la mentalidad medieval, omitiendo la representación de la figura guerrera femenina que choca con el ideal de caballero medieval.

Miniatura 8 y 9, Folio 165: «Conment Eneas prist les armes que Venus sa mere li envoia quant Vulcans les ot forgies. Et comment il se partid u Castel de Montalban. Et comment il ala querre secors a Pallantee et comment le roy li bailla sa gent et son filz pour lui recorre contre Turnus qui les avoit assis a Montalban»

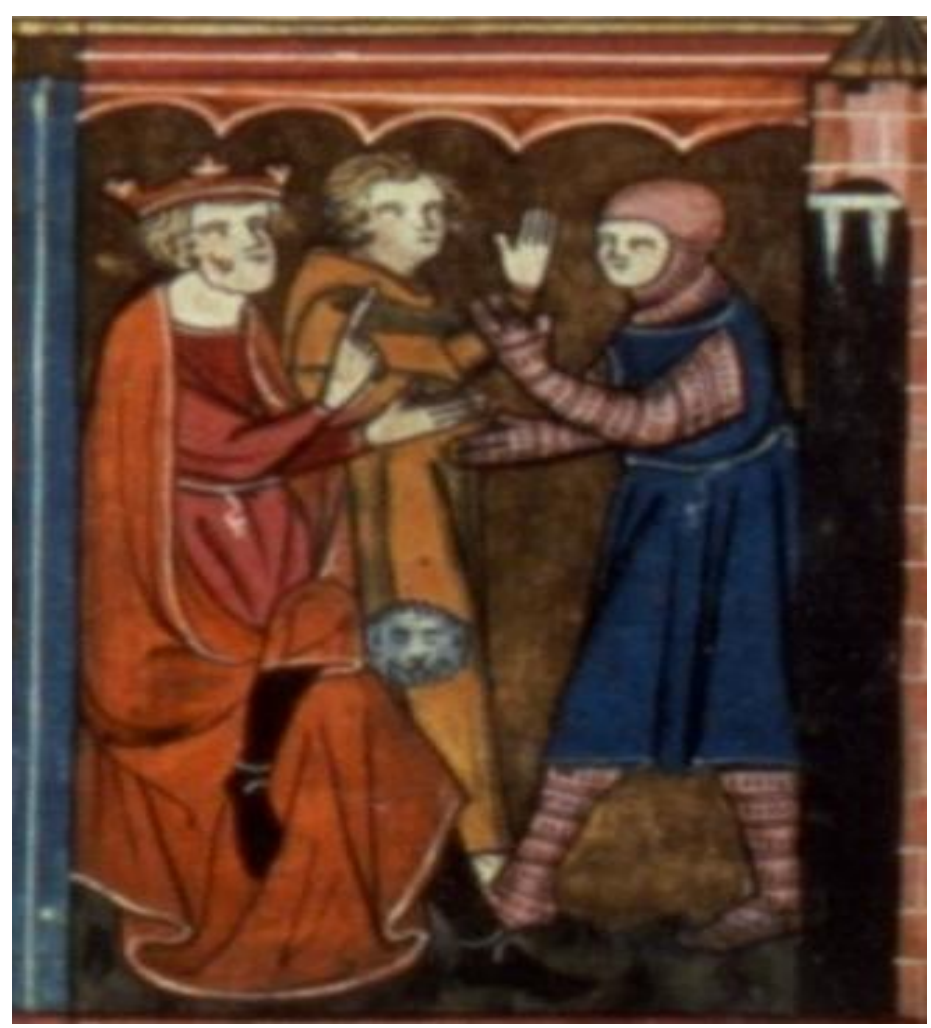




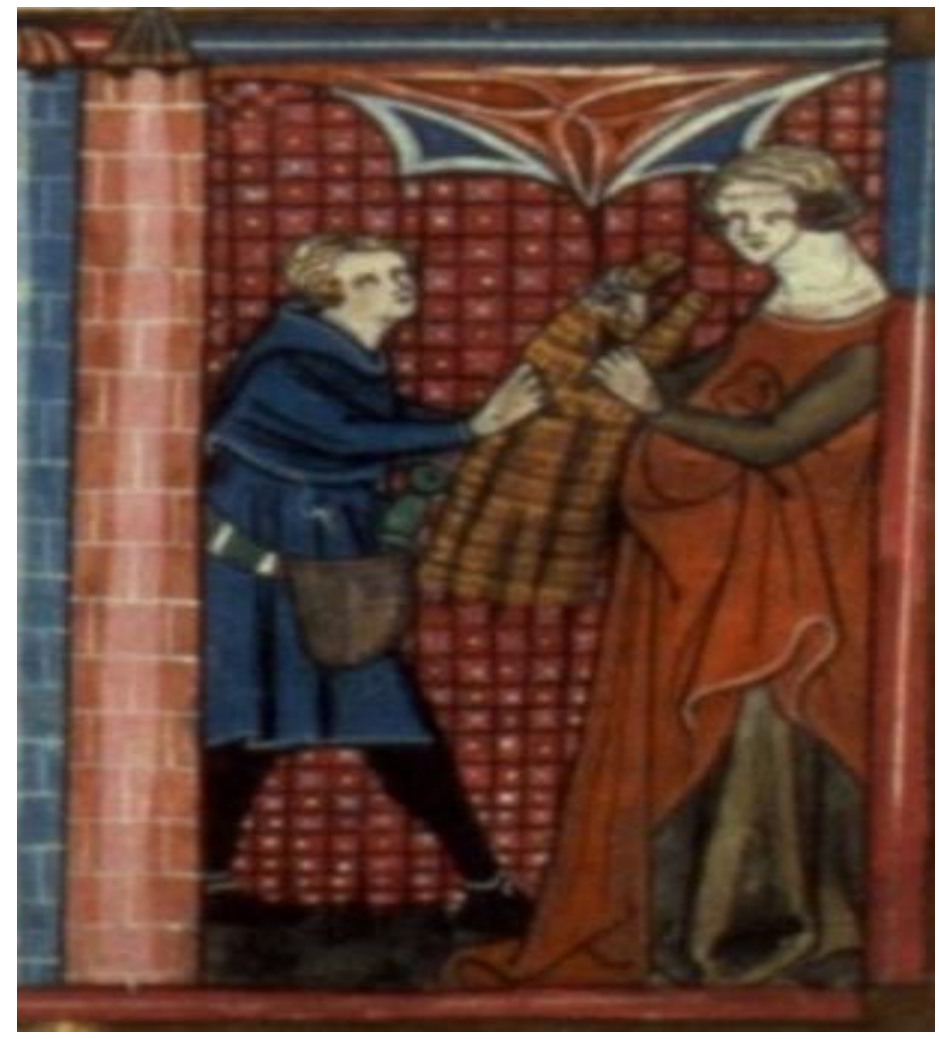

La primera miniatura del tema guerrero expuesta en la novela es la correspondiente a la etapa positiva de Eneas tras su partida de Cartago. Dividida en un díptico, nos presenta a Eneas pidiendo ayuda para el combate contra Turno. Pallas, uno de los personajes principales en la lucha, será representado en otra miniatura más. Vemos así cómo el miniaturista pretende dar importancia a los valores guerreros que posee este personaje ejemplar que muere en la batalla como un verdadero caballero. No olvidemos que el nombre de Pallas ${ }_{140}$ hace referencia a una divinidad griega que posee las mismas cualidades que este guerrero.

La otra parte del díptico nos muestra a Venus entregándole las armas a su hijo Eneas. Esta miniatura es la primera que muestra a una divinidad pagana con forma humana, a diferencia de las otras. Cabe destacar su representación:

140. «Pallas est, généralement, une épithète rituelle de la déesse Athéna, connue, très fréquemment, sous le nom de Pallas Athéna. Athéna était très souvent prise comme protectrice et patronne par les villes. À Troie, elle recevait un culte spécial, sous forme d'une très vieille idole, appelée Palladion. Cette idole était considérée comme la garantie de la survie de la ville. On ne pouvait prendre Troie que si l'on s'emparait d'abord de Palladion ». Grimal, P., Dictionnaire de la mythologie grecque et romaine / Pierre Grimal ; préface de Charles Picard, Paris, Presses Universitaire de France, 1976, p. 58, 340. 
Venus está caracterizada como una mujer que sobrepasa en tamaño a Eneas, y su ropa, asemejada a la vestimenta de la sociedad medieval, hace evidente el anacronismo dentro de la propia personificación. Su superioridad se refleja precisamente por su representación física, indicadora de la igualdad entre hombres y dioses y de la desmitificación ya realizada por el autor de la novela y continuada por el miniaturista. La miniatura hace referencia al siguiente pasaje que describe la actuación de Venus:

** Roman d'Enéas:

Quant Venus ot tot recëu,

Halberc et hialme et escu,

Chauces et lance et espee,

Et el l'ansoigne i ot fermee,

A son mesage les charja,

A Eneas les anvoia

A Montauban, ou il estoit.

Lo jor i vint li mes tot droit

Que Eneas s'aparoillot

Et del siege se conreot,

Et s'il venoit a grant destrece,

Qui garderoit la forterece.

Iluec li fu faiz li presenz

$$
\text { (..) }
$$

\section{Eneas a les armes prises}

Que sa mere li ot tramises,

N'est mervoille s'il les ama.

(V. 4543-4561)

Es importante destacar que en la adaptación medieval no es Venus la que entrega directamente las armas a su hijo sino un mensajero, lo que supone otra vez una 
variación en la representación de la miniatura. Sin embargo en la Eneida, sí que es la propia Venus quien entrega las armas a su hijo; de lo que se puede deducir que el miniaturista, conocedor de la versión medieval y de la fuente clásica, ha optado por esta representación, siguiendo, sin duda alguna, un criterio significativo en adecuación con un fin estético o didáctico.

Recordemos el texto antiguo:

** Eneida

"Pero la diosa Venus habia ya bajado a traerle sus dones, radiante de blancura, entre las nubes del cielo. Apenas desde lejos acierta a ver a su hijo en el fondo del valle, a solas en la orilla de la helada corriente, se dirige a él así y aparece resuelta ante sus ojos:

"Aquí tienes los dones ya acabados que prometió forjarte la destreza de mi esposo. Ya puedes hijo mio, sin recelo retar a los altivos laurentinos y hasta al brioso Turno.". Dice y tiende los brazos hacia su hijo la diosa de Citera y deposita las radiantes armas debajo de una encina en frente de él. Éste, gozoso con los dones de la diosa y con el alto honor, no acierta a saciar su alma de contento. $Y$ vuelve la mirada a cada pieza y se asombra a su vista y las toma en sus manos y sopesa en sus brazos el yelmo pavoroso con su penacho y su raudal de llamas, la espada portadora de la muerte, el duro coselete, forjado en bronce, de color de sangre, enorme, como grisácea nube que, embestida por los rayos del sol, arde y fulge su lumbre desde lejos 141 ".

Referente a la representación tan característica de esta divinidad, podemos explicarlo tal y como lo expone François Garnier: «La convention pratique par laquelle certains éléments figurés sont représentés plus grands que d'autres n'inclut aucune visée satirique et s'applique à tous les types de figurations sacrées et profanes. La grandeur des éléments peut correspondre à leur importance dans la représentation à un degré 
hiérarchique. Elle est un moyen d'exprimer la supériorité, l'égalité ou l'infériorité sur quelque plan que ce soit 142 ". En esta escena lo que se quiere representar es la superioridad de Venus frente a Eneas por la influencia del carácter divino frente al humano en una dimensión menos moral que artística, como rasgo propio de lo maravilloso medieval que se suele superponer a la escena mitológica.

Por otra parte, también podemos ver, en la representación de la entrega de armas a Eneas, cómo Venus salda su cuenta pendiente con Vulcano y a la vez presta ayuda a su hijo, dando un giro a su comportamiento como diosa del amor y regenerando su matrimonio, favoreciendo así la imagen positiva de la diosa/madre que nos pretende ofrecer el autor, al proyectar un ejemplo de conducta de la mujer medieval, dentro de la tercera función.

La otra miniatura, perteneciente a este díptico, pretende mostrar el momento en el que el rey entrega a su hijo para que ayude en la batalla a Eneas. Eneas aparece totalmente armado, vestido con la armadura de caballero y listo para la batalla, con las armas que, tal y como acabamos de ver en la primera miniatura, su madre le ha dado. En cambio, Pallas todavía no es caballero y, después de su entrevista, el padre lo armará caballero para que vaya a luchar con Eneas, siguiendo el texto de la novela:

Je sui viez hom, si remaindray,

Mais veez ci mon fiz Pallas

Que je moult aing: lui en menras;

Demain le feray Chevalier.

(V. 4842-4845)

En el análisis gestual de esta escena podemos destacar las actitudes del rey y de Eneas. A través de las posiciones de las manos la miniatura expresa la petición de ayuda

142. Garnier, F, Le langage de l'image au moyen âge: signification et grammaire des gestes, Tomo I, Paris, Le léopard d' or, 1982, p. 67. 
de Eneas y la entrega del rey Evandro de su hijo. Eneas, ya vestido de la armadura que le entrega su madre, solicita al joven Pallas representado sin armadura. Esta miniatura centra nuestra atención en la manera de simbolizar a una divinidad clásica, como ya hemos señalado anteriormente. La novela de Enéas en este manuscrito atenúa la presencia de las divinidades clásicas no sólo en el soporte escrito sino también en las miniaturas.

En los diferentes apartados de este trabajo hemos observado cómo el texto se distanciaba de la obra clásica en lo referente a la mitología clásica. Entonces ¿por qué la representación de Venus como una mujer medieval y no como una simple estatua? Hay que destacar el peso temático que tiene este personaje en la narración, ya no como diosa sino como madre del protagonista. Su presencia es indisociable de la trama textual y altamente significante: gracias a ella Dido acoge a Eneas y gracias a ella Eneas conseguirá su destino mediante las armas que ella le proporciona. Directa o indirectamente Venus tiene un papel fundamental en esta novela. Su representación como dama medieval, con la única diferencia de sus proporciones que aluden a su carácter divino, deja constancia del deseo no solo del escritor sino también del miniaturista de adaptar la novela clásica al mundo medieval.

La miniatura contribuye pues a la contextualización del personaje clásico y a su adaptación al género novelesco, insistiendo en la individualización de los personajes como se puede ver en las principales miniaturas estudiadas.

Miniaturas 10 y 11, Folio 171: «Comment Eneas en renvoi Pallas qui mors estoit, que Turnus avoit occis par devant Mont Alban en la compagnie des Troyens" 

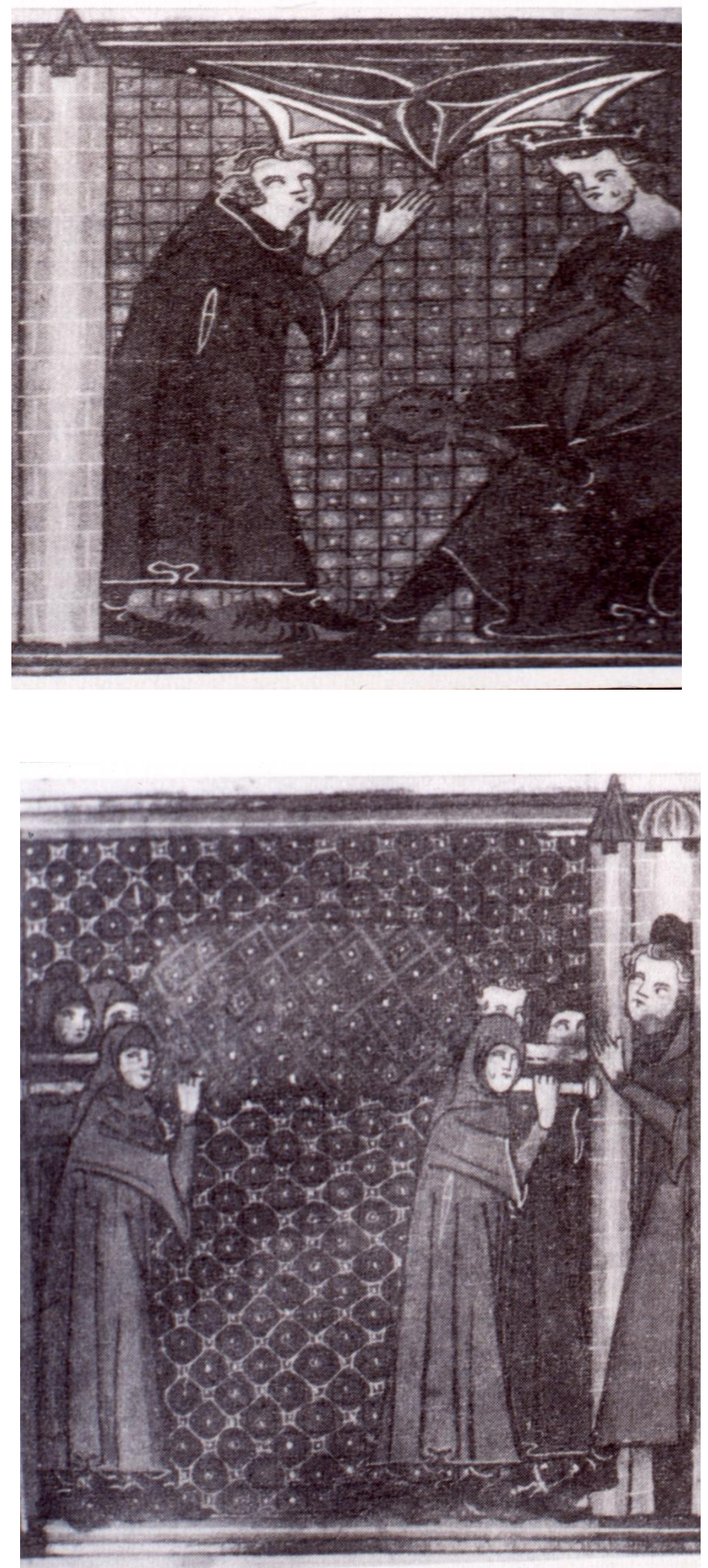
La miniatura número 10, según el orden establecido en el corpus, corresponde a la vuelta de Eneas a Pallantée y la entrega del cuerpo de Pallas. En este díptico hay que destacar los gestos de los protagonistas que explicitan la escena narrada por Benoît de Saint-Maure. La primera imagen nos presenta a Eneas conversando con el rey, exponiéndole la muerte de su hijo. El rey aparece sentado en el trono con gestos de dolor y las manos entrelazadas, mientras que Eneas aparece con una actitud que intenta demostrar súplicas, situado un poco por debajo del rey aunque el rey aparece sentado. Eneas ya no está vestido de caballero, mostrando así un sentimiento de culpa y de duelo ante la muerte de Pallas que consideraba su amigo más que un simple compañero de armas:

\footnotetext{
"Amis,fait il, ce est ramaje

Que vous estes por moy occis!

Amenay vous d'aultre paÿs,

Nostre amistié a poy duré,

Mauvais garant vous ay esté.

Venjerai vous se faire puis,

Mors est Turnuuz se or le truis."
}

(V. 5923-5929)

La miniatura número 11, que forma parte de este díptico, nos muestra el féretro de Pallas, llevado por varios hombres y, en una esquina, Eneas arrepentido por haberle causado la muerte. Del mismo modo que en la primera imagen es evidente en sus gestos y su actitud evidencian el dolor que siente tras la pérdida de su amigo y compañero de batalla. La descripción del cortejo fúnebre se aleja del texto para acercarse más aún a la mentalidad cristiana. Es que de nuevo, en este caso, la representación es totalmente invención del miniaturista, ya que, en la novela, Eneas no va en persona a entregar el cuerpo a la ciudad de Pallantée, sino que envía unos mensajeros para que se lo entreguen a sus padres. Sin embargo, el dolor de Eneas plasmado en las miniaturas, sí se ve reflejado en la novela en este pasaje, quizás en el que se inspira el miniaturista a la hora de realizar la miniatura: 
Au cuero moult de duel et d'ire,

Dessor le mort chaÿ pausmez;

Et quant il en fu relevez,

Le mort baisa tout en plorant.

La biere fist aler avant,

Adont les a mis a la voie,

Fors de son Castel les convoie.

Une grant lieue toute entière

Ala aprez euz a la biere;

Sa gent le firent arester,

Le mort laissa atant aler,

Et quant il vint au departir,

Maint plaint jeta et maint soupir.

Onques ne s'en voult retorner

Tant com les pot veoir errer.

Quant il em perdi la veüe,

A moult grant enviz se remue,

Retorna s'en a quelque paine,

Sa gent a Mont Alban en Maine.

(V. 6271-6289)

Tenemos que señalar que el díptico que acabamos de observar es omitido en los trabajos de Harf-Lancner que expone que el manuscrito contiene solamente 6 miniaturas en la novela de Enéas, cuando su estudio nos ha permitido comprobar que existen 7 miniaturas. 
Miniatura 12, Folio 170: «Conment Turnus occist Pallas et comment il entra en la nef et comment li vent l'emporterent par la mer».

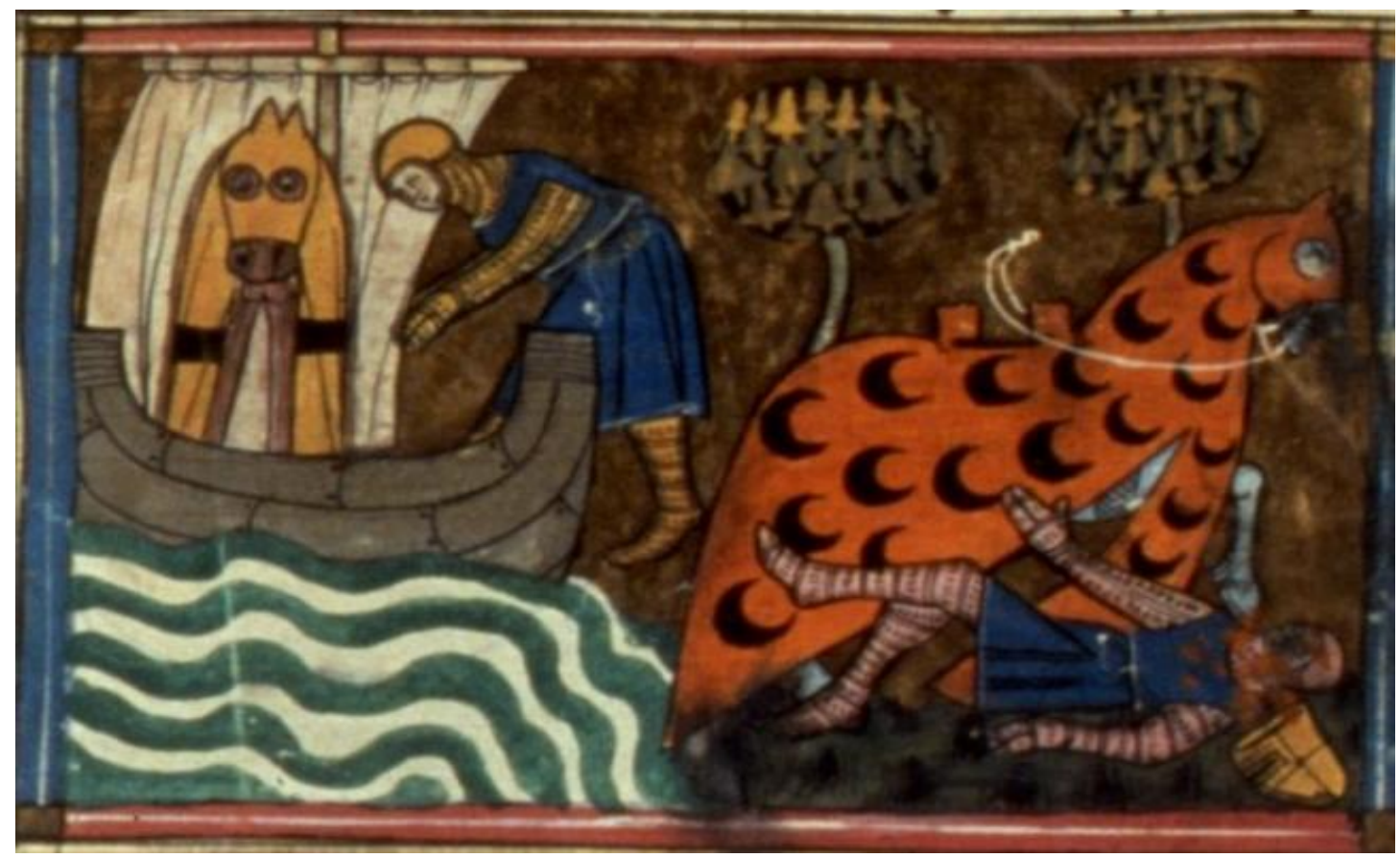

La miniatura número 12, está dividida en dos planos bien diferenciados, resaltando la importancia de un hecho frente al otro. En primer plano se encuentra Pallas herido en el suelo tras la lucha contra Turno, a su lado su caballo. En segundo plano está Turno intentando escapar por mar con su caballo en un barco. Llama la atención el espacio, esta vez exterior, en el que podemos ver dos núcleos de población a lo lejos, pudiendo representar la ciudad de Laurente.

Por otro lado, siguiendo con la configuración de la escena, vemos que Turno está situado a la izquierda, señalándose el carácter negativo de su actuación que desencadenará la ira de Eneas y provocará su propia muerte. Se omite el detalle que causará la muerte de Turno cuando se enfrenta con Eneas: el robo del anillo de 
Pallas $_{143}$, hecho muy significativo y detonante de la furia de Eneas. Curiosamente esta escena no ha sido seleccionada por el miniaturista; en cambio, insiste en los lazos de amistad que unían a los dos caballeros, al representar a Eneas en el entierro de Pallas, hecho ausente en la translatio medieval, exponiéndose sólo los sentimientos resultantes.

Las escenas que observamos en este apartado dedicado a la guerra están todas relacionadas con la lucha contra Turno, ya que esta lucha es significativa, al proporcionar a Eneas la tierra y a Lavinia. Es la que le permitirá alcanzar el ideal de caballero, perdido en la primera etapa de la novela tras la huida de Troya. Queda pues eludida cualquier representación de las amazonas y los combates secundarios, o hechos que no se refieran a la conquista de Laurente (por ejemplo, el episodio de Ascanio).

Al centrarse en Eneas y la lucha por el ideal de caballero, la miniatura le desmarca de su etapa negativa y evidencia la evolución del personaje: en su segunda etapa ya no se le representa con corona sino con la armadura, vestido de caballero en busca de su nuevo reino, siguiendo fielmente en este caso el texto de la novela escrita:

Il s'est couvert, hurter le vait;

\section{Tant roidement Pallas estait}

Qu'il ne remut por lui plain pié;

deceü l'a et engignié,

Dessouz l'auberc li a boutee

Par mi le cors toute l'espee.

Pallas cheï, qui navrez fu,

Gete l'espee, Laast l'escu;

Il souspira et souglouti,

L'ame du cors li departi.

Mors est, n'en puet mais chaloir

143. "Un anel choisist en son doi

Que Eneas lio t doné;

Molt i ot bon ancestané

Un lioncel fet d'un jagonce"

(V. 5763-5766) 
Qui que puisse la feme avoir.

Or l'aist Turnus ou Eneas,

Comparé l'a moult chiar Pallas.

Onc ne fu puis ne ainz cel jor

En Bataille ne en estor;

(V. $5816-5831)$

Miniatura 13, Folio 167: «Conment Nisus et son compaignon se murent du Castel de Montalban et conment il vindrent en l'ost quant tuit cil de l'ost furent endormi».

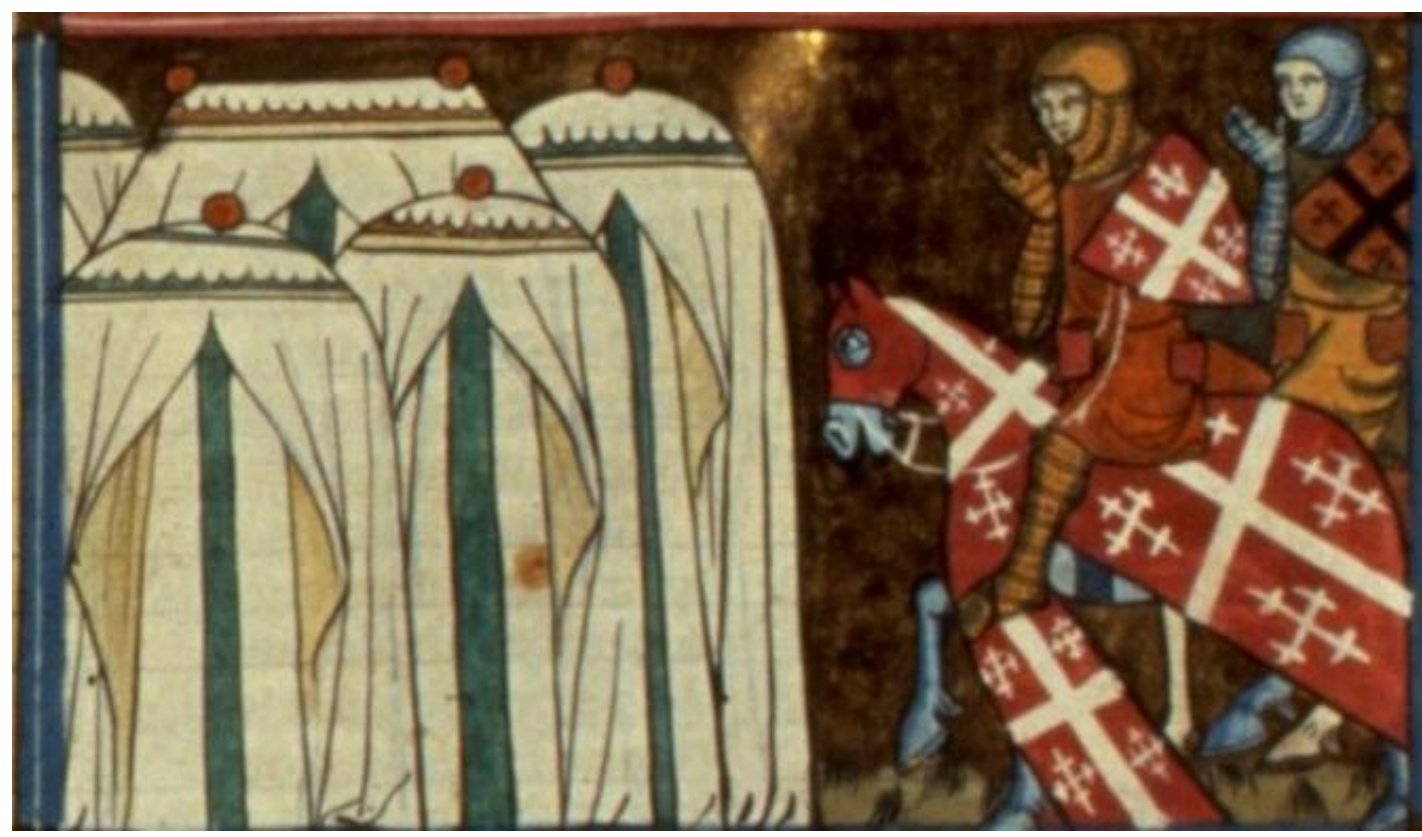


La penúltima miniatura de Enéas, que atañe al tema de la guerra, es la que nos muestra a dos de los compañeros de Eneas: Nisus y Euryalo. Estos dos guerreros tienen algo muy característico: son iguales y se profesan una gran amistad hasta morir el uno por el otro. Esta unión refleja la alianza entre Pallas y Eneas y justifica plenamente su representación por el miniaturista. En efecto, Nisus y Euryalo son los únicos caballeros secundarios presentes en las miniaturas aparte de Pallas. Esto es lo que nos dice la novela respecto a estos dos caballeros troyanos, haciendo hincapié en el valor tradicional de la amistad entre caballeros, al servicio de la causa. Valor humano y guerrero, vínculo que sólo desaparece con la muerte, cuya "valorisation $144 "$ se manifiesta tanto en el texto como en la miniatura correspondiente:

La cure ot du Castel sor toz,

Si avoit I sien compaignon, Euraiilus avoit non.

Amoient soy de tel amor

Qu'il ne povoient de greignor:

Onques plus vraie amor ne fu

Que d'euz tant co mil ont vescu;

L'un ne savoit sanz l'autre rien

Ne ne avoit joi ene bien.

A la porte la nuit veilloient,

Cil iI compaignon la gardoient.

(V. 4984-4998)

144. « En plus, la valorisation des éléments a posteriori laisse supposer la liberté d'usage à laquelle se prête l'œuvre esthétique, selon les différents contextes dans lesquels elle est reçue. Cette rétrospectivité du style explique la diversité des jugements proférés au sujet d'une œuvre, laquelle peut accéder, souvent longtemps après sa parution, au canon littéraire alors qu'elle en était jusque-là exclue. Le style a aussi pour fonction de véhiculer l'individualité », Poiana, P., « Figures et style : concepts esthétiques dans la théorie du discours de Gérard Genette », in Littérature, n 95, 1994, «Récit et rhétorique», p. 23-36. 
Miniatura 14, Folio 184: «Conment Eneas assailli la cité de Laurente et comment il se combati contre deux de la cité et bouta en la ville».

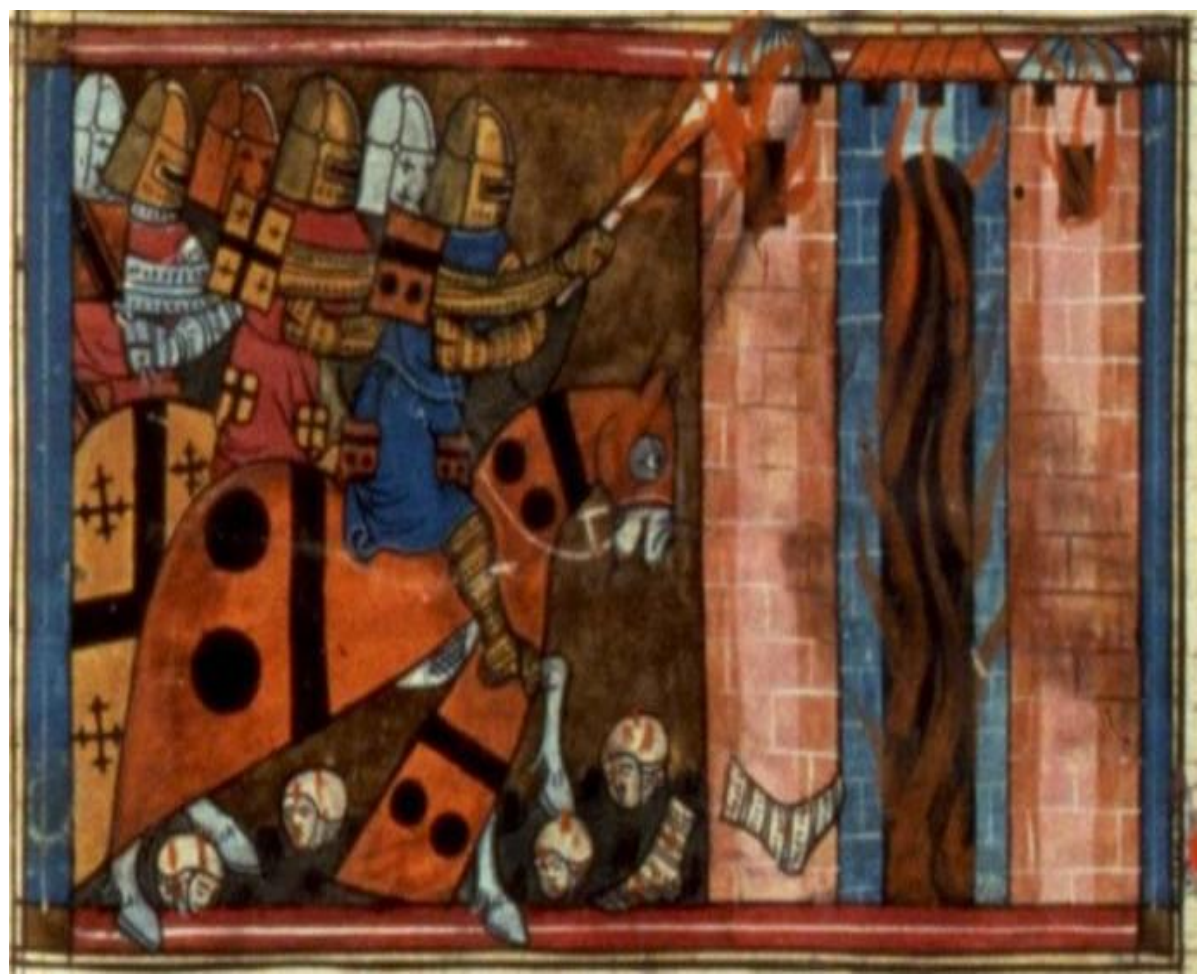

En la miniatura 14, apreciamos cómo Eneas lucha e invade la ciudad de Laurente; la importancia de esta batalla es clave para conseguir el reino prometido, de ahí la importancia que da el miniaturista a este acontecimiento, hasta en detalles escenográficos, tal y como se plasman en el texto:

** Laurente en flammes.

“Ainz que Eneas les assaille,

S'en voult l'une partie render,

Li autre se voudrent defendre;

coru sont aus portes fermer

Et vont dessor les murs monter, 
Nes voudrent point dedenz coillir.

Eneas les fait assaillir

Et fait a euz traire et lancier,

Et eschielles aus murs drecier.

Dont a le feu fait allumer

Et enaprés tout embraser,

Dont entendent au feu abatre

\section{Li citaien plus qu'a combatre,}

Que a defender la cité.

Cil deffors y fuissent entré

(V. 9664-9679)

Es como si las llamas que destruyeron Troya y le despojaron de su reino hacen que en este caso lo recupere, para crear un nuevo reino; al mismo tiempo que se purifica su figura de caballero, con el juego catártico se aleja el aspecto negativo de la primera etapa de Eneas. 
Miniatura 15, Folio 182: «Conment Eneas y Turnus se combatirent ensemble pour la fille au roy Latin au roy Latin et por la terre. Et comment Eneas le vainqui et l'ocist".

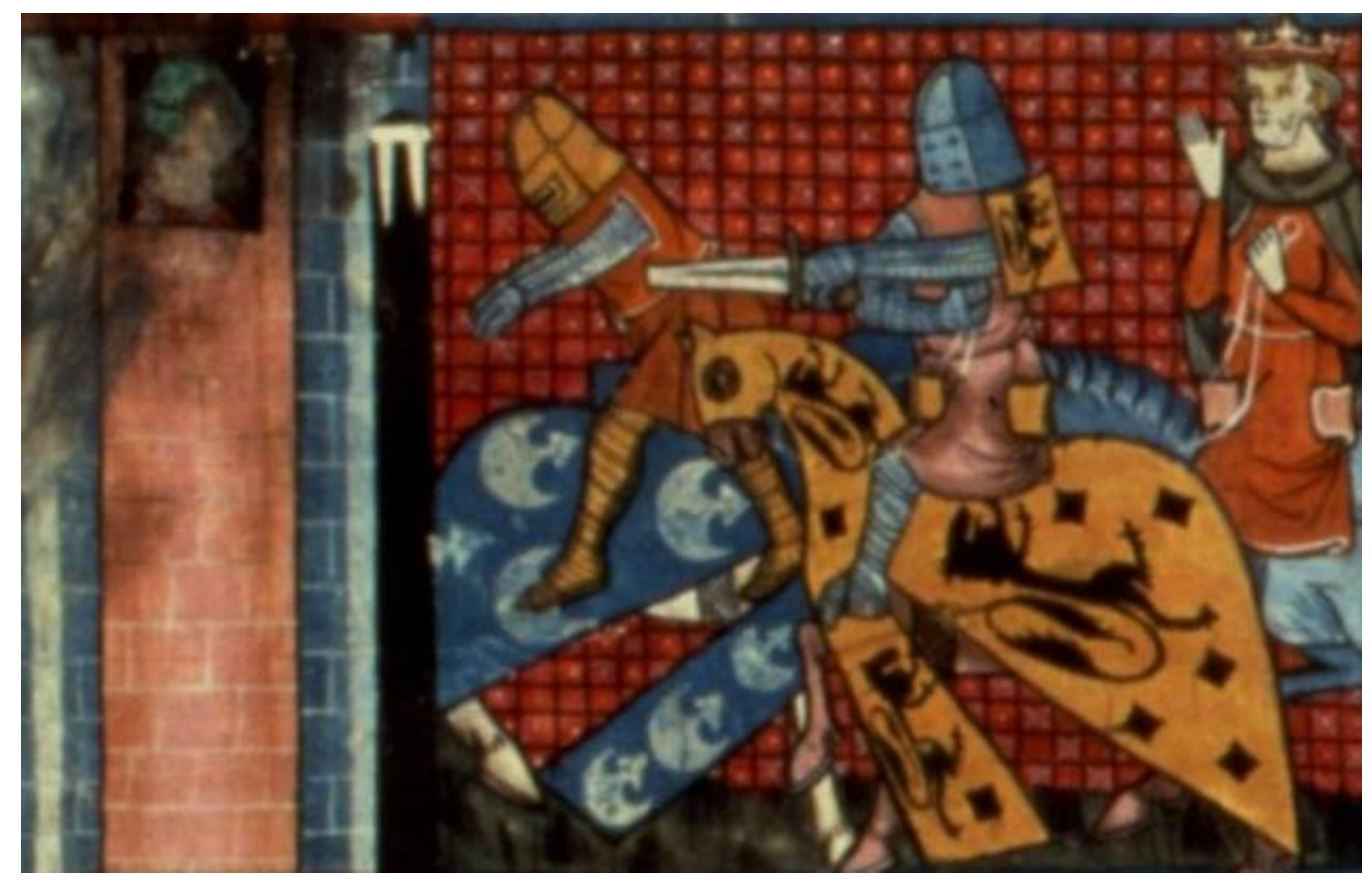

Esta miniatura es, con la anterior, la más destacada dentro de la temática guerrera, ilustrada por una simetría pictórica. Ambas reflejan los dos momentos claves: la lucha contra Turno como final del viaje iniciático de Eneas y su consolidación de caballero. Pues, tras la muerte de Turno, Lavinia y Laurente le pertenecen, habiéndolas obtenido a través de su lucha como caballero.

Así, la representación de Troya en llamas reflejada en la primera página del manuscrito, dentro de la primera etapa negativa de Eneas, queda solventada con la conquista de Laurente, también representada en llamas. Eneas cumple con su destino de fundador consiguiendo la tierra y la mujer prometida por los dioses, hilo conductor de la novela. Así lo resume la miniatura, con Lavinia en la torre del castillo y justo antes de que Eneas entre en Laurente y mate a Turno. Se ve a Lavinia en la ventana desde donde, según la novela, confesó su amor por Eneas. En esta asociación se plasma perfectamente la unión temática guerrera y la del amor, aludiendo directamente al episodio siguiente: 
Ne s'an savoit prou conseillier,

A la fenestre s'an rala,

Mist fors son chief, vers l'ost garda,

Et vit que Eneas venoit

Vers la cité, co mil soloit;

Ele an fu molt joiose et liee.

Il s'arestut une traitiee

Pres de la tor de l'autre part:

Por les tries n'i ot regart.

La damoiselle a lo brief pris,

Anviron la fleche l'a mis

D'une saiete barbelee;

La letre an a dedanz tornee,

$\mathrm{O}$ un fil estroit lo lia.

(V.8798-8811)

Esta última miniatura anuncia el desenlace de la segunda parte de la novela, reuniendo a los protagonistas: Eneas y Turno luchando, y al rey Latino situado en un plano secundario que aprueba con su presencia la transmisión del reino, junto con Lavinia como futura esposa de Eneas.

A pesar de la importancia narrativa que tiene Lavinia, no aparece en ninguna miniatura de manera individualizada; siempre aparece en un segundo plano que no concuerda con el contenido de la novela escrita en la que desempeña un papel principal. Sin duda se debe a la mayor importancia que el miniaturista presta al tema guerrero en Enéas, más espectacular en el plano pictórico. La temática amorosa, tan desarrollada en Enéas, parece pues accesoria, al servicio de su tema predilecto que es el de la guerra. 


\subsection{LA GUERRA EN LAS MINIATURAS DEL ROMAN DE TROIE}

La novela de Troya, en este manuscrito, es la más ilustrada en imágenes, y más concretamente en imágenes de guerra. Para su estudio, vamos a hacer una primera división entre las miniaturas que corresponden a la primera etapa (la trama de Jasón en busca del vellocino de oro) y las que atañen a la segunda etapa, referidas a la destrucción de Troya que se inicia con el rapto de Helena por Paris.

La primera miniatura de esta serie corresponde al Folio 44 miniatura número 16:

Miniatura 16, Folio 44: «Ci devise comment Pelues fist Jason venir devant lui et li dits qu'il last querre la Poison d'or, et comment il fist venir Argus devant lui pour faire les nez et les vésicaux pour aler par mer».

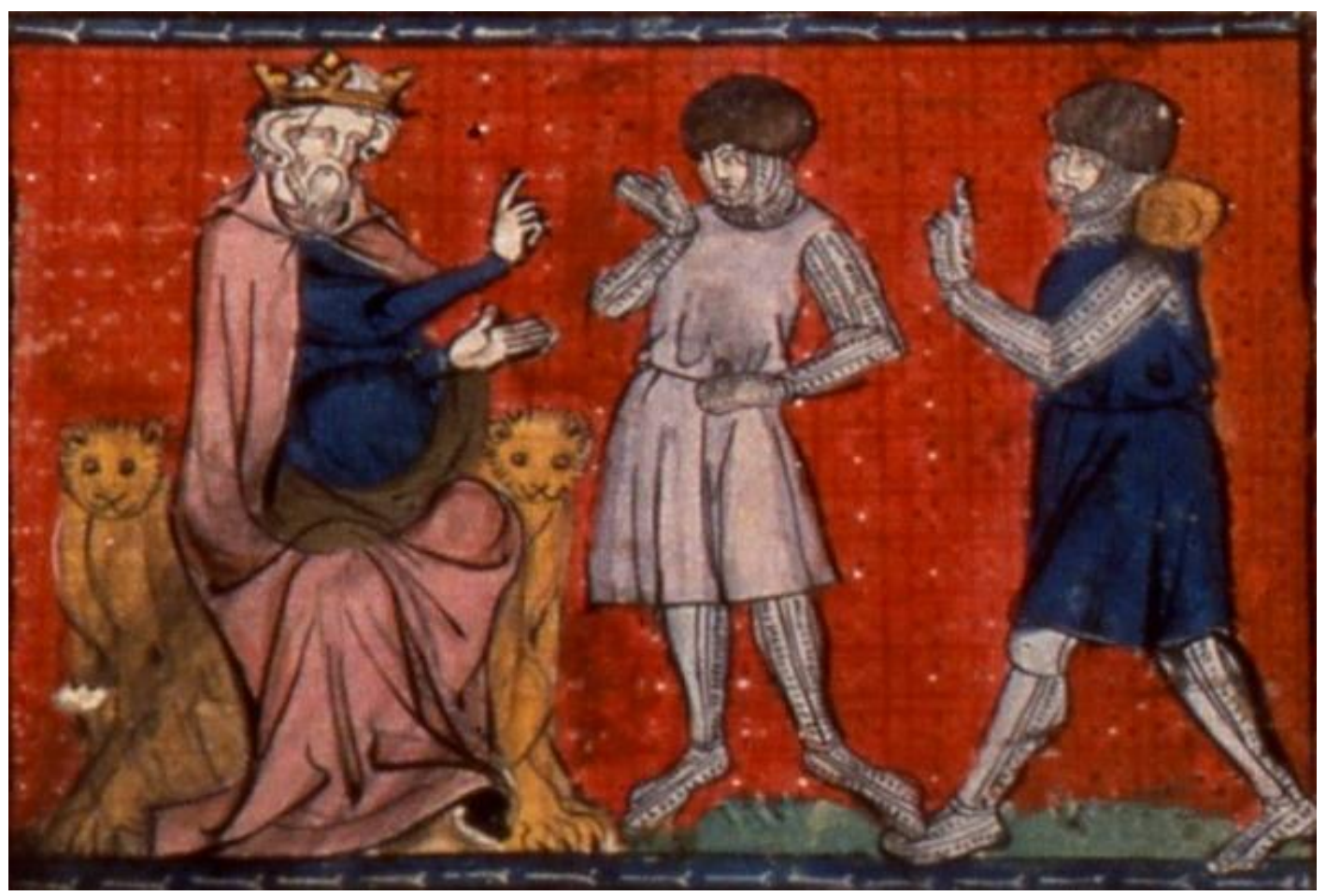


En esta miniatura, apreciamos a Jasón, Hércules y Peleo; corresponde al fragmento en el que el rey le hace la promesa a Jasón de que será el heredero de su reino si consigue el vellocino de oro. Aparecen Jasón y Hércules, como auténticos caballeros medievales vestidos para la lucha con sus armaduras y yelmos, y Peleo sentado en un trono adornado con dos leones, símbolos de la monarquía.

Por otra parte, las actitudes de los tres personajes son semejantes: Peleo y Jasón muestran sus manos de la misma forma con el dedo levantado. Podemos interpretar la posición como símbolo de autoridad ya que ambos personajes forman parte de las clases guerrera y monárquica, las que poseen el poder en la Edad Media; sin embargo, el gesto de Argus, encargado de realizar la nave para Jasón, es el de aceptación de la tarea que le encomienda Peleo. Esta miniatura corresponde al siguiente fragmento:

A guari se tient Peleüs.

Mander e querre fist Argus:

Engigners ert icil provez

Li plus tres saives qui fust nez;

Hom ne saveit soz ciel son per

Ne qu'ensi bien seüst ovrer.

Quant li reis l'ot a sei mandé, Prié li a e comandé

Que la nef seit faite e hastee,

Forz e siglanz e atornee

A endurer un fort tornent

E un orage e un gros vent.

(V. 893-904)

En este caso, el miniaturista no realiza ninguna variación respecto al texto, solamente caracteriza a los personajes según la clase social, explicitando gestualmente el significado del suceso que será causa y consecuencia del desenlace de la primera parte de Troie. 
Miniaturas 17 y 18, Folio 51: «Ci devise comment ceus de Gresce vindrent sus Troie la grant, et comment Laomedon le roy de Troie $\mathbf{i}$ fus ocis et Troie fu destruite et prise».
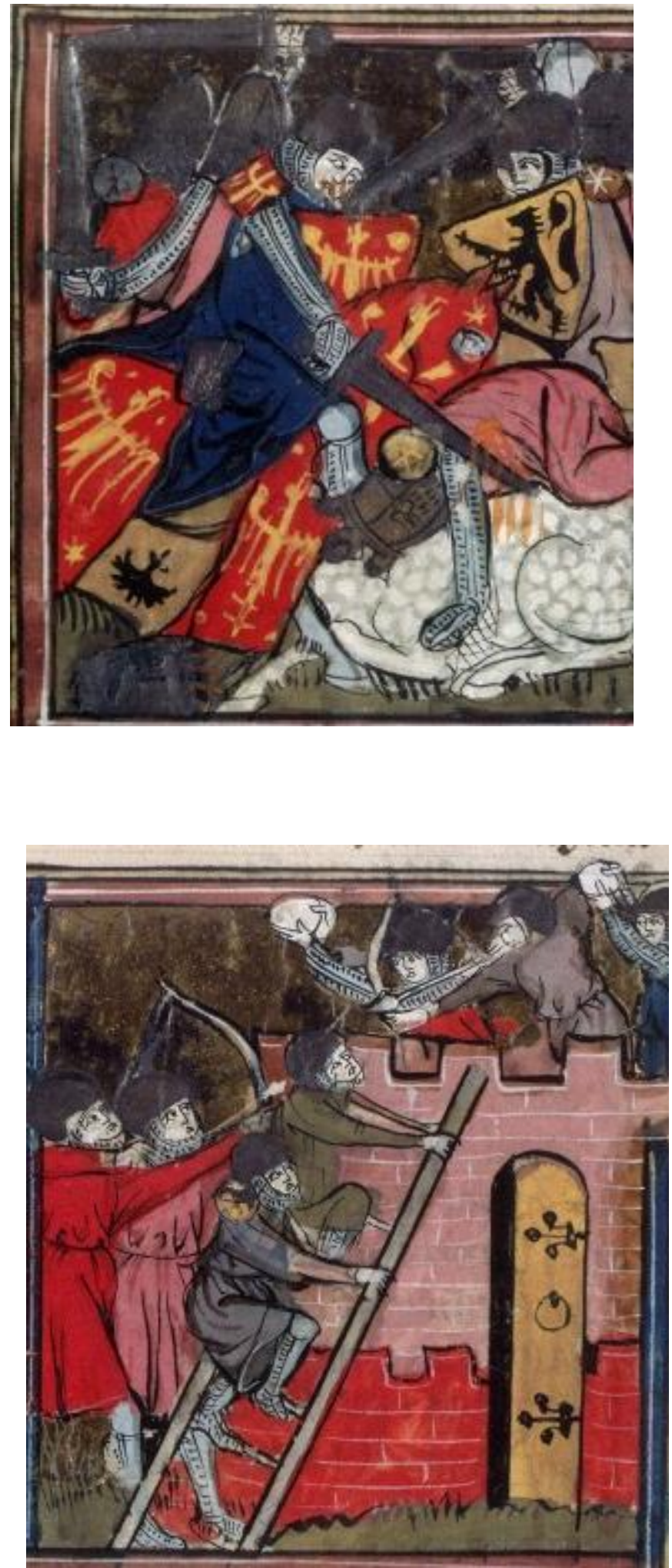
Estas miniaturas, número 17 y 18, representan la muerte de Laomedon y la primera conquista de Troya, muy brevemente descritas en la novela, que nos anuncia la destrucción de Troya, sin descripción de la batalla del primer desastre donde no sólo muere el padre de Príamo sino también la madre. Estas miniaturas reflejan unos pasajes del texto que son mencionados sólo a título recordatorio: el primer enfrentamiento entre griegos y troyanos se relata de forma muy indefinida en la novela, a modo de antecedente:

\footnotetext{
En ost esteit loing del païs,

Ou ses pere l'aveit tramis.

Un chastel aveit asegié,

Quant il li fu dit e noncié

Que Troie esteit e la contree

Arse e destruitë e robee,

E ses pere ocis e sa mere,

E ses serors e tuit si Frere,

Fors une dont iert grant damage,

Quin esteit menee en servage.
}

(V. 2867-2876)

En el pasaje siguiente, al que hace alusión la miniatura que, en este caso, es un claro ejemplo de las variaciones realizadas por el artista con respecto a la obra escrita, el autor insiste en el dolor que siente Príamo al enterarse del asalto a Troya y de la muerte de su familia. El miniaturista, en cambio, focaliza su atención en la batalla y la muerte de Laomedon:

Quant la novele fu seüe

E Priamus l'ot entendue,

S'il ot dolor, nus nel demant: 
Riens qui vesquist n'ot onc si grant.

Assez plora e fist grant duel;

Iluec vousist morir son vuel.

Mout a son pere regreté

E sa valor e sa bonté:

(V.2877-2884)

$* \quad * \quad * \quad * \quad * \quad * \quad * \quad * \quad * \quad *$

Miniatura 19 y 20, Folio 54: «Ci devise comment Troie la grant fu refaite, et comment li rois Prians tint son parlement et envoia ses mesages par tout».

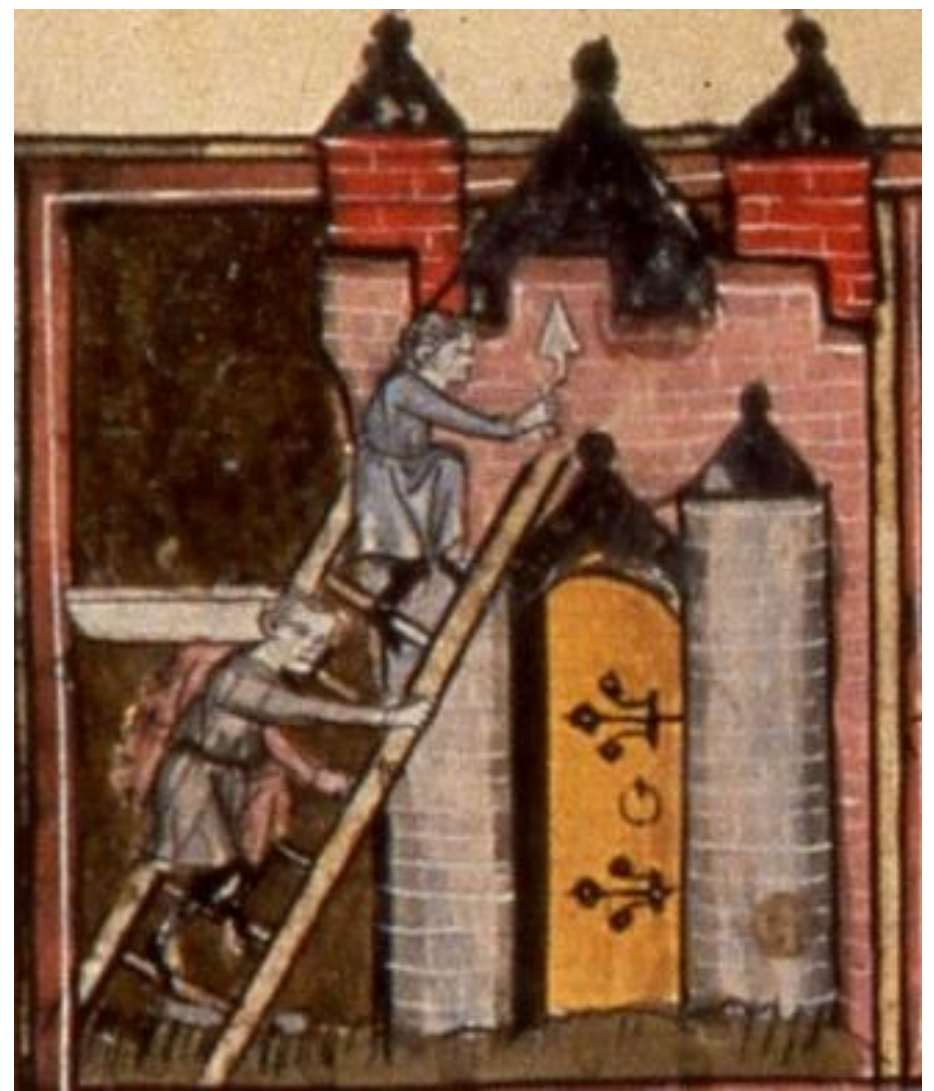




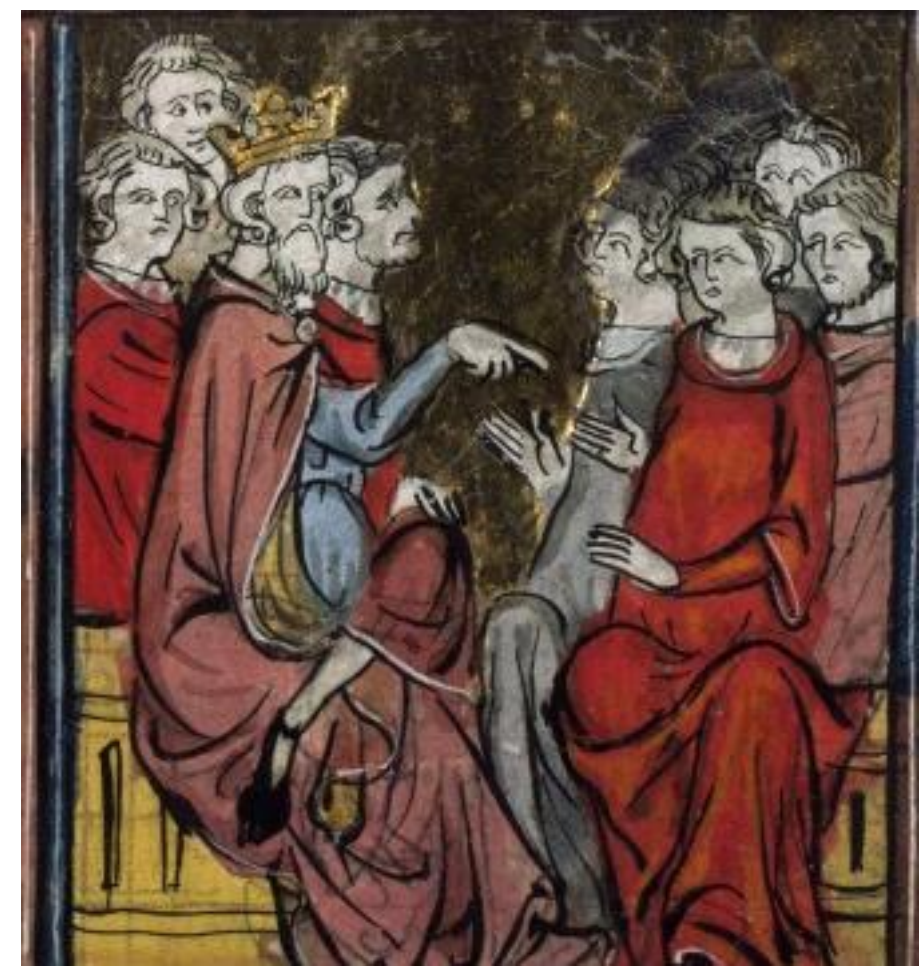

Las miniaturas 19 y 20 muestran la reconstrucción de Troya y el consejo de Príamo. Las miniaturas, temáticamente unidas, exponen una de las funciones de los caballeros feudales, la de dar consejo al rey: de esta forma aparece Príamo pidiendo consejo a sus vasallos sobre la reconstrucción de Troya. En la novela, este suceso motiva una extensa descripción en la que Troya representa la ciudad ideal, y en la que los trabajos de reconstrucción pasan a un segundo plano, escuetamente mencionados.

** Descripción de Troya después de la reconstrucción:

Ovrers quistrent, assez en orent,

E, a l'enceis qu'il onques porent,

Conmencierent le marbre a traire

E la cité tost a refaire.

Ce trovent bien li clerc lisant 
E encor est aparissant,

C'onques en terre n'ot cité

Qui la resenblast de biauté

Ne de grandor ne de largece

Ne de planté ne de richece.

Riche i sunt fait li fundement

E l'oevre qui de sus s'estent.

Mout la troverent degastee,

Mais cent tanz mielz l'ont restoree;

Mout la refirent bele et gente.

Mout i Mist Prianz grant entente:

Mout la fist clore de bons murs

De marbre, hauz, espés et durs.

Mout en erent haut li terrier,

Au meinz del trait a un archier.

(V. 2989-3008)

Tal y como describe Cartago el autor de Enéas, Benoît describe Troya como ciudad medieval, provista de murallas y construida con los más ricos materiales haciéndola ostentosa y soberbia.

En la miniatura correspondiente, el "grandor" se traduce por la altura explicitada por la escalera en la que trabajan los obreros. Igualmente, Harf-Lancner apunta la relación entre las miniaturas por la repetición de algún objeto como es el caso de la escalera utilizada para el asalto y también para la reconstrucción de la ciudad: «Il s'agit du premier conseil de Priam, qui décide d'envoyer Anténor demander aux Grecs la restitution de Hésion. Le jeu d'échos d'une miniature à l'autre est encore manifeste: le second tableau du diptyque précédent montrait l'assaut des Grecs qui escaladaient les remparts de Troie à l'aide d'une échelle. La même échelle ressurgit ici dans le premier tableau, appuyée contre la même muraille avec la même orientation; mais c'est maintenant l'échelle des maçons qui rebâtissent la ville. Quant au second tableau, le 
conseil de Priam, il sera repris presque trait pour trait dans la miniature suivante ${ }_{145 » .}$

En la segunda miniatura, aparece el rey Príamo llevando una corona, con el dedo apuntando a sus vasallos, actitud que indica la consulta del rey. Enfrente, los vasallos aceptando lo que les expone el rey con las manos extendidas. El rey Príamo es el único que aparece con rasgos bien diferenciados, representado con barba y apariencia de hombre mayor y sabio. Garnier expone que «les imagiers traduisent les caractères propres à chaque âge de deux façons: par des traits morphologiques et par des comportements. La barbe longue est le signe essentiel qui distingue le vieillard. Elle ne manque jamais ${ }_{146}{ }^{»}$

Miniatura 21 y 22, Folio 57: «Ci devise comment li rois Prians assembla i parlement de tous ses barons et sa gent. Et aprés devise com il alerent par mer en Gresce et comment Paris l'aseja premierement de nuis».

145. Garnier, F., Le langage de l'image au moyen âge: signification et grammaire des gestes, Tomo 2, Paris, Le léopard d'or, 1982, p. 88

146. Harf-Lancner, Laurence, «L'élaboration d'un cycle romanesque antique au XIIe siècle et sa mise en images: Le roman de Thèbes, Le roman de Troie et le roman d'Énéas dans le manuscrit BN français 60 », Le monde du roman grec. Actes du colloque international tenu à l'École normale supérieure, Paris 17-19 décembre 1987, éd. Marie-Françoise Baslez, Philippe Hoffmann et Monique Trédé, Paris, Presses de l'École normale supérieure (Études de littérature ancienne, 4), 1992, p. 302. 

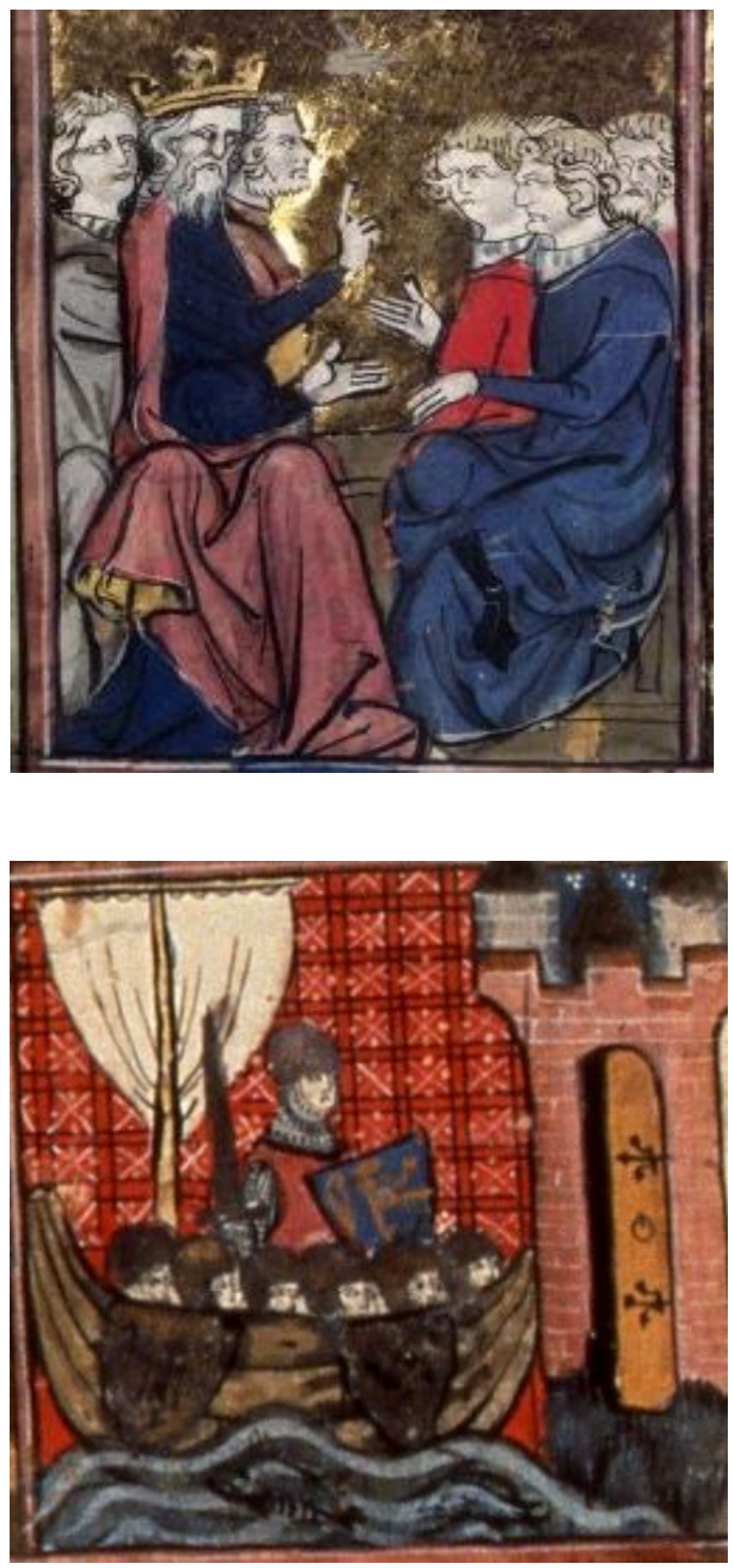
La miniatura 21, representa el segundo consejo de Príamo, esta vez con sus caballeros y el envío de Paris. Igual que en la miniatura anterior aparece Príamo rodeado de sus barones, esta vez, para encargarles vengar las ofensas que le han causado los griegos. Encontramos de nuevo el estereotipo en la actitud del rey que refleja la autoridad con el dedo apuntando hacia arriba, frente a la sumisión de sus barones.Como en la miniatura anterior, la figura del rey Príamo es la más destacada, quedando explícitos sus sentimientos e intenciones, tal y como lo recoge en el texto Benoît.

** Príamo reúne a sus hijos y sus hombres para exponerles las ofensas de los griegos:

De nos n'ont crieme ne dotance,

Mout prisent poi nostre poisance.

Ma seror ne me rendront mie.

Or ne sai je mais que je die,

Mais assez nos vient mieuz morir

Que ceste honte en paiz sofrir.

Dahé ait qui la soferra

E qui a tant ne s'en metra

Que l'on ne nos en blasme a tort!

A morir avons d'une mort:

Assez sovent a l'on veü

Que cil qui esteient vencu

Revenceient lur anemis,

Si qu'a elz erent puis sozmis.

Fort vile avons: jus qu'al juïse

Ne sereit ele a force prise!

Chevalerie avrons assez

E de gent a pié granz plentez;

Vivre e vitaille avrons adés. 
Mout nos devons metre a grant fes

Que de l'ire don't somes plain

Querons mecine a ester sain,

$O$ faire a celz honte e damage,

Qui le firent nostre lignage.

Serïons sain, lié e joios.

(V. 3665-3689)

Por otra parte, la miniatura 22 nos muestra a Paris en un barco a punto de llegar a la ciudad de los griegos, vestido de caballero con escudo y espada que señalan el enfrentamiento entre los troyanos y los griegos. Bajo él, en un segundo plano y muy poco diferenciados, ataviados con cascos, los demás guerreros. Así se valoriza su proeza tan explícita en la novela:

** Envío de Paris a Grecia

El tens que chantent li oisel,

Orent mer coie e le tens bel.

Les nés furent apareillees

E de la terre en mer lancees;

Vint e dous furent e non plus.

Mout lur venta dreit Eürus.

Li chevalier o les barons

Que Paris ot quis e semons

E sis frere Deïphebus

En Pannoine, trei mile e plus,

Furent venu d'armes garni,

Desfensable, prou e hardi:

En batailles ne en estors 
Ne poüst l'on trover meillors.

(V. 4167-4180)

* $\quad * \quad * \quad * \quad * \quad * \quad * \quad * \quad * \quad *$

Miniatura 23 y 24, Folio 63: «Ci devise comment les nés arriverent a Gresce, et touz les nons de ceus et de celles qui $i$ vindrent et comment il alerent a Apollo pour savoir le devin repons».

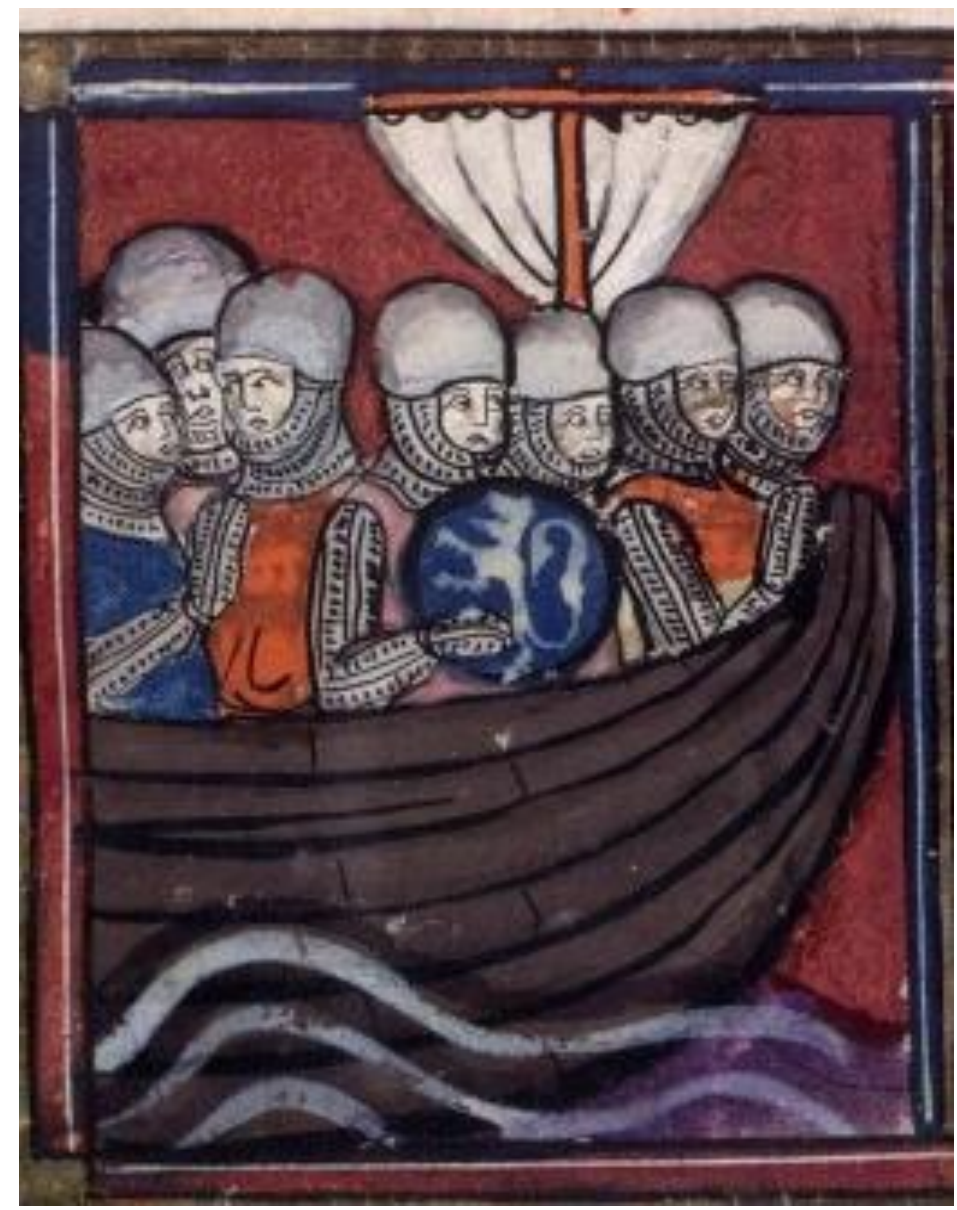




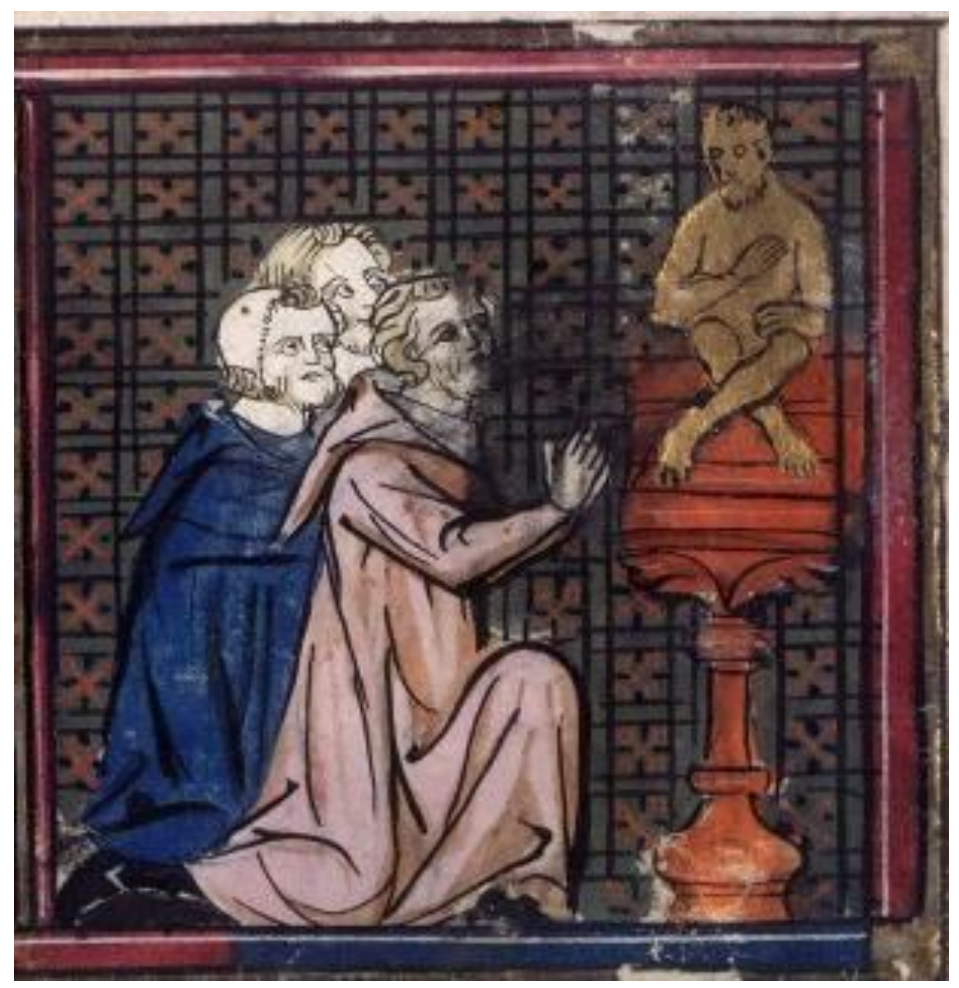

En las siguientes miniaturas podemos observar en un primer momento la representación del bestiario medieval con la presencia de un león en el escudo de Aquiles. El león es uno de los animales guardianes por excelencia. La forma leonina es también un recurso constante en la simbología política y la emblemática guerrera ${ }_{147}$. El escudo diferencia a Aquiles del resto de tripulantes dándole protagonismo en la miniatura. La segunda miniatura nos muestra consulta del oráculo. El miniaturista plasma nuevamente una divinidad clásica dentro de un marco gestual más bien cristiano: la genuflexión, ante el detalle arquitectónico del pilar.

«Qu'anceis que de ci meüssons,

A Apollo enveïssons

Prendre conseil de cest afaire,

Saveir a quel en porrons traire.

147. García, Fr., «El león» in Revista digital de iconografía medieval, vol.II, Madrid, 2009, p. 33. 
Li deus nos en dira bien veir

Senz faillir e senz deceveir.

Bon conseillier se fait a lui :

Quar bien sacheiz, si com jo cui,

Ja de rien puis ne doterons

Qu'il nos avra doné respons.

De ço nos est mout granz bosoinz,

Ne n'est mie Delfos si loinz

Que tost ne puissent repairier

Cil qu'i iront sacrefiier. »

(V. 5775-5780)

* $\quad * \quad * \quad * \quad * \quad * \quad * \quad * \quad * \quad * \quad * \quad *$

Miniatura 25, Folio 65: «Ci devise comment le roy de Gresce Agamennon envoia ses mesagers au roy Priant et devise comment il parlerent a lui, et aprés devise comment Troie fu assaillie second fois».

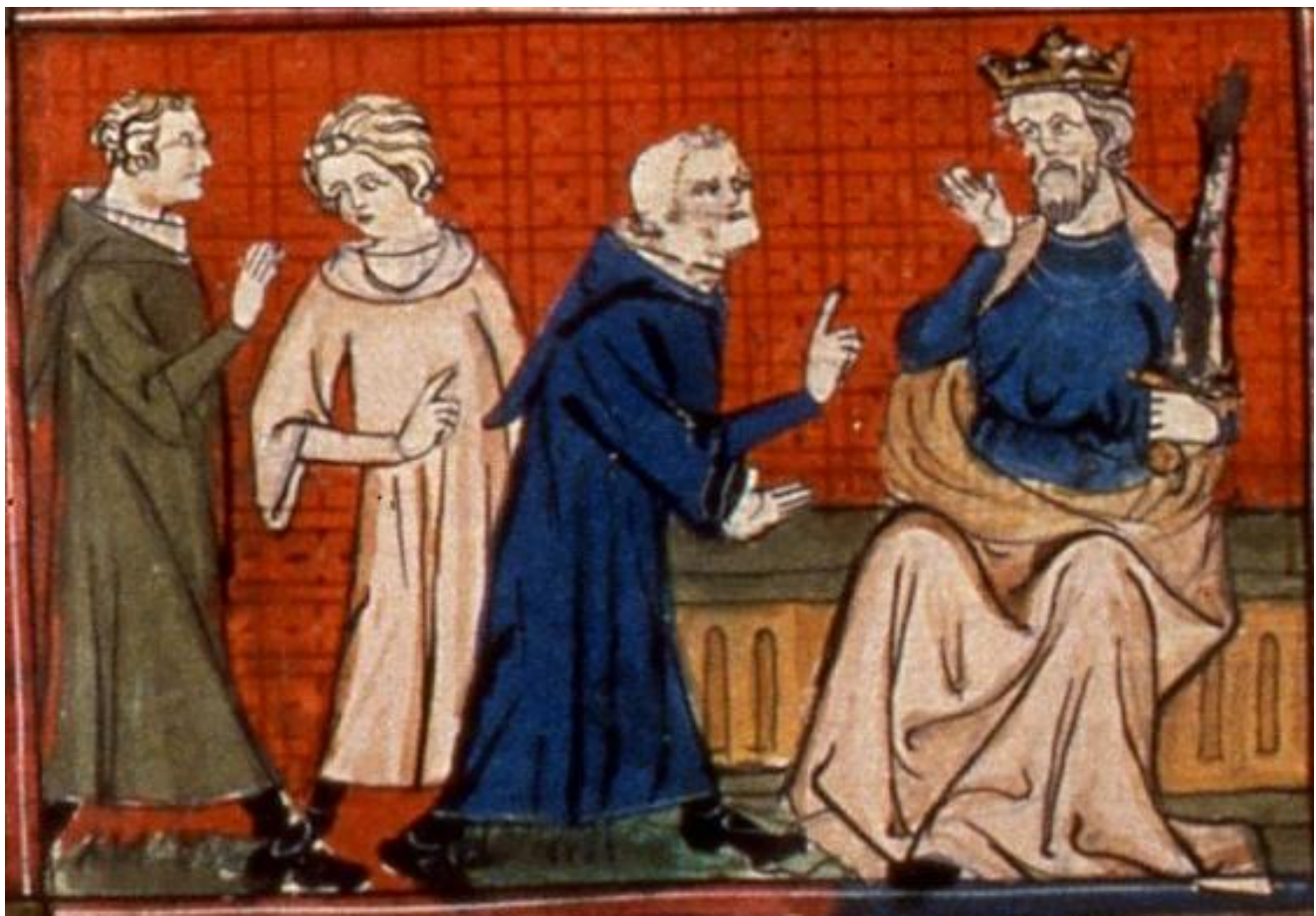


Esta miniatura nos vuelve a representar al rey Príamo, esta vez ante los mensajeros de Agamenón que reciben el mismo trato que Antenor a su llegada a Grecia, en el primer envío de mensajeros. Príamo aparece con la espada de guerrero que refleja la hostilidad de la entrevista, mientras el mensajero tiene el dedo levantado en señal de autoridad: la imagen muestra así el fracaso del envío de Agamenón, haciendo clara referencia al pasaje de Antenor:

Sacheiz grant l'avriëz conquis,

Se me rendiëz mort o pris.

La me cuit acointier a vos :

Se n'en avez l'eaume terros,

Ja puis armes ne porterai

N'en grant estor ne me verrai.

Ha! Quel vassal e quel baron!

Quin avreit treis en sa meison

Tant par se porreit faire liez :

Ja ne sereit desconseillez

De faire tost un hontos plait

Sire fait il al rei Priant,

Vostre respons ai bien oï.

(V.6461-6475) 
Miniatura 26, Folio 68: «Ci devise comment les Grieux venoient par mer a Troie. Et comment li Troien alerent contre eus es nés et se combatirent les uns contre les autres, et i en ot moult de noiéz des ij parties».

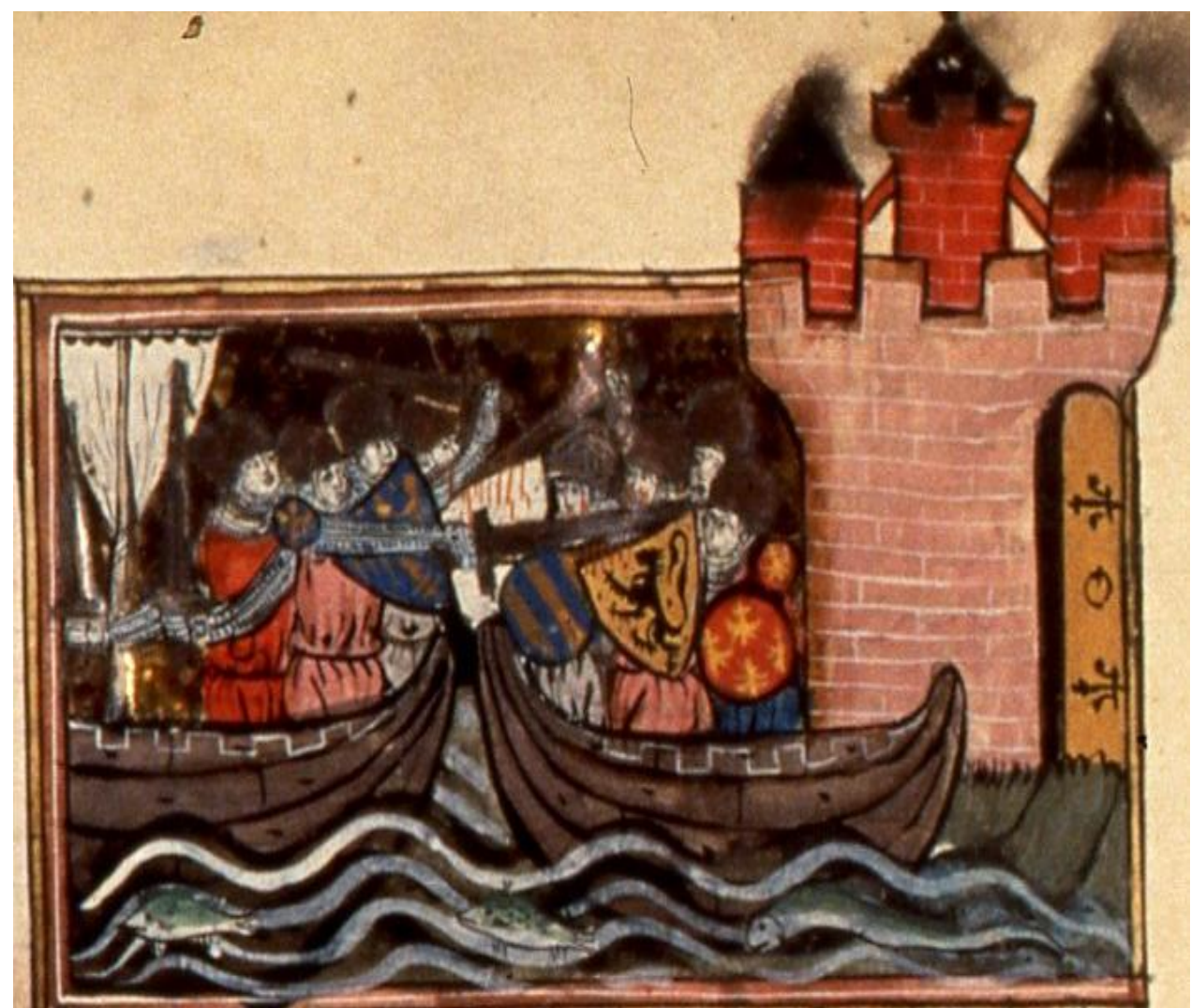

El contenido de la miniatura 26 es de total invención por parte del miniaturista ya que en la novela no existe ninguna batalla naval entre griegos y troyanos. Sobre esta miniatura, podemos decir, siguiendo a Harf-Lancner, que "Il arrive que la rubrique et la miniature soient en contradiction avec le roman. Ainsi dans le texte de Benoît, les Grecs sont assaillis, dès leur débarquement, par les Troyens qui leur livrent combat meurtrier sur le rivage. (...) Or l'image correspondante (Folio 68) représente une bataille navale, comme l'y engage la rubrique adjointe 148 ". Esta extrapolación se verifica en la obra de Benoît de Sainte-Maure donde no aparece ninguna batalla naval. En este caso la miniatura a modo de ampliación pretende enriquecer la narración, dando prueba de la imaginación de su autor. 
Las siguientes miniaturas que vamos a examinar reflejan tres de los episodios más destacados de la novela y de la temática guerrera. Estos acontecimientos son claves, ya que son desencadenantes de otros hechos secundarios relacionados con la trama principal: la destrucción de Troya a manos de los griegos. A su vez, ilustran los episodios protagonizados por Héctor; tanto en la novela como en las miniaturas Héctor se impone como personaje principal y representante del ideal de caballero medieval:

Miniatura 27: Héctor va a combatir contra los griegos.

Miniatura 28 y 29: duelo ante el cuerpo de Héctor.

Miniatura 30: ceremonia de aniversario de su muerte.

Miniatura 27, Folio 72: «Ci devise comment Priant li rois a ordoné ces batailles et comment il issent de Troie les eschielles ordenees les unes aprés les autres».

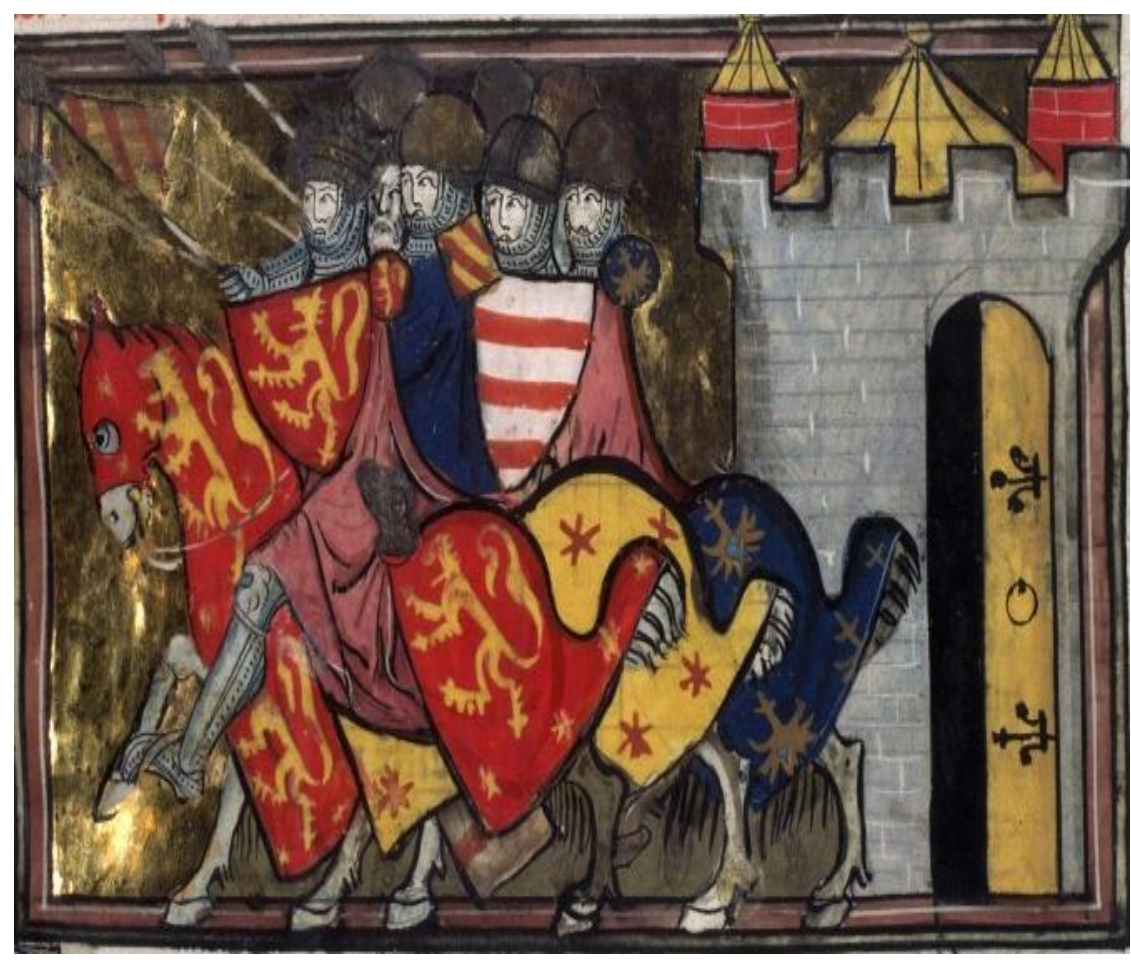


Esta miniatura representa, siguiendo el texto de Benoît, la escena en la que Héctor, vestido de caballero, se va a la batalla, acompañado de sus hombres:

\author{
Enz en la sale qui fu peinte \\ Monte el cheval, l'espee ceinte. \\ Son escu prent, puis si s'en ist. \\ De plus de mil fu aorez. \\ Molt ont grant joie receüe \\ Quant l'aperceit la genz menue. \\ Encontre lui vont tuit e corent \\ E de pitié braient e plorent.
}

(V. 16031-16044)

Una vez más, el anacronismo se evidencia en la representación de Héctor y sus vasallos como verdaderos caballeros medievales, listos para luchar. Recordemos la importancia del anacronismo que significa, según Aimé Petit, «l'impossibilité pour l'homme d'accomplir parfaitement la synthèse du passé et du présent, il représente en même temps une tentative pour échapper aux temps, mais c'est aussi l'objet d'une ingénieuse technique ${ }_{149}{ }^{»}$. Con respecto a la permanencia del anacronismo en la ilustración, podríamos decir que la miniatura, con la fijación de la imagen, modulada por el imaginario de la época en la que se realizó, atestigua el paso del tiempo, sintetizando el pasado y el presente.

149. Petit, A. L'Anachronisme dans les romans antiques du XII siècle, Paris, Honoré Champion, 2002, p. 286. 
Miniatura 28 y 29, Folio 79: «Ci devise comment Hector fu venus de la Bataille et comment il estoit navréz que ses suers lo desarmerent et comment il fu couchiéz en i lit et li lava l'en ses plaies et comment sa mere et sa femme et ses suers font duel devant lui, et son pere le roy Priant le vint veoir».
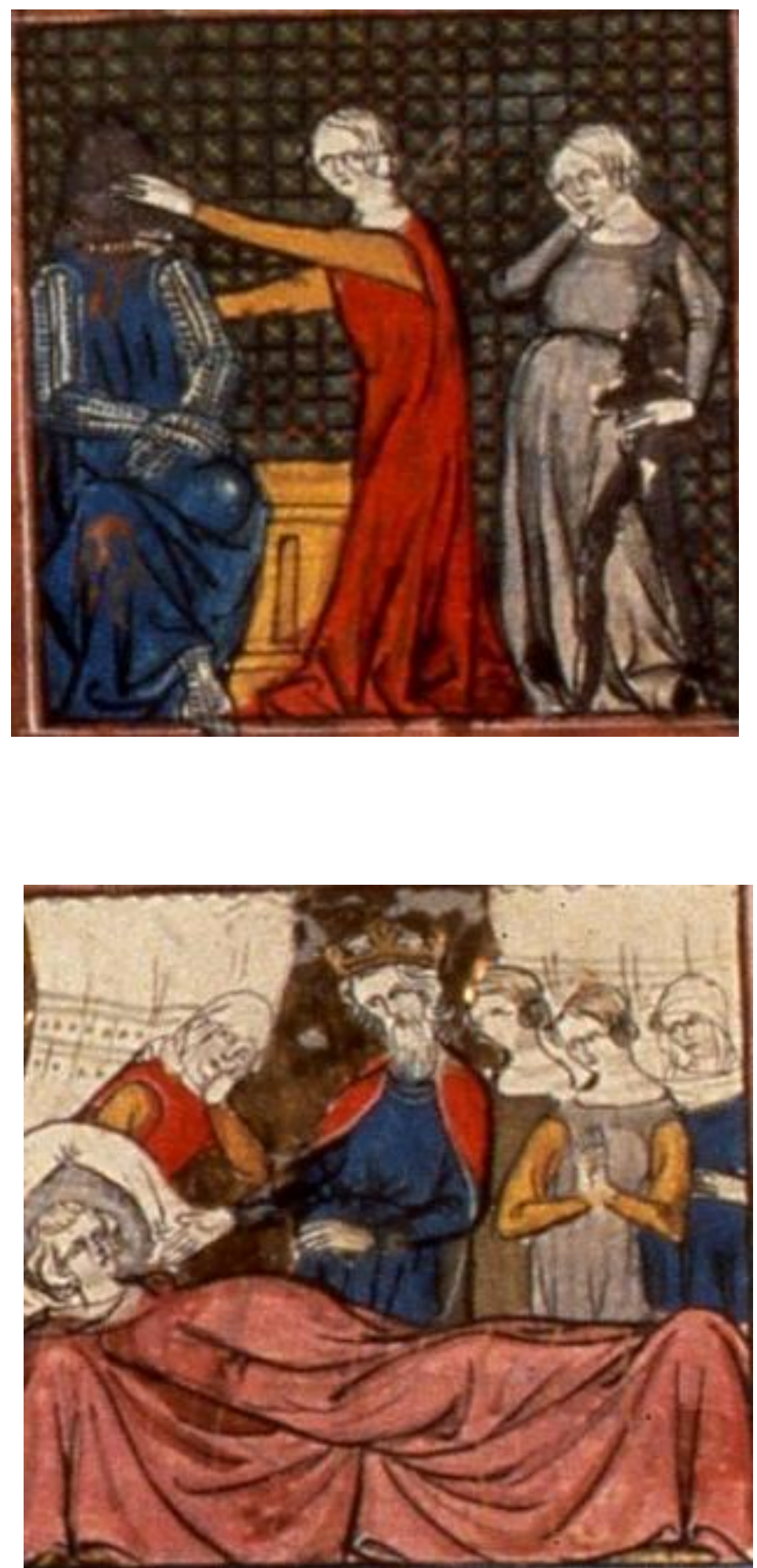
Este díptico que contiene las miniaturas 28 y 29 muestra la llegada de Héctor herido a Troya después de la batalla y la cura de sus heridas por sus hermanas y su madre, y la visita de Príamo a Héctor. Aparece Héctor sin armadura, tumbado, rodeado por sus hermanas y por su madre y, enfrente de él, el rey Príamo con la corona. La miniatura refleja las lamentaciones presentes en la obra escrita, reconstruyendo el escenario tradicional del planctus 150 cuyo patetismo queda traducido a la composición gestual:

Sa mere prist entre ses braz,

\section{E ses serors ostent les laz:}

Del chief li ont son heume osté,

Del sanc de lui ensanglanté.

L'auzberc li traitent de son dos

La nuit n'ot guaires de repos,

Ses genoillieres li osterent

Celes qui de bon cuer l'amerent.

(V.-1021910226)

\section{Dame Andromacha sa moillier,}

Cui el ot sor toz autres chier,

Plora des oilz mout tendrement,

E entor li puceles cent.

La n'ot eschar ne guab ne ris.

En un chier lit de cipraris

A entaille sarrazinor,

D'or e de pierres fait entor,

Covert d'un feutre chier e frois,

150. "planto del latín planctus. Composición elegíaca. Llanto con gemidos y sollozos", Real Academia Española, Diccionario de la lemgua española $22^{a}$, Madrid, 2001, consultado en http:// www.rae.es /rae html. 


\section{D'un drap plus blanc que niulle nois,}

\section{Estelé d'or menüement,}

\section{Le couchierent isnelement.}

$$
\text { (V. -10233-10244) }
$$

Ainz qu'il s'endormist, vint le rois,

Prianz li saives, li cortois.

$$
\text { (V. 10257-10258) }
$$

Miniatura 30, Folio 97: «Ci devise conment le roy Priant et Ecuba sa fame et Andromaca si font duel entour les cors de Hector qui est mort qu'Achillés occist».

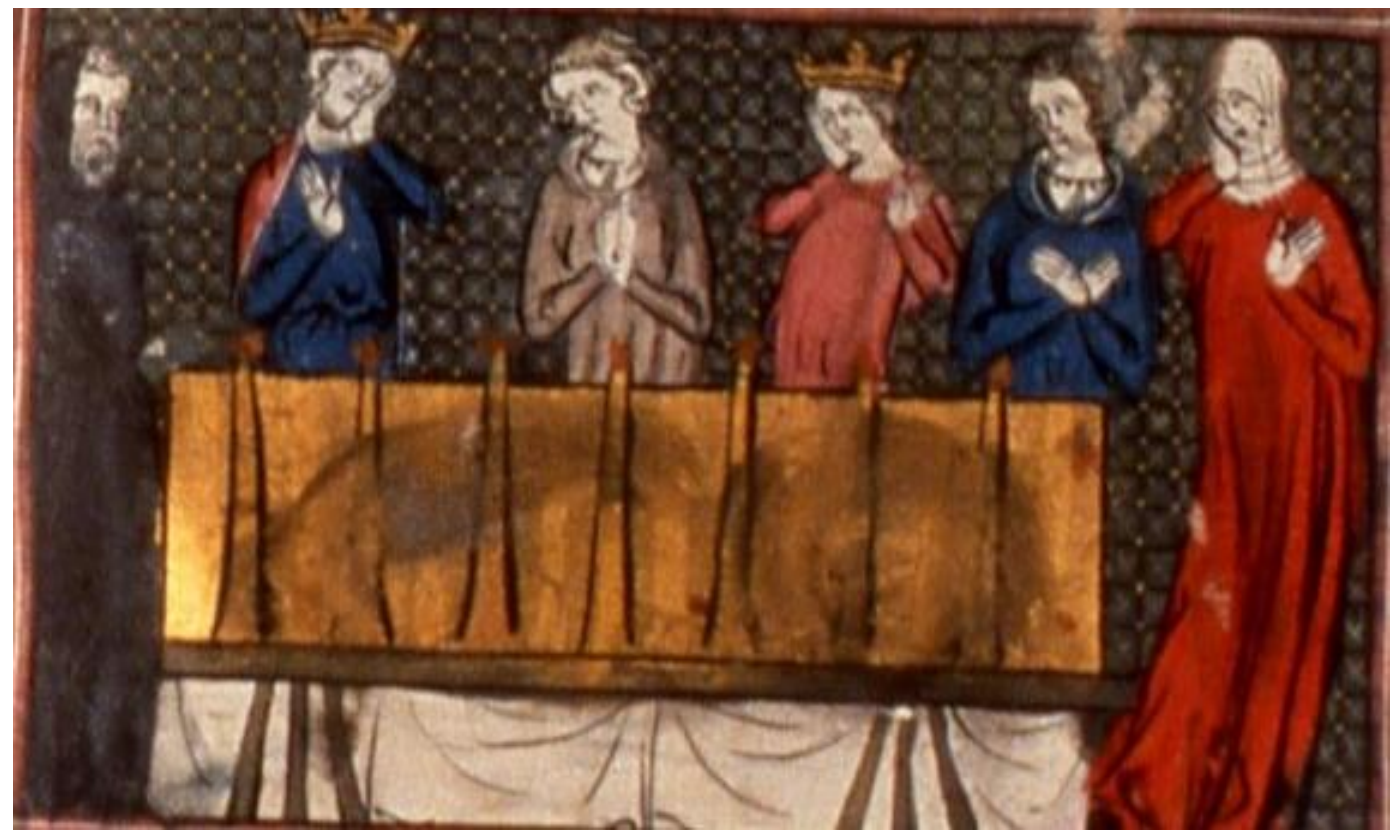

La miniatura 30 muestra el duelo, ante el cuerpo de Héctor muerto, de Príamo y Hécuba caracterizados con una corona y el mismo gesto de dolor por la simetría de la posición de sus manos y de su rostro. Podemos observar también la cristianización de la escena con la presencia de un monje en la parte izquierda de la escena que observa todo lo que sucede. Esta miniatura hace referencia al pasaje que nos muestra la reunión ante 
el cuerpo de Héctor muerto a manos de Aquiles. Al igual que la miniatura anterior, muy solemne, ésta tiende a fijar la superioridad guerrera de Héctor flanqueado por presencias femeninas que, a parte de Helena, tienen un papel destacado en la novela, como Hécuba y Andromaca que sufren por no haber logrado impedir la salida al combate de Héctor:

\section{$(\ldots)$}

Ont le cors Hector mis en biere.

Premierement l'ont desarmé

E de vin blanc set feiz lavé,

En chieres especes boiliz.

Avant qu'il fust enseveliz,

L'ont molt bien aromatizé,

E le ventre del cors saché.

$$
(\ldots)
$$

Dedenz ont lo cors enbasmé,

Sin i mistrentna grant planté,

E si refirent il de hors.

D'un drap qui iert en lor thesors,

Qui valeit plus de dous citez

D'or e de pierres estelez

Li plus riches qui ainc fust feiz

Ne qui ja mes nos seit retreiz,

De cel li firent vesteüre,

Bele e bien feite a sa mesure;

(V.16503-16524) 
Miniatura 31, Folio 73: «Ci devise comment les batailles des Griex et des Troiens s'entrasemblerent les uns contre les autres».

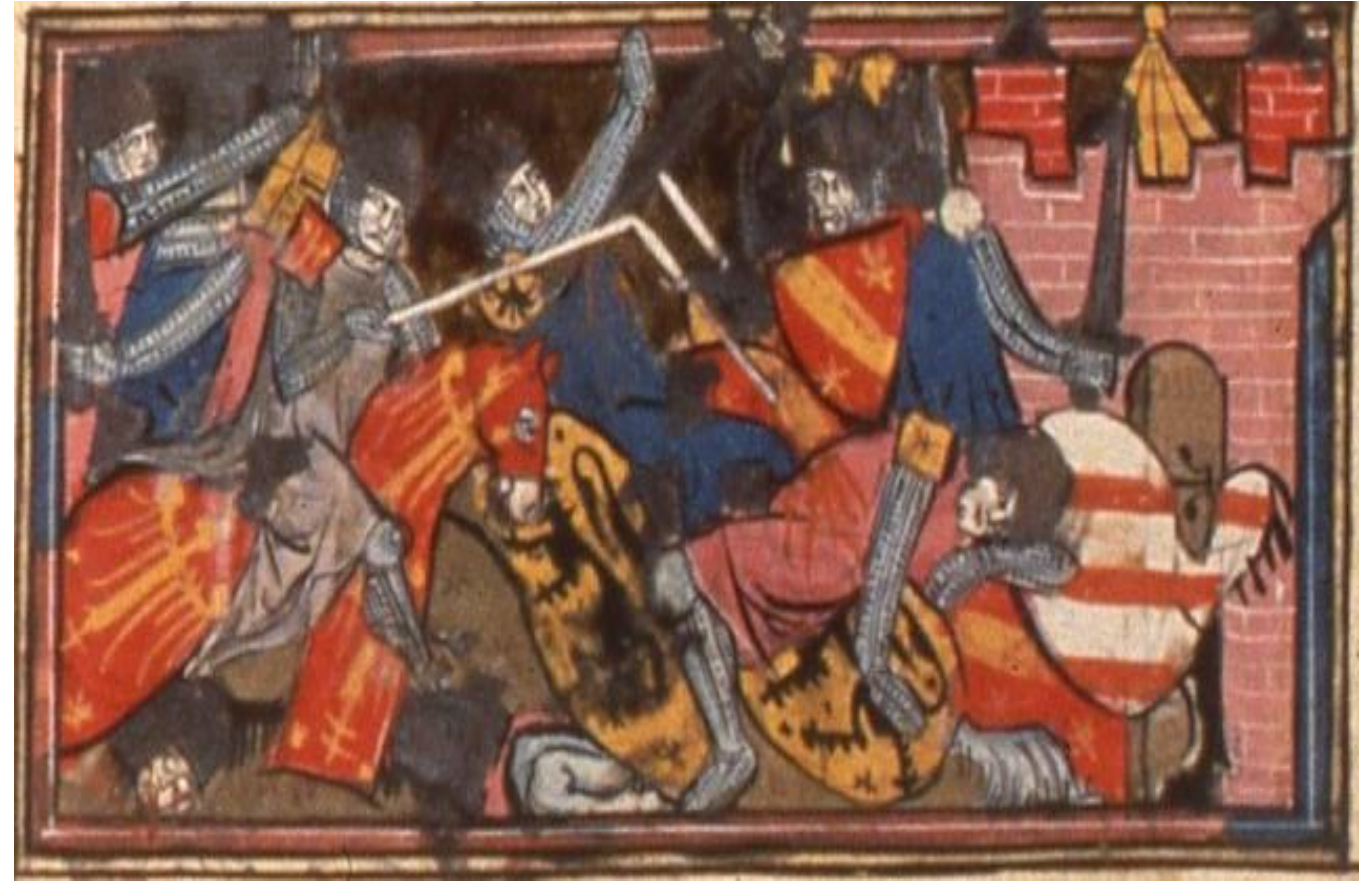

Miniatura 32, Folio 77: «Ci devise comme Hector est en la Bataille ou il fet grant decepline des Grijois, et comment Paris vint a l'estour ou il traiont aus Grieux».

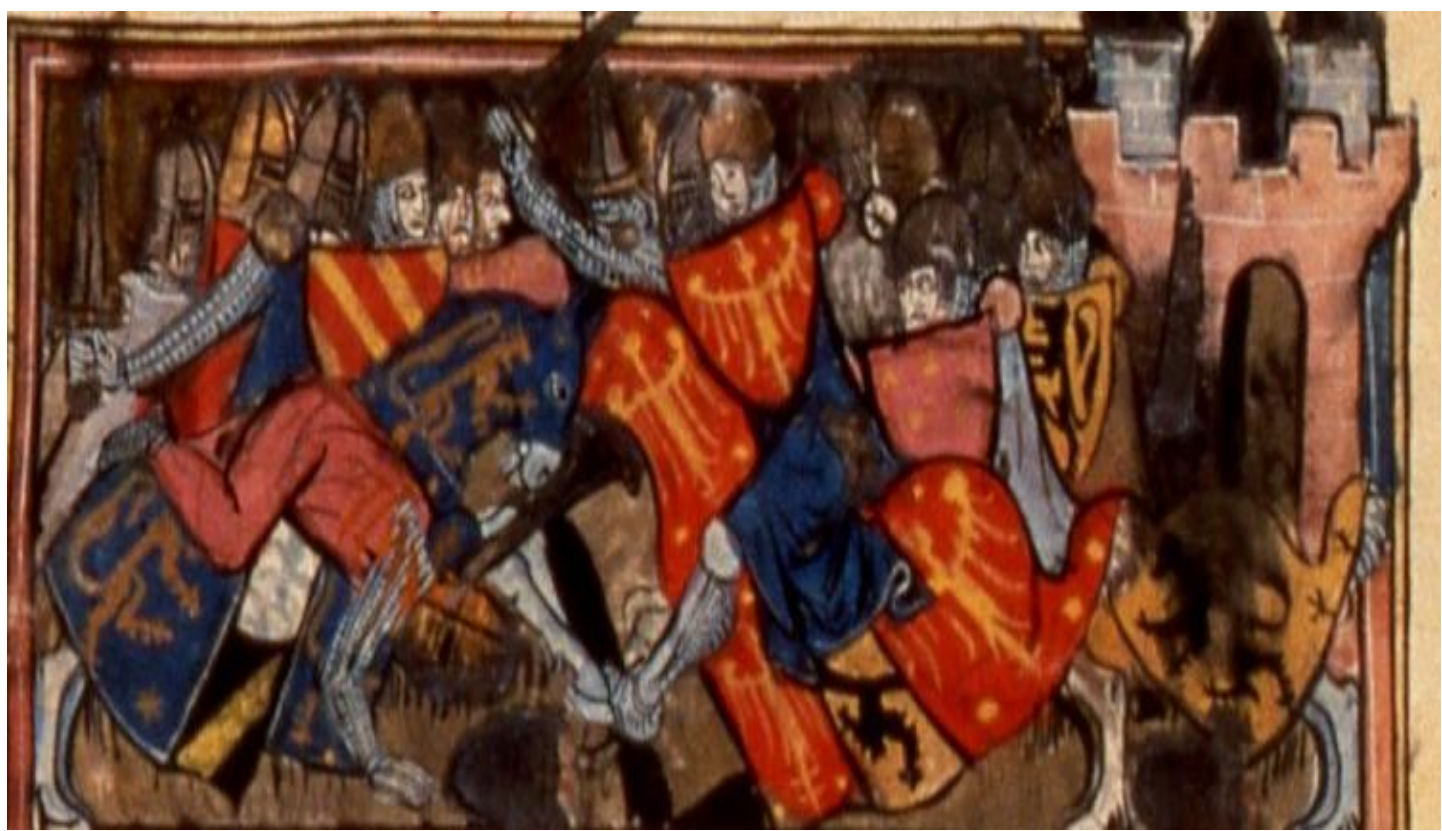


Las miniaturas 31 y 32 ilustran los numerosos combates relatados en la novela. Según Troie se realizan más de veinte batallas, de las cuales algunas están representadas en el manuscrito en forma de miniaturas, dejando demostrada la importancia del tema guerrero en esta novela. Todas las representaciones tienen en común la lucha armada de griegos y troyanos a imagen de una batalla medieval, sin detenimiento en los rasgos distintivos: todos los guerreros aparecen con los mismos gestos y las mismas actitudes sistematizadas en posición de ataque o defensa, reflejándose en esta vaguedad lo cruento de la batalla.

Miniatura 33, Folio 81: «Ci commence la tierce Bataille des Troïens et des Grijois, qui fu une des grans qui i fu, des toutes voies Grieux les confirent».

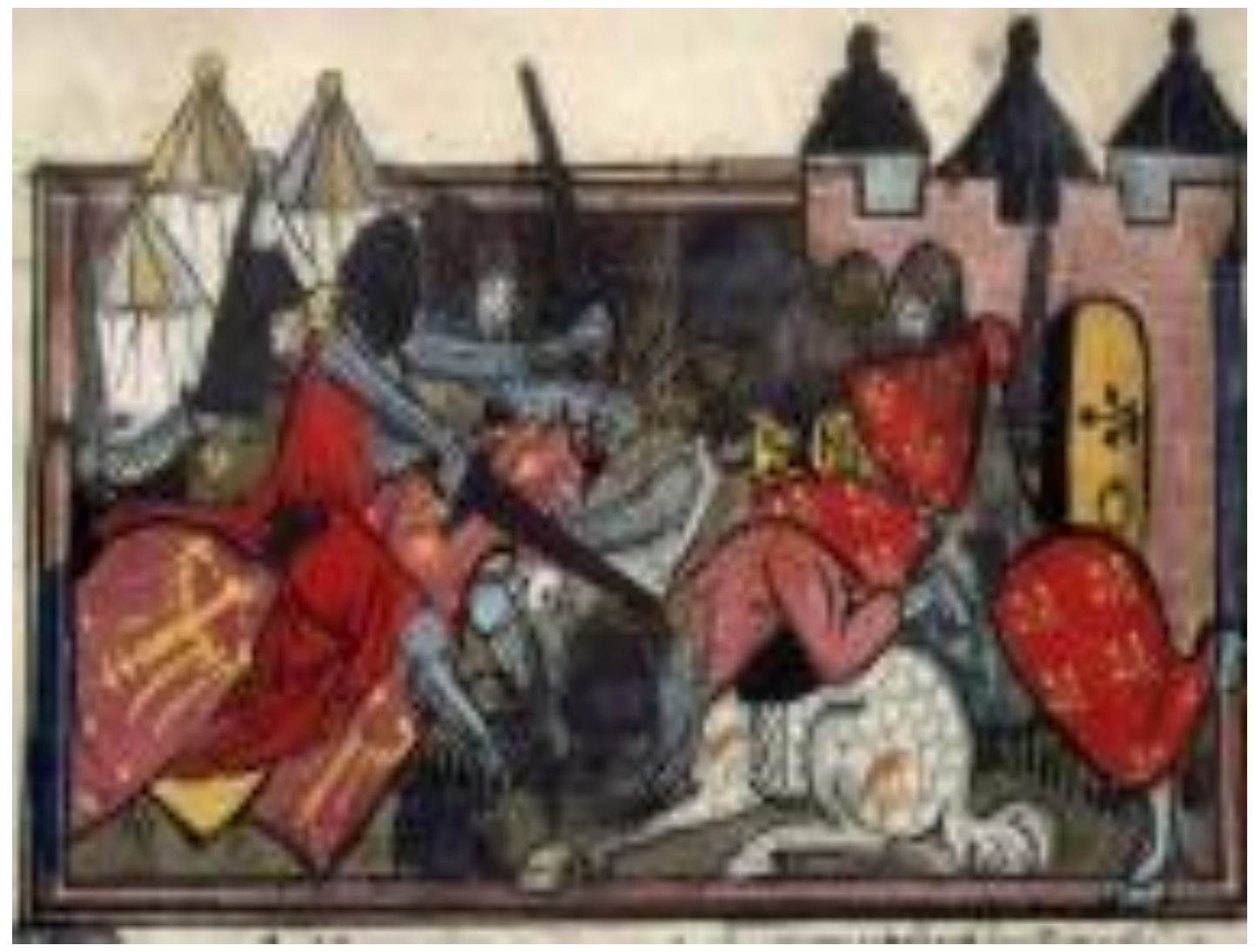


Otro ejemplo nos da la miniatura 33 que muestra un momento clave de la batalla, un tumulto en el que los personajes principales con las espadas en alto se disponen a golpear; como eco del siguiente fragmento:

Quant cil de Perse I sunt venu,

Qui aportent maint arc tendu.

Paris li biaus, li proz, les guie.

Ici ot riche cumpaignie:

Hauzbers orent e hauzbergeis,

De fer fu coverz chascuns d'els,

De dras de seie nués e freis.

(V. 9529-9537)

Miniatura 34, Folio 113: «Ci devise de la deseseptiesme Bataille des Grieux et des Troiens et devise comment li Troien vindrent sus Achillés tout a i. fes».

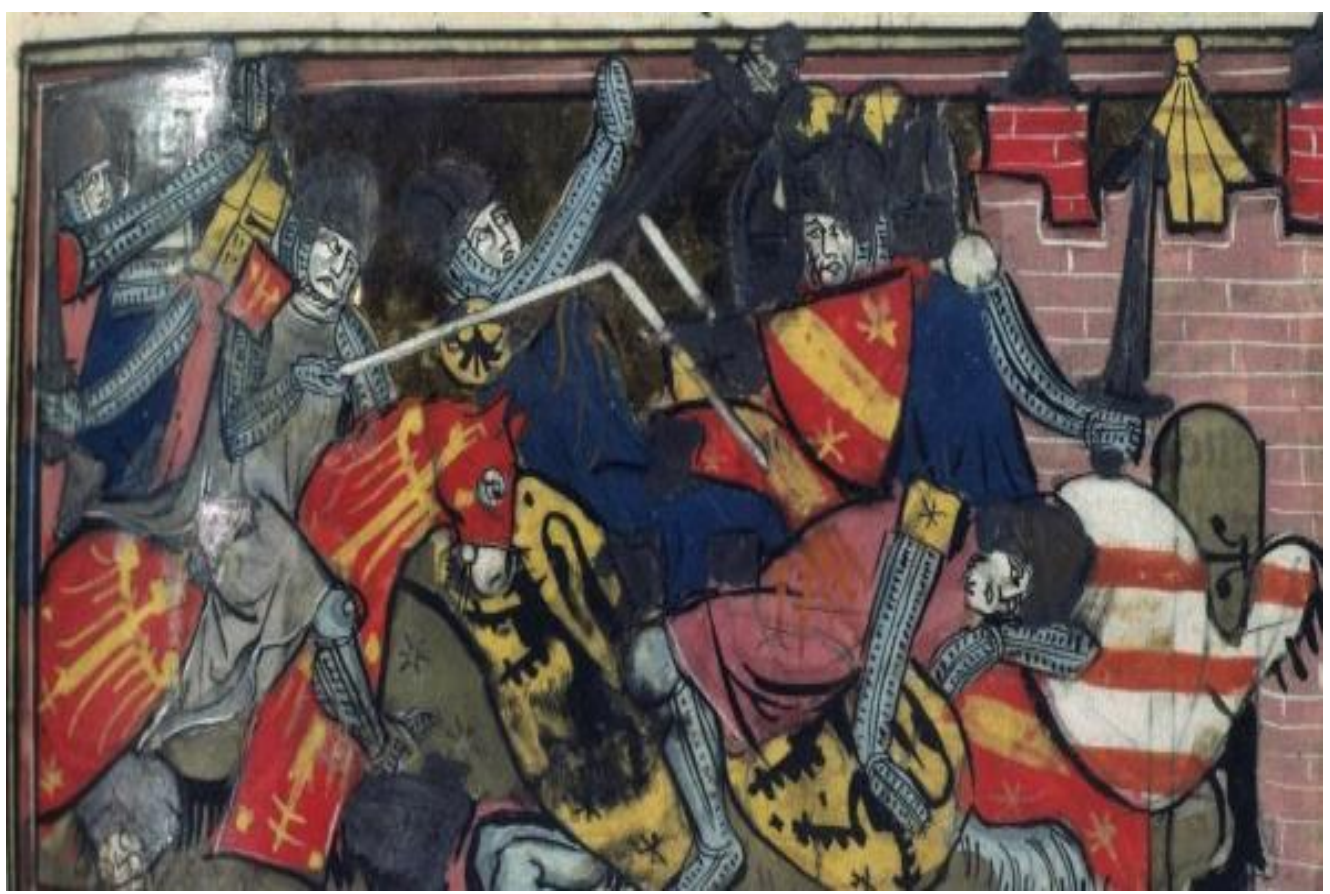


Aquiles es el protagonista de la miniatura 34, en la que se definen mucho mejor los contornos gestuales y la expresión de los rostros. Aparte de las numerosas batallas que aparecen en la novela, el miniaturista se dedica a fragmentos destacados como este que sirven para anticipar la negatividad de la batalla y el desenlace fatal de Héctor.

Miniatura 35, Folio 93: «Ci devise comment Andromaca tient le fiz Hector entre ses bras et li monstre, et conment sa mere et ses suers pleurent et font duel pour ce qu'il veult aler en l'ost. Et devise comment le roy Priant lo detint par le frain, si qu'il n'i ala mie a cele fois».

Esta miniatura es un ejemplo de representación sintética de la guerra, con una muestra de todos los elementos implicados: duelos a caballo, armaduras, escudos, lanzas con el decorado de un castillo medieval.

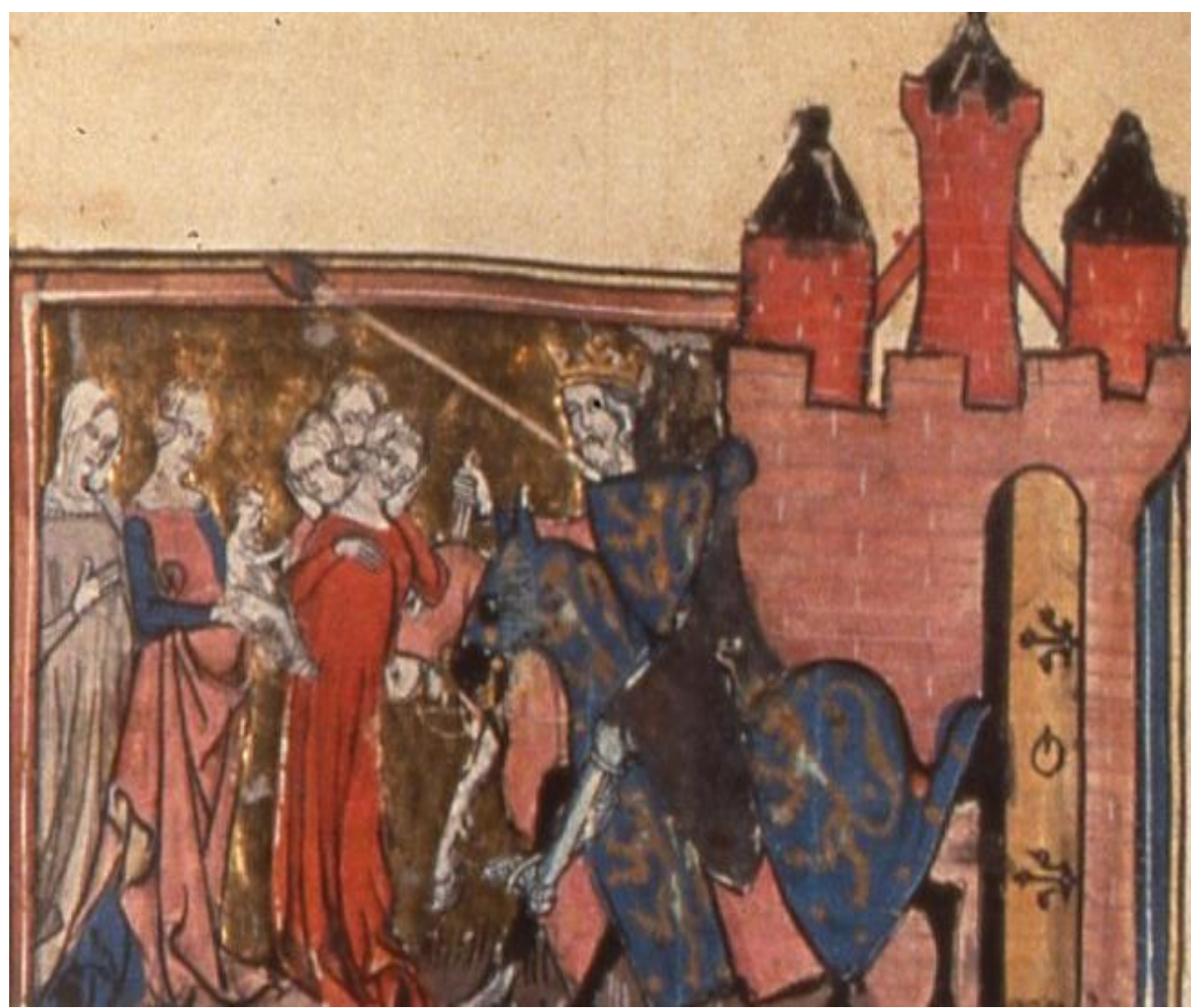


En el mismo sentido, la miniatura 35 se refiere al pasaje de la novela que hace hincapié en la negatividad de la batalla y la valentía de Héctor que, a pesar del peligro de la batalla, y de las súplicas de su madre y de su esposa, rechaza abandonar la batalla y sólo obedece a Príamo, su padre y rey, al que debe fidelidad:

Si grant duel a e si grant ire

Que par un poi le sens pert.

Au rei Priant mande en apert

Qu'il le li viet e le retienge,

Que leiz damages ne l'en vienge.

Sor tote rien gart n'i ait faille,

Qu'il n'aut le jor a la bataille.

Crient e dota li reis Prianz

Les perilz qui tant i sunt granz,

$$
\text { (...) }
$$

S'il sous n'i vait, la perte ert lor,

Sor elz revertira jor.

(V. 15356-15368)

Pero también, esta miniatura refleja explícitamente la tercera función desempeñada por mujer en la Edad Media, con la presencia de un niño en brazos, con un gesto protector, y en un segundo plano, representativo del que ocupan en la novela, cuya temática dominante es bélica. Son personajes secundarios en la lucha y en la toma de decisiones, teniendo únicamente un papel destacado dentro de la temática amorosa. 
Como hemos visto antes, uno de los protagonistas del bando griego, es Aquiles, al que se le dedican varias miniaturas. En el tratamiento de este personaje se asocian la figura del guerrero y la del hombre enamorado, por lo que todas sus representaciones, que confirman parte de su historia, comparten las dos temáticas, la de la guerra y la del amor.

Miniatura 36, Folio 101: «Ci devise comment cil de Troie alerent veoir l'aniversaire et la sepulture de Hector, et comment Achillés fi a meschiés par la grant biauté de Polizenam fille roy Priant, et en acoucha a malade en son paveillon»

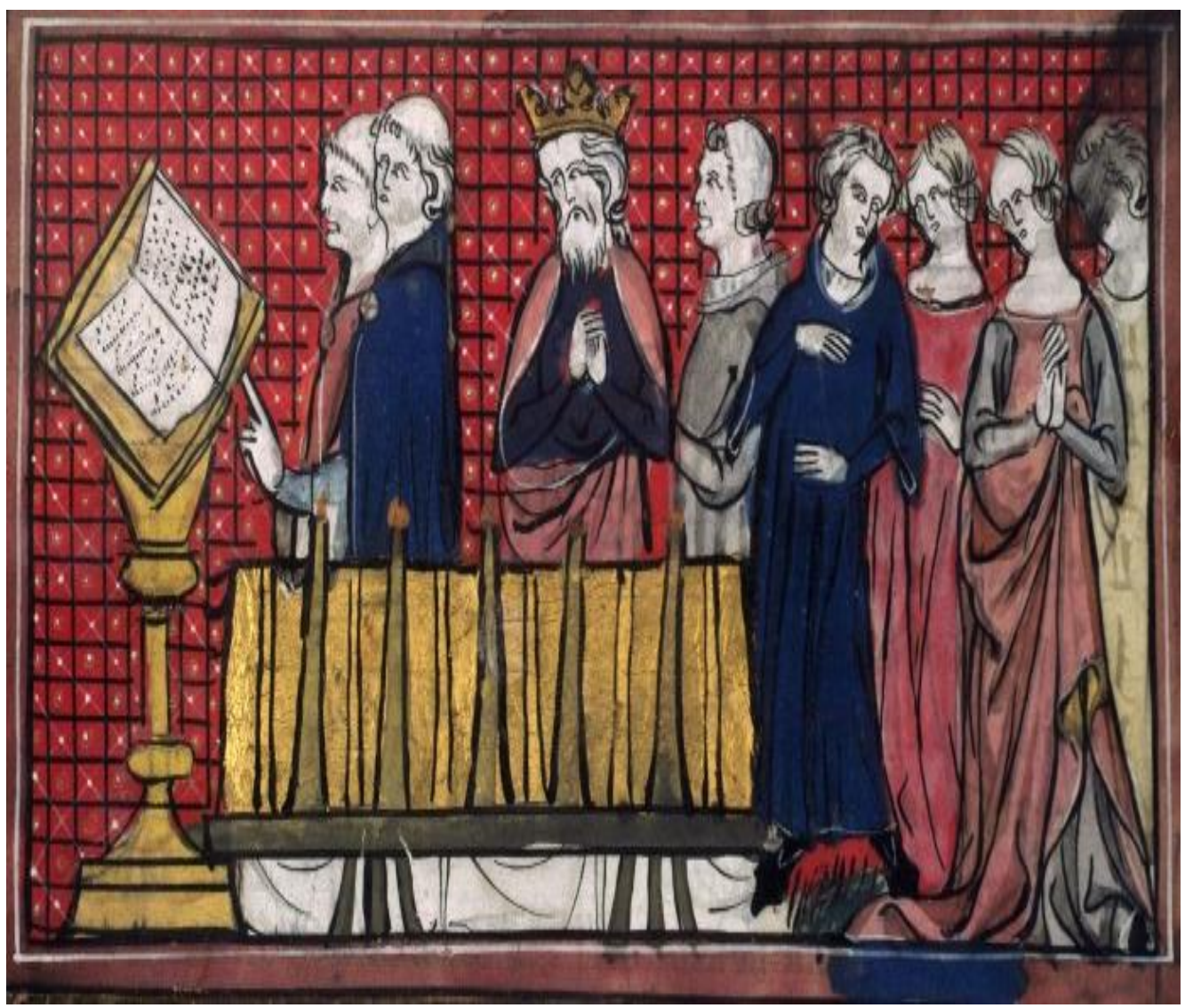


La primera miniatura cuyo protagonista es Aquiles es la número 36. En esta miniatura, tal y como lo expone la novela medieval, los griegos van a Troya para celebrar el aniversario de la muerte de Héctor. El recuerdo de Héctor se centra en la figura del caballero ideal, en su valor y su proeza. Héctor muere por defender su patria, y su figura de gran guerrero está ensalzada en numerosas miniaturas, como ya hemos visto. El episodio relacionado con la miniatura provocará el enamoramiento de Aquiles y Policena, hermana de Héctor. Aparecen pues dos tipos de caballeros: Héctor, que encarna al caballero ideal, y Aquiles, que se dejará llevar por sus pasiones de hombre, que lo conducirán a la muerte.

Des plus preiseiz de l'ost Grezeis,

Qui fussent, amirauz ne reis,

I veneient por esgarder

L'anniversaire celebrer.

Neis meïsmes danz Achillés

I vint toz desarmez si pres

Que bien poeit o elz parler,

Mes mielz l'en venist consirrer.

Mar i porta onques ses piez,

Car ainz que il fust reperez

$\mathrm{Ne}$ de la feste retornez,

S'est si il meïsmes atornez

Que sa mort a mise en son sein.

Veüe i a Polixenein

Apertement en mi la chiere:

C'est l'achaison e la maniere

Par qu'il sera gitez de vie

E l'ame de son cors partie

(V. 17527-17544) 
Al igual que en todas las miniaturas, se recrea la escena en un ambiente medieval, donde hay clara influencia de la mentalidad cristiana tanto en la representación de la ceremonia de aniversario de la muerte de Héctor como en las figuras que aparecen en la escena. No sólo por la figura de Príamo caracterizado por la corona y por la posición de sus manos en la actitud de orante, sino también por las dos figuras que aparecen en primer plano, que se asimilan a figuras religiosas típicas medievales. Además podemos destacar la presencia de un objeto emblemático de la mentalidad cristiana como es el misal colocado en un atril y que parece atraer la atención del rey Príamo y justificar su actitud orante.

Miniatura 37, Folio 107: «Ci devise la saizieme Bataille de Troiens contre Grijois, en la quele Achillés ne volt aler pour l'amour de Polizena s'amie».

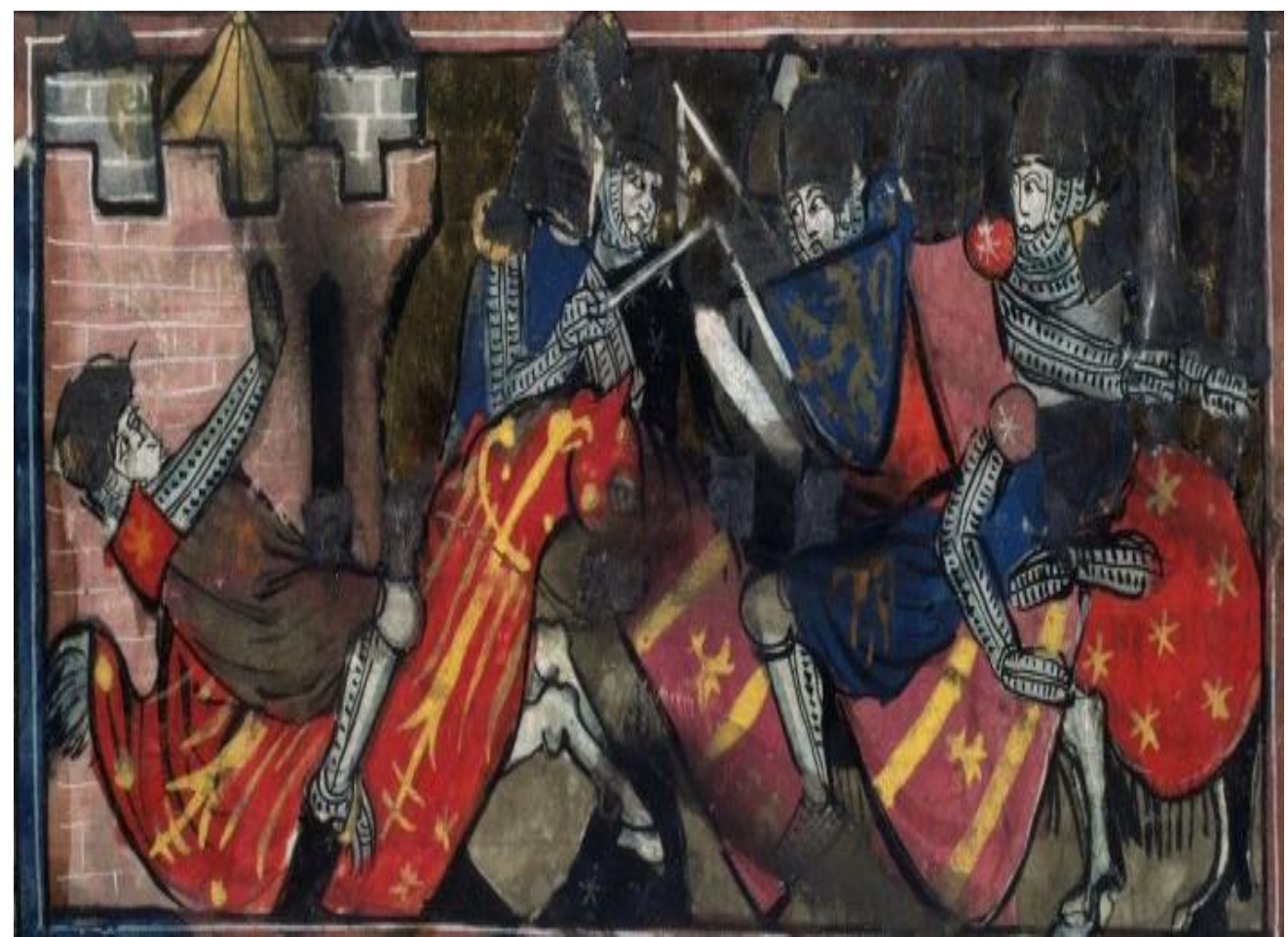


Dentro del análisis de las miniaturas cuyo personaje principal es Aquiles, la miniatura 37, como contrapartida, nos muestra la negativa de éste a formar parte de la batalla contra los troyanos. Esta miniatura refleja otra faceta de la batalla entre troyanos y griegos a través de la dualidad de Aquiles que deja de lado sus ideales de caballero para adoptar los ideales de hombre enamorado. Esta dialéctica entre guerra y amor, muy sensible en la novela se explicita gestualmente en la miniatura de la batalla número 16 en la que se escenifica la negativa de Aquiles en el personaje de la izquierda con la mano levantada, signo de rechazo o impotencia. El correspondiente fragmento muestra los reproches que, al respecto, le hacen los guerreros:

Qui tres bien est d'amour espris,

Pou a en soi sens ne raison.

Ainsi par iceste achoison

Guerpi armes dans Achillés.

Blasmez en fu lonc temps aprés.

La seue gent e sa mesniee

En iert doulereuse e iriee:

De duel les veïst on plorer,

Qu'il n'osoient armes porter.

(V. 18458-18466)

Señalamos de paso que, en el manuscrito, la batalla representada es la 16 , sin embargo la novela nos dice que es la 12 en la que Aquiles no participa: aparece aquí otro cambio de enfoque con respecto a la novela de Benoît de Sainte-Maure. 
Miniatura 38, Folio 117: «Ci devisent comment Achillés fu ocis ou temple de Minerve por l'enortement de Paris et de sa mere qui le mandarent dont il le traïrent».

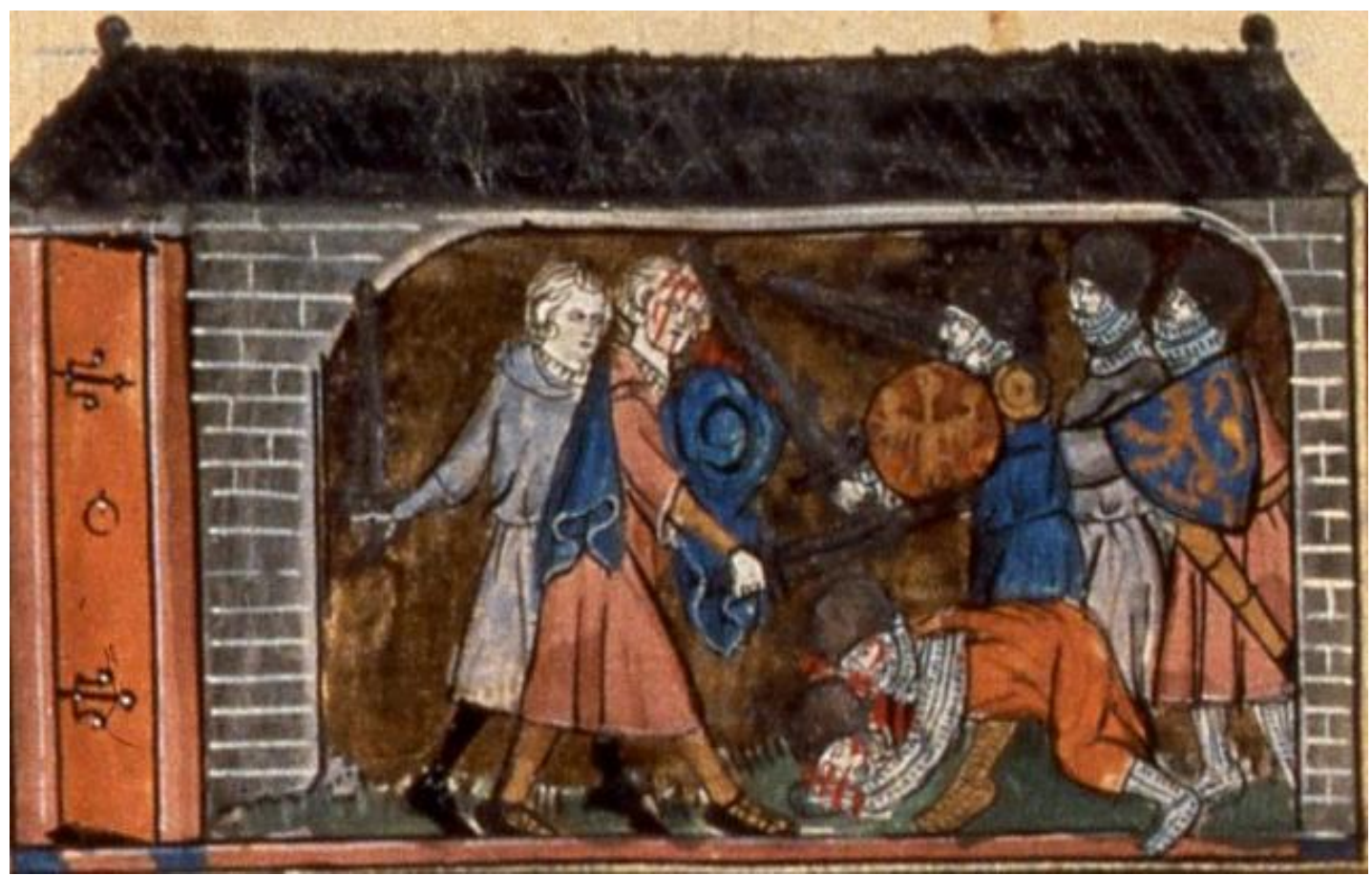

La miniatura número 38, cuyo personaje principal sigue siendo Aquiles, presenta un cambio respecto a la novela escrita: esta miniatura nos reproduce la emboscada que sufre éste. En este caso, el miniaturista modifica el escenario: sustituye el templo de Apolo, como refleja la novela, por el templo de Minerva ${ }_{151}$, menos acorde con Aquiles que no muere en la batalla sino por amor, descuidando su función guerrera, pero que realza quizá el mérito del guerrero griego frente al "enortement" de Paris, así como la implicación de una diosa belicosa en un combate de "uno solo contra dos":

151. "Minerva también llamada Atenea. Las características esenciales de Atenea, admirablemente sintetizadas en el himno 7 de Proclo, son las de diosa auguata, diosa virginal, belicosa, protectora de guerreros esclarecidos, y a la vez patrocinadora de la inteligencia y de las artes manuales, defensora de ciudades, y, muy especialmente, defensora y epónima de la ciudad de Atenas". Ruiz de Elvira, A., Mitología clásica, Editorial Gredos, Madrid, 2011, p.93. 
Le lué troverent molt segrei:

Hidor lur en prist e esfrei.

Descendu sunt li bon vassal;

Chescuns aresna son cheval.

Li sans lur est montez es vis.

\section{Dedenz lo tenple Apollinis}

\section{S'en entrerent merveille ont grant \\ Qu'il n'i troverent rien vivant.}

Enhardi sunt en lor corage:

Ja paristra cum il sunt sage!

De Quatre parz lur sunt ailli,

A une voiz a a un cri,

\section{Li vint qui erent enbusché.}

$$
\text { (V. 22169-22181) }
$$

Así, el espacio consagrado a Minerva, sin que aparezca la figura de la divinidad, es el de la última lucha de Aquiles, atacado por varios en el suelo, intentando librarse de los troyanos. Al mismo tiempo, la imagen de Paris queda plasmada como la de un traidor, tal y como lo expone el texto:

Cum de lui se puisse vengier,

Nus hom ne s'en deit merveillier

N'a mal n'a blasmë atorner.

Paris a fet a sei mander.

Il iert de ce toz coneüz

Qu'il iert de convenenz menuz.

(V. 2185-21856) 
Miniatura 39, Folio 119: «Ci devise comment Paris fu tué et comment il fu mis en sepulture et ploré».

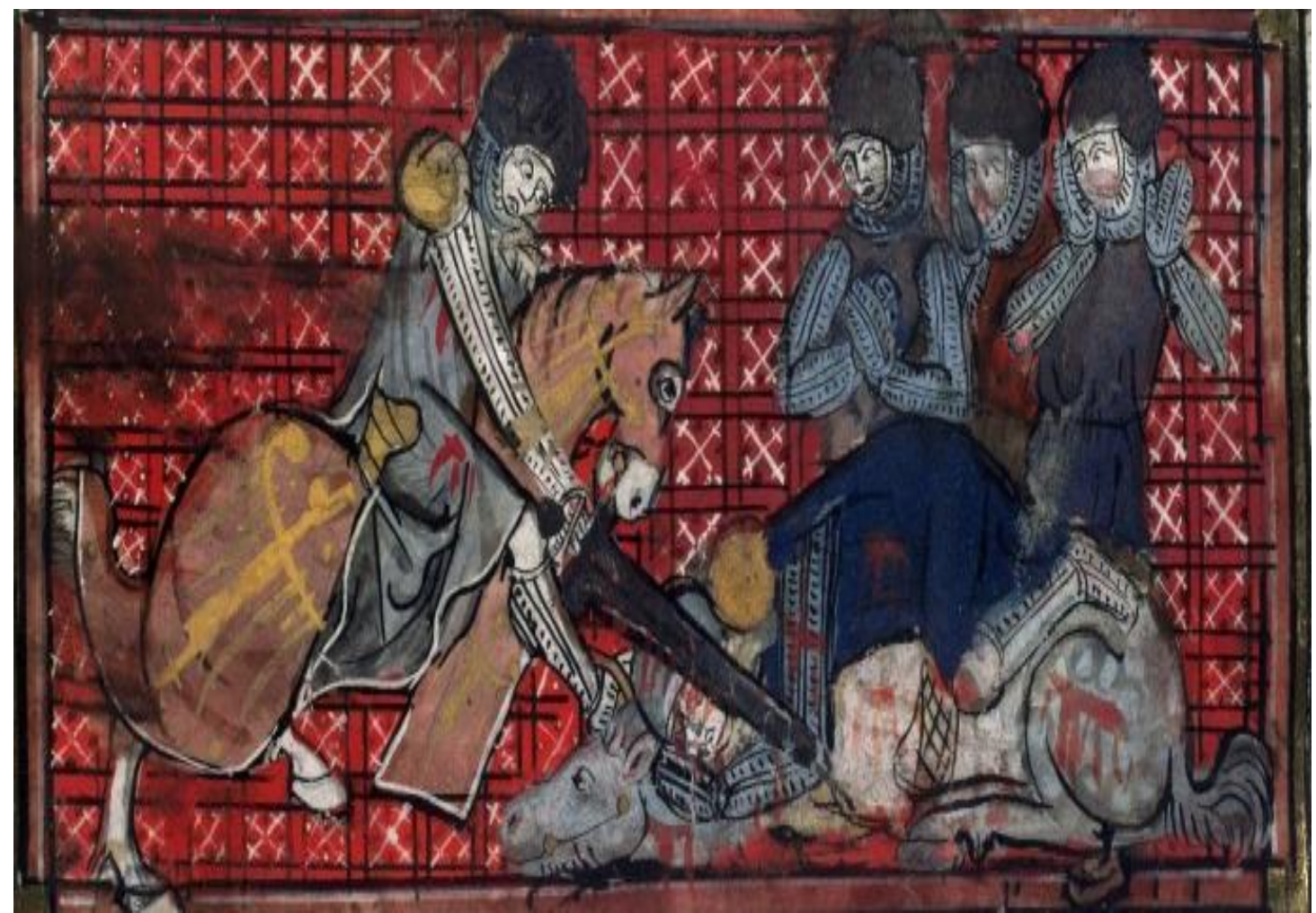

La miniatura número 39 nos muestra la muerte de Paris. De hecho, las miniaturas sólo hacen referencia a las muertes de los jefes troyanos, la miniatura anterior hace referencia a la muerte de Aquiles, conforme a la importancia que les otorga Benoît de Sainte-Maure. La muerte de Paris concluye la representación de las grandes batallas entre griegos y troyanos y decreta el final de la guerra.

Fait Aïaux: "Sire Paris,

Je cuit qu'or estes entrepris:

Se avez tret a mei de loingz,

Vers vos me sui serrez e joingz.

Ocis m'avez, jel sai e sent, 
Por quant s'ert ja premierement

Vostre ame en enfer de la meie:

Je voill que se mete a la veie.

Ja n'en trairez mes d'arc d'aubor.

Ici deseivre vostr' amor

D’Eleine, qui mar fust ainc nee,

Que tante gent ont cumparee.

Por li morreiz, e je si faz."

(V. 22801-22814)

Miniatura 40, Folio 126: «Ci devise conment Pantyselee la royne de Femenie fu tuee et comment ele fu jetee en une yane dont elle fu puis hors traite».

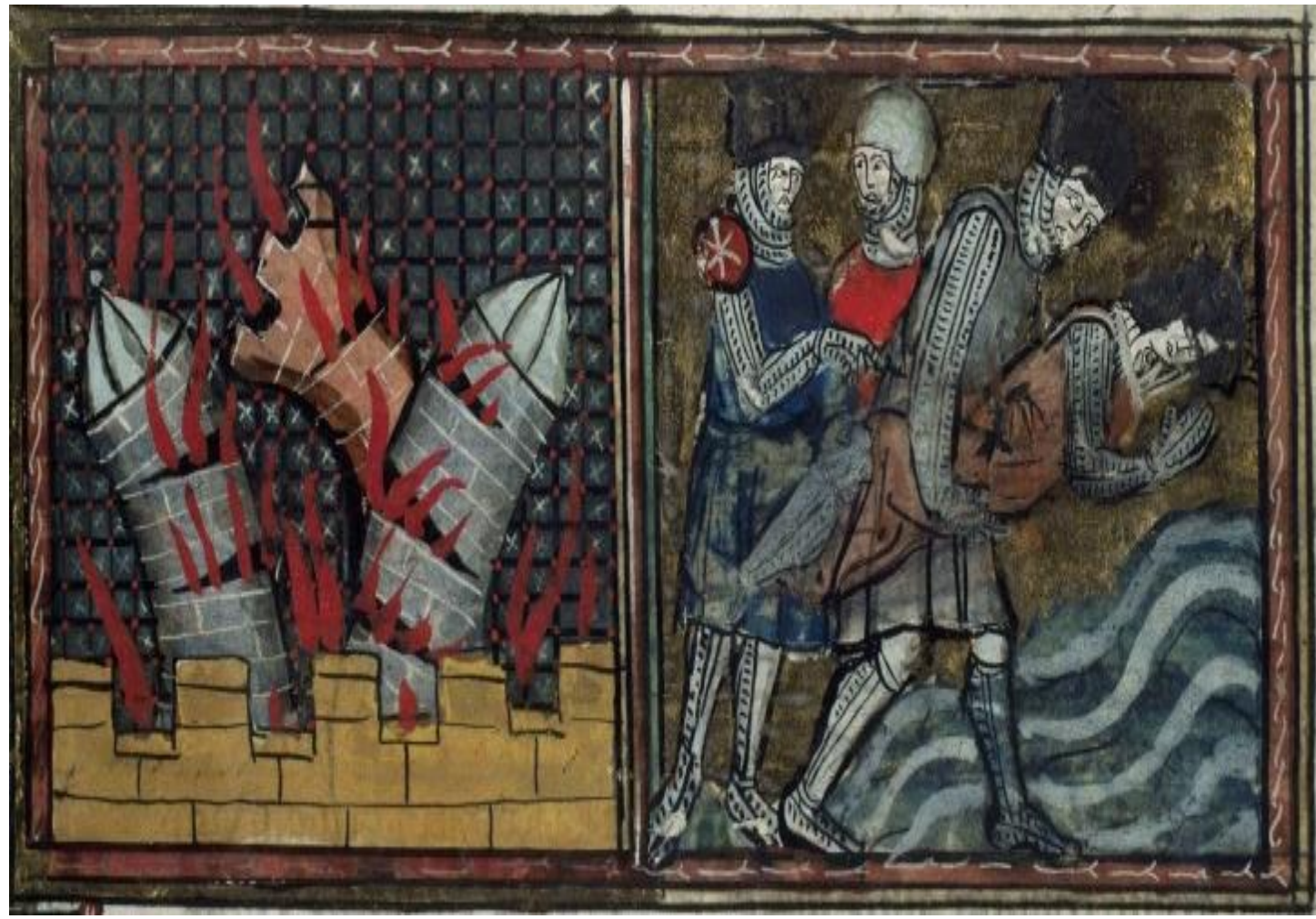


La miniatura 40 se compone de dos miniaturas que reflejan dos escenas diferentes. La primera representa a Troya devastada por las llamas después de la batalla que dará la victoria a los griegos, poniendo fin a la guerra, y la segunda nos muestra algo hasta ahora inédito: una mujer guerrera. En efecto, la novela omite cualquier descripción de la mujer en la lucha, y esta miniatura constituye la única representación de la mujer guerrera en Troie. Refleja el castigo cruel de Pentesilea, reina femenina, ataviada como un caballero:

Neptolomus n'agree mie,

Ainceis vout qu'el ait sepolture

E son mestier e sa dreiture;

"Dolor sereit e retraçon

Se s'ame aveit dampnatïon."

Tot ce desvout Dïomedés;

Sor toz en est fels e engrés.

A toz vout fere otreier

Qu'a chiens la dongent a mangier

$O$ en un des flueves gitee.

La savons bien qu'il la giterent:

C'est une eve granz e parfunde.

(V. 24446-24458) 
Miniatura 41, Folio 129: «Ci devise conment li baron de Gresce, vindrent a Troie pour parler au roy Priant, et jurerent ensemble la pais et l'acordance de tout en tout».

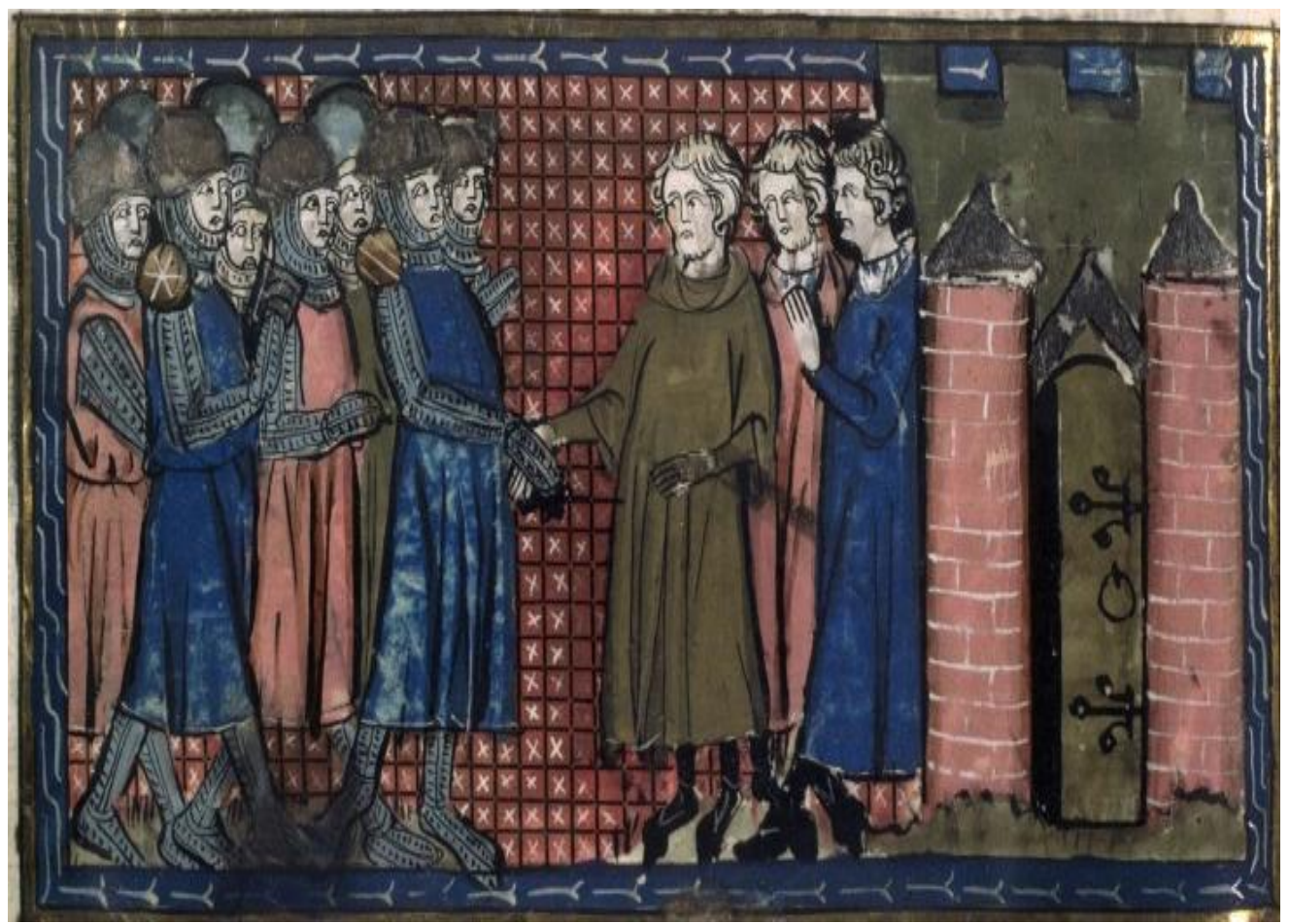

Esta última miniatura corresponde a la etapa final de Troya, donde el rey Príamo se rinde ante los griegos. La guerra tan sangrienta que ha provocado tantas muertes termina con la firma de la paz entre troyanos y griegos. En esta miniatura, podemos ver a varios guerreros griegos y al rey Príamo que sigue representando los valores de la monarquía. La posición de los troyanos a la derecha, como en todas las miniaturas analizadas, destaca el valor positivo que contrasta con la negatividad representada por los griegos. A modo de resumen, esta miniatura reflejan dos de las clases sociales dominantes en la Edad Media: la caballería y la monarquía, ambas representadas con sus símbolos característicos, sellando la paz con un apretón de manos. Cabe destacar la indumentaria de los vencedores que llevan la armadura de caballeros frente a los troyanos vestidos con simples túnicas.

La novela de Benoît de Sainte-Maure termina con la muerte de Policena y las numerosas disputas entre los griegos por la posesión del Palladion. La venganza contra las mujeres troyanas no aparece representada en las miniaturas, pero sí la firma de la paz 
entre los troyanos y los griegos, en esta última miniatura, la número 41, que es la que cierra la novela, anunciando la paz y la concordia.

Al analizar las miniaturas nos hemos dado cuenta que el miniaturista sólo reproduce los hechos más relevantes para la comprensión de la novela y destaca los elementos que se adaptan a la mentalidad medieval. También hemos podido constatar que, las miniaturas por sí solas pueden ofrecer al espectador una visión general y coherente del argumento de la novela, sin haberla leído.

Por otra parte, el estudio de este manuscrito demuestra el valor del apoyo gráfico de las miniaturas, desde su función ornamental hasta su papel de significación con relación al propio texto. También son reveladoras de los diversos cambios introducidos con respecto a su modelo del siglo XII y al clásico entre la máxima fidelidad y el margen de libertad creativa que se otorgaba al autor de las miniaturas. Desde un punto de vista histórico, ya no meramente literario, son igualmente aclaratorias, ya que ofrecen un muestrario riquísimo en cuanto a la indumentaria, la arquitectura, los cánones de belleza, y los espacios de la época. Por eso tanto para el lector de aquella época como para el lector actual, constituyen un soporte documental y una ilustración artística que no es sólo motivo de adornamiento sino que pretende aportar conocimiento sobre la obra y sus fuentes, dejando a la vez una ideología la de un pensamiento subjetivo sobre la recepción de dicha obra y sus fuentes.

La observación de estas últimas miniaturas del manuscrito $\mathrm{BN}$ fr 60 , contribuye a evidenciar la importancia y la difusión de Enéas y Troie a lo largo de los años posteriores. Elaboradas durante el siglo XII, su trasmisión se ha realizado a través de su reproducción en numerosos manuscritos, prueba de que su lectura despertaba un gran interés en la sociedad de la época.

A lo largo de este estudio se ha ido reforzando la idea del valioso apoyo gráfico de la miniatura tanto para el adornamiento como para la comprensión de las adaptaciones medievales de novelas clásicas. En este sentido, las miniaturas reproducen 
igualmente el anacronismo, tan característico en esta literatura del siglo XII; los héroes clásicos pasan a ser verdaderos caballeros en un ambiente claramente medieval, en el que se pone de relieve la ausencia de la mitología clásica todavía muy presente en las obras clásicas adaptadas. Las reinterpretaciones que realiza el escritor con respecto a su modelo clásico también aparecen en este manuscrito: el miniaturista crea una nueva perspectiva en ciertos episodios con respecto a las novelas medievales, renovando así su interpretación.

A través de las miniaturas este manuscrito representa lo destacado y novedoso de aquella literatura que no se limitaba a una mera adaptación de obras clásicas sino que llegó a ser el germen que dará lugar al desarrollo del género novelesco dentro de la literatura francesa, proporcionando los primeros esbozos de creatividad y técnicas literarias. Por ello, el conocimiento de estas obras es de gran importancia, no sólo por su amplia difusión sino porque "le roman français qui, sous ses nombreux avatars, a connu une si longue et triomphale existence, a reçu du génie latin la première étincelle de $\operatorname{vie}_{152} "$

Pues este genio antiguo, el de los gigantes clásicos, está en el origen del género novelesco, en el que la mitología encontró un lugar propicio, donde ficción y "autenticidad" se unieron, moduladas por el imaginario medieval, tal y como se plasman en la miniatura. La translatio y las miniaturas, atestiguan la atracción por la Antigüedad, atracción que no se ha debilitado hasta nuestros días, habiendo llegado a estos escenarios a lo largo de la historia: «à l'inverse de ce que l'on pourrait croire, le XIXe siècle n'a pas renoncé à cette fascination pour un temps antique, épique, révolu ou fictivement réinventé. Depuis l'évocation plus intime à la réminiscence ou l'héritage de mythes et des chefs d'œuvre,-entre la justification, la rupture ou la synthèse, l'Antiquité reste référence obligée quelquefois scientifiquement imprécise- par l'essor du roman historique où, de nos jours, cloîtrée à l'intérieur des scénarios consommés globalement: Troie et Alexandre (Oliver Stone), Gladiator, The Kingdom of Heaven, (Ridley Scott)... parmi bien d'autres $153 »$.

152. Faral, E., Recherches sur les sources latines des contes et romans courtois du Moyen âge, Genève-Paris, Slatkine Reprints, 1983 , p.419.

153. Ancinas, B., «Art et Antiquité, l’influence de la littérature», in Percepción y Realidad, Estudios francófonos, Madrid, 2007, p.1120 ss. 
A modo de colofón, cerraremos este capítulo con la ilustración complementaria: de dos miniaturas contiguas al texto de otros dos manuscritos del siglo XIII, emblemáticas también de la temática guerrera en las novelas objeto de nuestro trabajo. 


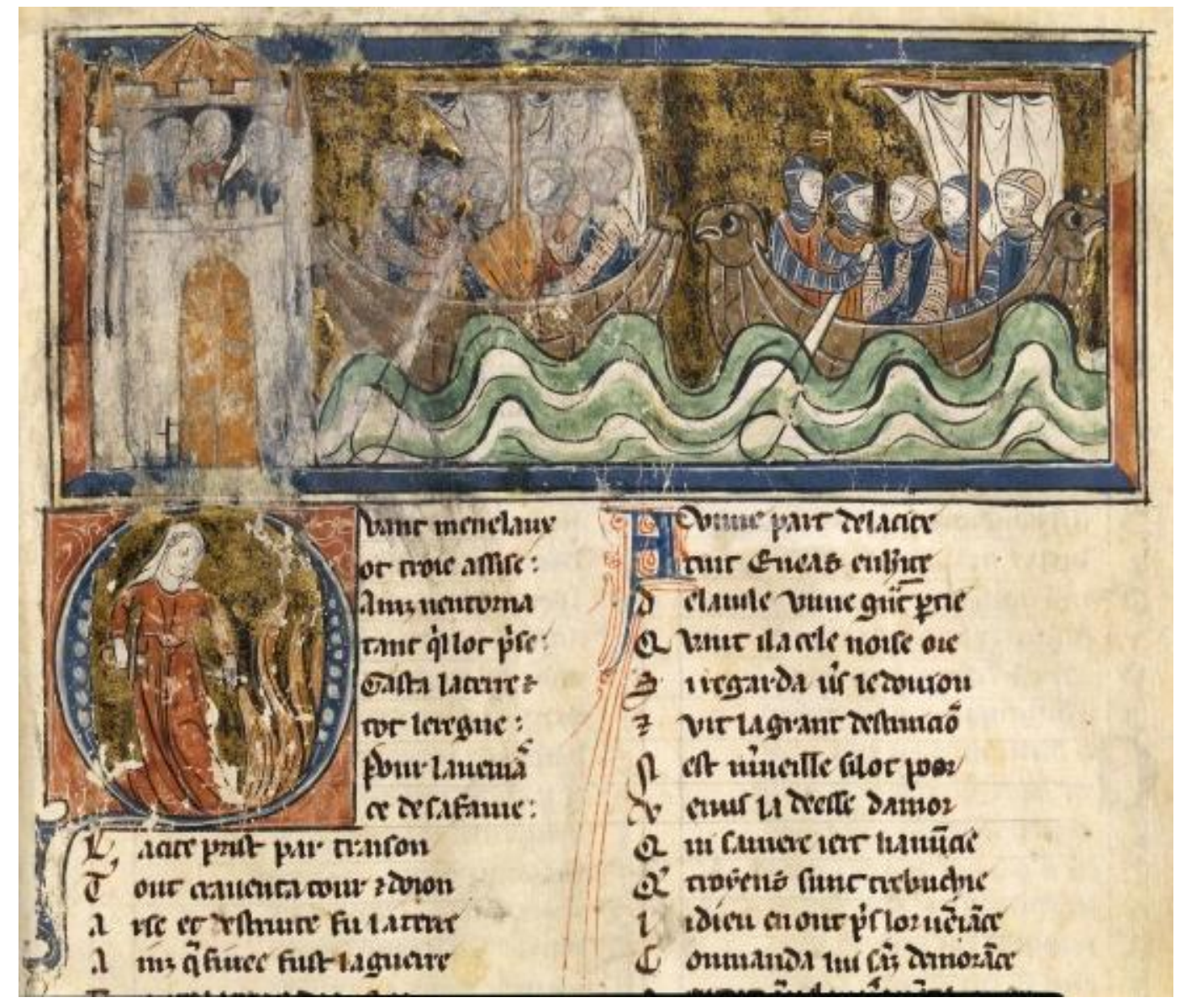

\section{Manuscrit BN Fr 784 fol 70 Enéas, XIII siècle}

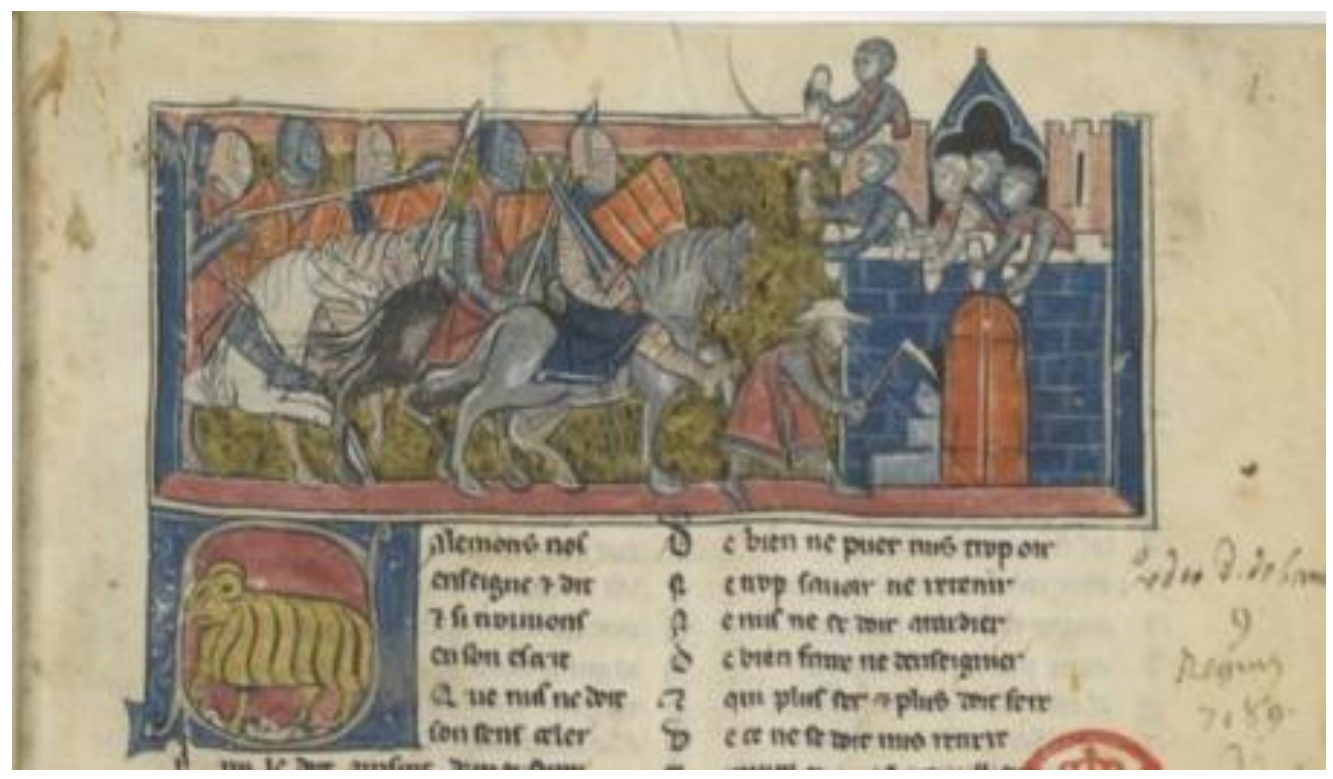

Manuscrit BN fr783 Troie XIII siècle 


\subsection{LA REPRESENTACIÓN DE LO MARAVILLOSO EN LAS MINIATURAS DE RICHARD DE MONTBASTON:}

Este último apartado del análisis del manuscrito BN fr 60 está especial e exclusivamente dedicado a un elemento literario destacado en estas dos novelas y al que, de forma directa o indirecta, se ha referido a lo largo de este trabajo: lo maravilloso. Para delimitar y centrar este estudio específico he seleccionado dos miniaturas muy singulares de la novela de Troya del manuscrito $\mathrm{BN}$ fr 60 , que reflejan de una manera muy clara la presencia de lo maravilloso, pertenecientes al iluminador y copista Richard de Montbaston. Los dos episodios reflejados por las miniaturas constituyen una muestra pictórica muy representativa de la presencia de lo maravilloso en la literatura medieval, de su interpretación y adaptación a la época en la que se realizan. Es en estas dos miniaturas consideradas por separado, donde se canaliza el tratamiento de lo maravilloso y donde podemos constatar su pervivencia.

Observando las miniaturas seleccionadas para este apartado nos damos cuentam que efectivamente, la imaginación y la interpretación son dos vectores que, en la translatio, condicionan la escritura, impregnada de significados y sobresentidos ligados a la presencia de lo maravilloso: "L'étymologie du mot merveille (mirabilia) implique d'abord un étonnement, qui se nuance de crainte, d'admiration ou de fascination. Le merveilleux s'explique alors comme la "réception" de cette autre culture par la culture commune devant les manifestations d'autres croyances. Car le merveilleux ne se donne pas tout à fait comme credible, mais nous renvoie à un passé ou un ailleurs, où ce qui se donne à voir aurait été $\mathrm{cru}_{154}$. 
Folio 141: "Ci devise comment II demoiselles et II damoiseau sont assis sur IIII piliers les buns contre les autres. Et tiennent l'une des damoiselles I mirer et l'autre joue de plusieurs jeux. Et l'un des danziaus ot en son chief couronne et tient plusieurs instruments. Et l'autre danziel tient I encenssier d'argent et les encensse".

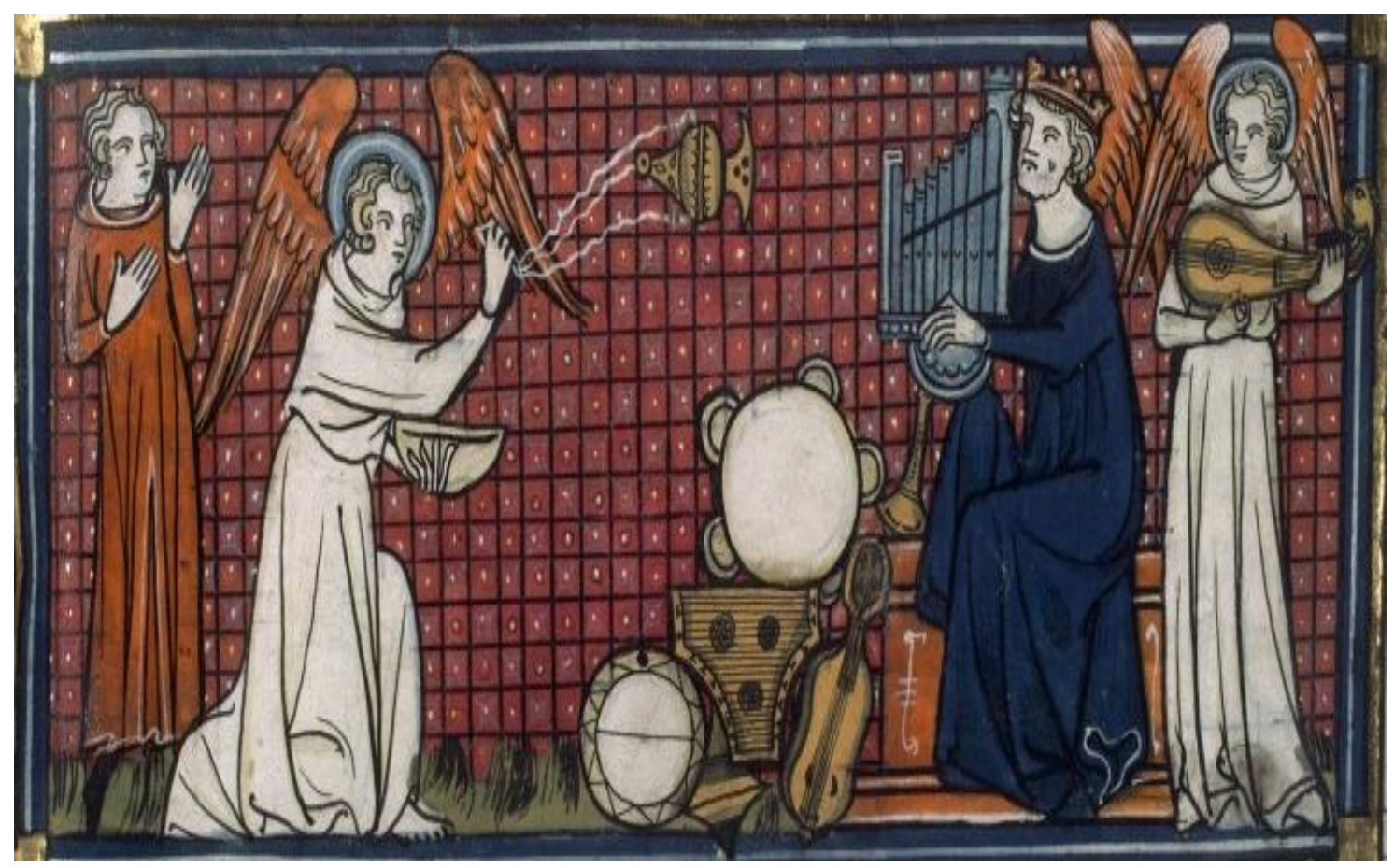

La primera miniatura representa la Chambre des beautés: su autor se distancia de la descripción que nos ofrece la novela, representando las estatuas que aparecen en la habitación como si fueran ángeles y siendo la habitación el paraíso. La interpretación es claramente cristiana, superponiéndola al carácter maravilloso y fantástico que refleja la descripción de Benoît de Sainte-Maure. Para comprender esta interpretación hay que tener en cuenta lo que expone Poirion: « pour bien interpréter le merveilleux d'une littérature comme celle du Moyen Age nous devons interroger la stratification des cultures, l'accumulation qui fait de l'histoire des mœurs, de la mentalité et de la spiritualité un processus d'évolution, sinon toujours continu et progressif du moins toujours en équilibre instable ${ }_{155}{ }^{»}$ 
En esta escena, observamos dos figuras que representan dos ángeles que bendicen al rey que se sitúa en la parte central de la escena; éste está caracterizado por la corona, todo ello situado en un ambiente casi celestial donde aparecen numerosos instrumentos de música. En la parte izquierda está presente un personaje con las manos en alto, él mismo maravillado ante la imagen que está viendo, lo que explícita lo maravilloso de la escena.

** Descripción de la chambre des beautés:

Estrumenz tint, genz e petiz,

E si n'en sot onc tant Daviz,

Quis fist e qui apareilla,

N'onques se bien ne les sona

Come l'image, sans desdit.

Iluec par ot si grant delit

Qu'il gigue, il harpe e sinphonie.

Rote, vïele e armonie,

Sautier, cinbales, tinpanon,

Monacorde, lyre, coron

Ice sunt les doze estrument

Que l'armonie esperitaus

$\mathrm{Ne}$ li curres celestiaus

N'est a oïr si deleitable.

Tot senble chose esperitable.

(V. 14775-14790) 
En la descripción de Benoît que corresponde a esta miniatura no hay referencia a los ángeles, sino que los personajes se designan como "automates musiciens". La miniatura expone los instrumentos descritos, creando una nueva caracterización de los personajes presentes en la habitación.

Así tal y como lo expone Harf-Lancner en su artículo: " l’indépendance de l'image s'affirme dans une miniature, l'une des plus curieuses du codex: la représentation picturale de la fameuse chambre des beautés (folio 141), la seule parmi tous les manuscrits du Roman de Troie. La description en est ici déplacée à la fin du roman. La rubrique qui introduit la description est fidèle au texte: “ $\mathrm{Ci}$ devise comment II demoiselles et II damoisiaus sont assis sur IIII piliers les buns contre les autres. Et tiennent l'une des damoiseles I miroer et l'autre joue de plusieurs jeus. Et l'un des danziaus ot en son chief couronne et tient plusieurs instruments. Et l'autre danziel tient I encenssier d'argent et les encensse ${ }_{156}{ }^{»}$ :

"Quis esguardot, ço li ert vis

Qu'angle fussent de Paradis"

(V. 14679-14680)

Presentando las figuras descritas en la Chambre des beautés como ángeles, influenciado por los últimos versos de Benoît de Sainte-Maure, el miniaturista filtra su representación a través de una óptica cristiana que le permite la reinterpretación de la escena para que ésta sea comprensible en la época de su recepción. De esta forma, se separa de lo escrito, tal y como hemos visto en otros casos anteriormente estudiados, con una intención clara de adaptar el texto a su contexto social y espiritual, dándole continuidad temporal.

156. Harf-Lancner, Laurence, «L'élaboration d'un cycle romanesque antique au XIIe siècle et sa mise en images: Le roman de Thèbes, Le roman de Troie et le Roman d'Énéas dans le manuscrit BN français 60 », Le monde du roman grec. Actes du colloque international tenu à l'École normale supérieure, Paris 17-19 décembre 1987, éd. Marie-Françoise Baslez, Philippe Hoffmann et Monique Trédé, Paris, Presses de l'École normale supérieure (Études de littérature ancienne, 4), 1992, p. 303-304. 
Folio 82 : "Ci devise la sisiesme Bataille de Troie la grant et de deux de Gresce, et y avoit .i. Sagittaire qui estoit moitié cheval et moitié homme".

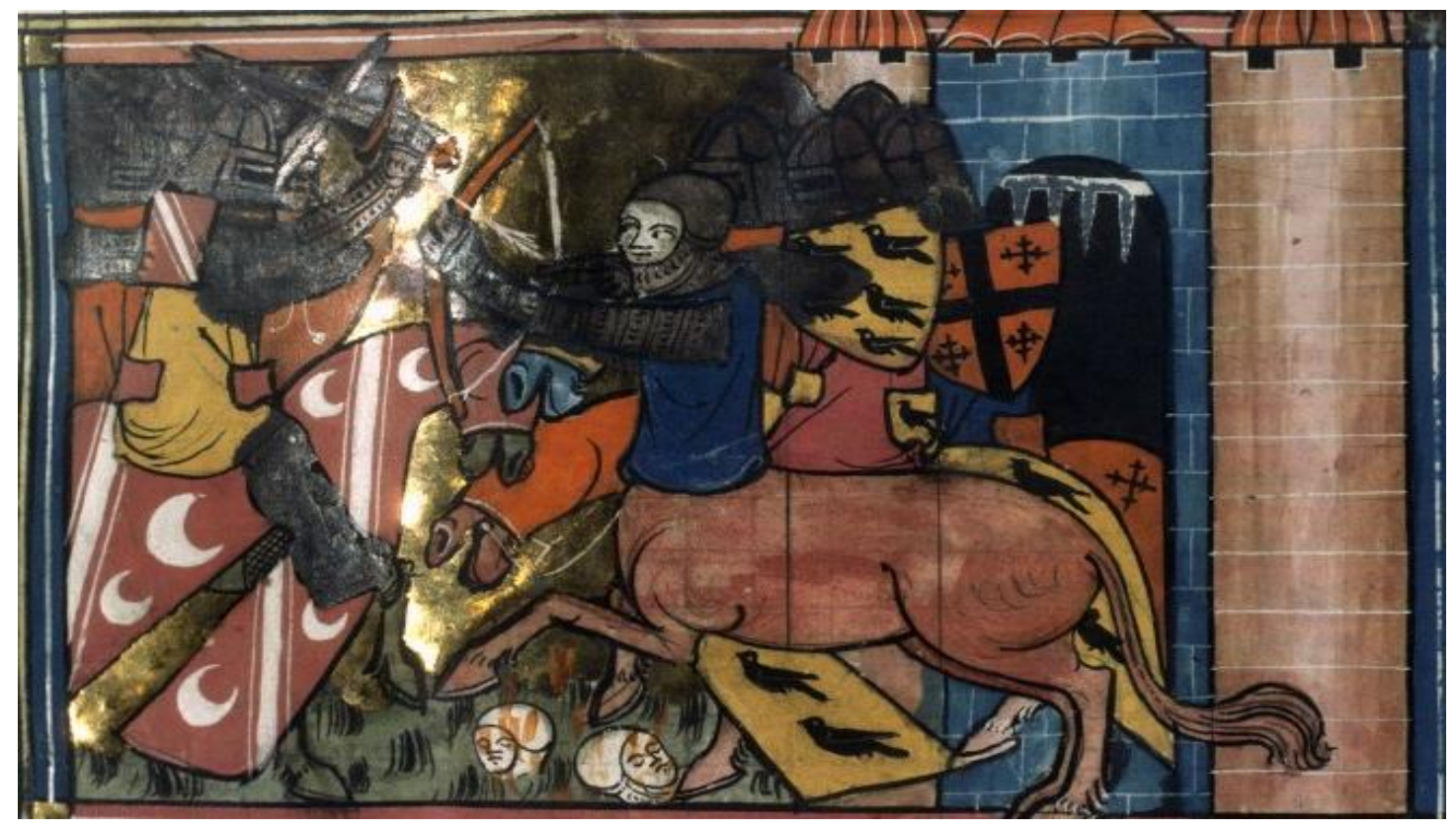

Esta miniatura hace referencia a un ser mitológico presente en el imaginario medieval. Se trata del Sagitario, animal de la tradición mítica clásica que representaba a un ser mitad hombre, mitad caballo, al que hemos aludido anteriormente. Esta miniatura representa la batalla 16; sin embargo en la novela de Benoît de Sainte-Maure, el Sagitario no aparece en esta batalla sino en una anterior: una vez más la fidelidad al texto escrito se rompe. Descrito como un auténtico monstruo por Benoît de SainteMaure, la miniatura lo representa como un simple caballero arquero centrándose en su fuerza en la batalla, más que en sus cualidades extraordinarias. Este personaje, tal y como expone Faral, es « un type assez isolé dans la littérature du moyen âge et que l'auteur semble avoir décrit en s'inspirant à la fois des traditions relatives à la faune de l'Orient et des représentations du zodiaque que les sculpteurs employaient volontiers comme motif de décoration depuis le $\mathrm{XI}^{\mathrm{e}}$ siècle $_{157}{ }$. 
E quant il veient l'averser

Qui a elz tret e les ocit,

N'i a un sol, grant ne petit,

Sans negune autre demorance

Li saïtaires tret a els:

A un sol tret en ocit deus

O treis, ce dit l'escriz, sovent,

En peti d'ore en ocit cent.

(V.12414-12424)

En estas dos miniaturas analizadas, podemos ver cómo el miniaturista adapta el texto a la mentalidad medieval, recreando ciertos pasajes de la novela y al mismo tiempo adaptándolos, sin variar la trama principal. Al examinar la primera miniatura hemos podido ver cómo la escena que reproduce está recreada bajo una óptica cristiana mitigando los elementos maravillosos que en el fragmento escrito aparecen de forma evidente. Por otra parte, la segunda miniatura de este apartado refleja un ser mitológico: el sagitario puede simbolizar las cualidades de un caballero medieval. En efecto, la presencia de este ser se puede explicar ya que encarna las cualidades propias de un buen guerrero en la batalla, tema que prolifera en Troie, y permite que esta representación no colisione con la mentalidad medieval y resulte creíble dentro del doble contexto, literario y pictórico. 


\section{CONCLUSIONES}

Al término del trabajo y tras haber analizado dos temas que funcionan como nexos temáticos entre las dos novelas estudiadas, lo primero que podemos decir es que se confirma el papel fundamental del Amor y la Guerra en la materia antigua. Por una parte, y desde el punto de vista textual, el énfasis en el tema amoroso, hasta ahora minimizado en la literatura épica anterior, se multiplica con la producción de un conjunto de tramas amorosas que nos han permitido no sólo ver lo que modifica el autor medieval con respecto a su modelo clásico sino también diferenciar las etapas que componen el proceso amoroso. Por otra parte, el tema de la guerra, y el análisis del prototipo de caballero, no solo nos evidencia la importancia del Roman d'Enéas como ejemplo de manual del buen caballero y el enfoque del personaje principal como prototipo de caballero ideal después de su viaje iniciático, sino que el análisis de dicho tema ha revelado el significado y la función de la supresión en el Roman de Troie de ciertos pasajes guerreros del modelo clásico para su adaptación al mundo medieval.

El recorrido temático que hemos efectuado a lo largo de la tesis nos ha permitido acercarnos a los textos y sus fuentes de inspiración. Hemos podido adentrarnos en el contexto del siglo XII, siglo de profundas reformas en la estructura económica y social de Occidente, del nacimiento de las ciudades y del desarrollo de la cultura dando lugar a un "renacimiento" que se presenta, como todo renacimiento, como un retorno a los "antiguos", mediante las traducciones de obras de la antigüedad clásica y la difusión de nuevas tradiciones. Los adaptadores, tal y como podemos llamar a los autores de estas dos novelas antiguas, ya que no nos ofrecen una traducción de las obras clásicas sino una adaptatio, han sabido utilizar sabiamente los procedimientos de la translatio para poder crear un espacio dentro de la obra con el fin de desarrollar su creatividad literaria, dotando a su texto de episodios que no aparecen en sus modelos. Así podemos exponer que «l'intellectuel du XII siècle est un professionnel, dont la 
principale est l'imitation des anciens. Tel est le sens de la fameuse phrase de Bernard de Chartres qui a eu un tel retentissement au Moyen Âge: Nous sommes des nains juchés sur des épaules de géants $158^{»}$.

Así, se ha contextualizado el análisis, en la segunda mitad del siglo XII y en el espacio anglonormando donde nacen las traducciones de obras de la Antigüedad latina dando a luz a lo que se conoce como la" materia de Roma". Esta práctica de adaptación de obras de la Antigüedad obedece a una demanda social, ya que solamente una minoría restringida, formada principalmente por clérigos, tiene acceso directo a la cultura en lengua latina. Pero, en estas traducciones/adaptaciones que son los "romans antiques", hemos podido ver cómo el mundo antiguo se transforma en un mundo feudal, donde los valores de la cortesía, de la proeza y del amor se superponen a las tramas adaptadas de los textos que sirvieron como fuente, y nos han servido como soporte para la comparación. La proeza guerrera y el amor, valores inminentemente caballerescos, siendo elementos propios de la novela antigua, se unen en estos textos para proponer una imagen diferente del héroe guerrero que hemos procurado despejar.

Por ello, en el primer capítulo toda la atención ha sido dedicada al análisis de los mitos y las tramas amorosas más destacadas en Troie y Enéas. Tras su examen se constata que Troie posee una variedad más extensa con 4 tramas amorosas frente a las 2 de Enéas. Ambas novelas demuestran las fases de la declaración amorosa y el papel creciente del caballero en el amor. La visión del amor y su tratamiento tan extenso supone una ruptura con la literatura épica anterior representada por el Cantar de Gesta, en donde la presencia del amor y los personajes femeninos ocupaban un segundo plano, dando toda la importancia al desarrollo épico en la narración.

Las tramas analizadas en Troie nos presentan las diferentes actitudes de los personajes masculinos y femeninos frente al amor, como en la primera, dedicada a Jasón y Medea, donde no sólo se nos presenta a un nuevo tipo de mujer: la hechicera, que adopta el papel fundamental, sino que evidencia los cambios que efectúa el escritor medieval al suprimir gran parte del mito clásico. Esta modificación, sin duda, ha permitido manifestar claramente las fases de la declaración amorosa, deliberadamente seleccionadas por Benoît de Sainte-Maure: el pensamiento, la mirada, el gesto, la palabra y la declaración presentes en todas las tramas analizadas. Estas cinco fases se 
convierten, en cinco elementos que conforman el esquema del desarrollo de una trama amorosa, tal y como se concebía en la época medieval, omitiéndose o minimizándose ciertas fases según la intención del autor.

Por otra parte, el enfoque de las tramas amorosas nos ha permitido ver no sólo la faceta de caballero protagonista a través de las numerosas pruebas a las que debe someterse para conseguir su objetivo, sino su comportamiento con respecto al amor, como en el caso de Jasón que se ve obligado a abandonar a Medea para cumplir con su deber de caballero, escena que se repetirá en la trama de Dido y Eneas. Jasón relega su faceta de hombre por la de caballero. Así, ya desde la primera trama amorosa, se hace patente la relación entre los dos temas desarrollados en el presente estudio.

La segunda trama amorosa centra su atención en Paris y Helena, donde se remarcan los cambios respecto al mito clásico así como las consecuencias del amorpasión que desemboca en la destrucción de Troya. Trama amorosa central, aparece envuelta en un halo de negatividad desde el primer momento, que se acentúa con los sentimientos de arrepentimiento y culpabilidad expuestos en el personaje de Helena. Mujer fatal y responsable de la destrucción de la ciudad, Helena es presentada como la verdadera culpable, omitiendo el mito del juicio de Paris, que para Benoît de SainteMaure carecerá de importancia. El destino trágico de los dos personajes prueba las consecuencias adversas del amor y la negatividad que conllevan los personajes femeninos en la Edad Media.

Si la primera trama de Troie nos muestra el abandono de la amada y la segunda la destrucción de una ciudad, la trama de Troilo y Briseida que ocupa el tercer lugar nos ha propuesto una nueva forma de desarrollo amoroso en la que se invierten los papeles de los personajes masculinos y femenino, y la aparición de un segundo personaje masculino, totalmente creado por el autor medieval, juega un papel destacado en el desenlace amoroso. Hemos podido ver cómo el papel principal está desempeñado por personajes masculinos, en los que se materializan los síntomas del amor, anteriormente sufridos por los personajes femeninos. Así, Briseida está relegada a un segundo plano y caracterizada negativamente. De esta forma aparece lo novedoso del papel principal del personaje masculino en el amor y ya no solamente su importancia guerrera enfatizada en las novelas épicas. 
Esta inversión de papeles también caracteriza la trama amorosa protagonizada por Aquiles y Policena. Poseedor de los valores guerreros, Aquiles sin embargo es ante todo un hombre enamorado, ocupando un papel primordial, caracterizado por el nexo temático establecido con el mito de Narciso que anuncia el trágico final de un guerrero, alcanzado como Medea por los síntomas del amor. Su funesto final, atestigua la negatividad del amor/pasión.De hecho, todas las tramas amorosas advierten de los peligros y del carácter dañino del amor tanto en los caballeros como en los personajes femeninos.

En cambio, si en Troie constatamos la unanimidad negativa del amor, hemos podido ver en el Roman d'Enéas una presentación positiva del amor, no antes de una exposición negativa en la primera trama, (Dido y Eneas). Con la segunda (Lavinia y Eneas) el autor se desmarca totalmente de este tratamiento.

Es que Enéas, no sólo nos transmite una doble valoración, positiva y negativa del amor, como hemos visto en el primer capítulo, sino también una tipología binaria de la mujer: Dido, marcada negativamente por su papel de reina, rol dedicado a los hombres, deja sus obligaciones por amor, lo que permite al autor la exposición de las debilidades femeninas. Todo lo contrario sucede con el personaje femenino de la trama amorosa de Lavinia y Eneas, que subraya los valores positivos del amor. El rol del personaje femenino principal marca, con Enéas, una ruptura con el tratamiento de la literatura épica anterior, siguiendo el tratamiento amoroso efectuado en Troie, donde en ciertas tramas el personaje femenino tiene un papel destacado por la toma de iniciativa. Con Lavinia, vemos un antes y un después en la historia literaria del personaje femenino.

Por otra parte, y desde el punto de vista literario, observamos la continuidad temática de la épica en el análisis del tema guerrero, objeto del segundo capítulo, que confirma no sólo la importancia de estas novelas como manual del buen caballero, al explicitarse los valores morales y sociales del caballero medieval representado en Enéas, sino también los cambios efectuados con respecto a sus modelos clásicos; cambios que afectan al tratamiento de la guerra, como también se han comprobado en el tratamiento amoroso. Los cánones analizados en Enéas son los exigidos para el caballero medieval, valores necesarios para formar la clase social que en el siglo XII se va a consolidar. 
En cuanto al análisis de los modelos clásicos, nos han proporcionado una visión de los cambios efectuados, tanto en la figura de los personajes como en la representación de los hechos bélicos. Si Enéas crea un modelo de caballero ideal que, a través del viaje iniciático, desvela su evolución y adquisición de valores sociales y morales, Troie nos presenta explícitamente las variaciones efectuadas en la translatio en el proceso de adaptación a la mentalidad en la que se elabora. En definitiva, revela cómo el género literario se convierte en la época medieval en un reflejo de su sociedad: «la poésie narrative n'est pas une simple caisse de résonance du folklore : elle reflète et façonne les valeurs de ceux par qui et pour qui elle est écrite. Les poètes ont fait des choix dans leur matière première, ils en ont éliminé certains aspects et en ont privilégié d'autres. $159^{\gg}$.

Además, el examen temático que ha determinado nuestro corpus, ha permitido por un lado crear un nexo de unión entre ambas novelas y, por otro lado, apreciar la gran labor de los dos autores medievales que, aun realizando grandes cambios como la eliminación parcial de la mitología, tal y como hemos podido constatar en los dos primeros capítulos de nuestro estudio, o al contrario con la ampliación de ciertos episodios, han logrado conservar la trama clásica, proporcionando una nueva visión a unas obras tan alejadas del Medievo.

En este sentido, siguiendo el nexo temático del Amor y la Guerra, el análisis de ciertas miniaturas del manuscrito $\mathrm{BN}$ fr60, del s. XV, nos ha permitido señalar el papel destacado del tema guerrero en las representaciones pictóricas frente al tema amoroso. Como hemos podido comprobar a lo largo de su estudio, las miniaturas reflejan no sólo su función estética y estilística respecto a la historia escrita sino también su función didáctica. Las miniaturas forman una parte indisociable del texto escrito en el que se encuentran, además de transmitir la interpretación personal y única de su autor.

Así, este estudio ha pretendido poner de relieve el valor y el mérito de dos autores medievales que no sólo crearon un lazo entre la literatura clásica y la literatura medieval, sino que lograron dar continuidad a unos textos que, gracias a la translatio, han tenido una larga expansión no sólo en su época sino también posteriormente. Es lo que hemos procurado confirmar en el tercer apartado, mediante el análisis del 
manuscrito BN fr60 que, no contento con cumplir una labor de transmisión e ilustración de las dos obras, efectúa a su vez otras variaciones que aportan una visión nueva y un nuevo enfoque. En efecto, a lo largo del análisis hemos podido comprobar las diferentes reinterpretaciones que realiza el miniaturista, observando los cambios efectuados frente a la novela escrita, sin por ello alejarse de la trama principal. La propia variación resulta significativa y enriquecedora para la comprensión del texto aumentando el valor de la miniatura como muestra ornamental y también y sobre todo como muestrario de las actitudes medievales frente al amor y la guerra. Su presencia en aquel manuscrito del s. XV es prueba de la difusión de estas dos novelas elaboradas durante el siglo XII y de su continua adaptación a la mentalidad de la época.

En este sentido, otro elemento, destacado a lo largo de los tres capítulos, es cómo el anacronismo se evidencia en este tercer capítulo más aún que en el resto, plasmado en las miniaturas de tema guerrero y amoroso. Hemos enfocado el anacronismo como muestra de la libertad en la interpretación del autor con relación a su texto y a las fuentes del texto. El miniaturista también contribuye a que el mundo antiguo se asimile a su mundo contemporáneo. Recordando aquí a Le Gentil ${ }_{160}$ se confirma que la Antigüedad clásica no es apreciada en lo que tiene de diferente sino que recibe inmediatamente muchas de las características propias del mundo medieval. Se ha podido comprobar pues en las miniaturas la función del anacronismo en las reinterpretación, bajo una óptica cristiana tal y como se perfilaba a lo largo de las novelas.

$\mathrm{Al}$ anacronismo va unida la presencia de lo maravilloso. Personajes, espacios y situaciones forman parte de esta nueva interpretación medieval que ocupa un lugar especial en el tercer capítulo, con el análisis de dos miniaturas pertenecientes a Troie y que acreditan su presencia. Estos dos episodios pictóricos resumen no sólo el tratamiento de lo maravilloso sino su pervivencia a lo largo de los años. Hemos destacado la reinterpretación de algunas escenas, que permite al miniaturista filtrar su adaptación a través de una óptica cristiana que acercaba la representación a la comprensión del lector: mitigándose los elementos mitológicos, bien a través de la óptica cristiana, bien a través de lo maravilloso. Esta última etapa de la tesis no ha tenido otro objetivo que el de establecer un nexo entre el texto y la imagen, más allá de 
la imagen pictórica, la que proviene de lo imaginario y se superpone a la escritura de la translatio, como testimonio de una transmisión: “c'est la transformation du récit en pensée, autrement dit le sens, qui importe: devoir de penser, qui prend en charge le devoir de mémoire-pensée partageable, transmissible, interprétable ${ }_{161}$ ". Quizá, esta afirmación del poeta Michel Deguy, que hemos deseado citar para actualizar la labor de aquellos escritores del Medievo, pueda dar continuidad al final de esta tesis hacia una profundización semántica del vínculo entre las ideas plasmadas y transmitidas en los textos de un género novelesco incipiente y las que el lector y la crítica se han ido haciendo a lo largo del tiempo.

161. Deguy, M., La fin dans le monde, Hermann, Paris, 2009, p. 9. 


\section{BIBLIOGRAFÍA}




\section{CORPUS}

-Enéas, roman du XII siècle, editado por J.J. SALVERDA DE GRAVE, 2 vol., Champion, C.F.M.A., Paris, 1985.

-Le roman de Troie de Benoît DE SAINTE-MAURE, traducido y editado por Emmanuèle BAUGARTNER y Françoise VIELLIARD, Le livre de Poche, Paris, 1998. -Manuscrito BN fr60, Paris, BNF.

-Le roman d'Enéas, édition critique d'après le manuscrit $\mathrm{BN}$ fr60 traducción presentación et notas Aimé Petit, Le livre de Poche, Paris, 2005.

\section{TRADUCCIONES}

-Le roman d'Enéas, trad. en francés moderno por M. Thiry STASSIN, Champion, Paris, 1985.

\section{OBRAS CONSULTADAS}

-APOLONIO DE RODAS, Argonáuticas, trad. y notas Mariano Valverde Sánchez, Madrid, Gredos, 1996.

-BODEL, J, La chanson de Saisnes, éd. F. MICHEL, Paris, 1839.

-CHAPELAIN, A., De amore, Barcelona, El festin de Esopo, 1985.

-La chanson de Roland / édition critique et trad. De Ian SHORT, Paris, Le livre de poche, 2010.

-La Ilíada latina; Diario de la Guerra de Troya de Dictis Cretense; Historia de la destrucción de Troya de Dares Frigio / introducciones, traducción y notas de $\mathrm{M}^{\mathrm{a}}$ Felisa DEL BARRIO VEGA y Vicente Cristóbal LÓPEZ, Madrid, Gredos, 2001. -EURÍPIDES, Medea, trad. Jose ALEMANY y BOLUFER, Madrid, Edaf, 1983. -HESIODO, Obras y fragmentos. Teogonía. Trabajos y días. Escudo. Fragmentos certamen. Trad. y notas de Aurelio PÉREZ JIMÉNEZ y Alfonso MARTÍNEZ DÍEZ, Madrid, Gredos, 1983.

-OVIDIO, Metamorfosis, Madrid, Alianza, 1995.

-VIRGILIO, Eneida, Madrid, Biblioteca Clásica de Gredos, 1992. 


\section{TEXTOS:}

-AKKARI, H., La déclaration amoureuse de l'hérö̈ne dans la chanson de geste ou Pour une autre poétique amoureuse in Bien Dire et Bien Aprandre Revue de Médiévistique, №15, Lille, CEMD, 1995.

-ANCINAS, B., «Art et Antiquité, l'influence de la littérature», in Percepción y Realidad, Estudios francófonos, Madrid, 2007.

-ARAMBURU, F., El héroe y el cosmos, Ediciones de la Universidad de Murcia, 1989.

-ARAMBURU, F., DESPRES, C., AGUIRIANO, B., BENITO, J., «Deux faces de la femme merveilleuse au Moyen Age: la magicienne et la fée», in Bien Dire et Bien Aprandre Revue de Médiévistique, nº12, Lille, CEMD, 1993.

-ARAMBURU, F., DESPRES, B., BENITO, J., «La déclaration amoureuse dans la littérature médiévale, in Bien Dire et Bien Aprandre Revue de Médiévistique, nº15, Lille, CEMD, 1993.

-BACKES, J.Ch., Le mythe d'Hélène, Clermont-Ferrand, Adosa, 1995.

-BADEL, P.Y., Introduction à la vie littéraire du Moyen Âge, Paris, Bordas, 1969.

-BARTHES, R., Mythologies, Paris, Seuil, 1957.

-Fragments d'un discours amoureux, Seuil, collection «Tel Quel»,1977.

-BAUMGARTNER, E., «Espace du texte, espace du manuscrit: les manuscrits du Lancelot-Graal», Ecritures II, Paris, 1985.

-Histoire de la littérature française, T.I: Moyen âge, 1050-1486, Paris, Bordas, 1987.

-BAUZÁ, H., F., Qué es un mito: una aproximación a la mitología clásica, Buenos Aires, Fondo de cultura económica, 2005.

-BECEIRO, I., De la Edad Media a la Moderna: Mujeres, educación y familia en el ámbito rural y urbano. Modelos de conducta y programas educativos para la aristocracia femenina siglos XII-XV, Málaga, Atenea estudios sobre la mujer, 1999.

-BEAUME, C., Naissance de la nation France, Paris, Gallimard, 1985.

-BILLER, G., Étude sur le style des premiers romans françaisen vers, Genève, Slatkine, 1974.

-BOESPLUGF, F., Las "Muy bellas horas" de Jean de France, duque de Berry: una obra maestra de finales de la Edad Media, Madrid, Casariego, 2001.

-BOLOGNA, G., Manuscritos y miniaturas: el libro antes de Gutenberg, Madrid, Anaya, 1988. 
-BRONZE, M., Le mythe d'Hélène, Bruxelles, Ousia, 2003

-BRUN, J., Platón y La Academia, Buenos Aires, Eudeba, 1965.

-BRUNEL, P., BELLENGER, Y., Histoire de la littérature française Vol. I: Du Moyen Âgeau XVIIIe siècle, Paris, Bordas, 2000.

-CARR- GOMM, S. Historia del arte: el lenguaje secreto de los símbolos y las figuras de la pintura universal, Barcelona, Blume, 2011.

-CENCILLO, L., Mito semántica y realidad, biblioteca de autores cristianos, Madrid, 1970.

-CERRRITO, S., “Les métamorphoses de Médée au Moyen Âge”, in Bien Dire et Bien Aprandre Revue de Médiévistique, n²4, Lille, CEMD, 2005.

-CORTÁZAR, J., Bestiario, Buenos Aires, Editorial Sudamericana, 1978.

-CLIER-COlOMBANI, F., La fée Mélusine au Moyen Âge, Paris, Le léopard d'or, 1991.

-«Prologues en images dans l'Ovide Moralisé», in Bien Dire et Bien Aprandre Revue de Médiévistique, nº19, Lille, CEMD, 2001.

-CROIZY-NAQUET, C., “ le portrait d'Hector dans le Roman de Troie de Benoît de Sainte-Maure", in Bien Dire et Bien Aprandre Revue de Médiévistique n¹4, Lille, CEMD, 1996.

-CROUZET, M., Espaces romanesques, Picardie, PUF, 1982.

-DE BRUYNE, E., Études d'esthétique médiévale, Genève, Statkine, 1946, vol II.

-DEGUY, M., La fin dans le monde, Hermann, Paris, 2009.

-DEREMETZ, A., «Virgile et le labyrinthe du texte», in Uranie $\mathrm{n}^{\circ} 3$, Association « Mythes et Littératures», Arras, Lille, 1993.

-DESPRES- CAUBRIERE, C., «L'enjeu triangulaire de la trame romanesque du Roman d'Enéas» in Cédille n ${ }^{\circ}$ 9, 2014.

-DUBY, G., L'an mil, Paris, Juillard, 1967.

-Los tres órdenes o lo imaginario del feudalismo, Barcelona, Petrel, 1980.

-El caballero, la mujer y el cura, Madrid, Taurus, 1982.

-Europa en la Edad Media, Barcelona, Paidós, 1986.

-Le moyen âge: De Hugues Capet à Jeanne d'arc, 987-1460, Paris, Hachette, 1987.

-El amor en la Edad Media y otros ensayos versión española de Ricardo Antola, Madrid, Alianza, 1990.

-Histoire des femmes en Occident: Le Moyen Âge, Paris, Plon, 1991.

-La época de las catedrales:arte y sociedad 980-1420, Madrid, Cátedra, 1993. 
-L'art et la société: Moyen Âge-XX siècle, Paris, Gallimard, 2002.

-DUMÉZIL, G., Mythe et épopée, París, Gallimard, 1986

-DZUROVA, A., Miniatura bizantina, Barcelona, Lunwerg, 2001.

-EIGELDINGER, M., Lumières du mythe, Paris, PUF, 1983.

-ELIADE, M., Aspects du mythe, Paris, Gallimard, 1963.

-Lo sagrado y lo profano, Madrid, Ediciones Guadarrama, 1973.

-FABRE-SERRIS, J., Rome, L'Arcadie et la mer des Argonautes, Villeneuve d'Ascq, Presses Universitaires du Septentrion, 2008.

-FARAL, E., Arts poétiques du XII et du XIIIsiècle: recherches et documents sur la technique littéraire du Moyen Âge, Genève, Slatkine, 1982.

-Recherches sur les sources latines des contes et romans courtois du Moyen Âge, Paris, Slatkine Reprints, 1983.

-FOURNIVAL, R., Bestiario de amor, Madrid, Miraguano, 1990.

-FLORI, J., L'essor de la chevalerie, Genève, Droz, 1986.

-FRAPPIER, J., La poésie lyrique en France aux XII et XIII siècles, Paris, S.E.D.E.S, 1949.

-Études d'histoire et critique littéraire: du moyen âge à la renaissance, Paris, Honoré Champion, 1982.

-GARCÍA, Fr., «El león» in Revista digital de iconografía medieval, vol.II, Madrid, 2009.

-GALLAIS, L'imaginaire d'un romancier francais de la fin du XIIe siècle: description raisonnée, comparée, Amsterdam, Rodopi, 1988.

-GALLARDO LÓPEZ, M., D., Manual de mitología clásica, Madrid, Ediciones clásicas, 1995.

-GARNIER, F., Le langage de l'image au moyen âge: signification et grammaire des gestes, Tomo1 y Tomo 2, Paris, Le léopard d'or, 1982.

-GAVILÁN, E., Entre la historia y el mito: el tiempo en Wagner, Madrid, Akal, 2013.

-GENETTE, G., Palimpsestes, Paris, Seuil, 1982.

-GONZÁleZ DE ZÁRATE, J., M., Mitología e historia del Arte. 1, De Caos y su herencia ; los Uránidas, Madrid, Encuentro, 2012.

-GOUREVITCH, A., Les catégories de la culture médiévale, Paris, Gallimard, 1989.

-GUYÉNOT, L., La mort féerique: Anthropologie médiévale du merveilleux (XII -XV siècle), Paris, Gallimard, 2011. 
-GLASMAN, G., Fabulosaas criaturas de la mitología clásica, Arganda del Rey, Edimat libros, 2006.

-GRIMAL, P., Dictionnaire de la mythologie grecque et romaine / Pierre Grimal ; préface de Charles Picard, Paris, PUF, 1994.

-GRISWARD, J., H., Archéologie de l'épopée médiévale, structures trifonctionnelles dans le cycle des Narbonnais, Paris, Payot, 1981.

-HARF-LANCNER, L., «Les manuscrits enluminés de l'Énéas: assonances et dissonances du texte et de l'image», L'image au Moyen Âge. Actes du colloque d'Amiens, 19-23 mars 1986, Amiens, Centre d'études médiévales, Université de Picardie (Wodan, 15. Serie 3: Tagungsbände und Sammelschriften, 5), 1992.

-«L'élaboration d'un cycle romanesque antique au XIIe siècle et sa mise en images: Le roman de Thèbes, Le roman de Troie et Le Roman d'Énéas dans le manuscrit BN français $60 »$, Le monde du roman grec. Actes du colloque international tenu à l'École normale supérieure, Paris 17-19 décembre 1987, éd. Marie-Françoise Baslez, Philippe Hoffmann et Monique Trédé, Paris, Presses de l'École normale supérieure (Études de littérature ancienne, 4), 1992.

-Le monde des fées dans l'occident médiéval, Paris, Hachette, 2003.

-HARF-LANCNER, L., MATHEY-MAILLE, L., SZKILNIK, M., Ovide méthamorphose. Les lecteurs médiévaux d'Ovide, Paris, Presses Sorbonne, 2009.

-HAUCOURT, G., La vie au Moyen Âge, Paris, PUF, 1968.

-HUCHET, J.C., Le roman médiéval, Paris, PUF, 1984.

-HUMBERT, J., Mitología griega y romana, Barcelona, Gustavo Gili, 1993.

-JAFFÉ, A., The mythe of meaning, Baltimore, Daimon, 1975.

-JUNG, M. R., La légende de Troie en France au Moyen Âge, Basel und Tübingen: Francke, 1996.

-LEFAY-TOURY, Marie-Noëlle, La tentation du suicide dans le roman français du XII siècle, Paris, Honoré Champion, 1979.

-Les manuscripts François de la Bibliothèque du roi, Vol. 1, Paulin Paris, Techener, 1836.

-LE GENTIL, P., La littérature française du Moyen Âge, Paris, Armand Colin, 1968.

-LE GOFF, J., Les intellectuels au moyen âge, Paris, Seuil, 1957.

-L’imaginaire médiéval, Paris, Gallimard, 1985.

-Histoire et mémoire, Paris, Gallimard, 1988.

-El nacimiento del purgatorio, Madrid, Taurus, 1989. 
-Héros du Moyen Âge, le saint et le roi, France, Gallimard, 2004.

-Héros et merveilles du Moyen Âge, Paris, Seuil, 2005.

-Un autre Moyen Âge, Paris, Gallimard, 2006.

-Lo maravilloso y lo cotidiano en el Occidente medieval, Barcelona, Gedisa, 2008.

-Una larga Edad Media, Barcelona, Paidós, 2008.

-L'Europe est-elle née au Moyen âge, Barcelona, Crítica, 2011.

-LECOY DE LA MARCHÉ, A., Les manuscrits et la miniature par Lecoy de la Marché, Paris, A. Quentin, 1884.

-LE RIDER, P. Le chevalier dans le conte du Graal de Chrétien de Troyes, Paris, Société d'édition d'enseignement, 1978.

-LÉVI-STRAUSS, Cl., Mito y significado, Madrid, Alianza, 1987.

-LEWIS, C. S., La imagen del mundo, Barcelona, Antoni Bosch Editor, 1987.

-LIMET, H. et RIES, J., Le mythe: son langage et son message: actes du colloque de Liège et Louvain-La-Neuve / édités par H. LIMET et J. RIES, Louvain-La-Neuve: Centre d'Histoire des Religions, 1983.

-LOGIÉ, PH., "Le traitement du livre VI de l'Énéide dans l'Énéas: propositions méthodologiques" in Bien Dire et Bien Aprandre Revue de Médiévistique n¹4, Lille, CEMD, 1996.

-MALAXECHEVERRÍA I., Bestiario medieval, Madrid, Siruela, 2000.

-MALINOWSKI, B., Myth in primitive psychology, London, Norton, 1926.

-MANDEL, G., Miniatura románica y gótica, Barcelona, Vincens Vives, 1967.

-MARTÍNEZ- FALERO, L. M., Narciso en España de los orígenes a la desmitificación del mito, Madrid, Ediciones clásicas, 2011.

-MARTÍNEZ DE LA TORRE, C., Mitología clásica e iconografía cristiana, Madrid, Editorial Universitaria Ramón Areces, 2010.

-MOLPECERES ARNÁIZ, S., Mito persuasivo y mito literario: bases para un análisis retórico-mítico del discurso, Valladolid, Ediciones Universidad de Valladolid, 2014. -MONTOYA, J., El libro historiado, significado socio-político en los siglos XIII-XIV, Madrid, Sílex, 2005.

-MONFRIN, J., "Les translations vernaculaires de Virgile au Moyen Age", dans Lectures médiévales de Virgile, Rome et Paris, De Boccard, 1985.

-MORA, F., « Sources de l'Enéas : la tradition exégétique et le modèle épique latin », dans Relire le Roman d'Enéas, J. Dufournet éd., Paris, Champion, 1985 (collection Unichamp). 
- A la recherche du stylus gravis: ébauche d'enquête sur la descriptio épique du ler au XII siècle », dans Styles et valeurs. Pour une histoire de l'art littéraire au Moyen-Age, D. Poirion éd., Paris, SEDES, 1990.

-«Byzance et l'Occident dans le Roman d'Enéas: imaginaire historique et propagande politique », dans Histoire et littérature au Moyen-Age (Actes du colloque d'Amiens de mars 1985), D. Buschinger éd., Göppingen, Kümmerle Verlag, 1991.

-«De Bernard Silvestre à Chrétien de Troyes : résurgences des Enfers virgiliens au XII ${ }^{\circ}$ siècle », dans Voyages dans l'ici-bas et dans l'au-delà au Moyen-Age (Diesseits- und Jenseitsreisen im Mittelalter), W. D. Lange éd., Bonn-Berlin, Bouvier Verlag, 1992.

-L'Enéide médiévale et la naissance du roman, Paris, PUF, 1994.

-Dictionnaire Universel des Littératures, sous la direction de B. Didier et M. Zink (partie «Moyen-Age français », articles Romans antiques et Benoît de Sainte-Maure), Paris, PUF, 1994.

-«La fabula antique comme matrice des premières mises en roman : l'exemple de Guillaume d'Angleterre », dans L'Hostellerie de Pensée. Etudes sur l'art littéraire au Moyen-Age offertes à D. Poirion par ses anciens élèves, Paris, Presses de la Sorbonne, 1995.

-«Dudon de Saint-Quentin et ses deux traducteurs français, Wace et Benoît », dans Dudone di San Quintino, a cura di P. Gatti et A. Degl'Innocenti, Trente, 1995.

-De l'Énéide à l'Énéas: le traducteur médiéval à la recherche d'une nouvelle stylistique, in Bien Dire et Bien Aprandre Revue de Médiévistique nº14, Lille, CEMD, 1996.

- « Mythe troyen et histoire thébaine : le manuscrit S du Roman de Thèbes », dans Entre fiction et histoire : Troie et Rome au Moyen-Age, E. Baumgartner et L. Harf-Lancner éd., Paris, Presses de la Sorbonne Nouvelle, 1997.

-Le Moyen Age au miroir du XIXe siècle, ouvrage coordonné par L. Kendrick, F. Mora et M. Reid, Paris, L'Harmattan, 2003 (actes d'un colloque tenu à l'Université de Versailles - Saint Quentin-en-Yvelines les 22 et 23 juin 2000).

-Du roman courtois au roman baroque, ouvrage publié sous la direction d' E. Bury et F. Mora, Paris, Les Belles-Lettres, 2004 (actes d'un colloque tenu à l'Université de Versailles - Saint Quentin-en-Yvelines du 2 au 5 juillet 2002).

-« La Sibylle séductrice dans les romans en prose du XIII ${ }^{\circ}$ siècle : une Sibylle parodique ? », dans La Sibylle, parole et représentation, M. Bouquet et F. Morzadec éd., Presses Universitaires de Rennes, coll. "Interférences", 2004. 
-«La réception de l'Antiquité au Moyen Age », dans Perspectives Médiévales. Trente ans de recherches en langues et en littératures médiévales (numéro jubilaire), J. R. Valette éd., 2005.

-«Metre en romanz »:les romans d'antiquité du XIIe siècle et leur postérité (XIIIe-XIVe siècle), Paris : Champion, coll. « Moyen Âge - Outils et Synthèses », 2008.

-«Crime et châtiment dans l'Iliade de Joseph d'Exeter », dans B. RIBÉMONT (dir.), Crimes et châtiments dans la chanson de geste, Paris: Klincksieck, 2008.

-«Le mythe des géants et la"renaissance" du XIIe siècle », dans J. P. AYGON, C. BONNET et C. NOACCO (dir.), La mythologie de l'Antiquité à la Modernité. Appropriation, adaptation, détournement, Rennes: Presses Universitaires de Rennes, coll. «Interférences », 2009.

- «Gérard de Nevers, jongleur et chevalier : un modèle pour la cour dans le Roman de la Violette ? ", dans A. CORBELLARI, Y. FOEHR-JANSSENS, J. Cl. MÜHLETHALER, J. Y. TILLIETTE et B. WAHLEN (dir.), Mythes à la cour, mythes pour la cour (Courtly Mythologies), actes du XIIe Congrès de l'ICLS (juillet-août 2007, Lausanne-Genève), Genève : Droz, 2010.

-«L'utilisation du commentaire de Servius dans le Roman d'Eneas », dans Servius et sa réception de l'Antiquité à la Renaissance, M. Bouquet et B. Méniel dir., Presses Universitaires de Rennes, coll. «Interférences », 2011

-«Ab ovo. Les manuscrits de l'Ovide Moralisé: naissance et survie d'un texte », article conçu et rédigé en collaboration avec Marylène POSSAMAÏ-PÉREZ, Thomas STÄDTLER et Richard TRACHSLER, Romance Philology, 65, 2011.

-«Ville allégorique ou ville rêvée? Troie chez Joseph d'Exeter et Benoît de SainteMaure », dans Ch. IMBERT et Ph. MAUPEU (dir.), Le paysage allégorique, entre image mentale et pays transfiguré, Rennes: Presses Universitaires de Rennes, coll. « Interférences », 2011.

-«D'un manuscrit à l'autre: quelques réflexions sur les éditions de Piramus et Tisbé », dans A. FAEMS, V. MINET-MAHY et C. Van COOLPUT-STORMS (dir.), Les translations d'Ovide au Moyen Âge, Louvain-la-Neuve: Publications de l'Institut d'Études Médiévales de l'Université Catholique de Louvain, coll. «Textes, Études, Congrès », 2011.

-«Y a-t-il des circonstances atténuantes dans l'Iliade de Joseph d'Exeter et dans le Waltharius? », dans La faute dans l'épopée médiévale. Ambiguïté du jugement, B. Ribémont dir., Rennes, Presses Universitaires de Rennes, coll. «Interférences », 2012. 
-«S'approprier la langue de l'autre. Jeux sur l'onomastique et translatio studii chez Hue de Rotelande et Aimon de Varennes », dans Langue de l'autre, langue de l'auteur. Affirmation d'une identité linguistique et littéraire aux XIIe et XVIe siècles, M.-S. Masse et A.-P. PoueyMounou éd., Genève, Droz, 2012.

- «Des translations différentes: les versions manuscrites du Roman d'Eneas, du XIIe au XIVe siècle », dans Translatio: traduire et adapter les Anciens, C. Bonnet et F. Bouchet éd., Paris, Classiques Garnier, 2013.

-«Virgil in Medieval French literature » à paraître dans The Virgil Encyclopedia mise en chantier par Jan Ziolkowski et Richard Thomas à l'Université de Harvard (manuscrit remis en novembre 2009; publication prévue chez Wiley-Blackwell fin 2013 - début 2014).

-NIETZSCHE, La naissance de la tragédie trad de G. bianquis, Gallimard, Paris, 1940. -PÄCHT, O., La miniatura medieval, una introducción, Madrid, Alianza, 1987.

-PAYEN, J. CH., Le motif du repentir dans la littérature française médiévale, Genève, Librairie Droz, 1967.

-PEDROSA, J., M., Bestiario:antropología y simbolismo animal, Madrid, Grupo Medusa Ediciones, 2002.

-PERÉZ-RIOJA, J.A., Diccionario de símbolos y mitos, Madrid, Tecnos, 1962.

-PETIT, A., Naissance du roman. Les techniques littéraires dans les romans du XII siècle. T.II, Paris, Champion, 1985.

- «Les avatars du Roman d'Enéas dans le manuscrit du XIVe siècle » in Bien Dire et Bien Aprandre Revue de Médiévistique nº14, Lille, CEMD, 1996.

-L'Anachronisme dans les romans antiques du XII siècle, Honoré Champion, Paris, 2002.

-«Dido dans le Roman d'Enéas» in Bien Dire et Bien Aprandre Revue de Médiévistique $\mathrm{n}^{\circ}$ 24, Lille, CEMD, 2006.

-POIANA, P., Figures et style: concepts esthétiques dans la théorie du discours de Gérard Genette in Littérature, nº 95, 1994.

-POIRION, D., “De l'Énéide à l'Enéas, mythologie et moralisation” in Cahiers de Civilisation médiévale, ${ }^{\circ}$ XIX, Poitiers, 1976.

-Le merveilleux dans la littérature française du moyen âge, Paris, Presses Universitaires de France, 1982.

-Précis de littérature française du Moyen Âge, Paris, PUF, 1983.

-Résurgences: mythe et littérature à l'âge du symbole (XIIe siècle), Paris, PUF, 1985. 
-POSSAMAÏ-PERÉZ, “Les métamorphoses d'Ovide : une adaptation du début du XIVe siècle" in Bien Dire et Bien Aprandre Revue de Médiévistique nº14, Lille, CEMD, 1996. -PRADO, J., Historia de la literatura francesa. “Edad Media”, Madrid, Cátedra, 1994. -PROGOFF, I., La psicología de Jung y su significación social, Buenos Aires, Paidós, 1967.

-RAYNAUD DE LAGE, G., Les premiers romans français et autres études littéraires et linguistiques, Genève, Droz, 1975.

-RYCHNER, J., La chanson de geste. Essai sur l'art épique des jongleurs, Genève, Droz, 1955.

-RUIZ DE ELVIRA, A., Mitología clásica, Madrid, Editorial Gredos, 2011.

-SAUCIUC, V., Deux poèmes français de Narcisse adaptés d'Ovide, Paris, Mélanges de l'école roumaine en France, 1923.

-SEEMANN, O., Mitología clásica ilustrada, Barcelona, Vergara, 1958.

-SMEYERS, M., Typologie des sources du Moyen âge. La miniature, Brepols, Turnhout, 1974.

-L'art de la miniature flamande: du VIII au XVI siècle, trad. de Monique Verboomen, Tournai (Belgique), La renaissance du livre, 1998.

-STRAUSS, L., Antropología estructural, Buenos Aires, Eudeba, 1969.

-TARANILLA DE LA VARGA, C. J., Breve historia del arte, Madrid, Nowtilus, 2014. -VINCENSINI, J.J., Pensée mythique et narrations médiévales, Paris, Honoré Champion, 1996.

-WADE LABARGE, M., La mujer en la Edad Media, Madrid, Nerea, 2003.

-WILliAMS, J., La miniatura española en la Alta Edad Media, Madrid, Casariego, 1987.

-WILMOTE, M., Origines du roman en France, Genève, Slatkine, 1974.

-WINCKELMANN, J., J., Historia del arte de la antigüedad / Johanm Joachim Winckelmann, traducción de Joaquin Chamorro Miel, Madrid, Akal, 2011.

-ZINK, M., «Une mutation de la conscience littéraire: le langage romanesque à travers des exemples français du XIIe siècle» in Cahier de civilisation médiévale, t. XXIV.

-Littérature française du Moyen Âge, Paris, PUF, 1992.

-Introduction à la littérature française du Moyen Âge, Paris, le livre de poche, 1993.

-«Une mutation de la conscience littéraire: Le langage romanesque à travers des exemples français du XIIe siècle» dans Cahier de civilisation médiévale, T. XXIV, No1, janvier-mars 1981. 
-ZUMTHOR, P., “Topique et tradition" in Poétique n7, 1971.

-Essaie de poétique médiévale, Paris, Seuil, 1972.

\section{PÁGINAS WEB:}

-http: // www.rae.es /rae html. 


\section{ÍNDICE}

$\begin{array}{ll}\text { INTRODUCCIÓN } & 7\end{array}$

APROXIMACIÓN DEFINITORIA DEL MITO 9

LAS REESCRITURAS DEL MITO EN EL TEXTO MEDIEVAL 14

I. EL AMOR EN EL ROMAN DE TROIE Y EN EL ROMAN D'ENÉAS 23

INTRODUCCIÓN 25

1.1 EL AMOR EN EL ROMAN DE TROIE: ANÁLISIS DE ELEMENTOS MITOLÓGICOS PRESENTES EN LAS TRAMAS AMOROSAS 25

1.1.1. JASÓN Y MEDEA O LA TRAICIÓN DE UNA PROMESA. MITO MEDIEVAL Y MITO CLÁSICO 29

1.1.2. ANÁLISIS DE LA TRAMA AMOROSA JASÓN-MEDEA 36

1.1.3. MEDEA: LA MUJER Y EL AMOR 46

1.1.4. PARIS Y HELENA: El AMOR PROHIBIDO 50

1.1.5. HELENA O EL AMOR CULPABLE 60

1.1.6. TROILO Y BRISEIDA 69

1.1.7. AQUILES, EL NUEVO NARCISO 76

APÉNDICE 84

1.2. EL AMOR EN EL ROMAN D'ENÉAS: ANÁLISIS DE ELEMENTOS MITOLÓGICOS PRESENTES EN LAS TRAMAS AMOROSAS 89

1.2.1. DICOTOMÍA FEMENINA 89

1.2.2. DIDO Y ENEAS 97

1.2.3. LAVINIA Y ENEAS 105

II. LA GUERRA EN EL ROMAN D' ENÉAS Y EL ROMAN DE TROIE: ESTUDIO COMPARATIVO DE LAS NOVELAS MEDIEVALES Y SUS MODELOS CLÁSICOS 111

INTRODUCCIÓN 113

2.1. ENÉAS Y LA ENEIDA: CAMBIOS REALIZADOS CON RESPECTO AL MODELO CLÁSICO 116

2.1.1. El HÉROE EN ENÉAS Y LA ENEIDA 124

2.1.2. HUIDA DE TROYA 135

2.1.3. EL DESCENSO A LOS INFIERNOS 140

2.1.4. FUNDACIÓN DE SU NUEVA PATRIA 141

2.2. EL ROMAN DE TROIE Y SUS MODELOS CLÁSICOS: 152 
2.2.1. CAMBIOS REALIZADOS CON RESPECTO AL MODELO CLÁSICO 153

III. ANÁLISIS DEL MANUSCRITO ILUMINADO BN fr 60:

REPRESENTACIÓN DEL AMOR Y LA GUERRA A TRAVÉS DE SUS MINIATURAS

INTRODUCCIÓN

CORPUS MINIATURAS: EL AMOR Y LA GUERRA

3.1 LA MINIATURA EN FRANCIA

3.2. LAS MINIATURAS INICIALES DE ENÉAS Y TROIE

3.2.1. PÁGINA INICIAL DE ENÉAS:

3.2.2. PÁGINA INICIAL DE TROIE:

3.3. EL AMOR EN LAS MINIATURAS DEL ROMAN D'ENÉAS 222

3.4. EL AMOR EN LAS MINIATURAS DEL ROMAN DE TROIE 227

3.5. LA GUERRA EN LAS MINIATURAS DEL ROMAN D'ENÉAS. 235

3.6. LA GUERRA EN LAS MINIATURAS DEL ROMAN DE TROIE 252

3.7. LA REPRESENTACIÓN DE LO MARAVILLOSO EN LAS MINIATURAS

DE RICHARD DE MONTBASTON:

CONCLUSIONES: 